\author{
Universidade de São Paulo \\ Instituto de Física \\ Faculdade de Educação
}

\title{
As intervenções do professor e o processo grupal nas aulas de Física: uma análise à luz da teoria dos grupos operativos
}

\author{
Glauco S. F. da Silva
}

Orientador: Prof. Dr. Alberto Villani

Dissertação de mestrado apresentada ao Instituto de Física, e a Faculdade de Educação da Universidade de São Paulo, para a obtenção do título de Mestre em Ensino de Ciências.

São Paulo

2008 


\section{FICHA CATALOGRÁFICA \\ Preparada pelo Serviço de Biblioteca e Informação do Instituto de Física da Universidade de São Paulo}

Silva, Glauco dos Santos Ferreira da

As intervenções do professor e o processo grupal nas aulas de Física: uma análise à luz da teoria dos grupos operativos - São Paulo, 2008.

Dissertação (Mestrado) - Universidade de São Paulo. Instituto de Física - Depto. de Física Aplicada

Orientador: Prof. Dr. Alberto Villani

Área de Concentração: Ensino de Ciências

Unitermos: 1. Ensino; 2. Física; 3. Processo Grupal;

4. Grupo operativo.

USP/IF/SBI-008/2008 


\author{
Universidade de São Paulo \\ Instituto de Física \\ Faculdade de Educação
}

\title{
As intervenções do professor e o processo grupal nas aulas de Física: uma análise à luz da teoria dos grupos operativos
}

\author{
Glauco S. F. da Silva
}

Orientador: Prof. Dr. Alberto Villani

Dissertação de mestrado apresentada ao Instituto de Física, e a Faculdade de Educação da Universidade de São Paulo, para a obtenção do título de Mestre em Ensino de Ciências.

\section{BANCA EXAMINADORA}

Prof. Dr. Alberto Villani- IFUSP

Prof. Dr. Cristiano Rodrigues de Mattos- IFUSP

Profa. Dr. Maria Inês A. Fernandes- IPUSP 
A Jorge, Cirley,

Glauber, Gisela e George

"Os opostos se distraem, os dispostos se atraem" 


\section{AgRADECIMENTOS:}

A Deus, pela sua infinita bondade que em si mesmo constitui-se como um grupo: uno e trino;

Aos meus pais, Jorge e Cirley, e meus irmãos, Glauber, Gisela e George, por sempre apoiarem meus projetos de vida, incluso este, com incentivos ao longo dos anos;

Aos meus familiares, pelo apoio e incentivos;

Ao Villani, pela confiança em mim depositada e pela sua presença amiga;

Aos professores do exame de qualificação: Profa. Dra. Maria Helena Ciampone e Profa. Dra. Elisabeth Barollli, pela leitura crítica e sugestões;

Aos professores desta banca avaliadora, Profa Maria Inês A. Fernandes e Prof. Cristiano Mattos, pela leitura detalhada deste trabalho e pelas discussões que surgiram a partir das questões por eles colocadas;

Ao Pe. João Sérgio, pela amizade e apoio ao longo desses anos e à Meyre, pela sua preocupação e generosidade para comigo;

\section{Aos amigos:}

De Petrópolis e Juiz de Fora, que mesmo distantes, permaneceram sempre em unidade à minha caminhada;

Do EJC, EAC e Igreja do Calvário; PUR; GPP; e dos Focolares (Árvore), pela acolhida, carinho, apoio e incentivos nesses anos em São Paulo;

Do 605 do CRUSP: Adrylaine, Hudson, Esdras, Rodrigo, Litzy, Matheus e Maraca. Pessoas com as quais aprendi um pouco mais o sentido da vida em grupo; E os amigos: Lu Caixeta, Sylvia, Michela, Maria Ana, Milton, Lailton;

Do corredor de ensino: Ailton, Darci, Camila, Leo, Lia, José Guilherme, Estevam e Maxiwell, Neusinha, Soraya, Wilson, Elifas, Renatinha, Cris, Ivanilda, Soninha, Anne, Fábio, Mário, Gisele, Lu Faustino ("Creidy”), Marcília, Ligia, Ivan, Jack, André, Francisco, Breno, Fred, Roseline, Eraldo, Ricardo Rech, Maria Regina, Nelson, Cristiano, Nelson e Yassuko;

Do grupo de pesquisa: Lu, Beth, Helô, Joana, Dora, Maísa, Luciano, Diógenes, Verônica, Juarez, Ana, Marlene, Mariza, Marco Aurélio, Isabel, Valéria, Luis Augusto.

do trabalho;

Do CEFET e do Colégio Raposo Tavares, pelos incentivos nos meses finais

Do Instituto Estadual de Juiz de Fora, Nadege, Regina, Taninha e Paulo, pelo apoio no início do Mestrado, ajudando-me com os trâmites burocráticos do IEE; pesquisa;

Ao professor, aos alunos e à Escola, por permitirem o espaço para

Ao CNPq, pelo apoio financeiro. 


\section{RESUMO}

SILVA, G. S. F. As intervenções do professor e o processo grupal nas aulas de Física: uma análise à luz da teoria dos grupos operativos. 241f. Dissertação (Mestrado em Ensino de Ciências-modalidade Física)-Instituto de Física/ Faculdade de Educação, Universidade de São Paulo, São Paulo, 2008.

Quando alunos, convocados pelo professor, se reúnem em grupos numa sala de aula, inicia-se uma construção de relações interpessoais, envolvendo alunos e professor, que influenciam fortemente o processo grupal. O foco do nosso trabalho está neste processo, ou seja, em como um grupo de ensino-aprendizagem produz ou não seus resultados em sala de aula. Procuramos investigar questões do tipo: como e quando os grupos analisados funcionaram? Quais intervenções do professor favoreceram a aprendizagem?

A pesquisa foi desenvolvida numa escola particular no interior de São Paulo, com alunos da $1^{\text {a }}$ série do Ensino Médio cujas aulas de Física foram marcadas pela constância de atividades em grupo em que o professor fazia uma série de intervenções (presencial, institucional e virtual) a fim de tornar o grupo mais operativo. Entre estas, consideramos significativa uma intervenção que consistiu em atribuições de funções (Líder, Anotador e Questionador) para cada um dos membros do grupo e que deveriam ser rotativas a cada atividade. $\mathrm{O}$ nosso trabalho consistiu na descrição dos episódios e na análise dos três grupos que compunham a classe investigada e encontramos resultados bem diferentes para cada um deles que foram caracterizados da seguinte maneira: o grupo 1, da dependência; o grupo 2 da resistência; grupo 3 da mudança.

Utilizamos as concepções de grupos operativos de Pichon-Rivière, que focaliza a tarefa do grupo e o vinculo entre os membros como elementos essenciais do desenvolvimento grupal. Todo o processo tem na comunicação entre os membros do grupo o aspecto principal para atribuição de papéis (porta-voz, líder, bode expiatório e sabotador), os quais vão surgindo ao longo da tarefa e devem ser circular entre os atores. Quando estes estão estereotipados torna-se necessária a intervenção do professor que deve fazê-los circular, proporcionando mudanças que vão caracterizar a aprendizagem. O processo grupal é dividido em três etapas: a pré-tarefa, quando os alunos resistem à mudança; a tarefa, quando, por uma elaboração das ansiedades o grupo resolve atividade; e o projeto, que é o momento da criatividade e de uma projeção das suas atividades para além do "aqui-agora". 


\begin{abstract}
SILVA, Glauco S. F. Teacher's interviews and group's process in the Physics classes: an analysis by operative group theory. 241f. (Master)- Instituto de Física/ Faculdade de Educação, Universidade de São Paulo, São Paulo, 2008.
\end{abstract}

When the teacher invites students to form groups inside the classroom, interpersonal relationship is built among students and teacher which influences the group process. Our work is focused in this process, in how a learning group is able, or not, to achieve good results. Some of our questions were: how and when the analyzed groups worked well? Which of the teacher's interventions were significant to learning?

The research was developed with High School students from a private school in the state of São Paulo. The Physics teacher used to ask them to work in groups and he intervened in order to make the group operative. A significant intervention was the one in which the teacher asked each member of the group to act as an specific role (leader, writer and questioner). For each new activity they should chance roles. In this work, we described the events, analyzed the three groups formed in the chosen classroom and we found out different results for each of them. We could named the groups this way: group 1, of dependency; group 2, of resistance; group 3, of change.

We used some concepts of operative groups from Pichon-Rivière, which focus the task and the bond among the members as essential to the group development. For him, the communication is the main aspect of the process. The roles appear during the development of the task and the members should change them. When they do not change, it is necessary that the teacher intervenes to promote learning. The group process is divided into three stages: the pre-task, when students resist changes; the task, when the group solves their anxieties and develops the activity; the project, which is the moment of creativity. 


\section{SUMÁRIO}

\section{1-INTRODUÇÃ O.....................................................................................................11}

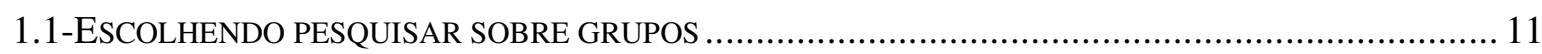

1.2-OUTRAS JUSTIFICATIVAS PARA UMA INVESTIGAÇÃO SOBRE GRUPOS ............................... 13

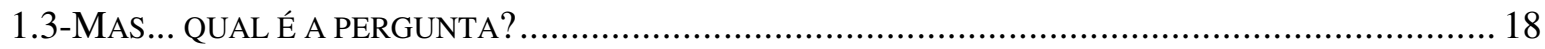

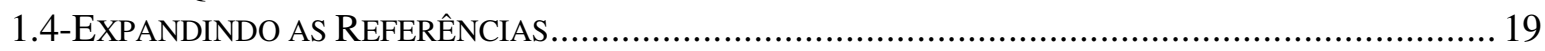

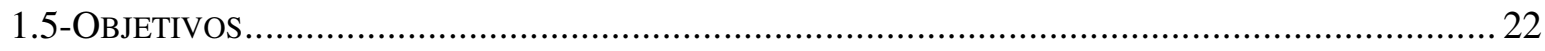

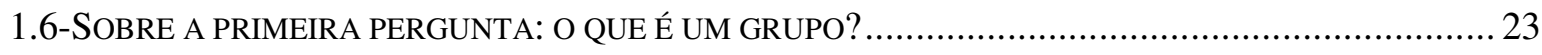

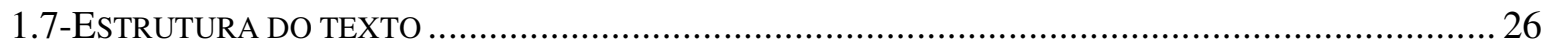

\section{2-A PESQUISA ............................................................................................................29}

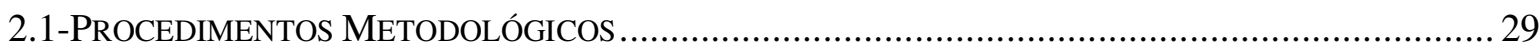

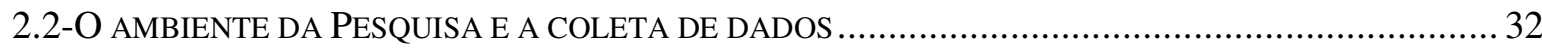

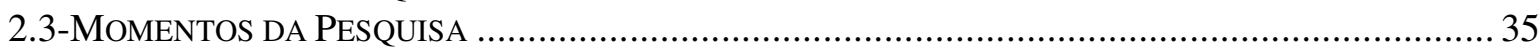

3-REFERENCIAL TEÓRICO ..........................................................................38

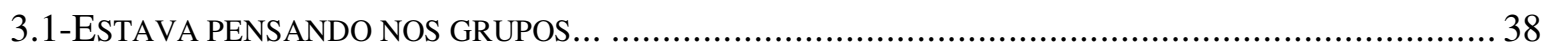

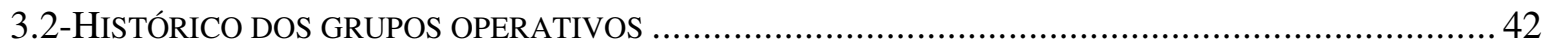

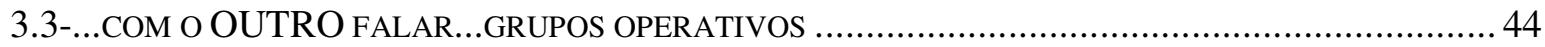

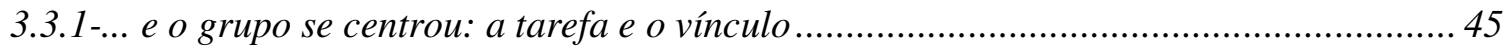

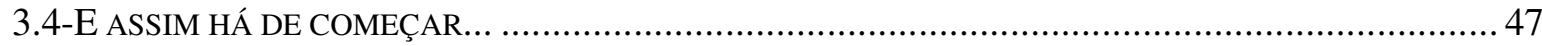

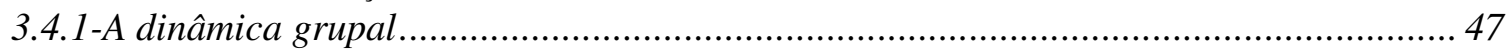

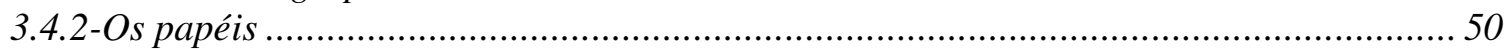

3.4.3-Entre a fusão, com-fusão e situação: as fases do processo grupal ............................... 53

3.4.4-...avaliação, de novo recomeçar: cone e vetores ....................................................... 56

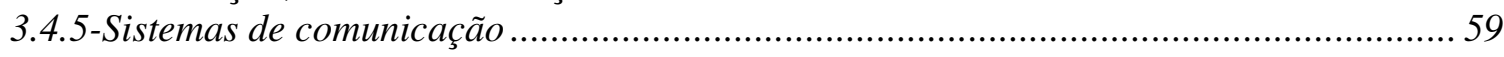

3.5-O COORDENADOR DO GRUPO E AS SUAS INTERVENÇÕES ............................................... 63

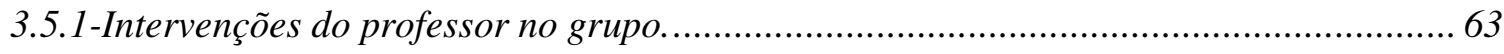

\section{4-ANÁLISE DAS AULAS DOS GRUPOS 3 E 1 .....................................................71}

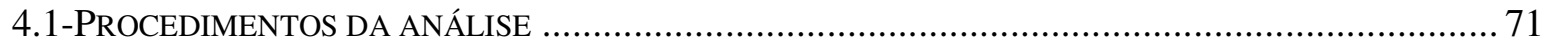

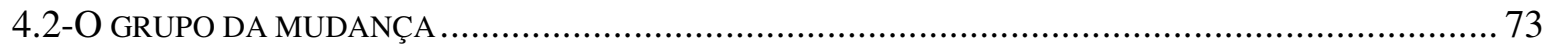

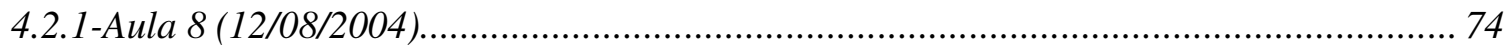

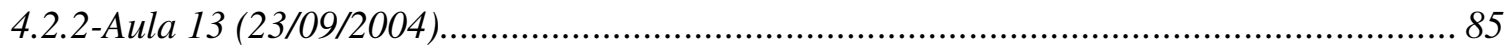

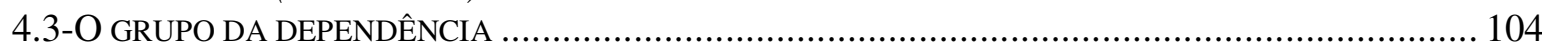

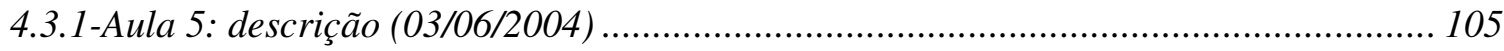

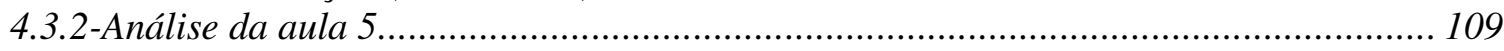

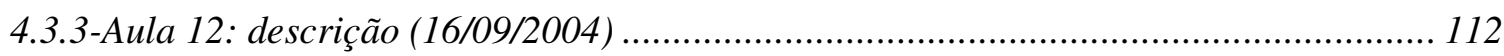

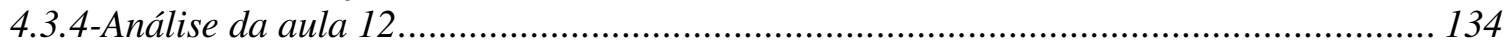


5-ANÁLISE DAS AULAS DO GRUPO 2 ...................................................... 146

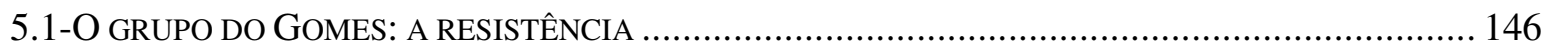

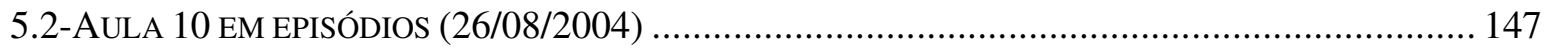

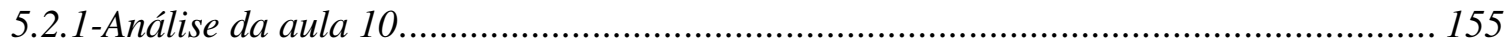

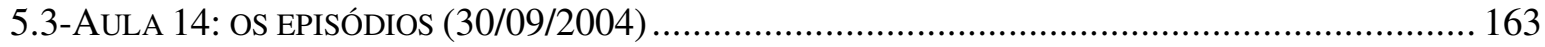

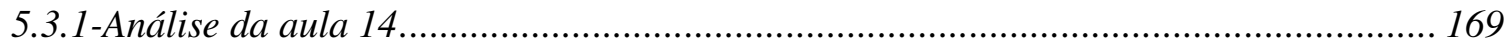

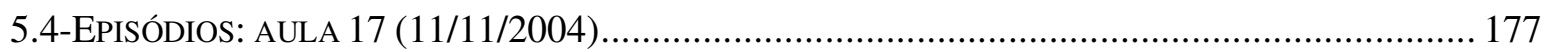

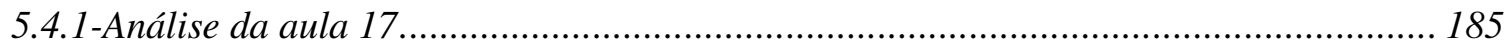

6-CONSIDERAÇÕES FINAIS ........................................................................ 196

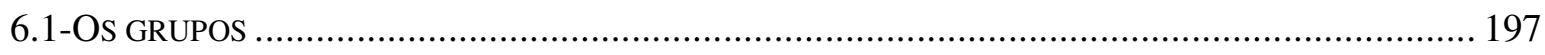

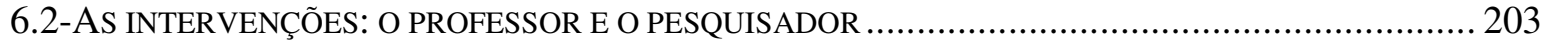

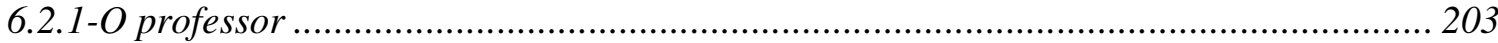

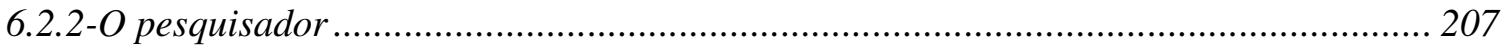

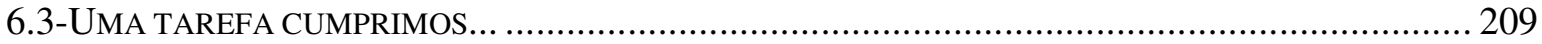

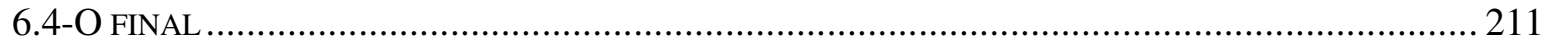

7-REFERENCIAS BIBLIOGRÁFICAS.....................................................216

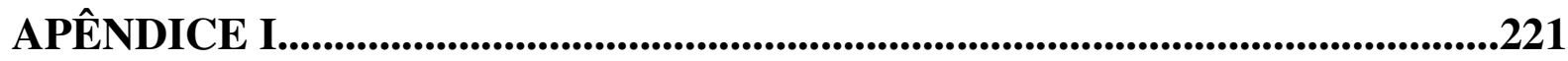

APÊNDICE II.........................................................................................................224

APÊNDICE III..................................................................................................................234 
CAPÍTULO 1 


\section{1-INTRODUÇÃo}

"Não há ensino sem pesquisa e pesquisa sem ensino (...). Enquanto ensino continuando buscando, reprocurando. Ensino porque busco, porque indaguei, porque indago e me indago". "Pesquisar para constatar, constatando, intervenho, intervindo educo e me educo. Pesquiso para conhecer o que ainda não conheço e comunicar ou anunciar a novidade"

(Paulo Freire)

Antes de iniciarmos a explanação trazendo as discussões metodológicas, teóricas e de análise, pedimos licença ao leitor para uma breve introdução às questões pessoais e subjetivas do pesquisador que o conduziram até a presente pesquisa.

\section{1-Escolhendo pesquisar sobre grupos}

Não é fácil pensar com exatidão nos motivos que me impulsionaram a buscar o mestrado em Ensino de Física. Durante a pós-graduação aprendi com a Psicanálise a fazer reconstruções $a$ posteriori de eventos ocorridos em minha vida para tentar justificar uma série de outros que fazem parte do meu momento atual. A seguir, pretendo fazer esse caminho de reconstrução na tentava de situar o leitor, e a mim mesmo, a cerca das minhas opções de pesquisa.

Pretendo não ser muito prolixo. Devo fazer inicialmente um resgate de minha infância, pois aos dez ou onze anos de idade já sonhava com uma profissão: ser professor. Quando me faziam aquela enfadonha pergunta, "o que você vai ser quando crescer?", respondia com toda a certeza de uma criança: “Vou ser professor!”. Não eram raras as vezes que eu trocava o futebol, a bolinha de gude ou a pipa por alguns livros velhos e falava sozinho, simulando uma aula.

O gosto pela ciência me remete à minha quinta e sexta série do Ensino Fundamental em que a minha curiosidade ingênua me levava a perguntar sobre tudo nas aulas, com maior destaque em Ciências. A prática da professora dessa disciplina me chamava a atenção, pois ela entregava a matéria fotocopiada, com muito capricho, e fazia alguns desenhos na lousa, os quais me encantavam pela perfeição. Não havia necessidade de copiar ou escrever o que ela dizia, mas enquanto ela explicava, eu aproveitava para elaborar minhas perguntas, escrevendo-as no meu caderno; mal ela terminava sua explicação e eu já estendia a minha mão e não parava mais de perguntar.

A opção pela Física veio mais tarde, praticamente na época do vestibular, motivado pelo meu professor desta disciplina do terceiro ano do Ensino Médio (que inclusive o reencontrei no $\mathrm{V}$ 
ENPEC $^{1}$ ). Mais uma vez, tive uma influência forte de um professor em cuja admiração estava no jeito como ele conduzia as aulas e a facilidade com que lidava com a Física.

Já na graduação, na Universidade Federal de Juiz de Fora, entrei com a intenção de cursar a licenciatura em Física, mas fui levado pelo fluxo de minha turma e me enveredei para o bacharelado, e fui até final. Porém, em meados do curso vieram algumas decepções que me fizeram refletir e foi quando me dei conta de que não era na carreira de cientista que eu queria me aventurar; iniciei, portanto, a minha jornada para o magistério. Quando optei por outro tipo de pesquisa, comecei a participar de trabalhos em Ensino de Física e veio o primeiro projeto, permanecendo por quase dois anos, no qual está a gênese das questões que me conduziram para o Mestrado.

O projeto de iniciação científica tratava da problemática dos grupos na sala de aula como recurso didático nas aulas de Física I, disciplina introdutória dos conceitos de Mecânica Clássica, ministrada nos primeiros semestres dos cursos de Ciências exatas. Vale salientar que essa disciplina apresentava alto índice de reprovação. O objetivo era avaliar esse mecanismo usado, dado que ele representava uma mudança significativa na forma de abordar essa disciplina e, portanto, era necessário avaliar a sua eficácia. Para isso, aplicamos pré e pós-testes aos alunos e calculamos o ganho normalizado das turmas, verificando que houve um aumento significativo para as turmas que tinham os trabalhos em grupos (BARROS et al, 2004).

Minha participação, além de organizar os dados para se calcular os ganhos dos testes aplicados, consistia em estar presente nas aulas para uma pesquisa do tipo etnográfica que tinha por finalidade tentar descrever aquilo que os números não podiam informar. Foi nesse contexto que, de forma pré-matura, eu comecei a elaborar minhas perguntas para o Mestrado: “como os alunos aprendem quando estão discutindo em grupo? Por que há momentos em que todos se entendem e outros não? Por que alguns grupos conseguem se desenvolver melhor do que outros?" Isso talvez explique a minha opção pelos grupos, ao menos por um lado.

Por outro lado, a minha experiência em grupos é bem marcante, a começar pela minha vivência em família, em grupos de jovens na Igreja, onde até hoje continuo estabelecendo grande parte dos meus laços afetivos, grupos de estudos na graduação e também no Mestrado.

Ao ingressar no Mestrado não me restavam muitas escolhas para o meu projeto a não ser "grupos". A tomada de consciência sobre esse processo, como já disse, foi a posteriori, quando me perguntava como e por que eu cheguei até aqui. Contudo, resta-me uma pergunta: por que escolhi trabalhar com um referencial de grupo de cunho psicanalítico? De início, porque o meu orientador

\footnotetext{
${ }^{1}$ V Encontro de Pesquisa em Educação em Ciências, que é promovido pela ABRAPEC bianualmente e que ocorreu em Bauru-SP, em novembro de 2005.
} 
me apresentou, já que eu tinha um histórico sobre o tema (grupos). Mas depois, fui percebendo como as idéias de Pichon-Rivière acalentavam algumas de minhas inquietações.

Esta dissertação, em sua gênese e essência, constitui uma busca de repostas para algumas das minhas inquietações. Digo algumas, porque outras eu espero respondê-las no Doutorado, e como certamente não conseguirei dar conta de todas elas, terei que passar a vida inteira em busca dessas repostas. Parece-me, então, que é nessa busca que me realizo enquanto pessoa.

\section{2-Outras justificativas para uma investigação sobre grupos}

Os tempos contemporâneos são marcados pelas consequiências da modernidade, que produziram modos de vida que se desvencilharam de todos os tipos tradicionais de ordem social de uma maneira sem precedentes, ditando uma descontinuidade entre o tradicional e o moderno (GIDDENS, 1991). Segundo o autor citado, as mudanças observadas "serviram para estabelecer formas de interconexão social que cobre o globo" (p. 14), marcando assim as descontinuidades caracterizadas pela rapidez e o escopo das transformações e a natureza intrínseca das instituições modernas.

Se por um lado "o desenvolvimento das instituições modernas e suas difusões em escala mundial criaram oportunidade bem maiores dos seres humanos gozarem de uma existência segura e gratificante que qualquer tipo de sistema pré-moderno" (ibid, p 16), por outro, a modernidade promove o fortalecimento do sistema capitalista, que é considerado um sistema de produção de mercadorias baseado na relação entre o dono do capital e o trabalho assalariado cujo eixo principal de funcionamento é o sistema de classes. Como a atividade, o empreendimento capital depende da competitividade entre investidores e produtores gerando uma sociedade de consumo- ou de consumidores (ibid; p 61-69).

As idéias nos parágrafos anteriores nos levam a pensar que as conseqüências da modernidade também atingem a escola. Logo, é razoável imaginar que a lógica capitalista perpassa o campo de educacional no qual a transformação do conhecimento em mercadoria e dos estudantes em concorrentes uns dos outros são marcas deste processo. $\mathrm{O}$ padrão de qualidade passa a ser o índice de produtividade: interessa somente quantos alunos foram aprovados ao fim de cada série, quantos passaram no vestibular, quantos obtiveram bons resultados dos exames de avaliação do governo, etc. Nesse sentido, qual o professor que nunca ouviu seus alunos the perguntando: "se eu fizer a lição de casa, quanto vou ganhar de nota?” Ora, não seria este um pensamento mercadológico: fazer a lição de casa em troca de "capital", a nota? 
Acompanhando as mudanças na ordem social, em especial no último século, as quais ocorreram de forma rápida e profunda, vemos uma série de transformações nas abordagens pedagógicas que agregam em si uma concepção de pessoa e de mundo como reflexo das modificações das relações sociais e culturais ocorridas ao longo dos anos, definindo assim, um modelo de escola, de ensino-aprendizagem (procedimentos didáticos, avaliação, currículo, etc) e de relação professor-aluno. Entre as abordagens, as mais destacadas em geral são: tradicional, comportamentalista, humanista, cognitivista e sócio-cultural. Cada uma delas tem em si aquelas concepções cujo surgimento se deu em momentos históricos diferenciados da sociedade, tanto no âmbito do Brasil quanto mundialmente. (MIZUKAMI, 1986).

Buscava-se assim o enriquecimento do processo de ensino-aprendizagem com as contribuições advindas de algumas Ciências como a biologia, psicologia e a antropologia, quando se transpunha alguns de seus conceitos para o campo educacional. Nessa mesma direção, mais recentemente, novas formas de pensar a educação tem se baseado em outras áreas como a Psicanálise, em que por analogia do processo analítico, utilizam-se alguns de seus conceitos fundantes como instrumento para o manejo do processo de ensino-aprendizagem (LOPES, 1998).

É possível inferir que a busca por essa ciência se deve ao fato de que, como marca da modernidade, a subjetividade, enquanto individualização do sujeito, tem destaque nos discursos da sociedade contemporânea, ou seja, busca-se valorizar o sujeito, as suas ações, pensamentos, ideologias e seus discursos. No campo da educação essa forma de perceber o homem está cada vez mais presente, tanto em algumas de suas produções teóricas como nas práticas pedagógicas (LOPES, 1998; KUPFER, 1989). Então, é nesse sentido que a Psicanálise assume um papel importante, pois como afirma Villani:

“(...) tem-se destacado como um baluarte na defesa das infinitas escolhas possíveis dos homens e na focalização das suas responsabilidades em assumir seus desejos e suas limitações, sem ceder à ilusão de uma vida sem dificuldades, problemas e sofrimentos" $(1999$, p.6).

Trata-se então, de um esforço "em favor da subjetividade das escolhas e contra qualquer processo de massificação" (ibid). Entretanto, entendemos que uma excessiva valorização dessa forma de pensar o sujeito pode nos conduzir a uma perspectiva individualizada do homem, que vai girar em torno de si mesmo. Encontra-se nesse pensamento a nossa primeira justificativa para pesquisar os grupos nos ambientes de ensino-aprendizagem a fim de que possam ser utilizados com mais eficácia numa educação menos individualista.

No que tange o Ensino de Física, a concepção que se faz desta disciplina é que se trata de um conjunto de fórmulas a ser decorado e utilizá-lo em algum tipo de avaliação. Em geral, é tão 
forte essa imagem, que mesmos aqueles estudantes que ainda não tiveram um contato formal com essa disciplina também a concebem assim. Um dos motivos para essa concepção sobre a Física está associado a um ensino que privilegia a resolução de exercícios como uma única forma de se aprender Física, porque, para os que pensam assim, os alunos podem fazer as aplicações das fórmulas que lhes são apresentadas durante as aulas de Física somente resolvendo os exercícios.

Uma das causas para o uso desse modelo nas aulas de Física pode estar vinculada ao fantasma do vestibular, que pressiona as escolas e sistemas educacionais a adotarem como padrão de qualidade os índices de aprovação, em detrimento do processo. Como conseqüência, vemos a adoção em massa dos sistemas apostilados desde as séries fundamentais da Educação Básica, gerando um esvaziamento dos conteúdos curriculares em prol dos exercícios do tipo "decoreba" e promovendo um ensino de Ciências desvencilhado da realidade dos alunos e do professor. Portanto, uma formação que não estimula o senso crítico dos sujeitos envolvidos. A idéia de que Física se aprende resolvendo exercício não está errada, porém o que admitimos é a possibilidade de explorar outras habilidades e competências dos sujeitos durante as aulas dessa disciplina.

Retornando a idéia que lançamos sobre a educação e as influências que lhe atingem devido às transformações sociais, temos de um lado a psicanálise que pode ser explorada no campo educacional visando o sujeito, sua subjetivação e sua autonomia; e do outro temos um movimento crescente de se promover uma educação (científica) para a cidadania, ampliando a sua noção ao se incorporar outros elementos como constituintes deste processo. Esse segundo aspecto foi fortemente impulsionado pela Lei, $n^{\circ}$ 9.394/96, de Diretrizes e Bases (LDB) da educação nacional, em cujos artigos $1^{\circ}$ e $2^{\circ}$, respectivamente citados a seguir, encontramos as premissas da definição de educação:

"A educação abrange os processos formativos que se desenvolvem na vida familiar, na convivência humana, no trabalho, nas instituições de ensino e pesquisa, nos movimentos sociais e nas manifestações culturais."

“A educação (...) será promovida e incentivada com a colaboração da sociedade, visando o pleno desenvolvimento da pessoa, seu preparo para o exercício da cidadania e sua qualificação para o trabalho".

Uma conseqüência dessa Lei foi a elaboração dos Parâmetros Curriculares Nacionais (PCN) que pretendem fazer uma ponte entre a LDB e a prática da sala de aula, trazendo algumas diretrizes e proposições de como promover uma educação com aqueles princípios da Lei em questão. De forma específica na área das Ciências da Natureza e Matemática, os PCN se propõem a um aprofundamento do "sentido do aprendizado na área" apontando de que forma o ensinoaprendizagem de Ciências pode ser complementado e aprofundado no Ensino Médio. Entre os elementos apontados nos PCN para que se atinja tal fim, destacamos dois que nos parecem 
importantes e significativos que justificam, em certo sentido, o desenvolvimento de nosso projeto de pesquisa. No trecho a seguir, menciona-se o que se deve incorporar como organização curricular além dos elementos de conteúdo. Assim, deve haver:

“(...) o reconhecimento e aceitação de que o conhecimento é uma construção coletiva, forjada sócio-interativamente na sala de aula, no trabalho, na família e em todas as demais formas de convivência; reconhecimento de que a aprendizagem mobiliza afetos, emoções e relações com seus pares, além das cognições e habilidades intelectuais" (BRASIL, 2002, p.87, grifo nosso).

Essa orientação nos sugere uma metodologia didático-pedagógica que não seja somente a que temos visto estas últimas décadas, portanto, é importante considerarmos também as situações como discussões, leituras, observações, experimentações e projetos. Afirmamos, então, que é preciso romper com algumas características do campo educacional que sofrem as conseqüencias da modernidade, sobretudo, de uma visão capitalista do mundo, que promove a competitividade e leva o conhecimento ao nível de mercadoria.

Tendo em vista as idéias anteriormente apresentadas - da psicanálise como possível instrumento pedagógico visando o sujeito e de uma educação para a cidadania - concebemos e entendemos que o processo de ensino-aprendizagem é essencialmente coletivo no qual entram em cena elementos da subjetividade de cada um envolvido. O perfil do nosso trabalho vai ao encontro dessa perspectiva, já que a nossa investigação está focada no processo grupal de ensinoaprendizagem.

Os PCN apontam, como rumos e desafios, do Ensino de Ciências dizendo que "se há uma unanimidade, pelo menos no plano dos conceitos entre educadores para a Ciência e a Matemática, é quanto à necessidade de se adotarem métodos de aprendizagem ativo e interativo" (BRASIL, 2002; p 266). Em nossa perspectiva esses métodos podem ser criados através do uso dos grupos como recursos didáticos durante as aulas, pois em um processo fundamentalmente de comunicação, os alunos interagem entre eles e como o professor, de forma ativa, portanto, diferenciada de quando somente o professor tem a palavra, durante as aulas. Em complemento, os PCN ainda afirmam que:

"Os alunos alcançam o aprendizado em um processo complexo, de elaboração pessoal, para o qual o professor e a escola contribuem permitindo ao aluno se comunicar, situar-se em seu grupo, debater sua compreensão, aprender a respeitar e a fazer-se respeitar; dando ao aluno oportunidade de construir modelos explicativos, linhas de argumentação e instrumentos de verificação de contradições; criando situações em que o aluno é instigado ou desafiado a participar e questionar; valorizando as atividades coletivas que propiciem a discussão e a elaboração conjunta de idéias e de práticas; desenvolvendo atividades lúdicas, nas quais o aluno deve se sentir desafiado pelo jogo do conhecimento e não somente pelos outros participantes" (ibid). 
Acreditamos assim que a organização em pequenos grupos nos ambientes de aprendizagem durante as aulas de Física pode favorecer o ensino do conteúdo, a comunicação entre os estudantes e entre estes e o professor, bem como outros aspectos de ordem subjetiva que são necessários para tornar a escola um lugar de formação do cidadão, pois, em geral, esse conjunto de vantagens não é contemplado por inteiro nos currículos de Física.

Além das orientações dos PCN, encontramos na literatura um número expressivo de trabalhos de pesquisadores que apontam algumas características e vantagens de se trabalhar com pequenos grupos na promoção da aprendizagem. Kirschner (1992), por exemplo, acredita que o trabalho em grupo funciona como um instrumento que possibilita o desenvolvimento das capacidades intelectuais dos estudantes e permite que o professor compreenda melhor o processo de interação entre os alunos participantes, auxiliando-o nas suas intervenções. Para Brown et al (1989), o trabalho em grupo se faz mais eficiente que o trabalho individual na medida em que promove a cooperação, oferecendo oportunidades o confronto e debate de idéias e o esclarecimento de dúvidas entre os pares. Coll (2000) diz que interação entre os membros de um grupo contribui para o desenvolvimento de um novo conhecimento, tendo em vista que esse desenvolvimento é social. Além disso, quando se trabalha em cooperação é necessário expressar-se coerentemente ao elaborar um argumento e aprender a ouvir e respeitar outros pontos de vista.

Duschl (1995) acredita que o trabalho em grupo promove uma oportunidade de discussão e argumentação imprescindível no processo de educação científica. Quando argumenta sobre seu ponto de vista o aluno desenvolve mais profundamente a sua compreensão sobre o problema. Heller, $(1992,1999)$ ainda nos diz que quando os alunos trabalham em grupos é possível que estes consigam resolver exercícios mais complexos do que quando tentam sozinhos e que neste processo acabam por utilizar uma linguagem científica da qual se apropriam para fazer seu uso no contexto de ensino-aprendizagem.

Argumentamos acima que organizar a sala de aula em grupos constitui uma contribuição metodológica importante no Ensino de Ciências, da Física em particular, porque esta constituição durante as aulas pode promover uma educação cidadã e ao mesmo tempo levando-se em conta a subjetividade dos atores, rompendo, sob certo sentido, a tendência competitiva e mercadológica que invade, atualmente, os sistemas educacionais.

Diante de tais argumentos, justificamos o nosso tema de pesquisa afirmando que é preciso ter conhecimento teórico sobre os grupos, como que os sujeitos lidam com a situação de coletividade e quais são os aspectos subjetivos emergentes no processo grupal. É importante termos a noção de que todos esses aspectos interferem em sua aprendizagem, pois "através de sua atividade, os seres humanos entram em determinadas relações entre si e com as coisas, além da 
mera vinculação técnica com tarefa", formando assim um "complexo de elementos subjetivos" (BLEGER, 2001, p59-60). Estudar e aprofundar o tema do funcionamento dos grupos torna-se, então, essencial para o sucesso, ainda que unilateralmente, da implementação dos PCN na prática da sala de aula.

\section{3-Mas... qual é a pergunta?}

Ao elegermos como foco de nosso trabalho a compreensão dos processos grupais e sua relação com o Ensino de Física é importante percebermos que quando são investigados os grupos de ensino-aprendizagem, há duas componentes principais de análise, o produto e o processo. A primeira está associada ao o quê o grupo produz, ou seja, a atividade e os resultados encontrados. O outro diz respeito a como o grupo vai produzir, às estratégias que são utilizadas para alcançar o seu objetivo. É nessa segunda dimensão que estamos direcionando este trabalho.

Três questões podem ser consideradas fundamentais em nosso trabalho:

- O que é um grupo?

- Como funciona um grupo?

- Como se conduz um grupo?

Contudo, dentro do que nos estamos nos propondo a fazer, a natureza da nossa pergunta de pesquisa nos gera ainda outras três dimensões possíveis de análise: uma diz respeito aos alunos, como eles atuam nos grupos e que tipo vinculação é gerada; a outra se refere ao professor, ou seja, quais intervenções ele faz e quais os efeitos que estas produzem no processo de ensinoaprendizagem dos estudantes; e a última se refere a tarefa em torno da qual o grupo se organiza. Estas perguntas podem ser reformuladas na seguinte maneira:

- Como ocorrem as interações dentro de um grupo? Quais as dificuldades enfrentadas para alcançar os resultados? Como, quando e por que consegue superá-las? Ou, se for o caso, por que não conseguem superar as dificuldades do processo?

- As intervenções que o professor faz no grupo auxiliam a participação de todos os membros? Como estas auxiliam os alunos? Será que estas ações do professor ajudam o grupo a superar os obstáculos inerentes ao processo? Que o tipo de intervenção é suficiente e necessária para ajudar o grupo a operar melhor?

- Como a tarefa organiza a rede de comunicação entre os atores deste processo? Será possível afirmar que a tarefa promove uma construção de intersubjetividade entre alunos e professor? 


\section{4-Expandindo as referências}

A organização para os trabalhos em grupos para a resolução de problemas em Física de Heller (1999) chamou nossa atenção, porque a autora se utilizou desse recurso para tentar reverter uma situação usual na sala de aula "real": estudantes pouco interessados na disciplina em questão e pouco motivados para estudar de uma maneira geral. Para estimular os alunos durante as suas atividades em grupo, foram introduzidas algumas funções, as quais deveriam ser rotativas a cada aula e a cada atividade, visando uma participação ativa e variada dos alunos na realização da mesma $^{2}$. As funções introduzidas foram: Líder, responsável pela execução da tarefa; Anotador, quem deveria registrar cada etapa das discussões do grupo; e Questionador, responsável por levantar dúvidas no grupo. Os resultados, avaliados através das respostas dos alunos de testes e questionários, apresentaram evidência de melhoria significativa.

Entre os trabalhos de pesquisa que encontramos nos pareceu interessante está o que foi apresentado Hake (1998). Ele fez uma ampla investigação envolvendo mais de seis mil alunos em turmas de Física, tanto do ensino superior quanto do ensino médio. Em seu trabalho, o autor aplicou pré e pós-testes para esses alunos que estavam divididos em turmas que experimentaram o processo de ensino-aprendizagem por meio de uma metodologia que envolvesse grupos (engajamento interativo). O que foi encontrado estava a favor de seu método, pois os resultados obtidos através do ganho normalizado ${ }^{3}$, calculado a partir das médias dos pré e pós-testes, foram superiores para os alunos do engajamento interativo em relação aos que tinham aulas tradicionais com exposição de conteúdo pelo professor.

Também os resultados da pesquisa de Barros et al (2004) nos pareceram animadores. Tratase de uma disciplina de Mecânica Básica ministrada para cursos de graduação da área das Ciências exatas, em que foram organizados em pequenos grupos e estruturados mediante a rotação das funções de Líder, Anotador e Questionador. Os autores se apropriaram do modelo de Heller (1999) e da expressão matemática do ganho normalizado de Hake (1998). Nesse contexto, pré e pós - testes foram aplicados às turmas que experimentaram essa mudança didático-pedagógica tradicionais: os valores dos ganhos normalizados foram significativamente maiores para as turmas experimentais.

Esses resultados ao mesmo tempo em que nos pareceram satisfatórios e interessantes nos deixaram com uma pergunta: por que os alunos nos grupos de aprendizagem apresentaram aqueles resultados? Entendemos que os trabalhos maioria são pesquisas que não focalizam como os alunos

\footnotetext{
${ }^{2}$ Nos capítulos posteriores vamos retornar a este modelo de Heller e seus colaboradores, pois nós utilizamos parte dele em nosso trabalho.

${ }^{3} \mathrm{O}$ ganho normalizado é um calculado pela razão entre a diferença das médias de pós e pré-testes e a diferença de 100 e a média do pré-teste.
} 
em grupo se articulam e vinculam para a realização da tarefa, em torno da qual os alunos se organizam e atuam. Assim sendo, apontamos a seguir alguns resultados de pesquisas envolvendo grupos de alunos nos mais diversos ambientes de ensino-aprendizagem- sala de aula, laboratórios, oficina de Ciências- nos três níveis de ensino, fundamental, médio e universitário. Esses trabalhos possuem certa semelhança com a nossa pesquisa no sentido de que buscam fazer uma aproximação entre os referenciais da psicanálise de grupo e o campo educacional.

Particularmente, encontramos um trabalho muito importante para nossa pesquisa por dois motivos. Em primeiro lugar, trata-se de uma pesquisa realizada no âmbito da educação infantil na qual as crianças participavam de uma oficina de Ciências: as informações sobre os pequenos grupos formados neste ambiente são novas e interessantes . O outro motivo é porque o trabalho tem uma aproximação maior com o nosso, visto que a autora, Rocha (2005), utiliza o mesmo referencial teórico de grupos operativos de Pichon-Rivière, com o foco mais específico nos vínculos formados entre os alunos. Ela descreve a dinâmica de um grupo de alunos entre 9-10 anos de idade, apontando em sua análise os vínculos do grupo com a atividade, com a professora e entre os próprios alunos. Também analisa em seu trabalho o interjogo de papéis que marca a dinâmica desse grupo ao realizar a atividade proposta pela professora. Como conclusão, aponta alguns subsídios para a atuação do professor em ambientes de ensino-aprendizagem de grupos.

Outro trabalho que nos parece importante é o de Sanchez (2002), que também utilizou como referencial os conceitos de grupos operativos. O autor escolheu duas escolas em locais diferentes para servirem como ambientes de pesquisa. Em cada uma delas os alunos, do Ensino Médio, durante as aulas de laboratório de Física foram divididos em grupos. $\mathrm{O}$ estudo foi feito focalizando o processo de mobilização, a criação de vínculos entre os alunos nos grupos e como a aprendizagem ocorria entre eles.

Ainda no ambiente de laboratório de Física, porém no cenário do Ensino Superior, Barolli (1998) investigou grupos de alunos com o objetivo de compreender a sua dinâmica a partir de elementos da cognição e da subjetividade. A autora usou como referencial teórico conceitos psicanalíticos desenvolvidos por W. R. Bion, explorando analogias entre os grupos terapêuticos e de aprendizagem. Nesse trabalho, a autora percebeu o interjogo ocorrido entre o inconsciente, manifestado através de estratégias dos componentes que eram aceitas implicitamente, e o consciente, quando os membros do grupo buscam trabalhar a partir da atividade. Um outro trabalho envolvendo as idéias de Bion é o de Guimarães (2006) em que a pesquisadora investiga um grupo de monitores discentes em algumas reuniões de formação com o professor. $\mathrm{O}$ foco de seu trabalho está na relação que se estabelece entre os alunos, professor e conteúdo de Física envolvido neste processo. 
Barros (2002) em sua pesquisa durante as aulas de Física no Ensino Médio mostra como ocorre a dinâmica grupal apontando para três aspectos: as dificuldades encontradas pelos estudantes na sua estruturação enquanto grupo, a ação efetiva colocada em prática pelo professor e a evolução do grupo durante dois semestres seguidos. $\mathrm{O}$ autor escolheu o referencial de orientação psicanalítica do francês D. Anzieu para a análise dos grupos envolvidos. Valadares \& Villani (2004) trabalham com o referencial da escola francesa da psicanálise de grupos, Renè Käes, analisando um grupo de professores de Ciências que experimentam uma mudança curricular na rede de ensino onde atuavam.

Uma outra referência que se mostrou interessante pela proximidade com os referencias que utilizamos em nosso grupo de pesquisa foi de Pichon-Rivière e Bion. Julio \& Vaz (2005) utilizam estes dois teóricos em uma de sala de aula como instrumento para analisar uma situação de ensinoaprendizagem durante uma atividade guiada pelo professor. Essa atividade era dividida em duas partes: quando os alunos participavam de pequenos grupos e em seguida se reuniam em plenária com toda a classe. Os autores utilizam as idéias de Bion para análise da primeira situação e a noção de grupos operativos para a compreensão do grupo-classe.

No trabalho de Silva (2000), a autora destacou as principais contribuições teóricas da psicanálise de grupo, traçando uma correlação com as situações de sala de aula. O que nos parece mais interessante é um olhar diferenciado que a autora nos oferece de uma sala de aula, enquanto um grupo. Para ela, a questão da indisciplina, por exemplo, pode ser analisada de um ponto de vista da grupalidade, ou seja, aquele aluno que é indisciplinado apresenta um sintoma do grupo em que está inserido. Esse olhar permitirá ao professor outras formas de atuação, que poderão se mostrar eficazes.

Por fim, destacamos três trabalhos que utilizam o referencial de Pichon-Rivière, mas que não estão no âmbito da educação. Fernandes (1989), no campo da Psicologia Social e a Psicanálise, trata de questão do narcisismo e da alteridade na técnica de grupo operativo. Santos (2004) desenvolve o seu trabalho na Psicologia voltado para a sala de aula. Ele estabelece uma relação entre o trabalho grupal na sala de aula e emergência do mundo interno ${ }^{4}$ do sujeito através de relatórios que os estudantes preenchiam como uma das tarefas de uma disciplina no curso de Psicologia. Já Ciampone (1998) desenvolve o seu trabalho no âmbito da Enfermagem e tem o seu interesse em reconhecer e problematizar os aspectos psicossociais e psicodinâmicos relacionados ao

\footnotetext{
${ }^{4} \mathrm{O}$ mundo interno está no quadro conceitual de Pichon; segundo ele é onde são gerados os fantasmas do inconsciente. No processo de comunicação há interferências do mundo interno do sujeito, pois há uma relação com o contexto social dele. Pichon afirma que aqueles fantasmas atuam como um ruído na comunicação e que no processo de vinculação e aprendizagem o mundo interno sofre uma reestruturação. Tais aspectos não fazem parte de nosso objeto de pesquisa. Para uma maior compreensão, vide a referência indicada.
} 
trabalho de enfermagem em instituições de saúde a partir da proposta teórico-técnica dos grupos operativos.

\section{5-Objetivos}

Este trabalho tem como objetivo, principal, pesquisar o processo grupal de alunos nas aulas de Física do Ensino Médio, percebendo a rede de comunicação dos alunos e como as intervenções do professor alteram ou não a dinâmica do grupo. Buscamos explicitar os elementos latentes desse processo dado que essa forma de abordar a sala de aula não é recorrente na literatura.

Constituem-se objetivos específicos:

- Analisar os processos de comunicação verbal que são gerados entre os componentes dos grupos e entre estes e o professor

- Verificar o papel da atividade no processo de organização da matriz vincular dos sujeitos e a sua relação com o conteúdo de Física

- Explicitar os mecanismos dos grupos e como estes podem favorecer (ou não) mudanças no processo grupal

- Verificar como as intervenções (institucional, presencial e virtual) do professor interferem no processo grupal, isto é, como o professor pode auxiliar ou dificultar o processo de aprendizagem

- Analisar qual o efeito produzido com a inserção das funções de Líder, Questionador e Anotador nos grupos (vide capítulo 2).

Para tornar-se um bom cozinheiro é preciso saber manejar bem o fogão, temperar a comida na medida certa, ter noção de quantidades, saber combinar ingredientes e conhecer suas propriedades nutritivas. Da mesma forma, para tornar-se professor de Física, é preciso saber Física, e uma série de outros elementos, como a filosofia e história da ciência, psicologia de educação, elementos da psicanálise, etc. É nesse sentido, de uma formação mais abrangente do docente em Física, que entendemos que o nosso trabalho tem como objetivo secundário fornecer subsídios para o professor de Física, e também de outros campos do saber, para lidar com as situações de coletividade que está sempre presente no processo de ensino-aprendizagem. 


\section{6-Sobre a primeira pergunta: o que é um grupo?}

Quando pensamos em grupos logo imaginamos um conjunto de pessoas que estão reunidas em algum lugar para realizar alguma atividade que lhes seja comum. Essa definição não está errada, porém transmite uma idéia muito vaga dos grupos e de certa forma, podemos dizer que uma configuração assim está mais voltada para um agrupamento de pessoas que pode se transformar em um grupo ou não.

No entanto, esse ponto já nos indica uma problemática, pois para alguns autores aquilo que chamamos de agrupamento já poderia ser configurado como um grupo. É nesse sentido que Bleger (2001) afirma que:

"Em todo grupo, um tipo de relação que é, paradoxalmente, uma não-relação no sentido de uma não individualização que se impõe como matriz ou como estrutura básica de todo grupo e que persiste, de maneira variável, durante toda a sua vida" ( p. 102).

Esse autor amplia a discussão quando indica uma "relação que é, paradoxalmente, uma nãorelação" que já seria para ele um tipo de interação. Como exemplo, o mesmo autor cita o caso em que mãe e filho estão em casa na sala de estar. O filho está desenhando, enquanto a mãe lê. Os dois não estão interagindo, no sentido de que não estão se comunicando verbalmente, mas se a mãe sair da sala, o menino irá interromper a sua atividade para segui-la e estar com ela. Com esse fato podemos compreender que "quando a mãe e seu filho estavam cada um com uma tarefa distinta, sem se falar (...) sem dúvida havia entre eles uma ligação profunda, pré-verbal, que nem sequer necessita das palavras" (ibid, p. 107).

A esse tipo de relação "não-relação" Bleger chama de "sociabilidade sincrética" 5 . Seguindo essa perspectiva, uma fila de ônibus ou de supermercado teria características de grupo, visto que "podemos participar como indivíduos em interação na medida em que participamos de uma convenção de modelos e normas que são mudas, mas que estão presentes” (ibid, p. 109). Porém, não pretendemos avançar nessas questões em nosso trabalho, queremos apenar chamar a atenção para o fato de que ao se tratar de grupos estamos em um campo de problemáticas em que há várias possibilidades de abordagem do tema (FERNANDES, 1989).

A visão de grupos que adotamos diz respeito a uma concepção interacionista em que se enquadra o modelo de grupos operativos. Em linhas gerais, isso significa que para haver um grupo é necessário que os sujeitos interajam, gestual ou verbalmente, gerando um tipo de rede de

\footnotetext{
5 Para maiores detalhes vide a referencia: BLEGER, J, O grupo como instituição e o grupo nas instituições. In:___ Temas de Psicologia: Entrevista e Grupos, 2a ed, São Paulo: Martins Fontes, 2001
} 
comunicação (vincular) entre eles. Dessa forma, as perguntas a seguir são relevantes: Quando um agrupamento de pessoas passa a se configurar como um grupo? Com quantas pessoas se define um grupo? Esse número precisa ser restrito? Uma multidão poderia se configurar como um grupo? O que seria um grupo afinal?

A noção de grupo tal como a concebemos atualmente- que de acordo com o Dicionário eletrônico Houaiss ${ }^{6}$ apresenta as seguintes acepções: "conjunto de pessoas ou coisas dispostas proximamente e formando um todo; reunião de várias pessoas; conjunto de pessoas ou coisas que têm características, traços, objetivos, interesses comuns; conjunto de seres ou coisas cujas características comuns são utilizadas para sua classificação"- nem sempre foi assim, como nos mostram os trabalhos de Fernández (2006), Souto et al (1999) e Anzieu \& Martin (1971) que buscam o sentido da palavra "grupo" a partir de uma reflexão sobre a etimologia deste vocábulo.

Fernández (2006) se justifica dizendo que "para além da relevância histórica que essa tarefa possa ter, interessa pensar dentro do próprio campo semântico. Espera-se que as linhas de significação trazidas à luz tornem possíveis certas visibilidades com relação às diversas produções de sentido que a palavra 'grupo' disparou historicamente" (p17). Na mesma direção Souto et al (1999) dizem que essa busca etimológica se faz importante para perceber os sentidos que a palavra "grupo" tem e como ocorrem as modificações ao ser inserida no campo teórico.

O primeiro fato que nos chama a atenção nas pesquisas de Anzieu \& Martin (1971) e de Fernández (2006) é a constatação de que o vocábulo "grupo" não existia entre as línguas ocidentais mais antigas, ou seja, não havia nenhum termo para designar um conjunto de pessoas que compartilham algum objetivo em comum. Segundo Fernández (2006), "grupo" enquanto um termo para significar algo passou a ser usado na modernidade, sobretudo na época do Renascimento.

Etimologicamente, vemos que a palavra "grupo" em português, mas também em francês, "groupe" e ainda em espanhol "grupo", tem sua origem em comum do termo italiano "groppo" ou “gruppo”. De acordo com Fernández (2006):

"Groppo aludia a um conjunto de pessoas esculpidas ou pintadas, passando por volta do século XVIII a significar uma reunião de pessoas, e rapidamente seu uso coloquial se espalhou. Groppo scultorico é uma forma artística própria do Renascimento, através da qual as esculturas que em tempos medievais estavam sempre integradas ao edifício passam a ser expressões artísticas em volume, separadas dos prédios, ao redor das quais é possível caminhar para apreciá-las, ou seja, é possível rodeá-las; (...) ao mesmo tempo outra das características do groppo scultorico é que as sua figuras ganham mais sentido quando observadas como conjunto do que isoladamente" (p 1718)

\footnotetext{
${ }^{6}$ Consultado em 15 de fevereiro de 2008.
} 
O termo groppo, antes de significar reunião de pessoas, era “nó”. O vocábulo em questão teria derivado do antigo provençal ${ }^{7}$, grop, que significava nó. O termo teria ainda outra origem do germano Kruppa, que era massa arredondada, fazendo menção a uma forma circular (ibid).

A palavra "grupo" então comporta esses dois significados, nó e círculo. Isso significa que de um lado temos a idéia de nó, no sentido de uma coesão necessária entre os membros do grupo (vínculo). E do outro, a noção de círculo, no sentido de uma reunião de pessoas, trazendo a idéia de eqüidistância da borda deste círculo até o centro. Uma imagem que pode nos ajudar são os Cavaleiros da Távola Redonda e ainda a "ordem religiosa dos Templários, cujo altar circular permitia que todos estivessem, na missa, numa mesma distância de Deus" (FERNÁNDEZ, 2006, p. 20).

É possível pensar em um grupo com os sentidos de nó e círculo quase de maneira intuitiva, porque nas diversas situações em que são formados opta-se por dispor os sujeitos em um formato circular, pois facilita o intercâmbio entre eles, de maneira especial por meio do olhar. Uma outra conotação sugerida no formato circular é que dispostos desta forma, os integrantes teriam uma igualdade hierárquica, ou seja, seria o mesmo que dizer que ao sentar-se em círculo a relação entre os sujeitos estaria democratizada. Isso pode ser mais uma vez exemplificado pelos Cavaleiros da Távola Redonda com a idéia da eqüidistância de qualquer lugar da borda do círculo até o centro. Contudo, vale lembrar que "o mero sentar-se em círculo não determina igualdades hierárquicas nem atenua os jogos de poder" (FERNANDEZ, 2006, p.21).

A introdução de um novo termo, grupo, indica uma representação simbólica de um novo "objeto" que até certo momento da história não tinha sido pensado nem nomeado:

“(...) Surge em um momento histórico que torna 'necessária' tal palavra para a produção de representações do mundo social. Sua nomeação torna visível uma forma de sociabilidade - os pequenos grupos humanos - que com a modernidade adquire relevância nas práticas sociais para gerar uma palavra específica. $\mathrm{O}$ surgimento desse vocábulo inscreve-se no complexo processo de transformações tanto das formas de sociabilidade, das práticas sociais e das subjetividades, como de novas figuras que os atores sociais darão às 'representações' que constroem o mundo em que vivem” (ibid, p24-25, grifo nosso).

A gênese do vocábulo grupo ainda estaria ligada a uma mudança social que ocorrera no período do Renascimento quando a homem passa a ser o centro das atenções. Ocorre nessa época uma mudança das servidões a Deus para uma autonomia do homem, que imagina ser capaz de se realizar longe da figura divina. Essa guinada na forma de pensar diz respeito ao processo de constituição da subjetividade do ser humano que é quando as ciências humanas começam a surgir

\footnotetext{
${ }^{7}$ O Provençal era uma língua falada por habitantes na região da França e Itália, por volta do século IX.
} 
trazendo questões do tipo: “O que é o Homem?". É o período em que o comércio começa a se expandir com o advento das navegações tendo como consequiência um maior intercâmbio cultural entre alguns povos. No campo da arte, o groppo passa a não mais estar agregado às grandes construções, mas encontra-se nas praças junto das pessoas. Observa-se ainda o que poderíamos chamar de nucleação da família, que "inicia um processo de transformações, reduzindo-se de suas extensas redes de sociabilidade feudal até conformar a família nuclear moderna" (ibid, p.22).

Souto et al (1999) dizem que é possível levantar hipóteses sobre as resistências sóciohistóricas que operaram para aparecimento tardio da noção de grupo ocorresse. Porém, o que vai lhe despertar maior interesse é um fenômeno semelhante ao da história no campo pedagógico, pois o mesmo obstáculo de alguma forma se apresenta por meio de concepções fortemente individualistas que ainda são utilizadas. Em outras palavras, não se trata somente de usar ou não grupos nos ambientes de ensino-aprendizagem, mas sim da apropriação do conceito de grupo e da consciência do que fazemos quando instituímos grupos (vinculados a algumas correntes teóricas) por parte dos docentes e formadores. Por fim, os autores em questão levantam a seguinte questão: "qual é aceitação real (...) do grupo como um objeto a ser pensado e com o qual operar?" (p. 36, tradução nossa).

\section{7-Estrutura do texto}

Inicialmente, buscamos apresentar as nossas justificativas para a pesquisa sobre a temática dos grupos, bem como iluminar etimologicamente a palavra-chave de nossa pesquisa: grupo. Para uma discussão mais completa, apresentamos no apêndice II uma perspectiva epistemológica sobre o grupo, ou seja, como o concebem no campo teórico. Nessa mesma parte da dissertação apresentamos o que chamamos de "ajustes terminológicos sobre a grupalidade".

No próximo capítulo descrevemos com detalhes a metodologia que usamos para a pesquisa e bem como a metodologia de análise, que assume um caráter peculiar entre os trabalhos de nosso grupo de pesquisa. Acrescentamos também nesse capítulo uma descrição do ambiente de pesquisa e dos grupos investigados.

A segunda questão a que nos colocamos- como funciona um grupo?- será abordada no capítulo terceiro a partir do referencial teórico de Grupos Operativos. Esse capítulo está composto de forma tal que apresentaremos uma noção geral sobre o grupo numa concepção interacionista, o histórico sobre a técnica operativa e os principais conceitos de sua teoria. As intervenções do professor nos grupos ganharão um destaque especial por se tratar de um aspecto importante do seu

funcionamento. É a partir daí que se inicia a discussão de como podemos usar os grupos como recurso didático nas aulas de Física. 
A análise foi divida em duas partes nos capítulos quatro e quinto. Naquele apresentaremos a descrição e interpretação das aulas de dois dos grupos (3 e 1) pesquisados e no outro do ultimo grupo (2). A separação foi feita para colocar em destaque esse ultimo grupo, por se tratar de um caso especial e nos surpreender com a sua dinâmica.

No epílogo resgatamos a análise dos grupos a fim de possibilitar uma visão geral e perceber os movimentos comuns dos três grupos (a questão da liderança, a presença do novo e os atravessamentos institucionais). Em seguida, discutimos o lugar do professor no processo grupal e como o pesquisador foi percebido por cada grupo e, ao abordarmos essas questões, tocamos na questão da intervenção do professor e do pesquisador juntos aos alunos nos grupo. Por fim, discutimos as potencialidades e limitações do trabalho, apontamos ainda algumas perspectivas futuras para o mesmo. 
CAPÍTULO 2 


\section{2-A Pesquisa}

\section{1-Procedimentos Metodológicos}

A base de nossos procedimentos metodológicos advém da pesquisa qualitativa, pois estamos interessados no processo dos grupos de alunos que estamos analisando e os aspectos subjetivos das relações que se estabelecem entres sujeitos da pesquisa, bem como nas intervenções do professor. Portanto, os procedimentos de pesquisa que escolhemos nos permitem controlar algumas variáveis que estão presentes em nosso trabalho com maior eficácia do que numa pesquisa quantitativa. $\mathrm{O}$ modelo da pesquisa quialitativa tem orientado as investigações na área de Ensino de Ciências, desde a década de 1980, as quais têm importantes contribuições capazes de dar significado a diversas situações de ensino-aprendizagem que procuram investigar (BAROLLI et al, 2007).

Iniciamos por definir a pesquisa qualitativa:

“(...) é o termo que vem sendo usado alternativamente para designar várias abordagens à pesquisa em ensino, tais como pesquisa etnográfica, participativa observacional, estudo de caso (...). Cada uma delas forma um todo coerente englobando suposições internamente consistentes sobre natureza humana, sociedade, objeto de estudo e metodologia (...)". (MOREIRA, 1990, p.32).

Esse modelo de pesquisa está embasado na idéia de que a realidade a ser investigada é socialmente construída e a partir disto busca-se entender e compreender o fenômeno social, que pode ser no campo da Educação ou na própria Sociologia. O pesquisador se encontra totalmente imerso no seu campo de pesquisa e esta imersão é necessária para a compreensão do fenômeno que se está pesquisando. Os resultados a serem encontrados estão totalmente vinculados com o pesquisador, que em muitos casos se torna a principal fonte dos dados (LÜDKE \& ANDRÉ, 1986; FILHO \& GAMBOA, 1997).

É comum atribuir à pesquisa qualitativa o título de interpretativa, visto que segundo Moreira (1990), o interesse central da investigação está "na questão dos significados que as pessoas atribuem a eventos e objetos, em suas ações e interações dentro de um contexto social, e na elucidação e exposição desses significados pelo pesquisador" (p.32).

Tal como na pesquisa quantitativa, o pesquisador qualitativo (ou interpretativo), registra eventos, toma dados, controla variáveis e o que os diferencia é a forma como cada um vai realizar as etapas da pesquisa: o pesquisador qualitativo faz observações participantes no próprio ambiente de pesquisa; anota com cuidado os acontecimentos ocorridos neste ambiente; faz registros através de vídeo e/ou áudio e pode ainda recolher documentos, tais como escritos de alunos e professores, 
materiais entregues aos alunos ou aos professores, para o caso da pesquisa em ensino. Ele sempre busca em uma situação específica de sua pesquisa: descobrir o que há nela de único e o que permite fazer generalizações (MOREIRA, 1990).

As idéias de Lüdke \& André (1986) sintetizam a pesquisa qualitativa: (i) o ambiente natural torna-se fonte direta dos dados e o pesquisador o instrumento principal; (ii) os dados têm uma característica descritiva; (iii) preocupa-se mais com o processo do que com o produto; (iv) a interpretação do pesquisador dos significados que as pessoas dão às coisas e a sua vida; (v) a análise tem uma tendência a seguir um processo indutivo. Contudo, recentemente, há vários outros caminhos que vem sendo tentados com a finalidade de aprimorar a qualidade e relevância dos resultados (BAROLLI, et al, 2007). Em uma publicação importante de Santos \& Greca (2006), encontramos um compêndio de algumas metodologias utilizadas para a pesquisa em Ensino de Ciências: subsídios para a pesquisa entre educação científica e cultura; aprimoramento de captação e armazenamento digitais, sofisticação em entrevistas e análise de discurso.

Acrescenta-se aos nossos procedimentos metodológicos o fato de este trabalho estar vinculado a um grupo de pesquisadores que pretende explorar as contribuições da Psicanálise para a pesquisa em Educação em Ciências, contidas naquele compêndio mencionado anteriormente. O grupo é orientado por uma metodologia de pesquisa específica, cuja base não se desvincula da pesquisa qualitativa. Buscam-se, inicialmente, situações que podem ser interpretadas de maneira satisfatória pelo referencial da psicanálise individual ou grupal, focalizando "as diferentes relações que os sujeitos adotam ante o conhecimento e os condicionantes subjetivos fazem com que tais relações se estabeleçam daquela forma" (VILLANI et al, 2006, p.325). Ao optar por essa forma de conduzir as pesquisas e a análise, acreditamos que é uma maneira promissora, já que consideramos elementos da subjetividade tanto dos sujeitos da pesquisa (professor e alunos em nosso caso) e do pesquisador, os quais são poucos explorados nas pesquisas em Ensino de Física.

O desenvolvimento das pesquisas é marcado por duas etapas fundamentais que são a escolha de um referencial teórico para análise e a busca de situações que possam ser interpretadas de maneira satisfatória por meio do referencial, mas não necessariamente nesta ordem (VILLANI et al, 2006; BAROLLI et al, 2007). Assim, a situação a ser estudada deverá aproximar-se de uma experiência educacional capaz de trazer um conhecimento novo e que venha a ser em um primeiro momento uma: 
“(...) novidade objetiva constituída, por exemplo, pelos fatos decorrentes da implementação de uma metodologia de ensino potencialmente promissora, de um currículo ou de um conteúdo inovadores, pela presença de novas relações entre alunos e professores, pela proposta de um trajeto institucional diferenciado ou mesmo por uma rotina de sala de aula que não consegue ser modificada" (VILLANI et al, 2006, p.329, grifo nosso).

Dessa forma, com o referencial escolhido, o nosso grupo de pesquisadores busca compreender as "novidades objetivas", tomando como base a subjetividade envolvida no evento em análise:

"Com base na reconstrução feita pelo pesquisador, os outros membros [pesquisadores] se dispõem a levantar questões e sugerir hipóteses sobre a dinâmica dos eventos relatados, pois, (...) os estados subjetivos que marcam o pesquisador durante a vivência e registros dos dados são elementos relevantes na elaboração da análise" (BAROLLI, et al, 2007, p. 255)

Caracteriza-se assim em nossa metodologia de pesquisa a perspectiva de que o inconsciente permeia as relações de ensino-aprendizagem e tornando-se, por esta razão, a possibilidade de uma analogia com a psicanálise individual ou a de grupo (VILLANI, 1999). Nessa perspectiva, explorase a analogia entre a Psicanálise e Educação em Ciências, cujo referencial teórico permite deslocar os tipos de problemas que são atacados tradicionalmente, ou seja:

“(...) o centro das atenções deixou de ser a dificuldade do aprendiz em entender os vários conceitos científicos (...) e passou para a tentativa de compreender sua resistência em iniciar uma busca do conhecimento e sua fragilidade em sustentar o esforço necessário numa procura ou, ao contrário, seu investimento na aprendizagem" (VILLANI et al, 2006, p.326).

Podemos sintetizar todo esse processo em algumas etapas fundamentais, tomando-se como base a perspectiva psicanalítica nos processos educativos. Fazemos uma recuperação a posteriori dos dados, por meio do questionamento dos pares ao pesquisador, construindo uma história marcada por fases que são determinadas por momentos de dificuldades, de impasses ou de sucessos que os sujeitos experimentam: "a função é permitir que elementos de natureza inconsciente, ou ao menos não explicitamente conscientes, na ocasião dos eventos, possam ser recuperados" (BAROLLI, et al, 2007, p. 255). Logo, a análise é conduzida de forma que o grupo de pesquisadores esteja numa posição de "atenção flutuante", para que no processo de "livre associação" permita-se a emergência de novos elementos da pesquisa relatada (ibid). 
Acrescentamos ainda que:

"Um outro aspecto importante na escolha dos casos estudados pelo grupo [de pesquisadores] está na possibilidade de sua descrição por meio de uma narrativa individual ou memória sócio-histórica (...). As escolhas realizadas até o momento presente têm privilegiado dois tipos fundamentais: a reconstrução, mediante entrevistas e análise documental de eventos passados, particularmente significativos para a educação, e o acompanhamento on line da realização de novas experiências"(ibid, p.331; grifo nosso).

Constituem-se como etapas principais:

- A escolha do caso que deverá se apresentar como uma novidade objetiva, que pode ser alguma experiência educacional que possa ser analisada, como o caso de nosso trabalho, ao estudarmos a inserção de grupos de aprendizagem nas aulas de Física. Esse processo envolve a escolha de um referencial teórico que incorpore os elementos da subjetividade.

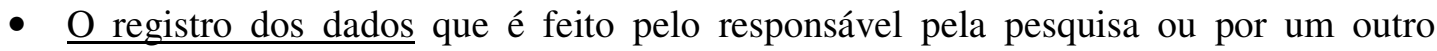
pesquisador que acompanha as intervenções de campo do primeiro através de notas ou por meio eletrônico. A entrada desses elementos- o pesquisador e, possivelmente, um outro que lhe acompanha para o registro escrito e eletrônico- geram um espectro maior de informações sobre o caso estudado, possibilitando a reconstrução dos eventos com maior fidedignidade.

- $\quad$ Análise dos dados, que tem um enfoque qualitativo, acontece essencialmente quando é feita uma reconstrução do evento. É nessa etapa que o grupo de pesquisadores que atua como uma segunda testemunha no auxílio do pesquisador responsável para a reconstrução dos eventos.

Encontramos um número razoável de trabalhos acadêmicos (teses e dissertações) que foram concluídos por membros desse grupo de pesquisadores, a saber: Ferreira (1997), Cabral (1998), Barolli (1998), Freitas (1998), Arruda (2001), Ferreira (2001), Barros (2002), Sanchez (2002), Valadares (2002), Franzoni (2004), Fernandes (2007).

\section{2-O ambiente da Pesquisa e a coleta de dados}

Os dados foram coletados em uma escola particular localizada em Jundiaí-SP, em uma turma da primeira série do Ensino Médio. A escolha da classe analisada foi devida às facilidades advindas pelo fato do professor responsável também estar vinculado ao nosso grupo de pesquisa. É importante salientar que o pesquisador não era o professor da turma investigada, tendo feito apenas algumas intervenções nos grupos em algumas aulas. 
$\mathrm{Na}$ tabela abaixo mostramos como a turma era composta nos dois semestres do ano letivo de 2004, quando ocorreu a pesquisa, com destaque para uma pequena mudança na classe devido à entrada e saída de alunos. A ordem dos grupos é a mesma apresentada na análise.

\begin{tabular}{|c|c|c|c|}
\hline & NOMES & FAIXA ETÁRIA & CARACTERÍSTICAS \\
\hline \multirow{2}{*}{$\begin{array}{l}\text { GRUPO } 3 \\
\text { (G 3) }\end{array}$} & $\begin{array}{l}\text { 1sem: Tito, Valentim, } \\
\text { Ricardo, Kevin }\end{array}$ & \multirow{2}{*}{$14-15$} & \multirow{2}{*}{$\begin{array}{l}\text { Saída de Kevin no fim } \\
\text { do primeiro semestre a } \\
\text { entrada de Hernam. }\end{array}$} \\
\hline & $\begin{array}{l}\text { 2sem: Tito, Valentim, } \\
\text { Ricardo, Hernam }\end{array}$ & & \\
\hline \multirow{2}{*}{$\begin{array}{l}\text { GRUPO } 1 \\
\text { (G 1) }\end{array}$} & $\begin{array}{l}\text { 1sem: Janaína, } \\
\text { Camila, Rebeca, } \\
\text { Carmem }\end{array}$ & \multirow{2}{*}{$14-15$} & \multirow{2}{*}{$\begin{array}{l}\text { Duas modificações ao } \\
\text { longo do ano: saída de } \\
\text { Janaína na virada de } \\
\text { semestre e a entrada de } \\
\text { Eugênia no último } \\
\text { bimestre. }\end{array}$} \\
\hline & $\begin{array}{l}\text { 2sem: Rebeca, } \\
\text { Camila, Carmem, } \\
\text { (Eugênia) }\end{array}$ & & \\
\hline $\begin{array}{l}\text { GRUPO } 2 \\
\quad(\text { G 2) }\end{array}$ & $\begin{array}{l}\text { Leandro, Gomes, } \\
\text { Alan, Tim }\end{array}$ & $15-16$ & $\begin{array}{l}\text { Manteve-se com os } \\
\text { mesmos alunos. } \\
\text { Encontra-se aqui o } \\
\text { único aluno repetente } \\
\text { da turma. }\end{array}$ \\
\hline
\end{tabular}

Quadro-1-Panorama geral da turma investigada com a indicação de saídas e entradas dos alunos.

Utilizamos a técnica da observação participante para a coleta dos dados, em que o pesquisador permaneceu no ambiente de pesquisa durante os eventos, colaborando com o docente em alguns momentos e elaborando notas de campo, as quais the permitiram reconstruir os eventos mais significativos ocorridos durante o trabalho dos grupos, seguindo aquela heurística descrita na seção anterior.

O recurso da gravação em vídeo também foi utilizado, porque a filmagem dos alunos contribuiu para fornecer informações mais detalhados da dinâmica grupal. Trata-se, portanto, de uma técnica bastante útil e importante para a análise mais pormenorizada dos eventos- falas dos atores, impasses e problemas durante a resolução da atividade, momentos de silêncio- que ocorrem durante os trabalhos em grupo (LABURÚ et al, 2000, CARVALHO, 2006). O uso da vídeogravação é uma prática muito comum entre as pesquisas em Ensino de Ciências, pois, argumentam os que a utilizam, que filmagem representa um instrumento fidedigno de investigação cuja observação se torna controlada e sistematizada (LÜDKE \& ANDRÉ, 1986). 
Segundo Giordan (2006),

"a pesquisa em situações de ensino da sala de aula tem sido influenciada, entre outros fatores, pelos meios de registro disponíveis para observar alunos e professores. A popularização dos meios magnéticos de registros de áudio [e vídeo] influenciou pesquisas sobre a dinâmica discursiva que se iniciaram na década de 70 (...). Revisões sobre pesquisa nessa área (...) indicam que a apropriação de registro de áudio e vídeo pelos pesquisadores alterou a forma como se realiza pesquisa em sala de aula" (p.214).

Com o uso desse recurso nas pesquisas em sala de aula, torna-se necessário os cuidados com as questões éticas agregadas à prática da filmagem. Ressaltamos, então, que antes de introduzirmos o aparelho na sala de aula foi solicitado à escola a autorização, bem como para os pais dos alunos envolvidos na pesquisa. Foi esclarecido que a imagem dos estudantes seria utilizada somente para fins acadêmicos, cuja divulgação da mesma estaria disponível somente para o grupo de pesquisadores, quando eventualmente fosse necessário o seu uso para a análise, sem sua divulgação em nenhum meio de comunicação.

A filmadora foi colocada na sala de aula posicionada sempre perto de um dos grupos a fim de que se registrassem as falas e os gestos dos alunos e professor, com alguma ênfase para as intervenções do professor nos grupos. A partir do referencial adotado, esses registros serão utilizados para reconstruir as histórias de cada grupo procurando identificar eventos significativos nas etapas do processo grupal.

Nessa escola o currículo previa um encontro por semana com o professor de Física; na ocasião os alunos participavam de três aulas consecutivas (de 50 minutos). Em cada encontro semanal (que doravante vamos nomeá-lo por aula) os alunos participavam das aulas em plenária ${ }^{8}$ e desenvolviam atividades em grupos, as quais oscilavam entre exercícios do livro texto adotado, exercícios que o professor elaborava ou questões relacionadas com a aula expositiva, mas sempre em consonância com o programa curricular da escola. Tais atividades não aconteciam em uma seqüência prefixada ou em um momento específico da aula, pois dependiam sempre da dinâmica do professor e do conteúdo em questão, diferente do trabalho de Barros et al (2004) em que as atividade em grupo eram sempre após a aula expositiva.

\footnotetext{
${ }^{8}$ Estas aulas em plenárias são as aulas expositivas do professor que podiam ocorrer tanto antes quanto depois das atividades em grupos. Há ocasiões inclusive, que só acontecem as aulas expositivas. Então, não usamos o termo plenária tal como em Julio \& Vaz (2005), pois neste caso tratava-se de uma das etapas das atividades guiadas pelo professor e que também foi objeto de análise dos pesquisadores citados.
} 


\section{3-Momentos da Pesquisa}

A pesquisa de campo foi dividida em dois momentos: a primeira, que se desenvolveu no primeiro semestre, foi um processo de adaptação dos alunos com a presença do pesquisador e viceversa. Nesse momento, não tínhamos ainda um microfone para ser colocado junto ao grupo e a filmadora não ficava bem posicionada por falta de um tripé. O momento seguinte foi caracterizado por uma duração maior, desde agosto a dezembro de 2004 e os problemas apontados anteriormente já haviam sido solucionados. O número total de aulas filmadas, com as respectivas notas de campo, foi de 20: as sete primeiras compõem o primeiro momento e as demais ocorridas durante o segundo semestre serão usadas para a análise em maior quantidade. Optamos por dividir nesses momentos a pesquisa, porque facilita a análise das aulas e porque ocorreram modificações na estruturas dos grupos (vide quadro 1).

O segundo momento foi marcado por uma intervenção do professor nos grupos que poderíamos qualificar como "institucional" 9 . Após observar as gravações das aulas das primeiras aulas e com base em trabalhos já realizados (HELLER, 1999, BARROS et al, 2004) o professor instituiu funções nos grupos, as quais deveriam ser rotativas entre os alunos a cada atividade. Chamamos a atenção para o fato de que escreveremos as funções sempre com letras maiúsculas para diferenciá-las de outros termos semelhantes advindos do referencial teórico. Elas são baseadas no trabalho de Heller (1999) e descritas a seguir:

- Líder - responsável pela execução das atividades. Ele deve direcionar a seqüência da resolução para que o grupo não perca o objetivo da discussão. Ele também deve certificar-se do envolvimento de todos os membros do grupo nas atividades, sendo responsável também por controlar o tempo.

- Anotador - responsável por registrar cada etapa das discussões do grupo. Cabe-lhe, entre outras coisas, a função de registrar o pensamento do grupo no papel e confirmar se todos estão entendendo o que é escrito.

- Questionador - responsável por levantar dúvidas. Ele deve questionar cada detalhe das soluções propostas e permitir que só se passe para outra etapa quando tudo estivesse esclarecido.

Os quadros abaixo mostram como foi a distribuição dos grupos filmados ao longo do ano de 2004 Estão indicados a numeração das aulas com suas respectivas datas. As marcações dizem qual foi o grupo filmado, e quando não houver nada indicado significa que não houve trabalho em grupo

\footnotetext{
${ }^{9}$ Veremos com mais detalhes esta intervenção institucional no próximo capítulo quando abordaremos o referencial teórico.
} 
naquela aula. No quadro $2 \mathrm{~b}$, nas últimas duas aulas foram feitas as entrevistas em grupo (25/11) e individual (02/12).

\begin{tabular}{|c|c|c|c|c|c|c|c|}
\hline & 1 & 2 & 3 & 4 & 5 & 6 & 7 \\
\hline $1^{\text {o }}$ semestre & $06 / 05$ & $13 / 05$ & $20 / 05$ & $27 / 05$ & $03 / 06$ & $17 / 06$ & $23 / 06$ \\
\hline Grupo 1 & & & $\mathrm{X}$ & & & & \\
\hline Grupo 2 & & $\mathrm{X}$ & & & $\mathrm{X}$ & & \\
\hline Grupo 3 & $\mathrm{X}$ & & & $\mathrm{X}$ & & & \\
\hline
\end{tabular}

Quadro- 2a-Distribuição dos grupos filmados no primeiro semestre. A numeração na linha em destaque corresponde ao número da aula com sua respectiva data. As colunas sem a marcação indicam que não houve atividade de grupo naquela aula.

\begin{tabular}{|c|c|c|c|c|c|c|c|c|c|c|c|}
\hline & 8 & 9 & 10 & 11 & 12 & 13 & 14 & 15 & 18 & 19 & 20 \\
\hline $\begin{array}{c}2^{\circ} \\
\text { semestre }\end{array}$ & $12 / 08$ & $19 / 08$ & $26 / 08$ & $02 / 09$ & $16 / 09$ & $23 / 09$ & $30 / 09$ & $07 / 10$ & $21 / 10$ & $11 / 11$ & $18 / 11$ \\
\hline Grupo 1 & & & & & $X$ & & & & $X$ & & \\
\hline Grupo 2 & & $\mathrm{X}$ & & & & $\mathrm{X}$ & & & $\mathrm{X}$ & \\
\hline Grupo 3 & $\mathrm{X}$ & & & & & $\mathrm{X}$ & & $\mathrm{X}$ & & & $\mathrm{X}$ \\
\hline
\end{tabular}

Quadro- 2b- Distribuição dos grupos filmados no segundo semestre. A numeração na linha em destaque corresponde ao número da aula com sua respectiva data. As colunas sem a marcação indicam que não houve atividade de grupo naquela aula. 
CAPÍTULO 3 


\title{
3-REFERENCIAL TEÓRICO
}

Dada uma visão geral sobre o tema do grupo, vamos abordar, neste capítulo, o modelo de grupo operativo, referencial teórico que adotamos para análise dos nossos dados. Proposto por Enrique Pichon-Rivière, o modelo em questão diz respeito essencialmente a uma técnica de intervenção terapêutica fortemente marcada por uma concepção de sujeito. De acordo com o autor em questão, "o sujeito não é só um sujeito relacionado, é um sujeito produzido numa práxis" (PICHON-RIVIÈRE, 2005 p.238). A sua concepção o levará a afirmar que o grupo constitui um campo operacional privilegiado, pois a análise das interações permite que se estabeleçam hipóteses sobre os processos dos sujeitos aí envolvidos.

\section{1-Estava pensando nos grupos...}

\author{
Estava pensando nos grupos \\ e de repente me dei conta: \\ como é dificil manter-se em situação. \\ Muitos querem tirar-nos dela. \\ São aqueles que se mantém em confusão. \\ Porque seguro estou ... \\ de por ela termos de passar (a confusão) \\ porque é o primeiro momento \\ que todo grupo atravessa \\ a caminho de sua organização.
}

As estrofes são de um poema do professor Guerín (vide apêndice 1) cujo tema se refere aos grupos. No trecho aqui apresentado - ao longo do texto serão citados outros trechos da poesia do mesmo autor-, ele está se referindo aos momentos iniciais da formação de um grupo quando os sujeitos estão em processo de afiliação, se conhecendo e se organizando. Trataremos a seguir desse mesmo tema, evidenciando algumas características principais a fim de servir de base para o referencial adotado.

Aqueles versos indicam como um grupo inicia seu processo de configuração, a partir da percepção que cada membro tem do outro e de si. Esse momento inicial de confusão diz respeito às primeiras projeções e transferências que ocorrem entre os sujeitos e se referem às primeiras formas de vinculação, que podemos remetê-las àquela idéia de nó contida na acepção da palavra "grupo". Entendemos por projeção, no sentido propriamente psicanalítico, "a operação pela qual o indivíduo expulsa de si e localiza no outro, pessoa ou coisa, qualidades, sentimentos, desejos e mesmo 'objetos' que ele desdenha ou recusa em si” (LAPLANCHE \& PONTALIS, 1988, p. 478). 
E por transferência "o processo pelo qual os desejos inconscientes se atualizam sobre determinados objetos no quadro de um certo tipo de relação estabelecido com eles" (ibid, p. 668).

O caminho da organização do grupo se dá a partir da instituição de um enquadre ou de um setting que vai funcionar como um cenário para os sujeitos atuarem. $\mathrm{O}$ enquadre é uma espécie de contrato que é firmado entre o fundador do grupo e seus membros, que diz respeito: à tarefa comum dos sujeitos, ao objetivo e finalidades; ao número de pessoas envolvidas; à quantidade de encontros e o tempo de duração de cada um deles. Em outras palavras:

"No início de um grupo, deve haver a instituição de um enquadre e o cumprimento das combinações nele feitas, isto é, (...) estabelecer os parâmetros a serem adotados nos encontros, como elementos fixos a serem mantidos durante o contrato estabelecido com grupo que deve manter o seu consentimento e acordo para que o trabalho seja iniciado. Cabe então definir local (...), regras de participação como número de faltas, compromisso com a comunicação de ausências (...) e outras variáveis ou regras básicas que possam normatizar as atividades grupais propostas”. (CIAMPONE, 1998, p. 120).

Em certo sentido, o enquadramento dá conta de uma primeira organização, sendo necessária sua manutenção por parte da equipe de coordenação ${ }^{10}$. Ademais, aqueles processos de projeção, transferências múltiplas (geração de vínculos) e a comunicação entre os seus membros, conferem ao grupo um aspecto psíquico e social (SOUTO, 1993; MARTINS, 2002). A combinação desses fatores pode nos levar a pensar que, uma vez juntos, os membros de um grupo vão compor um todo que passa a ser um somatório de pessoas. Contra essa idéia, Souto (1993) vai se manifestar dizendo que se trata de um sistema complexo, composto por uma diversidade interna. Um grupo, afirma ela:

"É constituído por relações partes- todo nas quais o todo tem características de conjunto que lhe dêem certa identidade, e (...) as partes conservam certos traços e características próprias. O todo não será uma unificação de partes, senão unidade de interações, de relações recíprocas, de encontros que dão uma organização peculiar e possibilidades de auto-organização em função das relações internas e externas com o entorno social mais amplo" (p. 30, tradução nossa).

Essa citação nos propõe uma relação entre o "entorno social mais amplo" e a configuração que o grupo experimenta, corroborando com a idéia explicitada acima. Os eventos que ocorrem no grupo, como vai superar ou não a fase da confusão, sofrem influências não somente dos aspectos psíquicos e do enquadre normativo, mas também dos aspectos sociais de onde se reúne.

Então, é possível pensar o grupo sob dois pontos de vista: macro, em que se torna possível perceber que os seus mecanismos, tais como, seus sistemas de regras; e micro, em que se

\footnotetext{
${ }^{10}$ A idéia de um enquadre e a sua manutenção por parte da equipe de coordenação é o que vai sustentar a nossa hipótese sobre as intervenções do professor no grupo, que podem assumir um caráter institucional e presencial.
} 
identificam os papéis e lugares que os sujeitos ocupam no grupo, como resultado das múltiplas transferências, projeções, processos de comunicação, etc. Isso implica em dizer que o grupo está posto como um tipo de mediação entre o individual e o coletivo, entre sujeito e sociedade. Dentro dessa perspectiva, podemos fazer a seguinte ilustração:

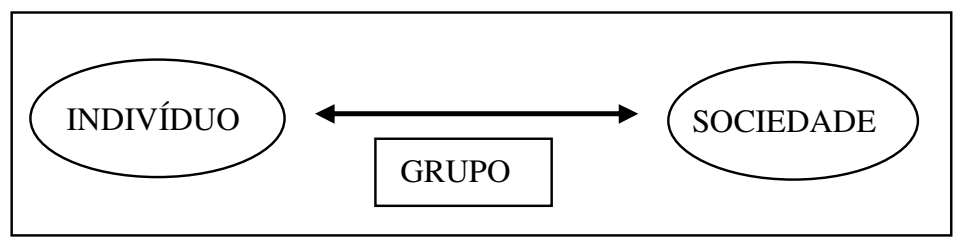

Fig. 1- O grupo primário visto como mediador das relações entre o indivíduo e a sociedade

Segundo Fernandez (2006), essa forma de pensar o grupo, como mediador da dicotomia indivíduo-sociedade, é fruto de um pensamento ocidental que costuma articular como "lógicas binárias hierarquizantes antinomias tais como: material-ideal, alma-corpo, ser-ter, objetivosubjetivo, público-privado, as quais são abarcadas desde o ponto de vista da filosofia, da política e da ciência" (p.49). Ela defende que seja necessário repensar aquela noção segundo a qual os grupos constituem um campo de mediações entre indivíduos e sociedade em cuja argumentação ela diz:

“As operações que as diversas disciplinas humanísticas parecem ter realizado em seus momentos iniciais consistiu em dividir ilusoriamente o campo de indagações em dois objetos de estudo 'bem' diferenciados: indivíduos e sociedades, organizando diferentes áreas e práticas disciplinares para em seguida buscar as formas nas quais fosse possível pôr em jogo suas relações. Isso tornou necessário demarcar os campos de saberes e suas práticas mediadoras" (p.49).

Pichon-Rivière (1994) assinala que existem três desses níveis, para a promoção da investigação: do indivíduo, a do grupo e da instituição ou sociedade. A partir disso pode-se fazer três tipos de análise: a psicossocial (que parte do indivíduo que se expressa para fora, que se dirige para os diferentes objetos que o rodeiam); a sociodinâmica (que analisa o grupo como estrutura, considerando as diferentes tensões entre todos os objetos que configuram a sua estrutura); e a institucional (que assume o grupo como objeto de pesquisa total, sua estrutura, origem, história, etc, e que situa o sujeito como componente de uma instituição). A partir desses elementos é perfeitamente possível estudar com operacionalidade científica as relações interpessoais que se estabelecem no grupo. Podemos esquematizá-los, na figura abaixo, indicando que é impossível uma separação clara entre esses campos de investigação, já que eles vão se integrando sucessivamente. 


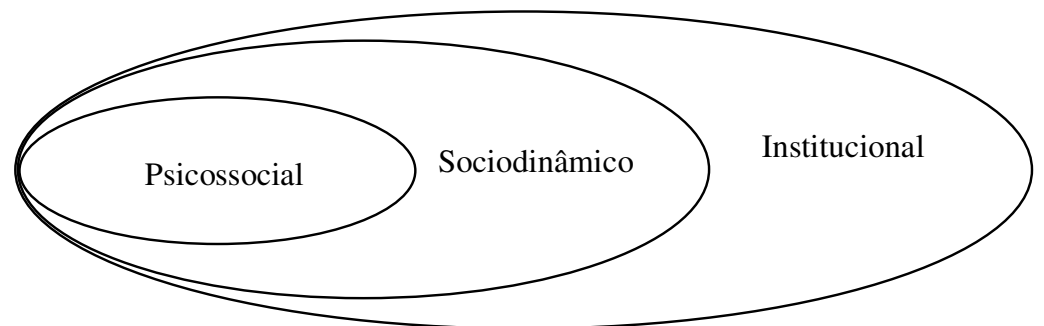

Fig. 2- Os níveis de investigação que aponta Pichon-Rivière. O grupo operativo está no sociodinâmico.

Sobre o psicossocial, dizemos que analisa a "parte do sujeito que se expressa para fora, que se dirige aos diferentes membros que o rodeiam enquanto que o sociodinâmico analisa as diversas tensões existentes (...) que configuram a estrutura de um grupo" (ibid, p 27). Então, um grupo, cuja técnica de intervenção está centrada na tarefa, portanto operativo, se localiza no campo sócio dinâmico de investigação, por se tratar de um dispositivo privilegiado para o grupo "manter-se em situação", saindo da confusão para uma configuração, por assim dizer, mais evoluída:

E assim há de começar ...

uma, duas e mais reuniões também.

$\hat{E}$ um momento de FUSÃO.

O denominador é a CON-FUSÃO.

Mas, seguramente ...

deste momento há que sair,

porque o homem em SITUAÇÃO

não pode permanecer na confusão,

embora, por ela, sempre tenha que passar:

esse é o caminho do viver.

Não vem quem não passa pela confusão.

Não vem quem fica na confusão.

Podemos então resumir a nossa visão do que seja um grupo a partir de Zimermam (1993):

- Um grupo não é um mero somatório de indivíduos, ele se constitui como uma nova entidade, com leis e mecanismos próprios e específicos. Podemos dizer que assim como todo indivíduo se comporta como se fosse um grupo (de personagens internos), da mesma forma todo grupo se comporta como se fosse uma individualidade

- Todos os integrantes de um grupo estão reunidos em torno de uma tarefa ou objetivos comuns

- O tamanho do grupo não pode exceder o limite que ponha em risco a sua comunicação, tanto visual como a auditiva e a verbal

- Deve-se haver a instituição de um enquadre (setting) e o cumprimento das combinações nelas feitas

- Um grupo se processa em dois planos: um da intencionalidade consciente, manifesta, e outro movido por fatores inconscientes, implícitos ou latentes (processos 
identificatórios; transferências e contratransferências; ressonâncias; continências; fantasias; ansiedades; medos; papéis, etc.)

- É inerente a todo grupo o surgimento de interações afetivas, de natureza múltipla e variada

- O grupo, com finalidade operativa ou terapêutica, necessita de um coordenador para que sua integração seja mantida

- Em um grupo encontro entre a verticalidade, aquilo que o sujeito traz consigo; e a horizontalidade, o que é construído em conjunto.

\author{
Porque é um momento do todo \\ em sua totalidade... \\ Mas não há de ser \\ a totalidade do todo.
}

Passemos agora para uma explanação mais detalhada sobre o referencial teórico que estamos utilizando em nossa pesquisa.

\title{
3.2-Histórico dos grupos operativos
}

Para a nossa pesquisa estamos usando o referencial teórico de Enrique Pichon-Rivière, de orientação psicanalítica, em que nos apropriamos dos conceitos por ele desenvolvidos sobre grupos operativos. Pichon-Rivière nasceu na Suíça em 1907, tendo se mudado com seus pais para Argentina aos quatro anos de idade, onde produziu a sua obra, que foi fruto de sua vivência em dois modelos culturais bem distintos entre si, como afirma próprio autor:

"Eu poderia dizer que minha vocação pelas Ciências do Homem surge na tentativa de resolver a obscuridade do conflito entre duas culturas. Em virtude da emigração de meus pais de Genebra para Chaco, fui, desde os quatro anos, testemunha e protagonista da inserção de um grupo minoritário europeu num estilo de vida primitivo. Assim, ocorreu a incorporação, certamente não inteiramente discriminada, de dois modelos culturais quase opostos. Meu interesse pela observação da realidade teve, inicialmente, características pré-científicas, e mais exatamente, místicas e mágicas, adquirindo uma metodologia científica através da tarefa psiquiátrica" (PICHON-RIVIÈRE, 2005, p.1-2).

A citação acima se encontra no prólogo do livro O Processo Grupal em que ele narra as suas premissas de como foi construindo as suas idéias sobre a psicanálise e a psicologia social. Pichon também relata que a cultura guarani, na qual ficou imerso até os seus dezoito anos, era composta por mitos que conduziam este povo a uma concepção de mundo "de caráter mágico e regido pela culpa cujas noções de morte, luto e loucura formavam o contexto geral da mitologia guarani" (ibid, 
p.2). O contato com essa cultura e a internalização dessas estruturas teria dirigido o seu interesse para o "desvelamento do implícito", cuja vocação analítica está associada a sua vivencia:

“(...) minha vocação analítica surge como necessidade de esclarecimento dos mistérios familiares e de questionamento dos motivos que dirigiam o comportamento imediato e mediato dos grupos. Os mistérios não esclarecidos no plano do imediato (...) e a explicação mágica das relações entre o homem e a natureza determinaram em mim a curiosidade, ponto de partida de minha vocação para as Ciências do Homem” (ibid, p.3-4).

Imerso nesse contexto de mitos, aos poucos foi surgindo um interesse pela observação dos "personagens protótipos" que assumem um significado especial nas pequenas populações. O seu interesse estaria orientado de forma inconsciente para a descoberta dos modelos simbólicos que são explicitados no inter-jogo de papéis que configura a vida de um grupo social. Então ele passa a explorar "a inter-relação dialética entre o homem e seu meio" (ibid, p3).

A teoria e técnica de grupos operativos tiveram sua gênese na Experiência de Rosário, como nos mostra Abduch (2004):

“(...) o fenômeno disparador da técnica de grupos operativos foi um incidente vivido no hospital psiquiátrico De Las Mercês, em Rosário, onde desempenhava atividades clínicas e docentes. Este incidente foi a greve do pessoal da enfermagem desse hospital. Para superar aquela situação crítica, Pichon-Rivière colocou os pacientes menos comprometidos para assistir aos mais comprometidos. Observou que ambos subgrupos apresentaram melhoras de seus quadros clínicos".

Como afirma o próprio Pichon, sua cientificidade se dá na sua tarefa psiquiátrica, disparada por tal evento, com o qual inicia um processo de elaboração do seu esquema referencial de grupos operativos. Ele o desenvolveu a partir da psicanálise Kleiniana e Freudiana, da teria de campo de Kurt Lewin e da teoria de Comunicação e Interação. É válido ressaltar que para Psicologia Social, área em que Pichon se propôs atuar, o maior valor de seu trabalho foi ter desenvolvido uma ciência para ser praticada, visando a transformação da realidade (FERNANDES, 2003). 


\title{
3.3-...com o OUTRO falar...grupos operativos
}

\author{
...os grupos primeiro se formam \\ do coletivo (série) tentando sair. \\ Reúnem-se aqueles que conseguiram \\ com o OUTRO falar ... \\ $e$, nesse momento, não mais \\ eu, com você, quero falar! \\ Falando já estamos, companheiro, \\ mas falta algo mais ... \\ Com quem você veio? \\ Com um amigo, e talvez mais! ... \\ Eu também tenho um, e outros mais. \\ Pois adiante, quando nos reunimos?
}

Um grupo operativo pode ser descrito segundo sua técnica da seguinte forma:

"A técnica desses grupos está centrada na tarefa, na qual teoria e prática se resolvem numa práxis permanente e concreta no 'aqui e agora' de cada campo assinalado. As finalidades e propósitos dos grupos operativos podem ser resumidos dizendo-se que sua atividade está centrada na mobilização de estruturas estereotipadas por causa do montante de ansiedade despertada por toda mudança (...). No grupo operativo, o esclarecimento, a comunicação, a aprendizagem e a resolução de tarefas coincidem com a cura, criando-se um novo esquema referencial" (PICHON-RIVIÈRE, 2005, p.137-138).

Ao afirmar que sua técnica está centrada na tarefa, Pichon a compara com outras duas modalidades de dispositivos grupais: grupos centrados no indivíduo, e grupos centrados no grupo. A primeira implica em grupos psicanalíticos ou de terapia, nos quais a tarefa do terapeuta se focaliza naquele que sempre anuncia algo, que para Pichon é o porta-voz (isso será explicado mais abaixo). Sua crítica consiste em perceber que nesses casos não está incluída a problemática do grupo. Na outra técnica cuja análise se concentra na própria dinâmica do grupo, não se considera a relação sujeito-grupo, que para Pichon é fundamental (ibid, p. 271-272).

A operatividade está, então, no fato de que se trata de um grupo centrado na tarefa, o que significa centrar-se "nos problemas da tarefa, da aprendizagem, e problemas pessoais relacionados com a tarefa, com a aprendizagem" (ibid, p.272). E como veremos, a concepção pichoneana de aprendizagem consiste na mudança que o sujeito em ação ou sujeito operativo experimenta, a partir da superação do montante de ansiedade que é despertado diante do novo.

Os temas principais sobre os grupos operativos, que serão abordados neste capítulo, são: a noção de tarefa (atividade centrada na tarefa); vínculo; mobilização de estruturas internas; comunicação e aprendizagem; e os papéis no momento das interações. Estes conceitos dizem respeito ao processo do grupo, ou seja, ao processo do sujeito que é produzido no grupo. 


\title{
3.3.1-... e o grupo se centrou: a tarefa e o vínculo
}

\author{
Na primeira reunião, \\ Já se falou de TAREFA. \\ Só se a anunciou ... \\ mas o grupo se centrou. \\ Porque não há grupo sem tarefa. \\ Essa é uma realidade: \\ explícita ou latente, \\ sempre ela existe.
}

O grupo operativo pode ser definido como um conjunto de pessoas que tem um objetivo em comum e que procuram abordá-lo trabalhando em equipe à medida que operam (BLEGER, 2001). O fator principal de se considerar que há um objetivo comum para o grupo é perceber que há uma tarefa comum. Assim, "a tarefa é um organizador dos processos de pensamento, de comunicação e de ação que ocorrem na situação de grupo" (FERNANDES, 2003, p. 197). Nas palavras de Pichon-Rivière (2005):

“(...) um conjunto de pessoas reunidas por constantes de tempo e espaço, articuladas por sua mútua representação interna, que se propõe implícita e explicitamente a uma tarefa que constitui sua finalidade" (p.216)

A tarefa que "consiste na abordagem do objeto" (ibid, p.273) possui duas dimensões: uma explícita e uma implícita. A primeira diz respeito ao objetivo direto do grupo, ou seja, o trabalho a ser produzido- um exercício ou a realização de uma experiência de Física- que constitui a razão de ser do grupo. Já a tarefa implícita se caracteriza na manutenção da coesão do grupo durante a realização da tarefa explícita. Para tanto, o grupo deve superar os obstáculos surgidos, como a formação de subgrupos dispersivos e manter a esperança de que a meta poderá ser atingida pelo grupo.

Durante o processo de abordagem do objeto, aquilo que está explícito, na realização da tarefa, seja na fala ou nos gestos, pode significar a ocorrência de tipos de dificuldades que aparecem como sinais, emergentes, do obstáculo epistemológico que está relacionado com a resistência à mudança:

“(...) o obstáculo epistemológico centra as resistências à mudança e nossa tarefa é justamente promover uma mudança (num sentido grupal) operativa (mudança de uma situação para outra), em que o explícito que tomamos como manifesto é interpretado até que apareça algo novo, uma descoberta" (ibid., p. 274).

As finalidades da técnica de um grupo operativo consistem, então, na mobilização do mundo interno do sujeito, as suas estruturas internas, o qual é construído por um processo 
progressivo de internalizarão de objetos e relações (PICHON-RIVIÈRE, 2005, SANTOS, 2004, CIAMPONE, 1998).

Passamos agora para uma explicação mais detalhada. $\mathrm{O}$ aspecto principal de um grupo operativo de aprendizagem diz respeito à sua capacidade de mobilizar as estruturas internas dos participantes fazendo com que eles superem suas dificuldades de aprendizagem e comunicação. No mundo interno, o sujeito tenta reconstruir a realidade exterior, mas na passagem do fora para o dentro o cenário exterior sofre certas modificações. Isso nos leva a pensar que, se o consideramos como constituinte do sujeito, aceitamos então que o mundo interno é acessado no processo grupal (e também nas relações sociais em geral), no processo de relação de objeto (SANTOS, 2004). O que se observa é um aspecto dinâmico de intersubjetividades dos mundos interno e externo.

A indagação analítica sobre o mundo interno que Pichon faz,amplia a noção de relação de objeto- a considera como relação intersubjetiva entre os mundos internos e externos- formulando assim, o seu conceito de vínculo, o qual é definido "como uma estrutura complexa que inclui um sujeito, um objeto e sua mútua inter-relação com processos de comunicação e aprendizagem" (PICHON-RIVIÈRE, 2005, p.5). Nesse sentido, os vínculos que os sujeitos criam nas suas relações (com outros sujeitos ou objetos) são considerados como diferentes modalidades da passagem (fantasiada) do fora para o âmbito intra-subjetivo, o dentro. Sobre a noção de vínculo, Pichon ainda afirma que:

"Essas relações intersubjetivas são dirigidas e estabelecem-se com base em necessidades, fundamento motivacional do vínculo. Tais necessidades têm um matiz e intensidades particulares, nos quais já intervém a fantasia do inconsciente. Todo vínculo, assim entendido, implica na existência de um emissor, um receptor, uma codificação e decodificação da mensagem. Através deste processo comunicacional, torna-se manifesto o sentido da inclusão do objeto no vínculo (...). Por isso insistimos que em toda estrutura vincular (...) o sujeito e o objeto interagem realimentando-se mutuamente" (ibid, p.5).

Cria-se então uma nova antinomia, mundo interno-mundo externo, que vai ser resolvida de forma dialética, não linear e como conseqüência disso a formação da estrutura vincular ocorre em um processo de internalização, logo essa estrutura passa a ter uma dimensão intra-subjetiva. O processo pode ser tal que apareça a configuração de um vínculo bom ou um vínculo mau, um vínculo normal ou patológico relacionado com um sentimento de gratificação ou de frustração, respectivamente. Como exemplo de algumas dessas situações temos:

"O vínculo paranóico caracteriza-se pela desconfiança, pela exigência que o sujeito experimenta em relação aos outros. O vínculo depressivo caracterizase por estar permanentemente carregado de culpa e expiação, enquanto que o vínculo obsessivo se relaciona com o controle e com a ordem. O vínculo 
hipocondríaco é aquele que o indivíduo estabelece com os outros através do seu corpo, da saúde e da queixa (...)” (PICHON-RIVIÈRE, 1994, p 24).

Nesse sentido, as múltiplas transferências, as projeções e identificações são determinantes na construção da rede vincular de um grupo, bem como na construção de intersubjetividades entre os sujeitos e objetos envolvido no processo grupal. E por fim, vale ressaltar que ninguém apresenta um único tipo de vínculo, pois "todas as relações de objeto e todas as relações estabelecida com o mundo são mistas" (ibid, p.26).

O que caracteriza um grupo operativo essencialmente é então, ser centrado na tarefa e ter na sua base a construção de vínculos, que se dá, sobretudo, na realização da tarefa implícita, enquanto o grupo luta contra os obstáculos que podem desintegrá-lo. No que diz respeito à tarefa, há uma complementaridade entre suas dimensões: somente a realização da tarefa explícita levaria o grupo a uma completa desordem, o que poderia desintegrá-lo e por outro lado, somente a realização da tarefa implícita não teria sentido e se configuraria em um simples encontro de pessoas, pois é a primeira que funda o grupo.

\title{
3.4-E assim há de começar...
}

\author{
E assim há de começar... \\ uma, duas e mais reuniões também. \\ É um momento de FUSÃO. \\ $O$ denominador é a CON-FUSÃO.
}

\subsection{1-A dinâmica grupal}

"A árvore da montanha olê ia ô! A árvore da montanha olê ia ô!"

Um grupo de pessoas recebeu uma tarefa que lhes parecia um tanto desafiadora ${ }^{11}$. Eles tinham de cortar uma árvore e construir uma canoa. Ao receberem a notícia foram então procurar uma árvore para cumprirem com o seu objetivo e ao encontrá-la logo imaginaram estratégias de como cortá-la e como iam fazer a canoa. Até que ela ficasse pronta, eram necessárias várias etapas sucessivas que o grupo deveria seguir, mas a primeira e talvez mais importante, era cortar a árvore. Porém, havia uma resistência em efetuar o corte, pois alguns alegavam que estariam desmatando a floresta e que em tempos de discussão com o aquecimento global não seria muito prudente e que o melhor a ser feito era voltar, alegar isso a quem lhes dera a tarefa e propor outra forma mais ecológica de construir a tal canoa. Alguns concordam e outros não, e depois de um tempo resolveram cortá-la. Neste momento, o grupo enfrentou um novo momento de crise, pois não havia

\footnotetext{
${ }^{11}$ Essa analogia foi usada pela Prof. Maria Inês A. Fernandes durante a disciplina Processos Grupais, por ela ministrada no Instituto de Psicologia da Universidade de São Paulo.
} 
árvore e tão pouco a canoa. Essa etapa foi caracterizada por um apego a árvore que não existia mais e a desesperança de também não haver a canoa.

O instrutor que lhes dera a tarefa foi até o local onde o grupo estava reunido para a construção da canoa e percebeu que eles estavam perdidos e que dificilmente conseguiriam sair daquela situação. Então ele os ajudou os ajudou dando-lhes algumas dicas de o que e como poderiam fazer e, além disso, alimentou a esperança a cerca cumprimento da tarefa. A partir daí, os componentes do grupo elaboraram estratégias para as etapas sucessivas e as idéias foram surgindo de um e de outro. E assim, foram aprendendo a superar as dificuldades, e para resumir a história, conseguiram então construir a canoa. A etapa seguinte era colocá-la no rio e esperar que ela não afundasse!

A fim de explicarmos melhor o funcionamento de um grupo, segundo as idéias de PichonRivière, utilizamos uma pequena história como uma analogia do processo grupal. Assim, o grupo é fundado com a tarefa que lhe foi dada: cortar uma árvore e construir uma canoa. Para nós, aquele instrutor será o professor que distribui as atividades para os grupos de aluno na sala de aula.

Toda situação de novidade causa no sujeito uma ansiedade, pois não se sabe o que virá a partir daí. Quando surge a iniciativa de não cortar árvore em prol de uma consciência ecológica, queremos mostrar justamente essa ansiedade diante do novo, e o mesmo ocorre quando já não tinham mais a árvore. Nessas etapas, o grupo entra na posição esquizoparanóide, ou seja, momento em que os sujeitos nos grupos vivenciam uma cisão, uma ruptura e precisam estar apegado a algo que já conhecem e que sabem controlar; como conseqüência eles simulam a realização da tarefa e atuam como se a estivesse cumprindo.

À chegada do instrutor, ele percebe o que ocorria com os sujeitos e intervém de forma a ajudá-los a superar a ansiedade do novo. Na etapa seguinte o grupo vivencia a posição depressiva, que é marcado pela elaboração psíquica e, por conseguinte, a superação daquelas ansiedades. A superação e elaboração é a tarefa implícita que deve ser cumprida a fim de se alcançar o objetivo final dado pela tarefa explícita. É nessa perspectiva que Pichon se refere ao grupo centrado na tarefa, pois a superação daquela cisão esquizoparonóide que o sujeito sente deve ser abordada e elaborada operando a tarefa.

Entendemos por elaboração (psíquica) o trabalho realizado pelo sujeito "com o fim de dominar as excitações que chegam até ele e cuja acumulação ameaça ser patogênica. Este trabalho consiste em integrar as excitações no psiquismo e em estabelecer entre elas conexões associativas" (LAPLANCHE \& PONTALIS, 1988, p 196, grifo nosso). 
O grupo deverá seguir esse caminho, de superação dos posiçãos esquizoparonóides, explicitando o implícito a fim de conseguir realizar a tarefa explícita o que significa superar o montante de ansiedade despertado por toda novidade para que se consiga atingir o seu objetivoconstruir a canoa.

Isso nos leva a pensar numa situação de ensino-aprendizagem, quando o professor solicita a um grupo de alunos resolverem alguma atividade. O que se imagina é que ela vai se caracterizar em uma tarefa simplesmente objetiva, pois é esperado que os estudantes quando estão na escola se separem de sua vida pessoal não deixando que os fatores subjetivos os atrapalhem (o mesmo é esperado do professor). Contudo, não é assim que acontece, dado que é impossível separar-se de tais fatores, já que eles são próprios do ser humano. Nessa mesma direção segue o pensamento de Bleger (2001), que ao iniciar sua exposição sobre grupos operativos de ensino afirma:

"Através de suas atividades, os seres humanos entram em determinadas relações entre si e com as coisas, além da mera vinculação técnica com a tarefa a realizar, e este complexo de elementos subjetivos e de relações constitui o seu fator humano mais especifico. (...) O grupo operativo trabalha sobre um tópico de estudo dado, porém, enquanto o desenvolve, se forma nos diferentes aspectos do fator humano. Embora o grupo esteja concretamente aplicado a uma tarefa, o fator humano tem importância primordial (...)" (p 59-60).

Dessa forma, o processo grupal sofre interferências dos aspectos subjetivos dos seus membros e entram em cena os objetos do mundo interno que tentam fazer uma leitura da realidade exterior. Nessa tentativa surgem as ansiedades básicas que são o medo da perda e do ataque (associadas ao posição esquizoparanóide). Medo de perder aquilo que já está estabelecido, consolidado e conquistado e o medo do ataque de algo que não se conhece, do que esta por vir, do novo. Essas ansiedades são mobilizadas sempre que o grupo se encontra diante de uma situação de mudança,

"Podemos resumir as suas finalidades e seus propósitos dizendo que a atividade está centrada na mobilização das estruturas estereotipadas, nas dificuldades de aprendizagem e comunicação, devidas ao montante de ansiedade despertada por toda a mudança (ansiedade depressiva por abandono do vínculo anterior e ansiedade paranóide criada pelo vínculo novo e pela insegurança). Essas duas ansiedades são coexistentes e cooperantes e, se forem intensas, poderão conseguir o fechamento do sistema (círculo vicioso)" (p. 134)

Devemos considerar ainda, que cada membro chega com sua história pessoal, isto é com sua verticalidade. Entretanto, à medida que vai se constituindo a rede vincular, seus membros partilham objetivos e necessidades comuns, e criam uma nova história, a horizontalidade, gerando assim uma identidade e especificidade própria da totalidade do grupo. 


\subsection{2-Os papéis}

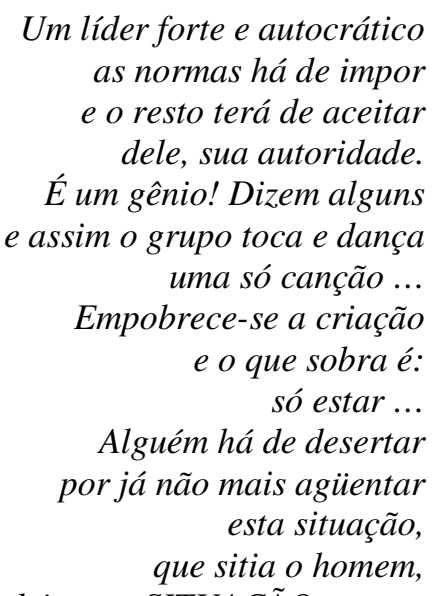
e o não o deixa em SITUAÇÃO estar...

Quando aquelas pessoas, do exemplo que utilizamos acima, faziam considerações sobre o cortar ou não a árvore, ou então quando criavam as estratégias de como fazê-lo, dizemos que eles assumiam papéis que se relacionam com o cruzamento da verticalidade do sujeito com a horizontalidade que se forma no grupo. Estão em jogo nesse momento processos de múltiplas transferências, projeções e identificações entre eles próprios e com a tarefa. Podem ser gerados vínculos de natureza diversos, tais como aqueles que apontamos anteriormente, e que vão de alguma maneira condicionar assunção do papel que será assumido ou atribuído a alguém. A rede vincular e, conseqüentemente, a rede de comunicação, serão constituídas em função dos papéis assumidos e adjudicados entre os membros do grupo. Nesse sentido, é possível dizer que o papel é uma função particular, própria do sujeito, que ele faz ou que tenta fazer chegar ao outro, através dos processos de transferências, projeções, etc. Isso implica em dizer que em nossa vida de relações sociais sempre assumimos e adjudicamos papéis aos outros (PICHON-RIVEIRE, 1994).

Dessa maneira, admitimos que em condições normais podemos assumir (e atribuir aos que convivem conosco) papéis diversos. Por exemplo, uma pessoa tem o papel de professor na escola, de pai em casa, de paciente num consultório médico, de cidadão dentro de um ônibus, amigo nas relações sociais. E a partir dessa idéia básica, podemos afirmar que:

"Estabelece-se um permanente interjogo entre o assumir e o adjudicar. Todas as relações interpessoais em grupo (...) são regidas por um permanente interjogo de papéis assumidos e adjudicados. Isto é, precisamente, o que cria a coerência entre o grupo e os vínculos dentro de tal grupo". (ibid, p. 128). 
Bem como:

"O papel adjudicado é o papel prescrito, ou papel necessitado no grupo, que deve ser cumprido por aquele que assume esse papel. Na medida em que os dois papéis coincidem - o prescrito e o assumido-, produz-se um encaixe, uma articulação" (PICHON-RIVIERE, 2005, p. 145).

No que se refere ao processo de assunção e atribuição de papéis, encontramos na teoria do vínculo de Pichon-Rivière (1994) o que ele chama de "Teria dos três D" que se refere ao depositário, depositante e o depositado ${ }^{12}$. O depositário é o objeto sobre o qual se situa o depósito, ou seja, em quem ou quê o sujeito faz a projeção de si ou de algo; o depositante é quem faz essa projeção; o depositado é o conteúdo transmitido nessa relação (CIAMPONE, 1998).

As configurações ${ }^{13}$ que são geradas a partir do interjogo de papéis não são estáticas e sofrem uma variação que depende do aqui-agora em que o grupo se encontra. Como dissemos, essa dinâmica está associada à assunção dos papéis, que se dá em uma relação de sujeito e objeto marcada pelas projeções, os quais Pichon aponta quatro como principais: porta-voz, líder, bodeexpiatório e sabotador.

O porta-voz surge diante de uma necessidade de anunciar ou denunciar um acontecer grupal; ele se torna porta-voz dos emergentes do grupo, isto é, ele traz à tona aquilo que está latente no grupo, que pode ser uma ansiedade, o medo de enfrentar a tarefa, ou ainda, pode indicar uma necessidade. Quem o assume, não tem consciência que enuncia, que traz como emergente algo da situação grupal, a qual ele vivencia como sendo próprio dele. De fato, se aquele sujeito se torna porta-voz é porque o conteúdo daquele algo (as ansiedades, as fantasias inconscientes) bem como a maneira como o traz está relacionado com a sua história de vida, sua verticalidade, enquanto que o fato de enunciá-lo num dado momento do processo grupal é devido à horizontalidade do grupo, o que significa que nesse sujeito conjugam-se essas duas dimensões. Isso em última análise é o que Pichon diz sobre o fato de o sujeito ser produzido no grupo.

No exemplo que trouxemos, quando um dos membros diz que a árvore não deveria ser cortada, argumentando que causaria danos ambientais, podemos interpretá-lo como o porta-voz do grupo que entra no posição esquizoparonóide, ou seja, essa sua fala é um emergente do grupo que vivencia essa ansiedade: a ansiedade é do grupo e não somente de quem a enuncia. É possível ainda, haver mais de um porta-voz, cujas palavras e ações compõem elementos mais complexos

\footnotetext{
${ }^{12}$ Esses nomes referentes aos três D nada tem a ver com as idéias freirianas sobre a educação bancária, mas como explicamos no texto, se refere aos processos de múltiplas transferências, projeções, identificações que ocorrem naquele interjogo de papéis que há em todo grupo (social).

${ }^{13}$ Nas próximas seções vamos abordar com mais detalhes sobre as configurações que podem ser geradas nos grupos durante a realização de uma tarefa.
} 
para serem decifrados e que os sujeitos no processo grupal assim se manifestam fazendo emergir o que está latente.

$\mathrm{Na}$ técnica operativa, o porta-voz tem uma importância fundamental na dinâmica grupal, pois é ele o veículo dos emergentes e o depositário das ansiedades do grupo que o coordenador - o professor no caso de um grupo de aprendizagem - se presta para interpretar o que está acontecendo e a partir daí fazer suas intervenções. Podemos, então, sintetizar essas idéias nas palavras de PichonRivière (2005):

"O porta-voz é aquele que, no grupo, diz algo, enuncia algo em determinado momento, e esse algo é o sinal de um processo grupal que até esse momento permanecera latente ou implícito, como escondido no interior da totalidade do grupo. Como sinal, o que o porta-voz denuncia deve ser decodificado, ou seja, é preciso retirar seu aspecto implícito. Este conceito é importante, por que é o aspecto da situação grupal que não emerge por si, mas através de um processo concreto que lhe dá possibilidades de emergir" (p. 257).

Quando o porta-voz enuncia algo, abrem-se duas possibilidades: ou os demais alunos encaram as dificuldades e passam a resolvê-las ou o grupo entende que esta dificuldade é somente daquele que a enunciou. No primeiro caso, o porta-voz vai se tornar o líder da tarefa e daí o grupo inicia um momento de cooperatividade. No entanto, se o porta-voz não é ouvido, ela passa a ser o bode-expiatório do grupo e os demais alunos passam a hostilizá-los de modo sutil, pois não reconhecem sua mensagem.

Trata-se do processo natural de assunção e atribuição de papéis em que um dos membros se faz depositário dos aspectos negativos do grupo ou da tarefa, "num acordo tácito no qual tanto ele [o que assumiu o papel de bode-expiatório] como outros componentes estão comprometidos" (ibid, p. 180), e cuja conseqüência são os mecanismos de segregação, ainda que de forma velada. Mas por outro lado, um outro sujeito, pelo mesmo processo, pode se fazer depositário dos aspectos positivos do grupo, sendo-lhe atribuído o papel de líder. No entanto:

“(...) ambos os papéis, o de líder e o de bode expiatório estão intimamente ligados, já que o papel de bode-expiatório surge como preservação da liderança, através de um processo de dissociação ou splitting, necessário ao grupo em sua tarefa de discriminação" (ibid).

Há ainda o papel do sabotador, que surge quando o nível de ansiedade é tal que fugir da tarefa lhe parece mais agradável do que ter que realizá-la criando outras necessidades como mais importantes e tentando levar o grupo a seguir seus passos. O sabotador torna-se o líder da resistência à mudança. Tanto o líder sabotador quanto o líder operativo não atuam sozinhos, eles têm os seus partidários que vão atuar na formação de subgrupos e assumir a bandeira do progresso da tarefa ou da sua sabotagem. A conseqüência dessa formação é um possível trânsito de alguém de 
um subgrupo ao outro, que nos permitirá medir a coesão do grupo, em virtude da quantidade de pessoas que passa de um a outro subgrupo.

No caso do líder, ele pode ser classificado em quatro tipos diferentes: democrático, autocrático, demagógico ou laissez-faire. O líder democrático vai ajudar o grupo a sair de uma situação dilemática; o segundo vai atuar como um tirano, dando ordens ao grupo; o demagógico vai atuar como um impostor mantendo uma aparência democrática, enquanto o último, laissez-faire, é aquele que não assume nenhum compromisso diante do grupo. Aqui nos reportamos às estrofes do poema supramencionado, ao mencionar os tipos de liderança no grupo.

Todo o processo de assunção de papéis é dinâmico e à medida que o grupo aprende a lidar com as situações de conflito vai caminhando para a operatividade. Isso significa que, na técnica operativa cada sujeito deve exercer um papel funcional e, além disso, o líder do grupo nada mais é do o especialista na função que necessitada em um momento específico da tarefa, ou seja, "o cozinheiro é o líder do grupo enquanto cozinha" ${ }^{14}$.

\subsection{3-Entre a fusão, com-fusão e situação: as fases do processo grupal}

A realização das atividades em grupo é marcada por fases que se referem a uma estrutura de linhas de ação do sujeito que permite ao coordenador um posicionamento diante dos problemas que lhes apresentam. Essas fases para Pichon são três: pré-tarefa, tarefa e projeto. O estabelecimento delas "apresenta-se numa sucessão evolutiva, e seu surgimento e interjogo constante podem situarse diante de cada situação ou tarefa que envolva modificações no sujeito" (PICHON-RIVIĖRE, 2005; p.33). Cada fase nos mostra uma configuração do pensar, sentir e agir do sujeito, cuja integração é necessária no processo de aprendizagem.

Na pré-tarefa é o momento em que há o domínio das técnicas defensivas, há uma resistência à mudança que é mobilizada pela presença das ansiedades básicas do medo da perda e do ataque, que ao se intensificarem passam a atuar como "obstáculo epistemológico na leitura da realidade" (ibid) estabelecendo um aumento da distância entre o real e fantasiado. Surge "como campo no qual o projeto e a resistência à mudança seriam as exigências de sinais opostos e criadoras de tensão" (ibid., p. 34) e que por conta disto o grupo começa a operar "como se" estivesse na tarefa, ou seja, tudo é feito "como se" estivesse realizando o trabalho especificado.

Relembrando o caso do grupo incumbido de construir uma canoa, notamos que os membros do grupo vivenciam uma experiência de cisão e ruptura (esquizoparonóide) no momento em que

\footnotetext{
${ }^{14}$ Trata-se de uma citação de Pichon em uma aula do curso de atualização docente, cuja publicação se encontra originalmente no periódico Ilusão Grupal $n^{\circ} 2$. No entanto, a referência que encontramos diz respeito ao texto "Técnica de observación de grupos operativos" disponível em www.psicologiagrupal.cl/documentos/articulos/observar.htm
} 
cortam a árvore, mas ainda devem construir a canoa. Trata-se da fase da pré-tarefa, porque há a prevalência das ansiedades básicas, com grande possibilidade de se desviar da meta estipulada. O grupo está, nesse momento, fragmentado e como conseqüência ocorre a dissociação entre o pensar, sentir e agir, como parte dos mecanismos de defesa. Observa-se ainda que, o grupo busca resolver os novos problemas com esquemas antigos cujo conhecimento lhes dá segurança diante dessa nova situação.

A fase da tarefa "consiste na abordagem e elaboração das ansiedades e na emergência de uma posição depressiva, na qual o objeto de conhecimento se torna penetrável” (ibid., p.35). Em outras palavras, é o momento quando o grupo torna-se capaz de perceber e controlar as ansiedades básicas; quando se pode trabalhar mais diretivamente em função da construção da canoa, seguindo o exemplo, e se desvinculando da árvore que não existe, a qual ainda eles estavam presos.

"Na tarefa, aquela posição depressiva requer elaboração, processo cuja significação central está em tornar 'consciente o inconsciente'; (...) o sujeito apareceria com uma 'percepção global' dos elementos em jogo, com a possibilidade de manipulá-los e com um contato com a realidade no qual, por um lado, (...) situa-se como sujeito, e por outro, lhe é possível elaborar estratégias e táticas mediante as quais pode intervir nas situações (projeto de vida), provocando transformações" (ibid).

O grupo experimenta com isso uma série de modificações que por sua vez vão tornar a situação nova para o mesmo, iniciando todo o processo como numa espiral, que opera um movimento circular, mas ao retornar ao ponto de partida, estará como que um plano acima (veremos a seguir esse modelo espiral). Com este modelo Pichon quer explicar como se dá a passagem da pré-tarefa para a tarefa em que "o sujeito efetua um salto, ou seja, a acumulação quantitativa prévia de insight realiza um salto qualitativo durante o qual o sujeito se personifica e estabelece uma relação com o outro diferenciado" quando alguém passa a situar-se no grupo em relação ao outro (ibid). Então, a modificação de que estamos tratando tem um duplo sentido, a partir do sujeito e para o sujeito, o que acarreta a constituição de um vínculo.

É importante mencionarmos o fato de que o termo "tarefa" é usado tanto para expressar o objetivo (tarefa explícita) de um grupo quanto os momentos de centrar-se nesse objetivo, vencendo a fragmentação do vínculo, tal qual descrevemos acima. Isso significa dizer que o processo grupal leva a apropriar-se do que se propôs como Tema, (como tarefa explícita) através de centrar-se no próprio Tema ${ }^{15}$.

\footnotetext{
${ }^{15}$ Essa argumentação foi dada por Armando Bauleo, companheiro de Pichon, em uma conferência em Madri, no ano de 1979, quando já se tinha uma reflexão mais amadurecida das idéias sobre o grupo operativo. O texto se encontra em: Bauleo, A (comp.), Grupo Operativo y Psicologia Social, Montedevideo, Uruguay: Imago, 1979. Não colocamos essa referência com as demais porque não a consideramos como principal.
} 
A Fase do projeto se dá quando o grupo como um todo atinge a pertença entre seus membros, mostrando que de certa forma o grupo já aprendeu como superar os obstáculos, os quais são conseqüências das ansiedades básicas de perda e ataque. O grupo nesse momento já é capaz de fazer um planejamento e propõe objetivos para além do "aqui e agora".

Pichon-Rivière (2005) afirma que nesse "aqui e agora" é possível perceber o projeto que “como todo mecanismo de criação, está destinado a superar a situação de perda [morte do grupo] que os membros vivenciam quando através da realização da tarefa, percebem a possibilidade da separação ou finalização do grupo" (p 181). Isso é como se os sujeitos deslocassem para o futuro o desejo de permanecerem juntos para evitarem pensar que o grupo pode acabar e assim suportar essa angustia gerada pela proximidade da "morte" do grupo (certamente tudo isso ocorre no nível do inconsciente). Se pensarmos no exemplo da canoa, a fase do projeto seria quando eles passam a planejar se a canoa vai afundar ou não, o que significa que estabeleceu-se um novo objetivo diferente daquele que os organizou como grupo.

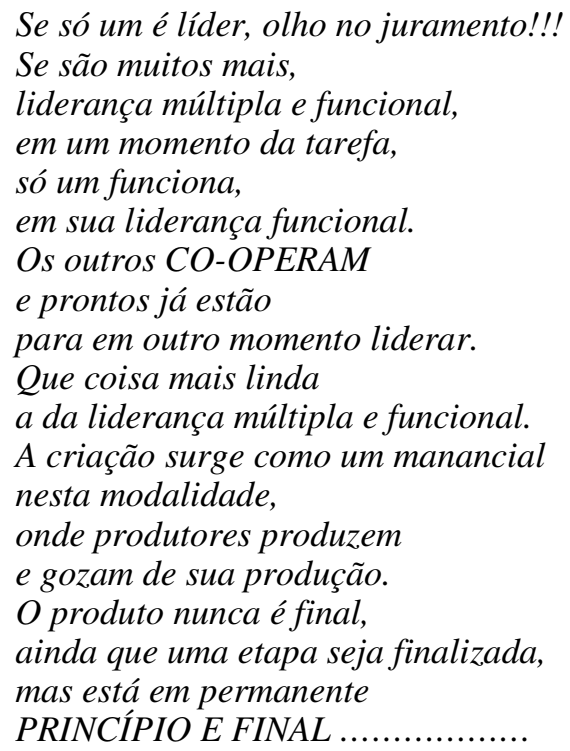




\title{
3.4.4-...avaliação, de novo recomeçar: cone e vetores
}

\author{
Os sujeitos não são hoje \\ o que foram ontem \\ e o que serão amanhã. \\ De sua mudança são responsáveis \\ e juntamente com os demais, a produzem. \\ Porque não há coisa mais linda \\ do que sermos produtores de NOSSA PRODUÇÃO. \\ Os outros nos mostram nossas mudanças, \\ nós lhes mostramos as suas. \\ Porque este é o momento da AVALIAÇÃO. \\ É de novo RECOMEÇAR. \\ Porque tornar a começar (ou recomeçar) \\ não é o mesmo que o começo. \\ Já na avaliação, diferentes nos vimos \\ e apesar de podermos ser os mesmos, \\ ESTAMOS DIFERENTES. SOMOS DIFERENTES.
}

Toda a dinâmica de funcionamento deve seguir uma trajetória dialética, em que os problemas e conflitos são resolvidos no e pelo próprio grupo, caracterizando as fases que descrevemos anteriormente. Estas não ocorrem de forma linear, ou seja, ao passar da pré-tarefa para tarefa e seguindo para o projeto, segue-se um interjogo entre elas, em que a cada situação nova o grupo volta para um ponto inicial, o que significa que o grupo chegou num momento de síntese. Este se configura numa nova situação quando os sujeitos vão passar pelas posições esquizoparonóide e depressiva, superando os obstáculos provenientes da tarefa e chegando a uma outra síntese, que por sua vez representa uma nova situação. O grupo deverá então seguir essa trajetória a fim de se tornar operativo e entrar na fase do projeto, que não significa ausência da prétarefa e sim sua superação mais rapidamente.

Pichon nos indica com isso que o grupo seguirá assim do implícito para o explícito, numa trajetória em espiral, representado por ele como um cone invertido apresentado na figura 6, partindo-se da ponta inferior para a parte superior. Dessa forma, as fases que o grupo atravessa indicam os momentos desse processo dialético, em que a principal característica é o fato da quantidade transformar-se em qualidade, por meio de saltos sucessivos (tese, antítese e síntese).

Ao pensarmos no modelo de uma espiral para representar o processo grupal, poderíamos imaginá-la como uma mola vertical ao invés de um cone invertido como o de Pichon, pois da mesma forma estaríamos representado aqueles saltos qualitativos do processo dialético. A diferença entre a mola e o cone reside no fato que a primeira tem os raios constantes, enquanto no cone o raio aumenta à medida que muda de plano, subindo a espiral. Isto nos dá a idéia de que nesse processo quando o aluno experimenta um salto qualitativo há também um "acúmulo" quantitativo em sua aprendizagem. Quando o grupo não consegue dar os saltos qualitativos os seus membros 
experimentam uma situação de estereotipia e ao invés de uma espiral, permanecem em um círculo fechado.

A partir da observação de determinados comportamentos grupais, Pichon-Rivière (2005) propôs uma escala de avaliação dessa dinâmica relacional que ele descreveu indicando os vetores de avaliação que são os sete a seguir:

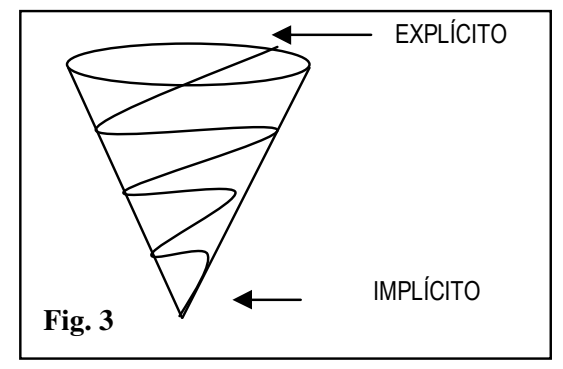

Fig. 3- Cone invertido indicando o processo dialético da aprendizagem.
Os sujeitos não são hoje

o que foram ontem

e o que serão amanhã.

De sua mudança são

responsáveis

e juntamente com os demais,

a produzem.

Porque não há coisa mais

linda

do que sermos produtores de

NOSSA PRODUÇÃO.

Os outros nos mostram

nossas mudanças,

nós lhes mostramos as suas.

- Afiliação: momento pelo qual todo grupo atravessa, no qual os seus membros estão se conhecendo e estabelecendo os primeiros contatos com a tarefa. Há, portanto, um envolvimento distanciado dos sujeitos aí envolvidos.

- Pertença: à medida que o grupo se desenvolve, aquele distanciamento da tarefa e dos demais membros vai diminuindo e o grupo passa a ter um sentimento de afiliação mais intenso. Surge, então, a possibilidade de o grupo elaborar uma estratégia, uma tática, uma técnica e uma logística, ou seja, é nesse momento em que se torna possível o planejamento para a abordagem da tarefa explícita. Como conseqüência, ocorre uma maior identificação com os processos grupais e os membros passam se sentir com um integrante; há um clima de segurança que favorece a tarefa.

- Cooperação: Consiste em uma fase em que há uma contribuição interpessoal na direção da tarefa, mas é ainda feita de forma silenciosa. É neste momento que os membros começam assumir os diferentes papéis e de forma complementar, ou seja, os membros co-operam no e para o grupo. Isto significa que a rotação de papéis leva da heterogeneidade dos membros à homogeneidade da tarefa, manifestando-se assim o caráter interdisciplinar do grupo e o interjogo da verticalidade e da horizontalidade.

- Pertinência: indica o sentir-se e colocar-se direcionalmente sobre a tarefa prescrita. Este momento é uma fase intermediaria em direção da tarefa e do projeto. Instala-se 
neste momento um "como se" estivesse na tarefa. Porém, o grupo não se encontra totalmente na pré-tarefa, pois há uma integração entre o pensar, sentir e agir.

- Comunicação: é um vetor fundamental de integração grupal. Há um apontamento não somente para o conteúdo da mensagem, mas também como se veicula a sua transmissão, quais os sinais e ainda como vai se constituindo a vinculação entre o emissor de uma mensagem e o seu receptor. Tudo isto ocorre através dos processos de codificação e decodificação da mensagem. A comunicação em um grupo operativo mostra o grau de dificuldade do grupo revelando as estereotipias que dificultam a aprendizagem e formação de novas condutas.

- Aprendizagem: esta se desenvolve através de um processo dialético (tese, antítese e síntese) quando o grupo consegue dar saltos qualitativos, indicando assim que houve uma mudança da realidade deste sujeito. Isto em certa medida envolve a resolução das ansiedades e uma adaptação ativa á realidade.

- Telê: refere-se ao clima e a disposição grupal. Reflete-se a transferência tanto positiva quanto negativa que se dá entre os membros do grupo e entre estes e o professor, que é o coordenador do grupo.

$\mathrm{Na}$ técnica operativa o vetor comunicação tem um aspecto importante, pois tanto de forma verbal ou gestual, é possível identificar os emergentes do grupo, que são fundamentais para a intervenção que o coordenador deverá fazer. O processo de comunicação é definido por Pichon (2005) como "a emissão de uma série de sinais, de um intercâmbio entre um emissor e um receptor, com um processo de codificação e decodificação" (p. 269).

A esse sistema agrega-se, porém, um ruído produzido por um terceiro na comunicação entre os membros do grupo gerando aquele obstáculo epistemológico, que pode transformar a espiral dialética em um círculo fechado (PICHON-RIVIÈRE, 2005). A presença desse terceiro em nível do vínculo e do diálogo gera distúrbios tanto da comunicação quanto da aprendizagem que levará Pichon a afirmar que "todo vínculo como mecanismo de interação, deve ser definido (...) ao mesmo tempo bicorporal e tripessoal" (ibid., p. 11). O terceiro de quem estamos tratando se refere a um Outro a quem se prestam contas, que pode ser o professor (SILVA \& VILLANI, 2006; ibid, 2008), ou a própria instituição onde o grupo está sitiado.

Para esclarecer vamos usar o exemplo do telefone. Nesse sistema, duas pessoas falam, o que significa que há um emissor, um receptor e um canal de comunicação. Enquanto conversam, ouvese um ruído produzido por um terceiro sujeito- ambos presumem que há "boi na linha". Para manterem a conversa, inicia-se uma fala em códigos, para evitar que esse suposto terceiro venha decifrar a sua mensagem. O que presumimos é que toda a comunicação foi alterada e codificada em 
função desse terceiro, a quem nos referimos no parágrafo anterior como Outro (a quem se prestas contas) e, por conta disto, a comunicação torna-se um sistema mais complexo e de difícil compreensão por parte do coordenador do grupo.

Como efeito colateral da presença do ruído na comunicação, a aprendizagem também sofrerá interferências, pois a mudança a que se almeja ficará estancada. Dessa forma,“a possibilidade de abordar um objeto, de apoderar-se instrumentalmente de um conhecimento, para poder operar com ele e conseguir uma incorporação" fica prejudicada (PICHON-RIVIÈRE, 2005, p. 270).

Por fim, a figura da espiral nos indica a concepção pichoneana de aprendizagem, que Bleger providencialmente afirma:

"O termo aprender está bastante contaminado pelo intelectualismo; assim, concebe-se o processo como a operação intelectual de acumular informação. Outra definição ainda que correta em certo sentido, traduz a aprendizagem em uma linguagem reducionista e afirma que é uma modificação do sistema nervoso produzido pela experiência. Preferimos o conceito de que a aprendizagem é modificação mais ou menos estável de linhas de conduta, entendendo-se por conduta todas as modificações do ser humano, seja qual for a área em que apareçam; neste sentido pode haver aprendizagem ainda que não tenha a sua formulação intelectual"(p. 68).

\subsection{5-Sistemas de comunicação}

Um sistema de comunicação em grupo é complexo no sentido de que além daquilo que é explícito há a codificação da mensagem devido à presença de um terceiro. Admitimos também que a constituição dessa rede se deve à assunção e à adjudicação dos papéis, que são processos de projeções e transferências realizadas no setting grupal.

O que descrevemos a seguir trata-se de algumas dessas possibilidades de configurações do sistema de comunicação que vamos representá-las graficamente por meio das figuras a seguir. Esse tipo de elaboração nos parece um instrumento importante e será utilizado como instrumento na análise do processo dos grupos que deste trabalho. Para a construção de tais configurações estamos considerando a comunicação verbal, sem, no entanto, reduzi-la somente a esse nível de expressão.

Uma primeira configuração que o grupo pode experimentar é o sistema de comunicação convergente que é assim denominado, porque os canais de comunicação convergem para um dos membros do grupo. O que significa que todos se comunicam somente com o aluno 1, como apresentado na figura 7, podendo estabelecer com ele um vínculo positivo (reconhecendo sua liderança naquele momento) ou negativo (colocando-o como bode expiatório). Quando caracterizamos o grupo dessa forma, facilitamos de certa maneira a identificação dos papéis 
assumidos pelos alunos; isso constitui uma tarefa importante do professor para evitar que se estabeleça entre os alunos um congelamento dessa configuração. Veremos mais adiante ao analisarmos os grupos exemplos dessa configuração.

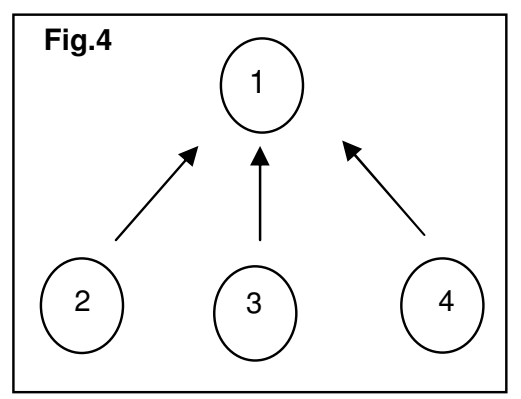

Fig. 4- Sistema de Comunicação Convergente indicando assunção do papel de líder ou do bodeexpiatório

Ao contrário do primeiro caso, quando encontramos um sistema de comunicação divergente (Fig. 4) a comunicação parte de um para todos. Nessa configuração identificamos outras duas possibilidades: assunção do papel de porta-voz ou do líder (autocrático). O primeiro é aquele que denuncia um acontecer grupal, é ele que em um dado contexto vai se colocar em destaque no grupo para falar-lhe algo. No entanto, esse destaque entre os membros do grupo pode ser assumido por um líder do tipo autocrático de quem sai uma voz de comando para os alunos: "Vamos todos fazer o exercício!" ou ainda "Escreva o que eu estou falando!" (veremos uma situação similar na análise dos dados). A diferença entre os dois tipos de comunicação está em quem tem a iniciativa.
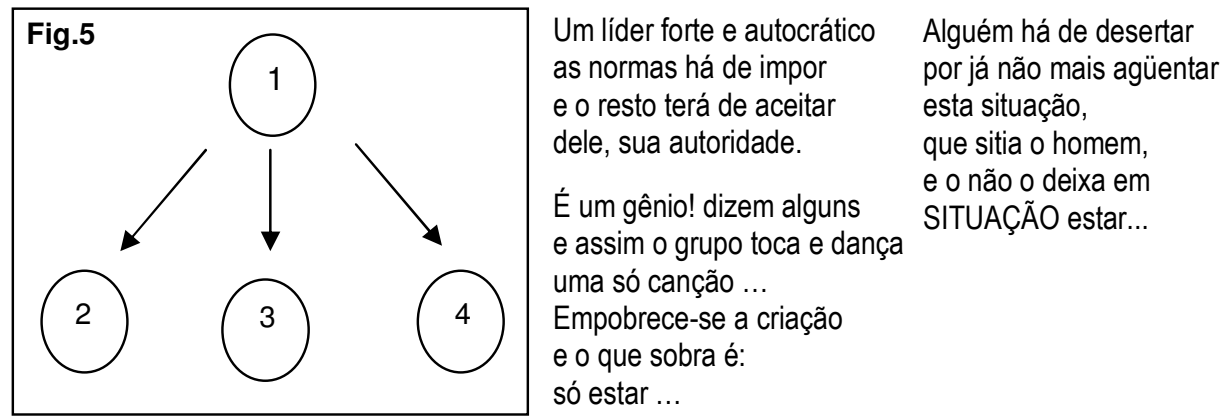

Fig. 5- Sistema de Comunicação Divergente, a mensagem parte do aluno 1 os demais membros do grupo. (Trecho do poema que estamos usando para ilustrar o nosso texto)

Fica mais clara essa idéia se usarmos novamente a analogia de linhas de telefone: na figura 4 quem abre os canais de comunicação são os alunos 2, 3 e 4. Na figura 5, que inicia a chamada é o aluno 1. Dessa forma, o sentido da seta indica de quem parte a chamada. Há, entretanto, um sistema intermediário entre a convergência e a divergência, no qual a iniciativa da comunicação está de ambos os lados, que é o exemplo mostrado na Fig. 6. 


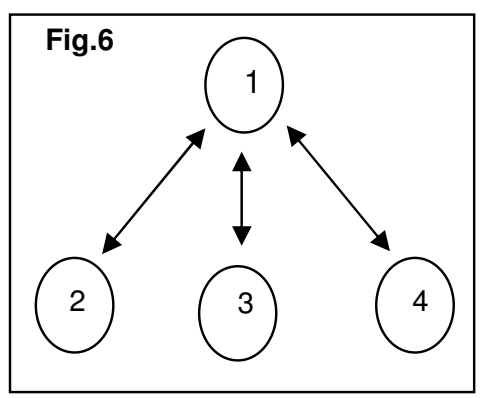

Fig. 6- Os canais de comunicação são estabelecidos somente entre os subgrupos indicados.

Essas configurações devem ser dinâmicas e seguir sempre uma trajetória dialética, tal como já indicamos. Se os sistemas anteriores prevalecem no processo grupal significa que o grupo está com problemas e que os papéis não estão circulando entre os membros. Nesse sentido, os sistemas convergente e divergente podem indicar uma situação mais estereotipada do que o representado na figura 6. Neste há aberturas de canais simultâneas, mas que não são de todos para todos.

Para que a situação de estereotipia seja quebrada é necessário que o próprio grupo trabalhe nesta direção, pois isto constitui parte da tarefa implícita que é necessário cumprir. No entanto, muitas vezes, é preciso a intervenção do professor para perturbar ${ }^{16}$ a rede de comunicação a fim de favorecer uma nova situação, na qual os papéis comecem a circular. Assim, quando o professor chega ao grupo ele deve abrir canais de comunicação com todos os estudantes e, além disso, perceber os pedidos de abertura que vem dos alunos e quais são as mensagem que estes estão lhe enviando, bem como se deve tentar decodificar as mensagens que ali circulam. Então, com o professor presente no grupo, podemos encontrar uma nova configuração que representamos pela Fig. 7 (a-b).
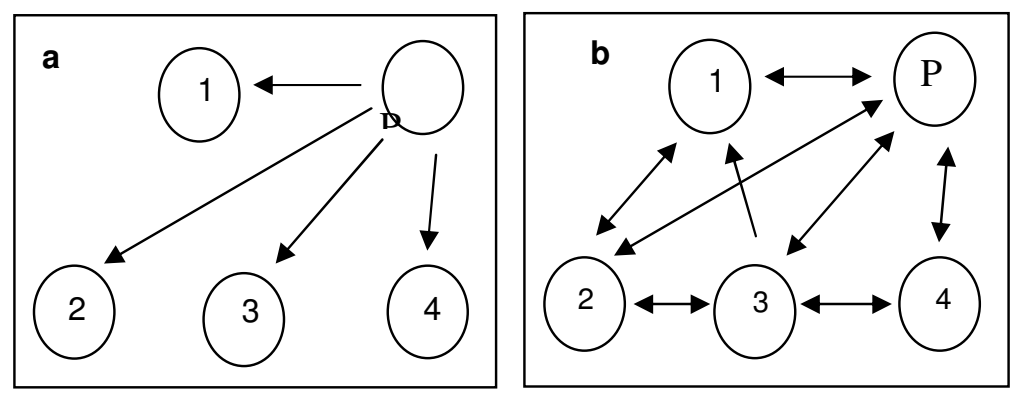

Fig. 7- a) o professor chega ao grupo e abre canais de comunicação com todos os membros; b) durante a sua intervenção outros canais de comunicação vão se abrindo dentro do grupo.

Após a saída do professor uma nova situação deve ser gerada se a sua intervenção favoreceu uma quebra da estereotipia. A comunicação do grupo deve se estabelecer de forma a gerar um sistema de comunicação difusa, em que há uma interação entre todos os membros do grupo, indicando a fluidez na comunicação, a elaboração das ansiedades básicas, a abordagem da tarefa

\footnotetext{
${ }^{16}$ (essa perturbação não é no mesmo sentido do que falávamos anteriormente, quando nos referíamos ao terceiro na comunicação)
} 
explícita e a circulação dos papéis. Neste caso não há um canal privilegiado como nos anteriores. A Fig. 7 nos mostra esta configuração.

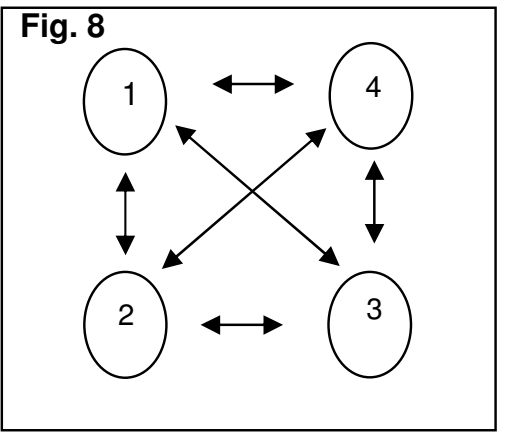

Fig. 8- A comunicação nesta configuração é difusa entre os membros do grupo.

Quando o grupo supera um momento de conflito (tese e antítese) uma nova situação é gerada: a síntese anterior se torna agora ponto de partida para um novo acontecer grupal. Nesse momento o nível de ansiedade pode bloquear os membros do grupo e gerar uma nova situação de estereotipia, podendo o grupo voltar a experimentar uma comunicação convergente (ou divergente), conforme nos mostra a figura 9.

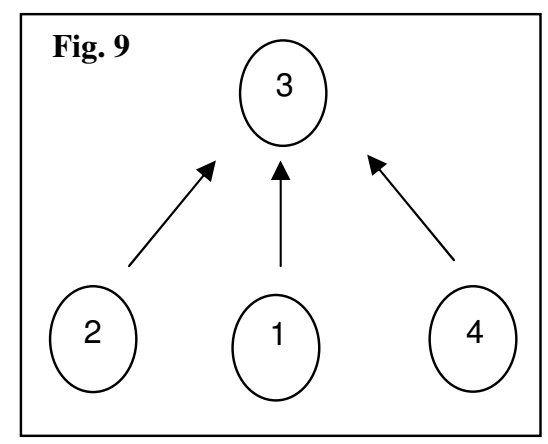

$$
\begin{gathered}
\text { Os homens em situação, } \\
\text { terão de passar pela } \\
\text { confusão } \\
\text { que é o caminho da fusão } \\
\text { Dele sairão } \\
\text { com normas a comunicar } \\
\text { EM PERMANENTE E } \\
\text { DIALÉTICA }
\end{gathered}
$$

Fig. 9- O grupo experimenta uma nova situação de convergência voltada par a aluno 3 o que difere da primeira configuração (Fig. 4).

Na configuração 9, quem assume o papel do líder (ou de bode-expiatório) é outro aluno, mostrando de alguma forma que houve uma circulação dos papéis e um salto qualitativo ao passar da pré-tarefa para a tarefa. Se, contudo, o grupo permanecer nesse sistema, há a necessidade de uma nova intervenção do professor para poder perturbar novamente a rede de comunicação saindo de um sistema convergente para uma rede difusa, evitando que aquela se congele e volte à estereotipia.

Quando o grupo se encontra diante de uma nova situação. 


Porque tornar a
começar (ou
recomeçar)
não é o mesmo que o
começo.
Já na avaliação,
diferentes nos vimos
e apesar de podermos
ser os mesmos,
ESTAMOS
DIFERENTES.
SOMOS
DIFERENTES.
Uma tarefa cumprimos
e nela nos conhecemos.
Sei quem você é para
mim
trabalhando nesta
tarefa.

Porque tornar a

não é o mesmo que o

começo.

diferentes nos vimos

e apesar de podermos

DIFERENTES.

SOMOS

DIFERENTES

Uma tarefa cumprimos

Sei quem você é para

trabalhando nesta

tarefa.

\author{
Sei que você será \\ diferente \\ trabalhando outra \\ tarefa ... \\ (...) \\ De novo a fusão, \\ a con-fusão \\ e esses dois caminhos \\ $\cdots$ \\ De novo a \\ organização, \\ Olho no juramento! \\ Seguramente iremos \\ roçá-lo \\ porque não há coisa \\ mais tentadora \\ do que estar \\ juramentados.
}

\section{5-O coordenador do grupo e as suas intervenções}

Para Pichon-Rivière há uma "regra de ouro" da técnica de grupos operativos no processo de aprendizagem, que fala que esta se estabelece quando é possível regular uma distância do objeto de conhecimento, ou seja, existe uma distância ótima que corresponde a uma ansiedade ótima, acima ou abaixo da qual a aprendizagem fica prejudicada. E para ajudar o grupo no controle dessa ansiedade ótima, é preciso que as intervenções do coordenador sejam nesse sentido.

Naquele exemplo da árvore e da canoa, o grupo experimentava um montante de ansiedade capaz de paralisá-lo. As lideranças operativas devem surgir entre os membros para ajudá-los a sair dessa situação, mas nem sempre isso ocorre. Como apontamos na seção anterior, as intervenções do professor ganham um destaque especial no processo de aprendizagem, pois ao atuar no grupo, ele é capaz de favorecer a comunicação, fazer circular os papéis e assumir quando for o caso aquela liderança operativa no grupo. Nesse sentido, nesta seção procuramos abordar tal questão a fim de pensar as formas que essas intervenções podem assumir.

\subsection{1-Intervenções do professor no grupo.}

O trabalho com grupos nos ambientes de ensino-aprendizagem modifica substancialmente a dinâmica destes ambientes, bem como os objetivos que se deseja alcançar quando se propõe este tipo de organização. Quando trabalhamos com grupos 
nas aulas de Física buscamos meios de evitar que os alunos se mantenham dispersos por muito tempo com a predominância da pré-tarefa. Então, se, por um lado, optamos por uma forma mais rígida de se manter o controle do grupo, corremos o risco de limitar a sua criatividade, por outro, quando flexibilizamos demais algumas regras há o risco do grupo não conseguir sair dos níveis iniciais de funcionamento. Buscar aquela regra de ouro torna-se uma tarefa difícil para o professor!

Como cada grupo escreve sua história, o professor deve tentar respeitar estas suas características peculiares sem pretender forçar a operatividade nem seu rendimento, possibilitando ao grupo trabalhar da melhor forma que ele pode e consegue. Nas suas intervenções o professor tenta equacionar a situação descrita no parágrafo anterior: favorecer a operatividade do grupo sem limitar a sua criatividade.

Barros (2002) afirma que "os fenômenos grupais se tornam inteligíveis ao observador que consente em participar da vivência grupal (...); tais fenômenos não podem ser observados 'de fora', assim como também não podem ser vistos como fragmentos a serem analisados posteriormente"(p.19), já que as ações e percepções dos membros pertencem a um conjunto mais complexo que é difícil compreender para quem está de fora desta estrutura. Portanto, nesse processo não podemos negligenciar o fato de que o professor se torna um membro do grupo assumindo algum papel que lhe é atribuído na relação com os alunos. Por outro lado, não podemos negar o fato de que o professor exerce uma função normativa; e ainda, não podemos desprezar o fato de que o professor pode ser considerado pelo grupo como o terceiro nas suas relações, Buscamos neste momento caracterizar as intervenções do professor de acordo como se estabelece sua relação com os alunos: institucional e presencial e virtual.

\section{a) Intervenção Institucional}

Pensando na escola como um tipo de grupo secundário, cada sujeito, professor, aluno, diretor, etc. exerce papéis diferentes, pois cada um possui uma tarefa específica dentro dessa grupalidade. Então, no que diz respeito ao professor, entre tantas outras, é sua função dar tarefas aos alunos, e quando ele o faz, no ambiente de aprendizagem, intervém no grupo de forma institucional.

Chamamos então de intervenção institucional aquela em que o professor age exercendo o seu papel como pertencente aquele grupo secundário, ou seja, ele age de forma institucional quando, por exemplo, em sala de aula convoca os alunos para se 
reunirem em grupos, dando-lhes um exercício ou outra atividade para ser feita. Bleger (2001) ainda afirma que "a forma de tratar o tema é o conteúdo normativo da tarefa" (p. 93). Dessa forma, relacionamos o aspecto normativo à intervenção institucional que assume uma peculiaridade em nosso caso por causa das funções (Líder, Anotador e Questionador) que foram outorgadas aos alunos como forma de se abordar a tarefa explicita.

Contudo, associamos essa normatização das atividades do grupo ao enquadre, dizendo que era necessário para que o grupo passasse da confusão para a organização. Reafirmamos assim, que o estabelecimento "dos parâmetros a serem mantidos [nas aulas], como elementos fixos durante o contrato" (CIAMPONE, 1998, p. 120) se configura como uma intervenção institucional no grupo.

\section{b) Intervenção Presencial}

O enquadre, aspecto normativo da tarefa, não oferece garantias do funcionamento do grupo e se somente esse aspecto for considerado ele pode limitar a criatividade dos alunos. Torna-se necessário regular sua manutenção para proporcionar a operatividade dos trabalhos grupais e para isto, o professor precisa favorecer a comunicação e promover a circulação dos papéis. Isso implica que ele deve "ajudar na constituição, no desenvolvimento e na manutenção do grupo- como equipe de trabalhoassumindo uma liderança democrática" (FERNANDES, 2003, p. 201), sem, no entanto, deixar que a comunicação sempre convirja para si. É, sobretudo, nesse processo de manutenção do enquadre que os alunos lhe atribuem outros papéis (bode-expiatório, sabotador ou líder), dependendo de como se estabelece a relação do grupo com o professor.

As intervenções presenciais devem ter ainda um caráter de assinalação e interpretação. Assinalar significa apontar e descrever as situações que o grupo está vivenciando e interpretar é no sentido da criação de hipóteses para a compreensão do que ocorre entre os alunos. O conjunto dessas duas formas de abordagem busca trazer à tona o que está implícito e latente. O que caracteriza essa forma de intervenção é essa relação em que ocorrem fortemente os processos de transferência, projeção e identificação, típico das relações entre os sujeitos (CIAMPONE, 1998; LAPLANCHE \& PONTALIS, 1988; VILLANI, 1999). 
A incorporação de tais idéias nos leva a pensar que será função do professor "estimular a participação dos integrantes, esforçando-se por integrar as experiências sucessivas, os emergentes, indagando o implícito, intervindo no processo grupal quando necessário" (CIAMPONE, 1998, p. 131). É preciso estar atento também para as mensagens que ele recebe dos alunos, pois como vimos, esse processo de comunicação torna-se complexo ao pensar que se estabelece de forma "bicorporal e tripessoal" Para além daquelas duas formas de atuação no grupo, o professor:

“(...) deve procurar facilitar o diálogo e estabelecer a comunicação, incluindo-se aqui o respeito aos silêncios produtivos, criadores, ou que signifiquem certo insight e elaboração; deve ajudar o grupo a sair dos estereótipos, do já conhecido; deve fazer o possível para estabelecer o diálogo entre os membros do grupo e não encampar tudo e nem centrar tudo". Enfim, "pode-se resumir as qualidades do coordenador em três palavras: arte, ciência e paciência" (BLEGER, 2001, p94-96).

Em suma, quando o professor se encontra no grupo, deve interagir e se comunicar de forma clara e verbal, assinalando e interpretando; atuar junto aos estudantes a fim de favorecer a comunicação entre eles; e perturbar uma possível rede de comunicação estereotipada, na qual a circulação de papéis estaria ameaçada. Nessas intervenções, o professor deve ajudar o grupo a experimentar saltos qualitativos sucessivos dentro do processo dialético de aprendizagem ou até mesmo, assumir o papel de líder do grupo (democrático ou autoritário) podendo surgir configurações do tipo convergente ou divergente. No capítulo da análise veremos alguns exemplos dessas intervenções do professor.

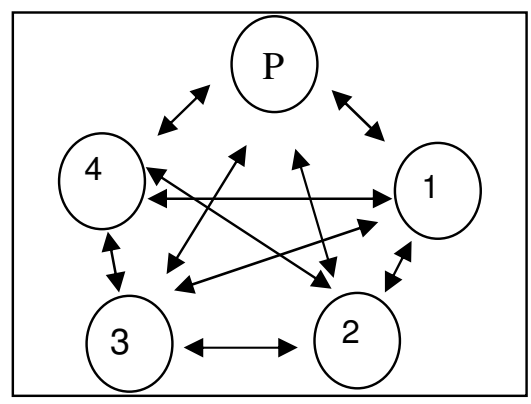

Fig. 10- Professor presente no grupo reajustando a rede comunicação. 


\section{c) Intervenção Virtual}

Entendemos por intervenção virtual como aquela em que o professor não está presente fisicamente, mas sua presença se faz como um ruído na comunicação dos alunos, cuja consequiência mais direta pode ser a dependência do grupo em relação a ele. Ela pode ocorrer devido aos dois tipos de intervenção anteriores, marcando os alunos com uma ação, que pode ajudar ou não o grupo no processo dialético de aprendizagem. Como característica dessa intervenção, os alunos passam a operar "como se" estivesse fazendo a tarefa, tal como na pré-tarefa.

Se o grupo passa a operar como se, podem surgir duas conseqüências: 1) o grupo passa a ser dependente do professor, cuja presença se dá como ruído; 2) o grupo usa essa virtualidade do professor como "objeto transicional" para suportar os montantes de ansiedade e efetuar os saltos qualitativos.

A dependência é gerada no grupo como forma de atuação e abordagem da tarefa explícita, dado que grupo age assim cumprindo os passos que o professor determinar Por essa razão, os membros do grupo atuam como se estivessem abordando a tarefa, pois na verdade não poderiam pensar diferentemente, porque isso representaria uma traição e por conta disso não teriam a ajuda e o apoio do professor. Em um dos grupos que analisamos, o professor deixou um comando inicial, que era que um dos alunos ajudasse aos demais; o efeito desse comando sobre os alunos foi cristalizar essa dependência do professor no sentido de que não se podia deixar de cumprir aquilo que fora determinado. Por esse motivo o grupo não experimentou uma circulação dos papéis e a rede de comunicações foi marcada pela convergência para aquele aluno que o professor outorgara como o ajudante dos demais membros (SILVA \& VILLANI, 2006; ibid, 2007).

Contudo, a virtualidade do professor no grupo pode ter um efeito transitório, passageiro, que auxiliará o grupo na transição de uma fase para outra. E nesse sentido, o como se será também passageiro até que o próprio grupo perceba qual deve ser a melhor forma de operar e abordar a tarefa que o levará para autonomia e criatividade. A intervenção virtual funcionará como busca de uma solução no momento de tensão que é obtida através de uma figura transicional (PICHON-RIVIÈRE, 2005). A imagem do professor é aquela figura transicional na qual o grupo precisa se apoiar para se manter até que consiga prosseguir ruma à fase do projeto. 


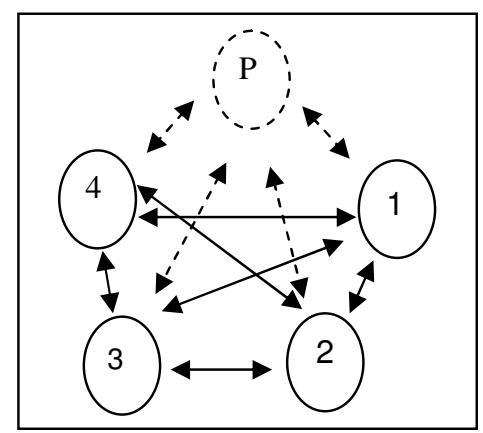

Fig. 11- Presença virtual do professor no grupo indicada pelas linhas tracejadas.

Poderíamos talvez, considerar a intervenção virtual como um caso particular da institucional, pois em ambas o professor não está presente. A característica essencial da primeira é a marca pessoal que o professor deixa no grupo da qual os alunos se apropriam na tentativa de se tornarem operativos. A intervenção institucional por si só, não garante isto.

É preciso deixar claro que as intervenções do professor são mais complexas do que estamos apresentando, pois os fatores apresentados presentes na ação docente ocorrem de forma simultânea, ou seja, quando o professor atua de forma institucional os alunos também lhe atribuem papel; quando está presente no grupo, mesmo ao assinalar ou interpretar, o professor pode intervir de forma institucional, pois é a forma em que ele aborda o tema que dá o seu aspecto normativo (Bleger, 2001). O que fizemos com essas categorias de intervenção foi tentar marcar alguns momentos e formas do professor manejar o grupo a fim de conduzi-lo para operatividade e autonomia, explicitando alguns aspectos nem sempre explorados na literatura corrente.

Assim, concluímos que o professor está constantemente presente no grupo; o efeito dessa presença pode ser, uma dependência em relação a ele ou uma superação dos obstáculos epistemológicos (tal como o definimos anteriormente) facilitando a abordagem da tarefa e da aprendizagem. Nesse esforço de promover essas categorias, buscamos resumir no quadro a seguir as principais características que podem assumir as intervenções docentes. 


\begin{tabular}{|c|c|c|}
\hline \multicolumn{2}{|c|}{ INTERVENÇÕES DO PROFESSOR NO GRUPO } \\
\hline INSTITCIONAL & PRESENCIAL & VIRTUAL \\
\hline $\begin{array}{c}\text { Enquadramento da } \\
\text { tarefa, estabelecimento } \\
\text { da tarefa }\end{array}$ & $\begin{array}{c}\text { Manutenção do enquadre e do } \\
\text { contrato }\end{array}$ & $\begin{array}{c}\text { Não é nem o enquadre nem } \\
\text { o contrato, mas uma } \\
\text { consequiência de ambos }\end{array}$ \\
$\begin{array}{c}\text { Refere-se ao aspecto } \\
\text { normativo }\end{array}$ & $\begin{array}{c}\text { Dá-se pela assinalação, } \\
\text { interpretação, múltiplas } \\
\text { transferências, favorecimento da } \\
\text { comunicação verbal e da } \\
\text { circulação dos papéis }\end{array}$ & $\begin{array}{c}\text { Atua como ruído, como o } \\
\text { terceiro que interfere na } \\
\text { comicação, mas que pode } \\
\text { servir como objeto } \\
\text { transicional }\end{array}$ \\
$\begin{array}{c}\text { Relaciona-se com a } \\
\text { tarefa explícita }\end{array}$ & $\begin{array}{c}\text { Relaciona-se com a tarefa } \\
\text { implícita }\end{array}$ & $\begin{array}{c}\text { Estabelece-se como se } \\
\text { operassem a tarefa explícita, } \\
\text { mas para elaborar a tarefa } \\
\text { implícita }\end{array}$ \\
\hline
\end{tabular}

Quadro 2-Principais características das intervenções do professor no grupo

"Se a canoa virar, foi por causa do (bode-expiatório) que não soube remar!" 
CAPÍTULO 4 


\section{4-ANÁLISE DAS AULAS DOS GRUPOS 3 E 1}

\section{1-Procedimentos da análise}

Após os comentários desenvolvidos sobre a metodologia que norteia nossa pesquisa, apresentamos, neste capítulo, o olhar analítico do pesquisador sobre a constituição do processo grupal das aulas de Física, com vistas para a comunicação entre os alunos, a sua relação com a tarefa e as intervenções do professor. Por conseguinte, conduziremos a análise amparados no respaldo teórico de Pichon-Rivière (2005), segundo o qual:

“(...) o instrumento de esclarecimento é dado pela interpretação enunciativa ou interrogativa- e o assinalamento, que têm sempre o caráter de uma hipótese sobre a fantasia grupal, não se avaliando sua eficácia segundo um critério de verdade, mas segundo o critério de operatividade, na medida em que permite a ruptura do estereótipo" (p.164, grifo nosso).

Esse procedimento foi descrito por esse autor para se referir à atuação do coordenador durante a técnica terapêutica do grupo operativo, do qual nos apropriamos da sua teoria para a condução da análise das aulas que apresentamos a seguir. É importante destacar que utilizamos os parâmetros teóricos na convergência de seus diversos instrumentos para a análise das aulas. Não se trata, portanto, de uma equiparação entre as duas funções, terapeuta e pesquisador, mas do uso da linha interpretativa com a finalidade acadêmica no sentido de compreender o processo grupal em uma aula de Física, a fim de que os professores possam fazer uso mais reflexivo das práticas de grupo enquanto recurso didático.

Sistematizamos processo interpretativo recortando as aulas e organizando-as em episódios, cujo critério foi a seleção de fatos que consideramos importantes para entender o que se passava nos grupos, caracterizando-se, portanto, uma interpretação de primeira ordem. Após esse recorte, enquanto processo analítico, criamos uma hipótese para cada grupo, e buscamos corroborá-la com os eventos ocorridos nos grupos. Em outras palavras, a partir do referencial adotado, atribuímos significados para as ações e palavras emitidas pelos grupos durantes as aulas de Física. É na atribuição de sentidos que consiste a interpretação de segunda ordem: 
"Produzir uma interpretação nos remete ao sentido mais originário que a constituição da palavra indica. 'Produção é levar para a adiante o revelado, o que se encontra retirado'. Nesse sentido, o produtor 'se presta entre' a matéria-prima e o produto como o espaço dessa transformação. Esse 'prestar-se entre' é o que o termo 'inter-pretar'. O intérprete produz um sentido a partir da matéria prima cuja natureza requer investigação" (FERNANDES, 1989, p. 75-76),

Basicamente, o que fizemos foi pensar em cada aula como uma:

“(...) sessão do grupo a desenvolver-se em três momentos temporais: abertura, desenvolvimento e fechamento. Os emergentes de abertura devem ser (...) registrados pelo observador (...) e observar como reaparece modificado no momento do fechamento" (PICHON-RIVIÈRE, 2005; p.181, grifo nosso).

Chamamos, então, de episódios os momentos temporais do desenvolvimento do grupo em cada aula, formados a partir de um conjunto de eventos, nos quais observamos: os momentos iniciais, o que os alunos diziam nessa situação, quanto tempo levavam para iniciar a atividade, como faziam as divisões das funções; as intervenções do professor e as do pesquisador, quando ocorriam e como o professor se comunicava com os alunos, quanto tempo permanecia com eles, qual frequiência de sua ida ao grupo e quais efeitos eram produzidos; e os momentos finais, em que verificamos como e se os alunos encerravam a sua atividade, qual era a telê do grupo nesse etapa, e se havia mudanças dos papéis dos alunos.

A constituição desses episódios ocorreu de duas formas: i) usando os gráficos com a indicação dos sistemas de comunicação; ii) descrevendo o que acontecia, com a inclusão da transcrição das falas, quando necessárias ou possíveis. Na primeira, cada gráfico representa um conjunto de eventos, marcando a temporalidade das ações dos alunos e a nossa interpretação está imersa na descrição das aulas. Enquanto que na outra, separamos a descrição, apontando os principais acontecimentos, iniciando cada episódio com um título que o representa, e após a parte descritiva, seguimos com a produção da interpretação.

Os gráficos foram usados, majoritariamente, para a análise do grupo 3; para o grupo 2, usamos a descrição sendo seguida da interpretação (de segunda ordem); e para o grupo 1, utilizamos os dois. 
Apresentamos a análise dos grupos na seqüência não hierárquica dos números que os classificam, ou seja, a apresentação seguirá desde o grupo da mudança ao da resistência, passando pelo da dependência. Outra forma de organização diz respeito ao número de aulas para cada grupo, duas para os grupos 3 e 1 e três para o grupo 2 . Por fim, este último nos chamou a atenção pelo seu processo de resistência, contrariando a nossa expectativa depositada sobre ele.

\section{2-O grupo da mudança}

O grupo da mudança é o grupo 3, composto por quatro membros (de nomes fictícios): Valentim, Ricardo, Tito e Hernam. Este último se integrou aos demais no segundo semestre daquele ano, pois Kevin mudou de escola. Escolhemos duas aulas para compor a análise, aula 8 , sem as funções e aula 13, com as funções.

Durante o primeiro semestre, a dinâmica grupal era fortemente controlada por um líder, Tito, que costumava tomar conta da tarefa: ele anotava os resultados, se questionava sobre eles e era quem chamava o professor quando havia dúvidas no grupo, mas também congregava o grupo e exortava os membros a realizarem a tarefa. Podemos dizer que havia nesse aluno um sentimento de pertença.

Os demais o faziam-no depositário dessa liderança, contudo Kevin tinha uma característica semelhante à de Tito, porém não tinha o mesmo reconhecimento dos colegas. Ele também costumava opinar na tarefa e demonstrava ter algum conhecimento do conteúdo dos exercícios e seria alguém que poderia competir pela liderança com Tito. Os outros dois alunos, Ricardo e Valentim, eram mais passivos dentro do grupo e demonstravam uma dependência da liderança. O primeiro era totalmente conformado com a situação, ao passo que Valentim costumava denunciar a liderança em certos momentos ou tentava exercê-la, sem muito sucesso.

As intervenções do professor durante o primeiro semestre foram ambíguas, no sentido de que algumas vezes reforçava a liderança de Tito: nos momentos em que era chamado a ir ao grupo, geralmente por Tito, ele mantinha um diálogo somente com este aluno. Parece-nos, que nesses casos, as intervenções não foram eficientes para fazer emergir as ansiedades e os medos básicos, bem como perturbar a rede de comunicação do grupo, proporcionando a circulação de papéis e a quebra da estereotipia. 
Entretanto, em outros momentos, quando o professor ia ao grupo sem que fosse chamado, conseguia abrir o diálogo com todo o grupo com suas intervenções, e não somente com Tito. Foi possível perceber que nessas intervenções Valentim e Ricardo pareciam participar mais. Geralmente, eles respondiam ao professor e gostavam de mostrar-lhe o que estavam fazendo nos exercícios. Esse fato possibilitou que os dois alunos começassem a se destacar mais durante as atividades.

A partir do momento em que as funções foram outorgadas aos alunos, acreditamos que o grupo foi colocado numa nova situação que permitiu ou até estimulou uma participação mais ativa de todos os membros: essa intervenção institucional promoveu a circulação do papel do líder. A conseqüência foi um salto qualitativo do grupo e uma vez que a liderança estava partilhada, eles não mais queriam voltar a situação anterior, criando assim uma nova rotina que de certo modo lhes era agradável.

Podemos dizer que o grupo experimentou um salto qualitativo em seu processo, iniciando um êxodo da pré-tarefa: a mudança teve como principal causa a inserção das funções, por ter ido ao encontro de anseio do grupo em assumir a liderança, sobretudo aqueles, apresentavam uma maior dependência em relação a Tito. Por exemplo, numa situação, cuja aula não fora filmada, observamos que Ricardo, após receber a função de Líder, abandonara a dependência em relação Tito e tinha a iniciativa de resolver da tarefa. Em uma outra aula, quando Valentim estava nessa mesma função perguntou várias vezes aos colegas era o Líder, só para ouvir deles a resposta de confirmação.

\subsection{1-Aula $8(12 / 08 / 2004)$}

Esta aula foi a primeira que registramos no segundo semestre letivo daquele ano, ou seja, logo após as férias de julho. O professor ainda não havia inserido as funções para o desenvolvimento da atividade, a qual nesta aula era um conjunto de exercícios do livro cujo conteúdo versava sobre Mecânica Newtoniana (identificação dos tipos de força, Leis de Newton e suas aplicações). Alguns desses exercícios foram pedidos para serem resolvidos durante as férias do meio de ano; porém, como a maior parte dos alunos nem tentara resolvê-los, o professor optou por uma revisão, pois a última aula do semestre anterior foi justamente sobre as Leis de Newton. 
A nossa hipótese sobre o grupo nesta aula é que os alunos se mantiveram na prétarefa, indicando que não houve uma circulação dos papéis devido à liderança exercida por Tito, que fora reforçada pelo professor, a quem era adjudicado pelo grupo o papel de líder também. Parece-nos que nesse grupo o papel de líder está associado ao domínio do conteúdo e só poderia exercer esse papel quem assim cumprisse este requisito.

Buscamos a partir daqui evidenciar alguns eventos que consideramos importantes para a compreensão do processo grupal desses alunos, pois o nosso esforço se concentrará na explicação das razões que levaram o grupo a permanecer nessa fase. A história do grupo 3 foi sintetizada em algumas etapas principais que indicamos na figura 12 abaixo.
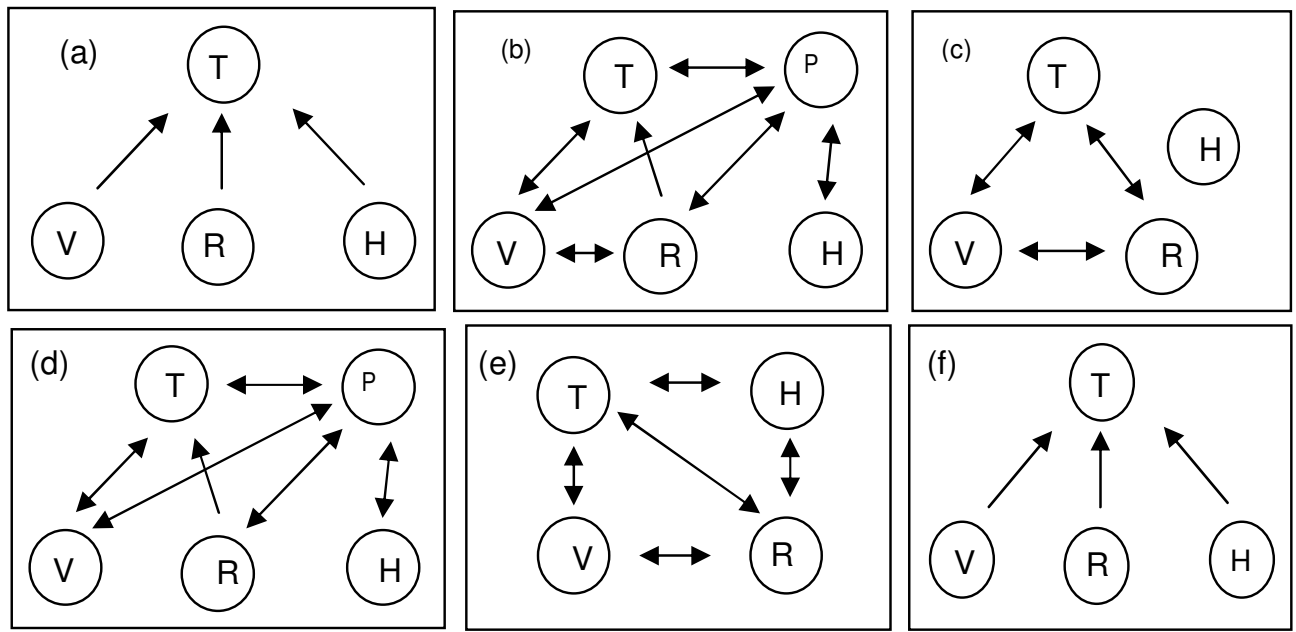

Fig. 12- Esquema indicando a história do grupo nesta aula.

No início, o professor (P) havia dado uma aula expositiva sobre o assunto em questão e o início da formação do grupo se deu logo após esta parte quando ele indicou a atividade que deveria ser resolvida, convocando toda a turma se reunir em grupos.

Prof.-Agora é com vocês! ...

Nesse meio tempo, porém, a turma não se mobilizou para a organização dos grupos, pois nos parece que os alunos não entenderam como sendo um pedido formal do professor. Desta maneira, foi preciso outra convocação para o início das atividades em grupo a qual identificamos como uma intervenção institucional, no sentido do estabelecimento de uma norma para os alunos:

Prof.- Então, sentem aí, comecem a fazer que daqui a pouco eu tô dando uma volta! 
Entre os grupos da turma, este foi o último a se formar e quem tomou a iniciativa de juntá-los foi Tito, reforçando o pedido do professor para os colegas. Ele assumiu nesse momento o papel de líder democrático do grupo, configurando um sistema de comunicação divergente, pois houve uma convocação de Tito para os colegas. Dissemos que se trata de uma liderança democrática devido como conduziu o grupo, diferente de Gomes, do grupo 2, em alguns momentos que cumpria esse papel de juntar o grupo.

Entendemos que Tito se tornou depositário daquela intervenção institucional do professor, reproduzindo-a no grupo e configurando-se um pacto (implícito) entre eles que ficará mais evidente a seguir quando o professor pede a Tito que ajude um colega. Entretanto, aquele sistema de comunicação logo sofreu uma mudança, pois o grupo lhe atribuiu o papel de líder progressivo, passando a funcionar um sistema convergente (Fig. 12-a).

Quando ocorreu essa mudança, os seus colegas se tornam depositantes cujo conteúdo era saber Física, ou seja, eles atribuíram o papel de líder a Tito por perceberem que poderia atuar como um "parceiro mais capaz" que os ajudaria a superar as dificuldades inerentes a esta disciplina. Como já apontamos, o líder do grupo era aquele que tivesse domínio do conteúdo. As falas a seguir nos mostram a convergência da comunicação para Tito:

Hernam - oh! Tito, não é assim? O sentido da força de atrito... assim...

Hernam - o próximo é assim, qual é o modulo, direção e sentido da força de atrito que age no bloco? (se refere a Tito)

Valentim - qual é este aqui? (mostra para Tito, perguntando o que significa o símbolo T usado no exercício)

Tito- É... tração eu acho!

Valentim - onde 'tão estas forças?

Tito - a força de tração, T. É bom ter isto anotado, vai... T, tração, entendeu... $N$, normal.

Valentim - $e$ P?

Tito- $P$ ? É... não sei (recorre ao livro)

Tito- $C$, contato, $N$ é normal, A é atrito... P?... P é peso, como que eu posso ter esquecido?!

Vemos que Hernam e Valentim depositaram a confiança na solução do exercício em Tito, que por sua vez aceitou essa transferência feita pelos seus colegas de grupo. É interessante observamos que "o papel adjudicado é o papel prescrito, ou o papel 
necessitado no grupo" (PICHON-RIVIÈRE, 2005, p. 145), ou seja, o papel de líder, que foi assumido por Tito, era o necessitado naquelas circunstâncias. Isso significa que "na medida em que os dois papéis coincidem- o prescrito e o assumido- produz-se o encaixe, a articulação" (ibid), fator importante para a fluidez da comunicação (sistema difuso) bem como para predominância dos vetores de cooperação e pertinência.

Essa relação com Tito se manifestava em outros momentos da aula, como o que destacamos a seguir: Hernam, que era novo no grupo, iniciou uma série de perguntas a Tito sobre sua forma de estudo e este revelou que resolvia todos os exercícios, inclusive durantes as férias.

Hernam- Tito, você estuda todo o dia?

Tito- Eu não preciso!

Hernam-Ah é!

Tito- Eu não preciso, só para a prova!

Hernam- Não, o cara tá a vinte exercício a frente de todo mundo e não faz!

Tito- Vai, isto foi o que o professor pediu nas férias

Hernam- Então você fez o que todo mundo não faz?

Hernam se tornara o porta-voz da demanda depositada em Tito, pois fazer o que "todo mundo não faz" significa maior destaque, ratificando o lugar deste aluno dentro do grupo. A partir daí, os outros alunos começaram vários questionamentos ao colega interessados em saber por que ele estudava daquele jeito.

Durante parte desse evento o professor estava presente no grupo, porém, não lhes dirigiu a palavra e observava o que os alunos discutiam, até que ele entrou na conversa para tentar desfazer a imagem que construíram de Tito, relativizando o conceito de estudar. Ao proceder assim, ele abriu canais de comunicação com o grupo, pois perguntava aos alunos e estes lhe correspondiam. A rede de comunicação sofreu alterações devido a presença do professor que aos poucos se configurava em 12-b.

Prof.- Sabe, o que acontece, às vezes a gente tem conceito diferente do outro do que é estudar. Então por exemplo, ele fala assim: ah estudei. O que é estudar para você?

Tito- Pra mim? Pra mim estudar é pegar no caderno resolver exercício, entender...

Prof.- Entender é a conseqüência!

Tito- É ... porque eu preciso entender...

Prof.- Você não faz os exercícios que eu ponho na lousa para serem feitos em casa? 
Tito- Ah! Eu faço! Nem todos, mas eu faço!

Prof.- Então você estuda!... Então, a gente tá vendo assim, que estudar para você seria fazer todos os exercícios, cem por cento?

Tito - Ah! É professor.

Prof.- Estudar... é pegar e fazer exercício. Lógico, de repente, talvez. não tenha tempo para fazer todos e acaba não fazendo, de repente, não sei?

Tito - Os dois!

Prof.- Os dois, mas não pode dizer que não estudou. De repente você pode falar que estuda ...ou que você gostaria de estudar mais.

Valentim- Professor, eu comecei agora!

Prof.- Agora que você começou a estudar! E em casa?

Valentim - Então!?

Prof.- Então, o Valentim está estudando! ... Na medida em que vocês forem fazendo isto, vocês vão percebendo que... as coisas vão ficando mais fáceis e na medida em que fica mais fácil, é... parece que a gente tira um peso das costas (...).

O professor atuou junto ao grupo no sentido de uma intervenção presencial quando tentava indicar aos alunos que forma que Tito estudava não era a única. Em outras palavras, podemos considerar que quando o professor dizia, "às vezes a gente tem conceito diferente do que é estudar", sinalizava aos estudantes que o lugar dado a Tito no grupo não era exclusividade dele. Se o grupo aceitasse essa mensagem do professor, passaria "a funcionar sobre implícitos compartilhados, que se refletem nas características que tomam os papéis, que, de fixos estereotipados, se tornam funcionais" e complementares entre si (PICHON-RIVIÈRE, 2005, p.145). No caso deste grupo, era o papel de líder que deveria deixar de ser fixo e tornar-se funcional, para que o grupo experimentasse a saída da pré-tarefa.

Em seguida, o professor começou a conversar com Hernam, perguntando-lhe sobre as aulas de Física na outra escola e se ele gostava ou não desta disciplina. Essa atenção a este aluno pode ser entendida como uma forma de incluí-lo no grupo, já que era primeira aula junto com os outros alunos para resolver a atividade. Contudo, esse diálogo não se prolongou muito e com isso encerrava sua intervenção no grupo, e antes de sair ele reforçou a liderança de Tito ao dizer:

Prof.- Só tô com um receio aqui, se Tito já fez tudo...

Valentim- Professor, eu tô fazendo, professor! (interrompendo-o)

Prof.- ... e vocês não ... é vocês três parecem que estão mais ou menos no mesmo lugar,no mesmo problema.

Hernam-Só o Tito que é... 
Prof- Dá uma mão para eles (fala para Tito), mas não a reposta. Isso que eu peço... dá uma ajuda, mas assim, não seja muito Papai Noel. Qualquer coisa me chamem!

Se antes o professor tentava desfazer a imagem de liderança inatingível de Tito, agora, com esse pedido, ele validou o papel de líder (inatingível) deste aluno e estabeleceu uma nova forma do grupo agir, que era sob os cuidados de Tito. Este, mais uma vez, se tornara depositário dessa intervenção institucional- porque criou outra norma para os alunos- confirmando aquele pacto do início da aula entre o professor e Tito. A essa última fala do professor, ainda podemos atribuir o seguinte significado: "Como você é o único a fazer o que todo mundo não faz, você tem a capacidade de dar uma mão para eles!".

É importante percebermos que quando o professor dizia que somente Tito era que tinha feito tudo, Valentim logo se manifestou para mostrar-lhe que também estava fazendo. Ora, nesse contexto essa fala é muito significativa, porque fazer o exercício era o sinal da liderança no grupo ("fazer tudo o todo mundo não faz"). Logo, Valentim assumiu o papel de porta-voz dessa ansiedade do grupo para ocupar o lugar de Tito. Ressaltamos que em uma outra aula, esse mesmo aluno havia recebido a função de Líder e por isso perguntava um a um no grupo quem era o Líder, só para ouvir dos colegas que era ele quem ocupava essa função, para ele estar nessa posição significava atingir o inatingível.

Por outro lado, Tito aceitou a transferência dos outros alunos sobre si, quando os seus eles o colocavam como líder. O trecho a seguir nos indica isto:

Hernam - oh! T, não é assim? O sentido da força de atrito... assim...

Hernam - o próximo é assim, qual é o modulo, direção e sentido da força de atrito que age no bloco? (se refere a $T$ )

Valentim - qual é este T, aqui? (mostra ao aluno T, perguntando o que significa o símbolo T usado no exercício)

Tito- É... tração eu acho!

Valentim - onde estão estas forças?

Tito- a força de tração, T. É bom ter isto anotado, vai... T, tração, entendeu... $N$, normal.

Valentim - $e$ P?

Tito- $P$ ? É... não sei (recorre ao livro) $C$, contato, $N$ é normal, $A$ é atrito... P?... P é peso, como que pude eu ter esquecido?! 
Tito assumia uma liderança democrática e se preocupava em cumprir aquela demanda do professor de ajudar os colegas de tal forma que se culpava por esquecer ou não saber algo que lhe perguntassem, como ele indica ao dizer "como eu pude ter esquecido". Esquecer ou não saber lhe tiraria do lugar de líder e representaria um não cumprimento do pacto que fora estabelecido entre ele e o professor, motivo aparente de sentir-se culpado.

Logo após a saída do professor, grupo se fechou entre Tito, Valentim e Ricardo, iniciando um processo de exclusão de Hernam. Ele tentou falar com Tito, mas este não lhe respondeu porque estava ajudando Valentim, então Hernam chamou Ricardo. A configuração da Fig. 12-c nos indica o episódio da exclusão de Hernam no grupo

Hernam- Ô Ricardo, o que você colocou na oito?

Ricardo- Oito?

Hernam- A oito!

Ricardo- Pera aí, pera aí! Só fazer o exercício aqui rapidinho!

Como não obteve respostas do colega, ele seguiu lendo o livro para achar uma solução para o seu problema. Em seguida, ele solicitou o pesquisador para ajudá-lo com sua dúvida, promovendo uma interação entre os dois, pois os demais membros do grupo estavam envolvidos com outro exercício.

A exclusão de Hernam tornou-se explícita quando ele fora hostilizado por Valentim e Ricardo:

Hernam- quais são as forças que agem aqui?

Tito - a força que puxa para a Terra...

Hernam - gravidade?!?...peso, né?

Tito- (concorda com ele)... eu não sei se você pegou a aula quando você tava aqui? ... lá onde você estudava, você aprendeu todos os tipos de força?... tração...

Hernam - eu não aprendi este negócio lá, eu não aprendi gravidade ainda não!

Tito- (começa a explicar para $H$ )

Valentim - faz âe, mano!

Ricardo - fugiu da raia agora?

(...)

Tito - o cara chegou agora na escola!

Ricardo - maior, cdf atrasado!!

Valentim - ô cdf atrasado! 
Nesse evento, Valentim iniciou o ataque ao Hernam, sendo acompanho por Ricardo. É significativa a forma como ele iniciou a empreitada contra o colega, dizendo "faz aê!", ironicamente, pois fazer significava para os alunos ocupar o lugar da liderança. Valentim tentou fazer (“professor, eu to fazendo!”) e não obteve sucesso, outro aluno não poderia então fazer, muito menos Hernam que "chegou agora na escola".

Quando recorremos ao nosso referencial teórico, é possível apontarmos outros motivos pelo quais esses dois alunos rechaçaram o colega. Segundo Pichon-Rivière (2005), o papel do bode-expiatório surge quando um membro do grupo torna-se depositário das ansiedades e dos aspectos negativos do grupo ou da tarefa, cuja conseqüência é o mecanismo de segregação. Por outro lado, quando um membro se torna o depositário dos aspectos positivos do grupo lhe conferem o papel de líder. Porém, ambos os papéis surgem como preservação da liderança, "através de um processo de dissociação (...), necessário ao grupo em sua tarefa de discriminação" (p. 180). No caso desse episódio, Valentim e Ricardo queriam assegurar a liderança de Tito, conferida a ele pelo professor, pois se outro assumisse este papel não teriam garantias de que o novo líder os ajudaria nos exercícios. Além disso, apontamos que:

- o movimento desses dois alunos de atacarem Hernam surgiu quando este, ao tentar fazer o exercício, pediu ajuda a Tito, sendo por isso desafiado, com as palavras: "faz aê!" e "fugiu da raia agora";

- Valentim e Ricardo operavam sob as ansiedades básicas de medo e ataque, pois Tito representava para eles uma segurança no fazer da tarefa, enquanto Hernam representava a ameaça que poderia afastar Tito deles.

Inferimos desse episódio que o grupo estava preso àquela intervenção institucional do professor em que fora solicitado a Tito cuidar dos colegas. Então, o rechaço de Hernam pode significar uma resistência à mudança que era a circulação da liderança. Logo, segundo essa nossa interpretação, aqueles dois alunos assumiram o papel de sabotadores do grupo, atuando como lideres da resistência.

Após alguns minutos, o professor retornou ao grupo, mas a sua intervenção não gera imediatamente a configuração 12-d. Inicialmente quem abriu um canal de comunicação foi Tito. Ele tinha uma dúvida sobre um exercício que somente ele 
resolvia porque os demais estavam defasados em relação a ele. E os dois mantiveram um diálogo sobre o exercício.

Mesmo Tito estando incumbido de "dar uma mão" ao grupo e estando adiantado nos exercícios, ele se manteve resolvendo outros exercícios, bem diferentes dos seus colegas. Isso pode significar que havia uma satisfação de Tito em permanecer no lugar que lhe colocaram no grupo (o professor e os outros alunos) e para mantê-lo era preciso sempre estar inatingível. Conversar com o professor individualmente, também pode ter esse sentido de manutenção do seu status no grupo e bem como do pacto com o professor.

Contudo, a presença do professor, aos poucos, foi promovendo abertura de canais de comunicação entre os alunos e entre estes e o professor, gerando no grupo (alunos e professor) um sistema de comunicação praticamente difuso (12-d). Essa intervenção, presencial, foi importante porque o professor atuava, enquanto membro do grupo nesse momento, como líder progressivo facilitando a comunicação, permitindo as transferências que os alunos lhe faziam e ajudando superação da segregação em que Hernam fora rechaçado por seus colegas. Nos momentos em que intervinha, os alunos podiam "soltar a mão" de Tito, porque era o professor mesmo quem os "conduzia".

Além disso, quando ele estava presente no grupo, havia uma chance maior de que alguém fosse colocado como líder, tal como o fora Tito, mas era preciso cumprir a regra que se estabelecera entre eles de fazer o exercício e apresentar domínio do conteúdo. Não por acaso, quando o professor terminou de explicar a Tito, Ricardo entrou em cena para também mostrar-lhe o que ele havia feito, sendo acompanhado por Valentim.

A intervenção presencial do professor neste caso conseguiu favorecer a participação de todos, oferecendo em seguida um sistema de comunicação nem tão estereotipado pela convergência em Tito. O grupo, na configuração 12-e, parecia que operava segundo complementaridade dos papéis, incluindo a circulação da liderança, pois, quase ao término da aula, os alunos já haviam feito mais exercícios em relação ao início da atividade.

Os canais de comunicação que foram abertos enquanto o professor permanecia no grupo não foram duradouros, ou em outras palavras, a comunicação convergiu para um membro somente: Tito. O motivo foi uma dificuldade que encontrada no exercício, 
a qual não conseguiram suportar a ansiedade diante de uma nova situação e todos recorreram a Tito, gerando a configuração 12-f.

A nova situação encontrada era "soltar a mão" de Tito e o grupo enquanto totalidade entrar no processo de pensamento sobre a atividade e cada qual contribuir para a solução, operando segundo a complementaridade dos papéis. A realização dessa trajetória, faria com que o grupo vivesse um posição esquizoparanóide: os alunos não teriam nem árvore nem canoa, ou seja, eles não teriam a mão de Tito e nem teriam outro para colocar no lugar dele. Parece-nos então, que a tarefa implícita do grupo consistia na elaboração dessa dependência em relação a Tito perceber que alguém mais poderia atingir o inatingível. Como conseqüência, o grupo não experimentou um salto qualitativo, com sucessivos momentos de sínteses, que implicariam num processo dialético.

Uma ampliação de nossa interpretação pode ser encontrada em Pichon-Rivière (2005) quando ele diz sobre a “inevitável presença, no campo da aprendizagem, do obstáculo epistemológico" (p 12, grifo nosso). Para ele, ocorre uma fragmentação do objeto de conhecimento formando domínios particulares (do conhecimento), conseqüência da fragmentação do vínculo. O episódio mais evidente disso ocorreu com Hernam ao lhe atribuírem o papel de bode-expiatório para preservarem a liderança de Tito. O grupo vivenciou o que ele nomeia de momentos dipolares. Entretanto, se cada fragmentação for seguida por um momento integrador, "cumprindo assim dois processos de sinais contrários, que adquirem complementaridade através da experiência emocional corretora" vai gerar uma epistemologia convergente (ibid, p. 12).

Esse obstáculo provoca um ruído na comunicação dos sujeitos e transforma a espiral dialética da aprendizagem em círculo fechado e o que está em jogo nesse momento é o vínculo que "deve ser definido como mecanismo de interação que é ao mesmo tempo bicorporal e tripessoal" (ibid, p.11). Com isso o autor salienta simultaneamente a importância da presença física dos sujeitos que se mantém em comunicação e a perturbação desta comunicação por suas relações com um Outro ao qual prestam conta:

"O perturbador de todo o contexto de conhecimento é o terceiro, cuja presença em nível do vínculo e do diálogo condiciona os mais graves distúrbios da comunicação e da aprendizagem" (ibid.). 
Em nosso caso essa perturbação está associada à figura do professor, que sem estar presente no grupo interfere na forma de ruído na comunicação entre os alunos, ou seja, aquele pedido inicial a Tito permaneceu como um ruído impedindo os alunos de passarem por momentos de integração que seria soltar da mão de Tito.

O que concluímos é que nesta aula o grupo abriu e fechou a atividade com uma comunicação convergente, o que não seria um problema se não fosse o fato de que foi para o mesmo aluno. Isso é típico de um grupo na pré-tarefa, indicando uma resistência à mudança e uma estereotipia do papel de líder, sempre assumido por Tito ou pelo professor.

As intervenções do professor tinham, de um modo geral, algumas características que ora favoreciam a circulação dos papéis ora reforçavam a liderança de Tito. Nas figuras 12-b e 12-d há uma representação do professor conseguindo minimizar o efeito da estereotipia e do aspecto normativo de suas intervenções institucionais, pois os gráficos seguintes, respectivamente, não nos mostram a convergência para T. Enquanto o professor estava presente no grupo, Ricardo e Valentim mostravam-se interessados pela atividade, pois sempre apresentavam seus cadernos com os exercícios feitos. Esse é um fato significativo, porque fazer significava exercer a liderança. Logo, podemos considerar que há nesse evento uma indicação que eles almejavam pelo papel de líder.

Em resumo, o grupo não experimentou uma epistemologia convergente, visto que:

- A Tito foi atribuído um lugar de inatingível entre os alunos grupo, pois ele "fez o que todo mundo não faz" e por conta disso, o professor pediu que ele ajudasse o grupo;

- Os alunos atribuíam a ele e ao professor o papel de líder, como detentores do saber Física, impedindo que as situações dilemáticas pudessem ser resolvidas a partir do diálogo entre todos;

- A ambigüidade nas intervenções do professor, que ora outorgava a Tito a liderança, ora ele assumia esse papel;

- A intervenção institucional do professor no começo da aula representou para os alunos um caráter normativo definindo a forma de tratar a tarefa (BLEGER, 2001): a sua realização deveria ser feita através da liderança de Tito. Essa intervenção funcionou como ruído na comunicação dos alunos. 


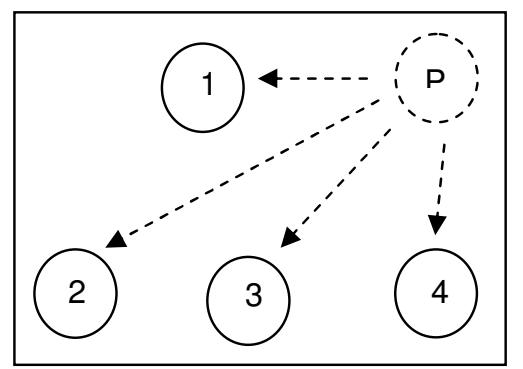

Fig. 13- Esquema indicando a intervenção virtual do professor que se manteve durante esta aula.

\subsection{2-Aula $13(23 / 09 / 2004)$}

Nesta aula o grupo estava sob a organização das funções e os próprios alunos decidiam entre si quem assumiria qual delas, e a seguinte configuração se estabelecera: Hernam, Líder; Tito Anotador; Valentim e Ricardo questionadores. Nas outras aulas, nas quais este grupo não fora filmado, esse ritual de divisão também era seguido.

A atividade era composta por um conjunto de exercícios que o professor escreveu na lousa, diferenciando-os daqueles do livro texto cujo conteúdo versava sobre energia e trabalho, com a ênfase em energias cinética, potencial gravitacional e potencial elástica. O seu início se coincidiu com o início da aula, pois os alunos teriam a sua prova bimestral de Física naquele mesmo dia, diferenciando da aula 8 quando o professor primeiro fez uma exposição do conteúdo e depois pediu que se formassem os grupos.

O que admitimos como hipótese inicial é que o grupo na aula 13 experimentou uma mudança em sua dinâmica devida uma maior circulação dos papéis assumidos pelos alunos, indicando uma entrada na fase da tarefa, ou pelo menos uma saída de pré-tarefa As funções atuaram como catalisadoras desse processo de mudança ao favorecer que a liderança fosse partilhada por diferentes membros, sem, no entanto, $o$ abandono daquela concepção de que ser líder é saber Física. Essa forma de perceber o líder foi causa de disputas por esse lugar dentro do grupo entre Tito e Hernam.

Tal como fizemos com a aula analisada anteriormente, sintetizamos a história do grupo através dos esquemas, em sequiência cronológica de eventos que consideramos mais significativos, que nos indicam a configuração dos alunos a partir da comunicação verbal gerada entre eles, numa tentativa de explicar por que o grupo atingiu aquela fase. 

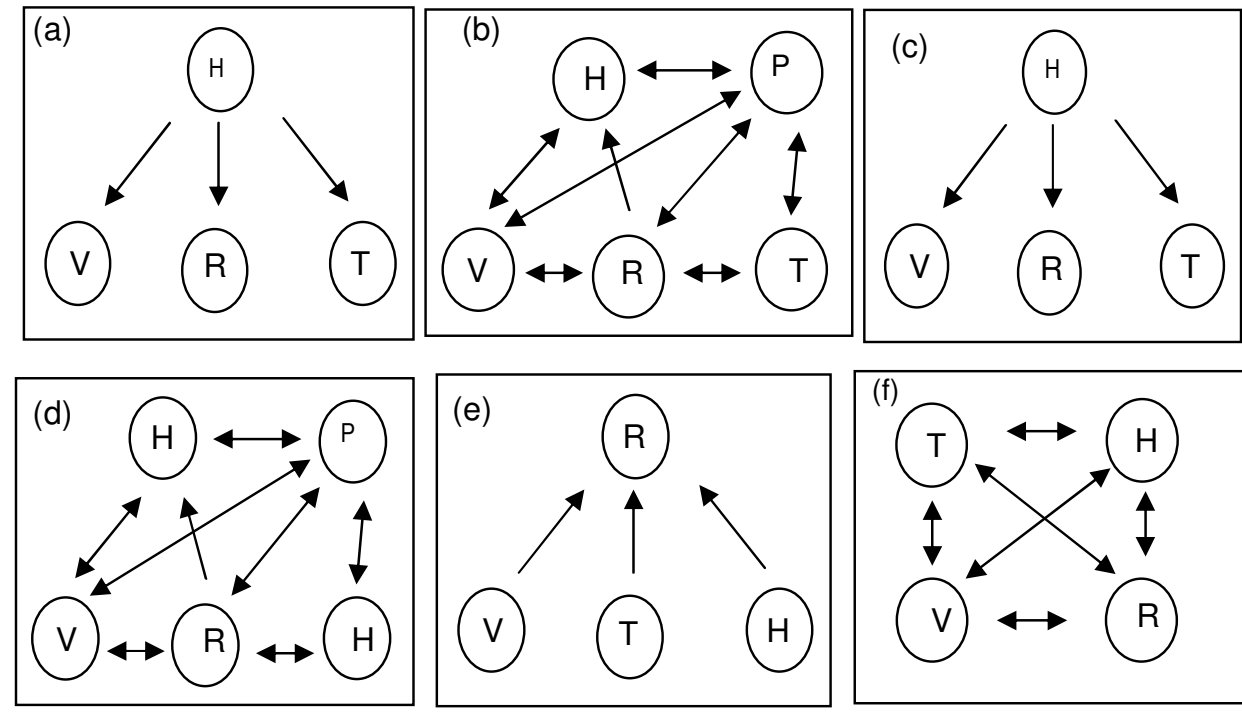

Fig. 14- Esquema indicando a evolução do grupo nesta aula.

Como já indicamos, Hernam estava na função de Líder e ele a exerceu assumindo o papel de líder autocrático, ao agir de forma autoritária, gerando assim um sistema de comunicação divergente no grupo (figura 14-a). Afirmamos isso, pois quando o professor pediu que se iniciassem as atividades, esse aluno deu um comando inicial para os colegas de como deveriam resolver o exercício:

\section{Hernam- Pergunta aí! Qual é a pergunta?}

Tito- Tá na lousa, lê!

Ninguém o respondeu a não ser Tito, que parecia resistir à liderança de Hernam, ou à sua forma de exercê-la. Em seguida, como todos permaneceram em silêncio, Tito se manifestou aos colegas numa tentativa de iniciar o exercício, propondo uma possível solução e pedindo uma confirmação do grupo, mas não obteve sucesso. Logo depois, Hernam deu o seu novo comando.

\section{Hernam- Vamos ler o capítulo primeiro! ... Todo mundo lendo o capítulo aí!}

Tito- Já li!

Ao dizer "já li", Tito afirmava que ele estava autorizado exercer a liderança, pois sabia do que se tratava o tema do exercício: era o início da disputa entre Tito e Hernam pelo lugar de líder dentro do grupo. Com esse evento notamos um dos efeitos das funções neste grupo que foi promover a circulação do papel líder entre os membros do grupo, pois na aula anterior, Tito fora autorizado pelo o professor a atuar como nesse papel, pois ele sabia Física. 
Quando comparamos as duas aulas, percebemos uma diferença que nos parece importante para compreender a dinâmica deste grupo: Tito não estava no lugar do líder como na aula 8, pois lá o professor o indicara para tal ao pedir que ele "desse uma mão" aos seus colegas. Na aula 13, era Hernam quem ocupava aquele lugar do líder, devido à função que lhe fora atribuída, implicando assim uma nova situação em que o grupo se encontrava.

Uma nova situação significa que o grupo experimentava outra configuração, na qual "o sujeito vê-se impotente no manejo de seu novo papel, e isso cria um baixo limite de tolerância às frustrações, em relação às suas aspirações" (PICHON-RIVIĖRE, 2005, p. 14). Consideramos que manejar um novo papel, seja a causa da postura de intolerância de Tito para com Hernam, cujas falas do primeiro- "Tá na lousa, lê!” e "Já li!’-nos permitem essa interpretação, e que para complementá-la, recorremos à analogia da árvore e da canoa: era como se Tito não tivesse a árvore e nem ainda havia construído a canoa. Por conseguinte, trata-se de um posição esquizoparanóide que ele vivenciava, pela perda do lugar do líder.

Na seqüência, Ricardo tentou tomar alguma iniciativa para resolver a primeira questão, mas foi interrompido por Tito:

\section{Ricardo- Quais as características (...)}

Tito- Siga o líder! (interrompe R falando ironicamente)

Ricardo- Beleza! (ao falar isto, para de ler o exercício da lousa e pega o seu livro para ler o capítulo)

Nesse evento há dois fatos importantes: Ricardo ter chamado o grupo para iniciar a atividade nos revela que o grupo vivenciava uma configuração nova, diferente da aula 8, porque não é típico desse aluno atitudes como a que ele teve ao tentar iniciar a resolução do exercício. Ricardo, também almejava o lugar do líder do grupo, uma vez que este parecia não mais pertencer a um único aluno.

O outro fato consiste na resposta de Tito ao colega que, por um lado corrobora com o que dissemos anteriormente, pois "seguir o líder" pode significar que ele estivesse se auto-proclamando como tal, obtendo, inclusive, a obediência de Ricardo. Por outro lado, a fala de Tito indica a importância atribuída ao papel de líder, tornandose porta-voz ao explicitar essa latência do grupo.

Parece-nos, esse, um bom exemplo de como surge o porta-voz, aquele que enuncia suas necessidades, ansiedades e fantasias inconscientes cuja forma de fazê-las 
se refere a sua história pessoal (aspecto vertical do emergente), enquanto que o fato de formulá-las num dado momento do acontecer grupal, no qual está inserido, assinala o caráter horizontal do que está emergindo (PICHON-RIVIÈRE, 2005). A forma irônica de Tito expressar-se com Ricardo diz respeito a sua intolerância com a nova situação (verticalidade de Tito) e o fato de dizê-lo enuncia o que se passava na totalidade do grupo, em relação ao papel de líder (horizontalidade do grupo). Nas palavras de Pichon-Rivière:

"Esse encaixe permite a emergência do material que deve ser interpretado. A interpretação utilizará esses dois elementos: o vertical e o horizontal. Através do problema enunciado pelo porta-voz em sua verticalidade, deve-se exemplificar a situação de todos os membros do grupo, no aqui e no agora, e em relação com a tarefa" (2005, p. 180).

Afinal, qual líder Ricardo deveria seguir? Ele deveria seguir quem estivesse no lugar do líder, o que significa que era quem o grupo legitimasse para ocupar tal lugar, cuja condição era saber Física. Percebemos com esse episódio que Tito buscava esse reconhecimento.

Mesmo Hernam assumindo o papel de líder autocrático, Tito era ainda reconhecido pelo grupo como um líder também, porque ele sabia Física e tão logo encontravam uma dificuldade o grupo recorria ao colega para que os ajudasse, formando-se, nesses momentos, um sistema convergente na comunicação dos alunos. Porém, ao contrário da aula anterior, Tito não aceitava tão facilmente torna-se depositário da liderança, mostrando-se resistente aos pedidos de ajuda de alguns deles, ainda que ele aspirasse pelo lugar do líder. Vejamos:

Hernam- Tito, não tô entendendo aqui!

Ricardo-Você é o líder, você tem que entender!

Hernam- Então, eu entendo aqui o que é fácil! ... Então Tito, explica aí pra gente!

Valentim- a fórmula da energia cinética é ' $m v$ ao quadrado dividido por dois (fala para Tito)

Tito- $O$ que é ' $m v$ '?

Valentim - massa ... massa e velocidade (...) Errei?!

Tito- Será?!

(...)

Tito - Tá certo? Tá certo o que você está falando? Leia! 
Depois de alguns instantes Ricardo se manifestou:

Ricardo- Tá certo! Olha aqui, ó! (mostra o livro) Unidades de massa e velocidade...

Valentim - Muito obrigado, gente! Um pontinho para mim!

Parece-nos que Tito não respondia tão prontamente a Hernam, mas aos outros colegas sim, como percebemos com Valentim e Ricardo. Além disso, a fala de Ricardo para Hernam é importante, pois explicita qual a condição para ser líder: saber e entender tudo. Era como se ele estivesse desautorizando Hernam a ocupar aquele posto e formando com Tito um subgrupo, que tinha este aluno como líder, já que ele sabia Física. Logo, o líder a que Ricardo deveria seguir era Tito.

Na seqüência, todos então liam o capítulo, como Hernam havia solicitado no início, até que surgiu um novo diálogo no grupo: Hernam tentava dar a sua explicação sobre a energia cinética baseando-se no que havia lido no livro, gerando uma tensão entre os alunos e tornando-se mais evidente a disputa entre Tito e Hernam pela liderança.

Hernam- Acho que é assim, ó (olha para Tito), energia cinética... energia cinética (não consegue concluir, mas espera a ajuda de Tito)

Ricardo- A energia cinética (fala para Tito), você identifica ela quando você vê que o corpo está em movimento.

Hernam - É, é isto aí mesmo. O que está escrito aqui é: a energia cinética...

Tito - (lê junto com Hernam, interrompendo-o)

Hernam - Dá licença! (fala para Tito) Dá licença! ... Dá licença! (ele fala enquanto Tito estava lendo)

Algo aconteceu no grupo ${ }^{17}$ fazendo Tito interromper sua leitura, abrindo o espaço para Hernam prosseguir:

Hernam - Deixa eu explicar para vocês... a energia cinética ... (continua lendo o livro).

Quando Hernam terminou de ler para o grupo, Ricardo releu para confirmar, seguido de Tito que também o fez e por fim, primeiro leu mais uma vez e indicou que estava encerrada aquela discussão. O mais distante desse processo foi Valentim que pouco participou. Em seguida, o grupo relaxou após esse momento de tensão. Passados

\footnotetext{
${ }^{17}$ Durante a leitura de $\mathrm{H}$ e T, parece que alguém esbarrou no microfone que estava entre as carteiras dos alunos, então $\mathrm{T}$ fica um pouco preocupado e pede cuidado aos demais, e nesse ínterim que $\mathrm{H}$ completa sua leitura.
} 
alguns instantes, Ricardo ofereceu ao grupo uma última síntese dando como possível responder a questão inicial:

Ricardo - Já dá para saber (se referindo ao exercício que ele tinha dúvida)... energia cinética é também quando o corpo está em movimento ... (se direciona para Hernam e depois para Tito. Estes são os dois pólos de oscilação da liderança).

Com esses acontecimentos no grupo, é possível perceber que a assunção ou adjudicação do papel do líder aparecia de duas formas: através da função de Líder e do domínio do conteúdo de Física. Notamos no início da atividade como Hernam se apropriou da sua função e como os demais o viam: podemos dizer que havia um respeito por ele, cuja comprovação se dava quando todos liam o capítulo, inclusive Tito. Essa postura do grupo de "ler o capítulo" se repetiu por várias vezes durante essa atividade.

Por outro lado, o grupo esperava do Líder repostas certas para fazer com que eles saíssem de uma situação dilemática, isto foi explicitado quando Ricardo falou que o Líder deveria entender tudo. Assim, entendemos que essa é uma das razões pela qual ocorria a disputa pelo lugar do líder entre Hernam e Tito: o primeiro era o Líder devido à função que lhe foi dada e o outro por causa do domínio do conteúdo. A tensão aumentava quando Hernam indicava que ele também sabia Física, como observamos no ultimo diálogo ao dizer: "deixa eu explicar para vocês".

Por fim, sobre esse episódio, concluímos que entre os gráficos da Fig. 14-a e 14b, houve uma oscilação dos sistemas de comunicação convergente e divergente, devido àquela disputa pela liderança. Identificamos aí uma situação estereotipada na qual o papel do líder estava sempre entre aqueles dois alunos. Entretanto, apontamos como um sistema divergente possível quando Ricardo trouxe ao grupo a síntese daquele momento de tensão.

Dizemos então, que esse aluno assumiu o papel de porta-voz da ansiedade dos alunos devida àquela situação dilemática gerada pela incerteza sobre a energia cinética, a qual estava diretamente associada à resposta do problema. O grupo percebia que havia uma possibilidade de não conseguir encontrar a solução do problema, cuja causa estava naquela disputa. Na medida em que se reconhecia essa "denúncia" de Ricardo, ele passava a atuar o líder progressivo. 
O que vemos é que naquela disputa abria-se a possibilidade para que outros assumissem o papel de líder, como foi o caso de Ricardo, em sua última fala, quando ele sacramentou a discussão, indicando que era possível resolverem o exercício, porque ele também sabia (“Já da pra saber”) do que se tratava a energia cinética.

Ao nosso parecer, a grande novidade que as funções introduziram no grupo foi o fato de que outros poderiam ocupar o lugar do líder. Contudo, faltava-lhes ainda um processo de elaboração desse desejo pela liderança, que passou a ser a tarefa implícita do grupo.
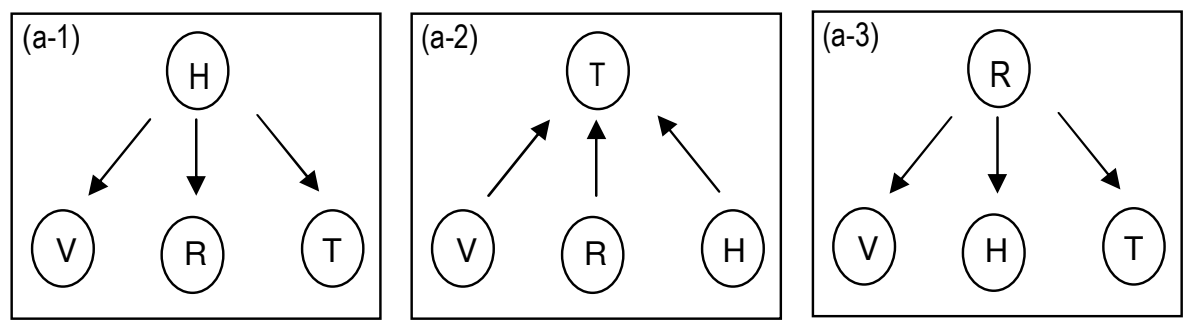

Fig. 15- Esquema mostrando a mudança de papéis entre, H, T e R.

Quando o professor chegou ao grupo encontrou a configuração da Fig. 15-a3, em que Ricardo acabara de assumir o papel de líder progressivo, e foi ele quem abriu um primeiro canal de comunicação com o professor. Estabeleceu-se um diálogo entre os dois, que logo em seguida fora acompanhado por Hernam, e aos poucos era gerada a configuração 14-b, indicando que a rede de comunicação no grupo se reajustava, ao menos enquanto o professor estava no grupo. Vejamos como se estabeleceu este diálogo

Ricardo- A energia cinética é também quando o corpo tem, ..., heim ó (chama Tito)... a energia cinética é também quando o corpo tem .. a não! Calma aí!... esquece.... (aqui ele já se refere a energia potencial gravitacional que está no exercício seguinte)

Ricardo - Energia... potência, ... energia potencial gravitacional ...(momento em que o professor chega no grupo, então ele deixa de falar com Te se volta para o professor)

Ricardo - Energia potencial é quando você olha para o corpo e você vê que ele tem um potencial para se movimentar? ... ou aí tem outro sentido?

Prof.- Quando um corpo tem um potencial para se movimentar é porque ele tem algum tipo de energia, qual tipo energia eu não sei ...

Hernam-energia armazenada ... (lê rapidamente no livro) pode ser transformada em cinética.

Prof.- O que acha...que chama de energia armazenada ... é ... tem energia...

Hernam- Potencial! É isso?! 
Prof. Qual?

Hernam-Potencial!

Prof. É!

Hernam- Ela tá armazenada e pode ser transformada em energia cinética...

Ricardo - ... cinética (fala quase junto com Hernam)

Prof.- Daí pode ser potencial ... ou gravitacional ou elástica, depende de onde ele tá...

Consideramos como sendo uma intervenção presencial atuação do professor no grupo, porque toda a rede de comunicação entre os alunos foi reajustada de maneira que os canais de comunicação não eram abertos somente para o professor, mas também entre os membros do grupo (Fig. 14-c), como nos indica a fala de Hernam para Tito, advertindo-o sobre um resultado:

Hernam- Cuidado! Você acha que certo aí?

A presença do professor foi muito significativa, visto que ele ajudou os alunos a encontrar aqueles momentos integradores do objeto de conhecimento, segundo PichonRivière (2005). A integração ocorreu, justamente, naquele ponto dilemático em relação à energia cinética que acontecia antes da chegada do professor e que de certa forma estava resolvido. Vejamos como ele o fez:

Prof.- Não esqueçam os Questionadores... tem que trabalhar! São os Questionadores que vão fazer o grupo ficar com a pulga atrás da orelha, para ver se realmente entendem ou não...

Prof.- Por exemplo, o que vocês fizeram agora...

Tito- Energia Cinética, por exemplo, energia associada a corpos que estão em movimento (lê o livro).

(...)

Prof.- Aí tem alguma dúvida nisto aí?

Ricardo - Ah! Isto é fácil!

Prof.- Qualquer corpo em movimento tem energia cinética ... (confirma a informação)

Para explicar-lhes o conteúdo, o professor iniciou com uma intervenção institucional quando fez uma cobrança da função de Questionador, e como no grupo 1, ele assumiu esta função para indicar aos alunos como eles deveriam proceder. Após aquela conclusão que o professor ofereceu, ainda em sua presença, os alunos mantiveram-se em silêncio numa postura de leitura do capítulo como quem seguisse o comando do Líder. $\mathrm{O}$ fato de o professor assumir uma função é muito significativo do ponto de vista do processo do grupo, porque ele assumia junto com os alunos a tarefa 
implícita. Ademais, ele tinha livre acesso ao lugar do líder, pois além de seu aspecto institucional, ele sabia Física.

O professor, quando chegou à conclusão sobre a energia cinética, foi mais além na tentativa de verificar se o grupo havia entendido ou não os seus conceitos básicos:

Prof.- Que grandeza caracteriza o corpo em movimento, ... que grandeza um corpo em movimento ... o que só um corpo em movimento tem?

Ricardo - Só um corpo em movimento tem?

Tito- Aqui fala oh! ...

Ricardo -Energia!?

Tito-... o quadrado de velocidade

Prof.- $O$ quadrado da velocidade?

Tito- Tá aqui ó!

Prof.- Tá, isto é a fórmula, mas o que só um corpo em movimento tem? Energia pode ter um corpo que não está em movimento...

Valentim- Velocidade!

Tito- Ah! Velocidade!

Valentim- Obrigado! Obrigado!

Prof.- Então quando você fala em movimento (...)

O professor conduziu o grupo para que percebessem o que estava além da expressão matemática, assumindo a função de Questionador e ao mesmo tempo o papel de líder progressivo. O que nos parece mais interessante foi a conclusão do evento quando Valentim respondeu corretamente, pois este aluno não demonstrava participação nesse momento, não interagindo verbalmente, nem com o professor nem com alguém do grupo. Dizer a resposta certa, feito não realizado por nenhum outro aluno, representava para Valentim sua ascensão ao lugar do líder, já que estava estabelecida uma associação entre este lugar e saber Física.

A intervenção do professor nesse episódio foi importante na medida em que possibilitou o grupo a superar o seu dilema: era como se os alunos operassem sob as ansiedades básicas devido ao corte da árvore sem, no entanto, terem a canoa. A conclusão do professor, sobre o tema que tratavam (energia cinética) ajudou o grupo a superar o dilema vivido e a sustentar a esperança de construir a canoa. Após sua saída, o grupo se manteve por algum tempo na numa configuração quase difusa, da mesma forma quando o professor estava com eles. Dissemos quase difusa, pois Valentim tinha uma participação muito pequena. 
Após a saída do professor, é importante salientarmos o efeito de sua intervenção no grupo, sendo possível resgatar a idéia da intervenção virtual, no sentido de que a sua figura funciona como um objeto transicional da qual o grupo se utiliza para a manterem a esperança da construção da canoa. Observamos que esse evento ocorreu numa etapa seguinte, quando os alunos discutiam sobre a energia potencial gravitacional, mantendo a mesma forma de interação de quando o professor estava com eles. A figura a seguir ilustra o que estamos indicando.
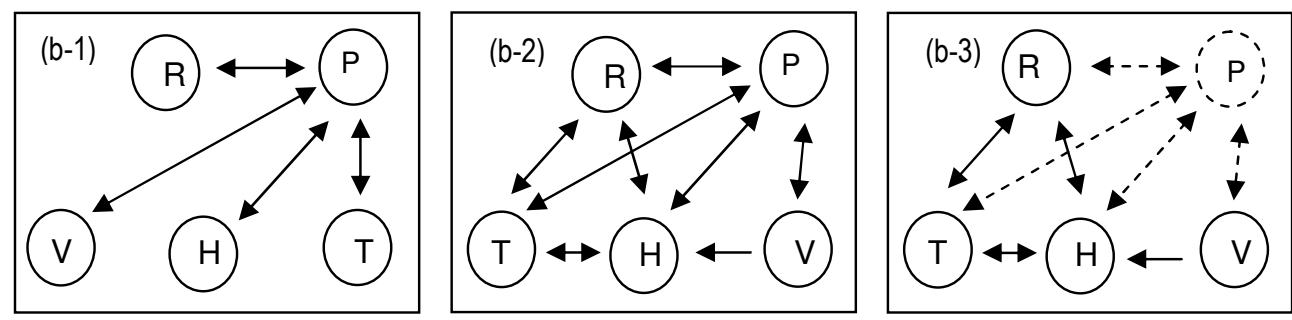

Fig. 16- Gráficos indicando as diferentes intervenções do professor, presencial e virtual.

Com o efeito, essa estrutura do grupo não é muito duradoura e diante de um novo dilema passou a vigorar um sistema de comunicação divergente, na qual Hernam oscilava entre uma liderança autocrática e laissez-faire, demonstrando pouco compromisso para com o grupo. Identificamos isto na fala a seguir:

Tito- Você fica aí, esperando eu falar aí!?!

Hernam- Tô ordenando aqui oh!

Tito- 'To ordenando!'... você não ordena nada!

Hernam- Ah! Eu falo, mas vocês não me obedecem!

(Valentim dá uma risada da forma como Hernam fala ao grupo)

Ricardo - Ordenando... você não ordena nem sua casa! ... Obedece!

Não é assim não! Ele pensa que vai falar e mandar!

Se houve no início da aula uma aceitação da liderança de Hernam, agora o grupo se manifestou contrário, mostrando-se indignado com a forma dele agir. O primeiro a se incomodar foi Tito, seguido por Ricardo. Seguido aqui tem um sentido mais amplo, pois como dissemos, era esse líder (Tito) que ele deveria seguir: esses dois alunos formavam um subgrupo cujo objetivo era manter a liderança de Tito, fortemente ameaçada pela autocracia de Hernam.

Valentim, ao contrário, não parecia se importar tanto com a forma de Hernam atuar no grupo e indicava a composição do outro subgrupo (Hernam e Valentim) para a manutenção da liderança de Hernam. Uma das causas dessa junção com este era porque 
Valentim, em outras aulas, mostrava-se insatisfeito com a liderança do outro, manifestando-se da seguinte forma: "é sempre Tito que faz tudo!".

Logo em seguida, o grupo relaxou, mas não permaneceu assim por muito tempo, pois se instaurava uma nova disputa entre Tito e Hernam, que teve sua gênese na discussão sobre a energia potencial gravitacional e sobre o que chegava ao solo primeiro, o mais pesado ou o mais leve, quando ambos eram largados simultaneamente de uma mesma altura. Então, Tito, que era o Anotador, foi o primeiro a dizer:

Tito - agente coloca a que energia potencial está associada a uma posição do corpo no campo gravitacional da Terra e agente coloca a energia potencial está relacionada a altura também, ou não?

Para Hernam, a massa do corpo era a principal característica. Ele afirmou:

Hernam- Tá associado à massa e a altura (fala com enfase)...Porque...porque dependendo do peso vai ter mais , mais... inércia. Quanto mais pesado, mais gravidade vai ...

Quando ele disse, sua idéia foi recebida com certo descrédito dos demais alunos que riram do que ele Hernam havia falado. Iniciava, então, o embate:

Tito- Nada a ver!

Hernam- Lógico que tem!

Valentim- Acho que tem! (fala para Tito apoiando Hernam)

Tito - Solta qualquer objeto (...)

Valentim - Como é?

Tito- Tá tudo errado que ele falou!

Hernam- Não tá nada!

Tito- Tá errado sim!

(...)

Tito- Tá sim! Taca uma bola (...)

Hernam- Taca uma bola de boliche, taca um avião e uma pena, qual chega primeiro?

(Há um silencio no grupo)

Hernam- É a Norma de Newton, lá,... Norma de Newton, né, Norma de Newton. (fala se referindo à alguma Lei de Newton).

Ainda que o embate ocorria ao nível do conteúdo, ele estava configurando uma nova busca pela liderança, pois como já vimos o papel do líder era adjudicado no grupo também pelo domínio do conteúdo. Entretanto, enquanto aqueles dois alunos argumentavam, abria-se espaço para a participação de Valentim e Ricardo e, por conta disso, o grupo experimentava um novo sistema de comunicação difuso, estando os 
alunos diante da possibilidade de experimentar um salto qualitativo para saírem da prétarefa.

Essa configuração do grupo pode ser caracterizada como um momento de aprendizagem em que, agregado ao conteúdo da atividade, encontrava-se a capacidade dos alunos de ouvir opiniões adversas, de argumentar a favor ou contra as idéias que surgiam, questionando-se mutuamente. Segundo Bleger "aprendizagem é uma modificação mais ou menos estável das linhas de conduta, entendendo-se por conduta todas as modificações do ser humano, seja qual for a área em que apareçam" (2001, p. $68)$.

Como Hernam não aceitara o que Ricardo e Tito argumentaram, ele emitiu um novo comando para que todos lessem o livro e tentassem entender melhor. Surgiu uma divergência na comunicação, como indicado na figura 14-c; o momento de comunicação difusa não fora muito longo.

A comunicação difusa e a divergente oscilavam no ambiente grupal, isto é, os alunos, ora conseguiam superar a estereotipia dos papéis resolvendo um dilema, ora surgia um novo comando de Hernam para que lessem o livro. Ora, ler o livro nos momentos de dúvida era como tentar agarrar-se à árvore que não mais existia, o que significa que Hernam não conseguia suportar as ansiedades de ver-se perdido em meio à discussão. Em outras palavras, Hernam interrompia o processo de pensar do grupo, tentando impor a leitura do livro, porque:

"Pensar equivale abandonar um marco de segurança (o livro) e ver-se lançado numa corrente de possibilidades (as idéias de Tito e Ricardo). No pensamento, o objeto e o sujeito sempre coincidem, e não pode 'remover' o objeto sem 'remover' $\mathrm{e}$ problematizar o sujeito; no medo de pensar está incluído o temor de passar ansiedades e confusões e ficar encerrado nelas sem poder sair. Ansiedades e confusões são, por outro lado, iniludíveis no processo do pensar e, portanto, da aprendizagem" (ibid, p.74-75). 
Podemos dizer que a configuração 14-c pode ser desmembrada da seguinte forma:
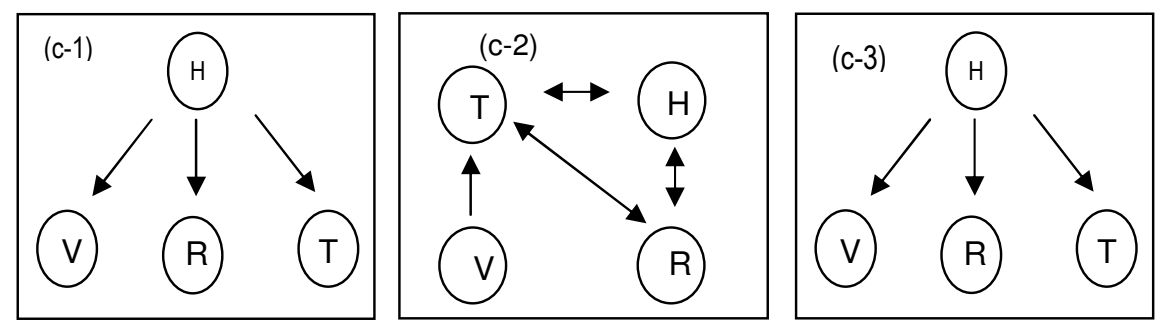

Fig. 17- Esquema indicando a liderança autocrática de $\mathrm{H}$

Durante as discussões sobre o tema, Valentim era quem menos participava verbalmente, e ainda, enquanto os outros discutiam, ele também sofreu uma exclusão, sobre tudo de Tito que lhe negou responder uma pergunta.

Valentim- Ó, aê! Quero fazer uma pergunta! (fala pata Tito)

Tito- Agora você vai esperar eu terminar!

Hernam- O cara não deixa o outro fazer um pergunta (fala olhando para a filmadora, de brincadeira, se referindo ao Tito)

Ricardo- É aí, o cara é mau! (também fala olhando para a filmadora)

Valentim- Que anotador é este?!?!

Ricardo- É! Questionador tem que questionar, é isto que está na lei!

Valentim- Que anotador é este?!?!

Depois de alguns instantes, Tito correspondeu ao chamado:

Tito- fala!

Valentim- $O$ quê?

Tito- o que você ia perguntar!

Hernam - Mas você não deu oportunidade para o cara!

Valentim- Você não quis responder na hora em que ia perguntar!

Tito- É!? (faz pouco caso da reclamação de V)... tenho culpa se vocês só fazem pergunta na hora errada!

Percebemos nesse episódio que Tito era atacado pelo grupo por não corresponder ao pedido de Valentim, mas esse movimento dos alunos contra Tito nos parece ter um sentido mais profundo: como Tito não aceitou tornar-se depositário do não saber Física do grupo, os alunos lhe atribuíram o papel de sabotador, por não respeitar a lei, que vigorava devido às funções. Quem mencionou o termo "lei" foi Ricardo, para justificar seu apoio a Valentim, já que este ocupava a função de Questionador, mas era como se dissesse a Tito: "você não pode não responder nem a 
mim, nem ao Valentim, você está sabotando as regras. Nós precisamos perguntar, e você tem por dever responder-nos".

Por outro lado, como havia no grupo um desejo latente pela liderança, podemos dizer que Ricardo e Valentim, que ficavam mais à margem do lugar do líder, aproveitaram esse momento para o ataque àquele que estava lá, para que tivessem uma chance, sendo em outros momentos não poderiam atacá-lo. Esse processo é semelhante a uma luta de classe na sociedade, em que os menos desfavorecidos almejam o que há na classe mais alta e para isso acusam quem está lá de não deixá-los usufruir tal como a elite.

A partir desse momento o grupo se dispersou, pois Tito fazia o seu exercício sozinho, Hernam deitou-se sobre sua carteira enquanto Valentim e Ricardo conversam sobre outras coisas. Mantiveram-se nessa configuração até que Hernam tentou incentivar que o grupo voltasse a resolver o exercício:

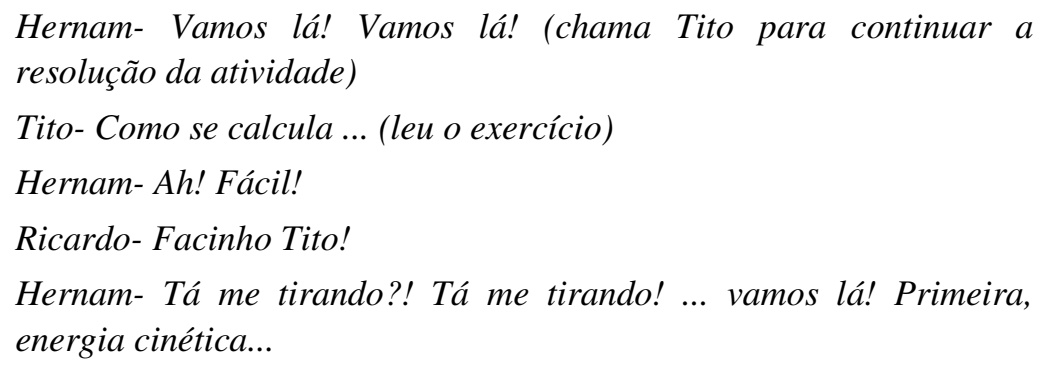

Ao ouvir energia cinética, Valentim logo se manifesta:

Valentim- "mv" ao quadrado dividido por dois!

Hernam- " $m v$ "?!

Valentim - Eu sei, é “mv” ... Ah! (ele fala para Tito e depois se irrita por não receber atenção)

Hernam- Energia cinética, coloca aí (fala para Tito)

Valentim- massa vezes acelera... massa vezes velocidade ao... tudo ao quadrado divido por dois (fala mais uma vez para Tito e depois reclama mais uma vez)

Então Valentim recorre ao pesquisador que estava próximo ao grupo e lhe fala:

Valentim- Sou o líder! Sou o líder!

Pesq.- Tem certeza?

Valentim- Tenho aí (mostra-lhe o livro) energia cinética é "mv" ao quadrado divido por dois.

A fala de Valentim é muito importante do ponto vista da nossa análise, pois ele assumiu o papel de porta-voz: "sou o líder" significa o desejo latente do aluno em 
assumir o papel de líder e a relação desse papel com o saber Física. Ele se declarou líder, após dizer corretamente a expressão matemática da energia cinética e a partir daí, ele participava mais ativamente de algumas discussões ou em alguns outros momentos parecia que tentava exercer o papel de líder, ao incentivar o grupo ou mencionar corretamente uma expressão de matemática.

Em outro momento, quando Tito, Ricardo e Valentim começaram a conversar sobre um assunto qualquer, Hernam os chamou para fazerem a atividade, gerando as seguintes fala no grupo (0.27.27):

\section{Hernam- Acelera aí! Acelera aí!}

Tito- Acelera?!? Acorda!!! (fala indignado com H, pois ele deitado sobre a sua cadeira)

Logo que Tito lhe respondeu, alguém do grupo das meninas o chamou para ajudá-las com uma questão, e então Hernam insiste uma vez mais com o colega:

Hernam- Acelera! (fala brincando)

Valentim- Pô, vamos fazer aqui, tamo no dois ainda!(fala para Tito que conversava com o outro grupo)

Hernam- Acelera aí! (fala para Tito puxando-o de volta para o grupo)

Hernam acompanha Tito na empreitada de ajudar as colegas, mas Valentim não se mostrava satisfeito e disse aos dois:

Valentim- O professor está ali pra quê? ... Ó, o pesquisador está ali...(se refere ao pesquisador pelo nome) Ó o ele está ali ó! Acelera! Acelera (insiste com o dois para deixar as meninas chamarem o pesquisador)

Ricardo- Vamos embora! Vamos embora! (aponta para o livro)

(...)

Hernam- (...) vamos fazer alguma coisa!

Tito- Eu tô fazendo!

Hernam- Eu também! (...) (fala alguma coisa que é não é possivel entender)

Ricardo-Trabalho (...) (lê o livro)

Valentim- Trabalho é a igual a força vezes delta ' $r$ ' vezes o ângulo (fala inicialmente para Hernam e depois para Ricardo)

Nesse episódio foi possível perceber: i) Hernam atuando como Líder, ora autocrático ora laissez-faire; ii) Tito não aceitando os comandos de Hernam, ele sempre rebatia o colega; iii) Ricardo e Valentim interagindo mais com os colegas. Sobre a atuação destes dois, dizemos que se trata de uma busca pelo lugar do líder, com maior destaque para Valentim, que passou a atuar assim, depois que se disse "sou líder". 
Quando o professor regressou ao grupo sua intervenção proporcionou novamente que grupo saísse da estereotipia e que Valentim e Ricardo fossem mais incluídos no processo de discussão. Contudo, é interessante notarmos que, antes de sua presença, o grupo passava pelos momentos de tensão entre Tito e Hernam. Em busca da resposta certa sobre a energia potencial gravitacional, os dois disputavam a liderança. Ricardo demonstrava-se ansioso pela situação e tentava iniciar a resolução da questão seguinte que tratava da energia potencial elástica. Valentim tentava, a todo custo, ocupar o lugar do líder. Começava, então, a surgir uma polarização da tarefa entre Hernam e Tito enquanto discutiam seus pontos de vista sobre a energia potencial gravitacional.

A forma como o professor dialogava com grupo permitia que os alunos fizessem conclusões sobre os temas em questão, anulando aquela polarização. Primeiramente sobre a energia cinética, logo em seguida sobre a energia potencial. Ao ver que o grupo pode ir mais além ele pergunta sobre a energia potencial elástica:

Prof.- E a elástica?

Valentim- Elástica é ... (faz gestos indicando o que ele queria responder, com um movimento semelhante a de quem estica um arco e flecha)

$R$ - (atropela $V)$ É quando olha a deformação...

$V$-... num arco e flecha.

Quem dava as repostas primeiramente era Ricardo, que estava mais ansioso com toda aquela discussão entre Hernam e Tito, acompanhado por Valentim, que sofrera a exclusão de Tito. Porém, aqueles outros dois alunos entraram na conversa com o professor e assim mais uma vez configurava-se uma comunicação difusa no grupo (alunos e professor).

Houve, também, uma tentativa do professor explorar mais conteúdo, fazendo perguntas que não estavam tão diretamente ligadas aos tipos de energia, mas eram necessárias para compreensão das mesmas. Ao proceder dessa forma, era como se ele quisesse iniciar um outro ciclo, tentando promover aqueles saltos qualitativos na espiral dialética, segundo o modelo de Pichon-Rivière (2005). Estes estariam associados às sínteses do conteúdo (energia cinética, potencial gravitacional e elástica) que ele favorecia aos estudantes, caracterizando um momento importante para a sua aprendizagem. 
Vimos na aula anterior que o professor solicitou que Tito ajudasse os seus colegas com exercícios, instituindo assim o lugar do líder como sendo dele, e que, segundo a nossa interpretação, impediu o grupo de experimentar momentos de integração do objeto de conhecimento. Porém, durante a intervenção que estamos tratando neste momento, o professor procedeu de maneira oposta à outra aula, ao pedir a esse aluno não respondesse tudo tão prontamente para que os demais tivessem uma oportunidade:

Prof.- $O$ que é uma grandeza física? (fala mais voltado para o Valentim)

Tito- são elementos que ...

Ricardo- ...elementos...

Prof. - Espera aí (fala para Tito) se não você vai direto, deixa eu ver se todo mundo sabe (Tito então dá um sorriso meio sem graça).

Ao pedir que esperasse, o professor também reconheceu Tito como líder do grupo, já que este papel está associado a saber Física e “ver se todo mundo sabe” em última análise pode significar uma relativização do lugar do líder no sentido de que outros alunos poderiam estar nesse papel. Embora, seja bem verdade que no momento de dúvida, sobre o conteúdo em questão, todos recorriam a Tito.

A partir desse evento é possível entender aquela reação de repulsa de Tito para com alguns alunos: ao mesmo tempo em que queriam tirá-lo do lugar do líder, e o professor o fez, também queriam colocá-lo sempre que lhes era conveniente. Então, era como se ele pensasse assim: “O pessoal é fanfarrão mesmo! Só me chamam quando eles precisam, preferem aceitar os comandos do Líder autocrático, que não sabe Física e fica mandando a gente ler o livro, a discutirem o problema".

Quando analisamos o processo do grupo é imprescindível que o professor se torne integrante do grupo, que em geral se dava ao assumir algum papel que lhe transferiam. Sobre essa última intervenção podemos destacar:

- Parece-nos que o professor havia percebido o que estava ocorrendo no grupo e corroborou com vontade dos alunos de assumirem algumas vezes o papel de líder (“deixa eu ver se todo mundo sabe”); 
- Identificamos o papel porta-voz que ele teria assumido, enquanto membro interino, ao enunciar a latência do grupo sobre ser ou não ser líder. Uma vez tendo a sua mensagem aceita, o professor passou a atuar como líder progressivo quando resolveu a tarefa implícita, superando os dilemas que corriam e alimentando a esperança de que alunos conseguiriam construir a canoa;

- Os ciclos estavam associados àquele assentamento do conteúdo oferecido pelo professor, porque para os alunos resolverem os problemas da energia potencial gravitacional não podiam estar com dúvidas sobre a energia cinética. E isto vale também para a energia potencial elástica e gravitacional. Não se trata de uma exigência de pré-requisitos ou de uma seqüência lógica, mas sim de uma exigência psicológica do sujeito que não consegue resolver um problema, se estiver preso a um outro anterior;

- O professor quando ofereceu aquelas sínteses veio ao encontro dessa ansiedade do grupo, reduzindo-a e permitindo momentos criadores, que caracterizam a fase da tarefa.

Após essa intervenção (Fig. 14-d), Tito e Hernam se juntaram para resolver sozinhos os exercícios sobre os quais o professor havia fornecido explicação minutos antes, configurando-se em um subgrupo. Como conseqüência, surgiu outro subgrupo,Valentim e Ricardo, que estavam distraídos enquanto os outros dois resolviam o exercício. Quando Ricardo percebeu que os dois já haviam terminado, reclamou que não entendia nada, falando enfaticamente e sendo acompanhado por Valentim.

Entendemos que se trata de um momento marcante no grupo que nos indica uma mudança: Ricardo assumiu o papel de porta-voz denunciando o subgrupo Hernam e Tito, tornando-se partir daí líder progressivo (Fig. 14-e) deste processo, quando obteve a concordância dos outros membros do grupo. Então, os outros dois retomaram a discussão a fim de explicar aos seus colegas o que haviam resolvido, formando um sistema de comunicação difuso no grupo (Fig. 14-f).

O professor passou rapidamente pelo grupo encontrando a configuração 14-f, mas naquele exato momento, Hernam, que tinha a função de Líder, estava deitado sobre a carteira, então o professor lhe disse:

Prof.- O Líder não comenta nada, fica dormindo? 
Então, prontamente Hernam se levantou e convocou os alunos para o resolverem exercício, havendo uma aceitação do que lhes foi pedido. Dois fatores colaboraram para a aceitação do grupo: a presença do professor e a forma não autoritária que Hernam convocara o grupo. Se instaurou uma telê de disposição e Hernam atuava um líder democrático, auxiliando o grupo, reproduzindo como o professora interviera nas vezes em que esteve com o grupo. A aula foi encerrada com os alunos experimentando uma configuração difusa, como indicamos na Fig. 18.
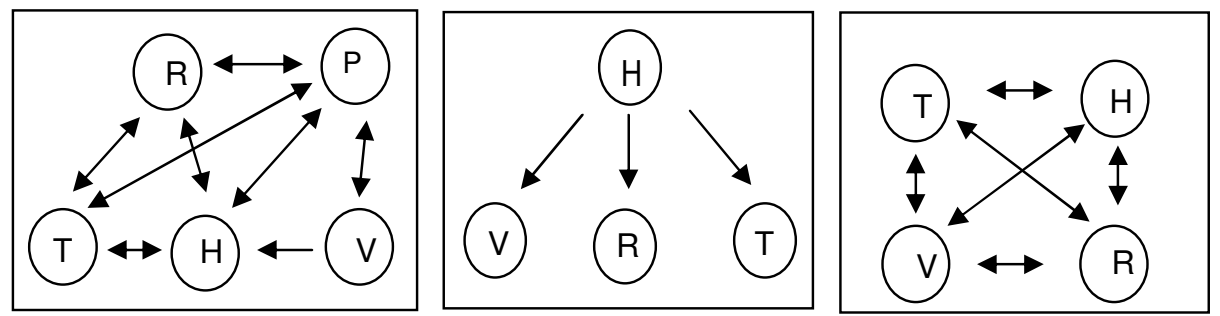

Fig. 18- Esquema indicando a assunção do papel de líder progressivo $(\mathrm{H})$ e logo em seguida o estabelecimento de uma Comunicação Difusa.

Na medida em que houve uma constante reformulação dos vínculos entre os alunos e professor e na rede de comunicação, podemos dizer que o grupo encerrou a aula num movimento de saída da pré-tarefa. As mudanças foram bem significativas, tanto em relação à aula anterior quanto do início para o final desta: as funções introduziram uma nova forma do grupo agir, promovendo uma circulação dos papéis; o lugar do líder estava disponível para aquele que soubesse Física, e os alunos em momentos e freqüências diferentes ocuparam esse lugar; as intervenções do professor foram no sentido de ajudá-los a saírem dos momentos esquizoparanóide e promover os saltos qualitativos; mas a mudança de líder autocrático para o democrático nos parece ser a mais significativa nesta aula.

Por fim, parece-nos que o grupo seguiu o caminho da operatividade, seguindo a trajetória de uma espiral dialética cuja síntese era um ponto de partida para uma nova situação que exige uma nova conduta para superar o novo dilema. Então, nesses momentos entravam em cena as ansiedades básicas do medo da perda e do ataque (era quando Hernam pedia que todos lessem o livro): medo de cortar a árvore (liderança de Tito) e medo de construir a canoa (outro ocupar o lugar do líder). Os alunos encerraram a atividade, tendo superado minimamente a tarefa implícita $\mathrm{e}$ intercambiavam os papéis entre eles. O efeito colateral de se ocupar o lugar do líder 
era que aprendiam, ainda que superficialmente, o conteúdo estudado, pois para ocupálo era necessário saber Física.

\section{3-O grupo da dependência}

O grupo da dependência, que é o grupo 1, foi único na classe que sofreu duas modificações ao longo do ano, a saída de Janaína após o $2^{\circ}$ bimestre e a entrada de Eugênia no último bimestre, e permaneceu composto por três membros durante o $3^{\circ}$ bimestre. Além dessa peculiaridade, era o único grupo feminino na turma, intitulado por elas como "grupo da Luluzinha".

Quando elas se disseram "somos o grupo da Luluzinha", foi em um tom de comemoração pelo retorno das atividades em grupo, pois era a primeira aula após retornarem das férias do meio de ano. Os sentimentos expressos naquele momento da aula podem significar um desejo de estarem reunidas com os semelhantes ${ }^{18}$ da turma: meninas e minoria.

Utilizamos para análise duas aulas, porém, uma terceira será considerada de forma mais geral para nos auxiliar na análise. A primeira, aula 5, ocorreu no primeiro bimestre, quando Janaína ainda estava presente; a segunda, aula 12, estavam somente as três. A aula 16 é a complementar, quando Eugênia compunha o grupo.

Entre as alunas, Janaína assumia o papel de líder autocrática, com a aceitação das colegas. Após sua saída, não parece que alguém teria assumido seu lugar, ainda que tenhamos observado um embate entre Rebeca e Camila por esse lugar, enquanto que Carmem parecia se aliar mais a Camila do que com a outra colega.

Na última aula, Eugênia compunha o grupo, mas era como se não existisse, pois somente em dois momentos lhe dirigiram a palavra durante a execução da atividade, e no final, Camila pediu que ela entregasse a folha de resolução do grupo ao professor. Mesmo este, só tentou chamá-la para o dialogo e para integrá-la ao grupo uma única vez.

O contexto da aula 12 foi marcado por dois eventos importantes, ambos antes da formação dos grupos para a atividade: um comentário do professor sobre como estudar e quais etapas que os alunos deveriam cumprir para a obtenção de bons resultados e a instituição das funções que os alunos deveriam cumprir nos grupos. Dessa forma, as

\footnotetext{
${ }^{18}$ Vide sobre as formas de grupalidade no capítulo do referencial teórico.
} 
funções podem ser vistas como uma extensão do seu comentário, cujo objetivo era favorecer a aprendizagem dos alunos nos grupos cumprindo as etapas que ele mencionou em sua fala.

A relação das alunas com a Física nos levou a caracterizá-las como o grupo da dependência do professor, pois elas assumiram que não sabiam Física e que não poderiam resolver os exercícios, sendo Carmem a que mais se expressava. Suas afirmações de que era incapaz de resolver os exercícios e as recorrentes propostas para chamar o professor ou o pesquisador para auxiliá-las, fazem de desta aluna a porta-voz que o grupo tinha do professor.

$\mathrm{Na}$ aula 12, a experiência do grupo pode ser traduzida como de abandono, devido a não presença do professor, ao contrário da aula 16, na qual o clima foi de alegria. A justificativa era a constante presença do professor, que compactou com o grupo tanto no que diz respeito a esse clima quanto à exclusão de Eugênia. Se na aula 12 elas sentiam-se desoladas, distantes do professor, na outra estavam completamente alegres, pois o professor pertencia ao grupo, e ele revela isso.

De uma forma geral, consideramos que este se trata do grupo da dependência, e por isso não atingem a fase da tarefa, embora não se caracterize completamente como pré-tarefa. Aquele embate entre Camila e Rebeca tem um sentido mais amplo, no sentido da manutenção do grupo porque elas representam forças antagônicas, em que de um lado, Rebeca apontava para mudança enquanto do outro Camila esforçava-se para manter a dependência. Parece-nos, então, que o equilíbrio dessas forças é mantém o grupo unido.

\subsection{1-Aula 5: descrição $(03 / 06 / 2004)$}

Utilizamos a descrição dividindo a aula em episódios cujas marcações se referem ao número da aula e a uma cronologia da mesma. Porém, a aula 5 é uma exceção a esse sistema que criamos, por se tratar de uma apresentação do grupo para toda a classe, o que significa que as alunas não ficaram o tempo de uma aula reunidas para resolverem um atividade.

\section{$5.1^{19}$-Apresentação do grupo sobre a $2^{\mathrm{a}}$ lei de Newton}

\footnotetext{
${ }^{19}$ Essa numeração está relacionada aos episódios. No caso, 5.1 significa o primeiro episódio da aula 5. A mesma regra é válida para os outros episódios e aulas.
} 
Nesta aula não teve uma atividade para ser resolvida em grupo como em geral ocorria. Os grupos se formaram para a apresentação Leis de Newton que já haviam sido preparadas, sendo que cada grupo ficou incumbido de uma. No caso do grupo 1, as alunas apresentaram a $2^{\mathrm{a}}$ Lei. Os alunos do grupo 2 já haviam apresentado a $1^{\mathrm{a}}$ lei e os do grupo 3 apresentaram logo após as alunas a $3^{\mathrm{a}}$ lei de Newton.

Cada grupo tinha que ir a frente dos colegas (do professor e do pesquisador) para a apresentação do que se tinha preparado. Para sua exposição, as alunas estavam encostadas na lousa de tal forma que Janaína mantinha uma pequena distância em relação às colegas, até que se juntaram em forma de círculo para discutirem algo sobre a sua apresentação. Nesse momento quem mais falava era Camila, que parecia explicarlhes algo. Contudo, ao terminarem essa reunião, voltam à configuração de antes.

O professor escolhia um aluno do grupo para que iniciasse a apresentação e em seguida o próprio grupo ia seguindo a sua dinâmica própria. Quando as alunas já estavam prontas, Janaína perguntou ao professor quem deveria iniciar, e este escolheu Carmem, que ao ouvir seu nome ficou constrangida e tímida para a realização de tal tarefa; a outra parecia frustrada.

Quando ela ia começar a falar, Janaína a convidou para que desse um passo a frente em relação ao grupo para que se destacasse. E com muita timidez ela iniciou:

Carmem- A força que nós estudamos depende... a distância que ela vai percorrer depende da força que vão aplicar nela, se eu vou ... (risos que a turma lhe provoca) se... eu estou com uma borracha, se eи vou aplicar, atirar ela, ela vai longe (faz gestos indicando que a borracha seria lançada longe). E se eu jogar ela, ela vai menos perto (indica um lançamento próximo) ...(risos)... mais perto, depende da força que eu aplicar no objeto.

Após falar isso, transpareceu que não tinha mais nada a dizer e quem assumiu a fala do grupo foi Janaína, que atuou desta maneira em outras situações em que o grupo se encontrava em dúvida, ou não tinha o que falar.

Janaína- É, a segunda lei é essa! Depende da força que aplica no objeto, é a ... distância do objeto, é a...

Kevin- Nem sei que lei você esta falando! Qual é a lei?

Janaína- É a segunda lei (responde com ênfase), não?

Kevin- Como chama? Como chama?

Janaína- Não tem nome! Não é professor? Não tem nome! Só tá escrito $2^{a}$ lei de Newton, não tem nome!

Prof.-Pode ser chamada de Principio Fundamental da Dinâmica. 
Janaína- Tá! Principio Fundamental, fala que... depende... isto é, a distancia que um objeto é lançado, ele depende da força que lanço, a distância que ... a força que eu mandar é força que ele vai, então vamos supor, se eu pego qualquer coisa... borracha e jogo longe, jogo com muita força, esse objeto vai longe (pausa mais prolongada). E também por causa do atrito, com quanto mais força eu jogar... (o falatório da turma a interrompe), menos atrito ela vai ter, né? Você vai com atrito (...) e ele vai mais longe. E se eu jogar com menos força ela vai mais perto, por, por jogar mais fraquinho assim (fazo gesto indicando). Ele vai ter mais força, vai ter um atrito maior e vai ficar mais perto da gente, vai cair mais perto!

Enquanto falava, Janaína olhava para o professor a maior parte do tempo e assim que terminou, as perguntas dos outros alunos da classe começaram a surgir com o tema principalmente sobre o atrito. Sempre Janaína que se incumbia de dar as respostas aos colegas. A sua posição em relação às outras alunas do grupo não mudou, ela se destacava em relação a elas. Nesses momentos de perguntas e respostas, o professor pouco intervinha, mas por fim, ele tomou a palavra e sintetizou sobre o que os alunos haviam discutido.

Enquanto o professor falava, as meninas do grupo 1 se preparavam para apresentar uma experiência para tentar demonstrar o que foi falado por Carmem e Janaína, o que na prática foi o mesmo. Nesse meio tempo, Gomes pediu autorização ao professor para fazer perguntas ao grupo que apresentava e nem mesmo elas haviam terminado a preparação para a experiência, Gomes as bombardeou com perguntas:

Gomes- Ei! Ou! Eu vou perguntar vocês se mandam!

Janaína- Ué! Pode perguntar!

Gomes- Tá! Tenho dois corpos de pesos diferentes, só que com tamanhos diferentes e arremessei com a mesma força, eles vão cair no mesmo lugar?

Janaína e Camila- Vão!

Gomes- Âh!

Janaína- Porque ái não depende do peso!

Gomes- Tamanhos diferentes! Pesos iguais!

Janaína- O que importa não é o tamanho!

Gomes- E o atrito?

Prof.- Pera aí! Pera aí! De novo, de novo! Você tem dois?

Gomes- Dois corpos de mesmo peso, tamanhos diferentes e jogo eles com a mesma força. Eles vão cair no mesmo lugar?

Prof.- Jogo eles como?

Gomes- Arremesso! 
Janaína- Mas aí, é meio assim, porque até onde eu estudei... (fala olhando para o professor)

Prof.- Você está judiando delas com essa pergunta! Você estava estudando antes... você está misturando movimento horizontal.

A turma toda se envolveu no problema, gerando uma confusão entre os alunos, pois uns falavam para tentar solucionar o problema outros para fazer algum tipo de comentário ou ainda alguns aproveitam o momento para fazer piadinhas sobre o tema. Gomes, então, tentou se justificar, mas como todos falavam juntos não foi possível ouvir o que ele dizia. Assim foi, até o que professor pediu que cada um falasse na sua vez, a fim de organizar a discussão.

Depois da celeuma gerada, quem respondeu à "dúvida” de Gomes foi Janaína, ainda que não demonstrasse segurança ao falar. Em seguida, o professor perguntou se Gomes se dava por satisfeito e este respondeu que sim apenas com um sinal positivo com a cabeça. Passado esse momento mais agitado da turma, o professor aproveitou a questão discutida anteriormente e perguntou ao grupo 1:

Prof.- E se tirar o atrito?

Janaína- Aí as duas ... as vão juntas!

O grupo retomou a preparação da experiência a ser realizada na classe e Janaína estava à frente dessa situação. Porém, o que elas haviam escolhido fazer não deu certo e essa mesma aluna resolveu tomar a frente, mais uma vez, e improvisou uma experiência. Assim, enquanto ela apresentava, as outras alunas somente assistiam tal como a classe. Sua apresentação foi interrompida por uma pergunta que Tim fizera ao professor e este repassou para o grupo.

Ao responder, Janaína se posicionou como no inicio da apresentação, a uma certa distância das colegas e se mantiveram assim por algum tempo. A apresentação da experiência foi interrompida pela pergunta de Tim e não teve seqüência, pois a turma iniciou uma nova série que questões ao grupo. Contudo, era o professor quem respondia aos alunos e ao término desse ciclo de perguntas e respostas ele resumiu o que dizia enunciando a $2^{\mathrm{a}}$ lei de Newton, pois ninguém do grupo o havia feito.

O professor, antes de encerrar a apresentação das meninas, pediu que elas também enunciassem a $2^{\mathrm{a}}$ lei, escrevendo-a na lousa. Surpresas com o pedido do professor, recorreram ao livro, pois não sabiam escreve-la. Alguns alunos também se mobilizaram para ajudá-las enquanto outros lhes cobravam, ainda que em tom de brincadeira, como era possível que não soubessem o que estavam apresentando. 
Então, o professor fez mais uma pergunta:

Prof- $O$ que é força resultante?

Janaína apontou para Rebeca responder já que ela estava com o livro aberto em suas mãos, mas todas elas se envolveram na resposta, falando ao mesmo tempo.

Prof.- Calma, vocês estão falando tudo junto! (pausa) Ó, tem uma fórmula ali na lousa com três termos. Explica pra nós o que é cada um deles!

Para atender ao pedido do professor houve uma participação mais efetiva do grupo: Carmem escreveu equação da segunda lei de Newton, enquanto que Rebeca tentava explicar cada termo:

Janaína- Pode explicar, eu já falei demais!

Camila-Resultante é a força total.

Quem explicou efetivamente o significado da força resultante foi o professor, mas à medida que explicava as alunas do grupo se dispersavam com outras atividades: Janaína brincava com a bolinha que ia usar na demonstração e Carmem a acompanhava, Rebeca e Camila conversavam. Ao término de sua explicação, perguntou o significado de "m" na equação.

Prof.- (...) o que é "m"?... Grupo, o que é "m"?

Janaína- $O$ que é " $m$ "? (fala para colegas responderem)

Carmem e Camila- É a massa!

O professor também fez uma explicação sobre esse termo da equação e em seguida perguntou as alunas sobre o último termo, "a" (aceleração). Em coro, o grupo respondeu que era a aceleração. A apresentação terminou, pois o professor perceber que os alunos da turma e mesmo as alunos do grupo não estavam interessados com o tema, e em seguida chamou o grupo 3 para apresentarem a $3^{\text {a }}$ lei de Newton.

\subsection{2-Análise da aula 5}

Esta aula foi a apresentação dos grupos e o que apresentamos é referente ao grupo 1. Trata-se de um período curto de formação grupal das alunas, mas ainda assim foi possível extrair informações importantes para a compreensão do seu processo e sua relação com as intervenções do professor. 

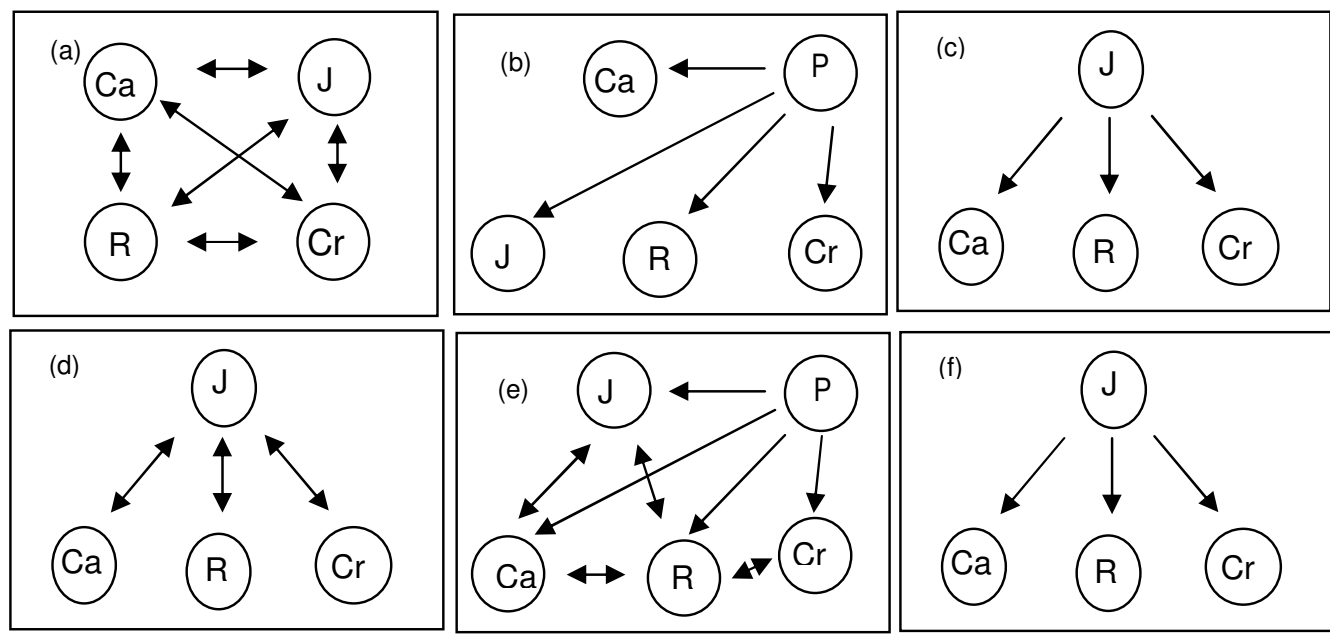

Fig. 19- Esquema indicando a história do grupo nesta aula.

O primeiro momento do grupo, antes da apresentação foi marcado por uma comunicação difusa entre as alunas quando elas formaram um círculo para discutirem os últimos detalhes. A formação circular pode nos indicar aquela noção ontológica de grupo que apresentamos no capítulo anterior trazendo a idéia de uma igualdade entre seus membros, reforçando assim nossa idéia inicial referente à figura 19-a. Contudo, parece-nos que o grupo no primeiro semestre era marcado pela forte liderança de Janaína, como ficou claro nesta aula.

Para a apresentação dos grupos, o professor escolhia um aluno para iniciar a apresentação configurando-se numa intervenção institucional, a qual representamos na figura 19-b. Quando o grupo esperava a sua indicação de quem começaria a exposição, Janaína lhe indagou sobre isso, esperando que ela fosse a eleita. Era como se ela perguntasse a ele: "Sou eu a escolhida para iniciar?".

No entanto, o professor escolheu Carmem, a qual recebeu o convite com muita surpresa. Esta aluna era a que mais apresentava dificuldades com Física e era quem mais dependia das outras alunas para ajudá-la na resolução dos exercícios durante as atividades de grupo. Na aula 5, sua apresentação inicial estava insipiente, certamente um tanto pelo nervosismo, outro tanto pela sua dificuldade, que ficará mais evidente nas aulas 12 e 16.

Notamos que depois da apresentação inicial, quem mais falou em nome do grupo foi Janaína, assumindo o papel de líder autocrática ao repetir o que Carmem já havia dito e responder as perguntas que os outros alunos fizeram (figura 19-c). Além disso, 
sua disposição em relação às colegas também indicava o tipo de liderança que ela havia assumido: ela estava mais distante das outras alunas, se destacando em relação a elas.

É possível observar ainda que quando Carmem iniciou a sua apresentação, Janaína pediu para que ela desse um passo a frente, para que estivesse em destaque, tal como ela estaria se estivesse falando. Se admitirmos que a pergunta que Janaína fez ao professor sobre quem iria começar indicava que ela deveria ser eleita, podemos considerar que Carmem se tornou depositária do desejo de colega de exercer a liderança.

Durante a preparação da experiência Janaína manteve-se como líder autocrática do grupo indicando o que cada uma devia fazer e era a ela que as outras alunas se dirigiam para esclarecimentos de dúvidas, tal como indicamos na figura 19-d. Nesse processo, houve uma combinação entre o papel assumido por Janaína e o necessitado no grupo, pois pelo que nos parece, as outras alunas não tinham tanto domínio do conteúdo permitindo a liderança autocrática de Janaína.

Naquele momento da aula em que o professor surpreendeu o grupo pedindo para enunciar a $2^{\mathrm{a}}$ lei de Newton, elas se desesperaram gerando uma confusão no grupo porque não se tinha uma estratégia de resolução para a tarefa que receberam. Então, quando o professor lhes dirigiu a palavra, ele assumiu o papel de líder progressivo ao ajudá-las a superar aquele momento em que operavam sob as ansiedades básicas da perda e do ataque: medo de perder a liderança sob a qual estavam salvaguardadas $e$ do ataque do novo, pois não haviam preparado nada e tinham de improvisar, o que expunha a fragilidade do grupo. De fato houve o ataque, pois alguns alunos as questionavam sobre não saber o que apresentavam. Ainda podemos dizer que o grupo experimentava a afiliação, pois não conseguiam se articular.

A liderança do professor foi importante porque estipulou uma forma de resolver a tarefa:

- manter a calma e organizar a rede de comunicação do grupo;

- observar a fórmula escrita na lousa e reparar os seus três termos;

- explicar cada termo da expressão matemática $(\mathrm{F}=\mathrm{m} . \mathrm{a})$.

A figura 19-e nos mostra como o professor interveio durante o processo e como o grupo se organizou em seguida Podemos dizer que se estabeleceu uma intervenção presencial, por causa dessas características supramencionadas proporcionando uma 
organização no grupo. Como vemos na descrição da aula, as alunas se articularam para cumprirem a tarefa explícita cujo vetor era de pertinência, cooperação e a comunicação não estava fechada somente em Janaína.

E em seguida, Janaína assumiu o papel de líder laissez-faire, ao indicar o que as outras aulas deveriam responder, como se observa na figura 19-f. Novamente se estabeleceu um sistema divergente de comunicação quando Janaína dava os comandos para indicar quem deveria responder ao professor, porque ela já tinha falado demais. Entendemos ainda que a sua fala-"pode explicar, eu já falei demais"- contenha um outro significado: “pode explicar, porque isso eu não sei!”. O não saber de Janaína está relacionado à segunda lei de Newton que pôde ser percebido quando Kevin lhe perguntou de que lei ela estava falando e não soube enunciá-la. Essa mesma dinâmica ocorria para a explicação de cada termo da fórmula da $2^{\mathrm{a}}$ lei de Newton.

\subsection{3-Aula 12: descrição (16/09/2004)}

Tal como procedemos com a aula anterior, utilizamos a descrição dividindo a aula em episódios cujas marcações se referem ao número da aula e a uma cronologia da mesma. Acrescentamos junto ao título dos episódios uma marcação de horas, minutos, segundo, nesta ordem, a fim de oferecer uma noção temporal dos eventos.

\section{1 ${ }^{20}$-Momentos Iniciais $(\mathbf{0 . 1 3 . 4 0 )}$}

A atividade em grupos teve início logo após um teste, que ocorreu no início da aula. Ainda foi marcada por uma fala do professor sobre como estudar e a explicação sobre as funções (Líder, Anotador e Questionador) que a partir daí deveriam nortear o trabalho em grupo nas aulas.

Quando elas perceberam que seriam filmadas, manifestaram-se contrárias. Inicialmente, fizeram comentários em tom de brincadeira sobre isto. Então Carmem disse:

Carmem- Desliga isso aí, né! Desliga isso, né!

Pesq.- Hoje vocês serão as escolhidas (risos)

Camila- Ah! Vou ficar de costas para não aparecer! (risos)

Pesq.- Pode deixar que vocês nem vão perceber, vou ficar de longe.

\footnotetext{
${ }^{20}$ Idem à referencia anterior.
} 
Quando as alunas já estavam reunidas no grupo, iniciaram a divisão das funções. Antes, porém, Carmem escrevia os nomes na folha, mesmo que oficialmente não fora designada para tal função. Feito isso, comentou em voz baixa com Camila, que estava ao seu lado, que não sabia nada do exercício e olhou em direção à filmadora que ainda estava sendo ajustada pelo pesquisador. Em seguida, falou mais uma vez:

Carmem- Eu não sei fazer, nem adianta que eu não sei...

Camila- Nossa, você nem leu ainda!

Carmem- Mas eu não sei, nem adianta, sou péssima! ... Quem é o líder (altera o tom de voz)

Camila- Não sei!... A Rebeca...

Quando Camila falou o nome da colega, juntamente com Carmem ficaram olhando para a indicada para a função, a qual não lhes respondeu nada e as olhava com cara de pouco agrado, não aparentando muita disposição para tal.

Camila- Ah! Mesmo com essa cara de chata aí... Rebeca!

Em seguida, Rebeca pediu a folha do enunciado do exercício para poder lê-los e Carmem que ainda escrevia os nomes interrompeu seu oficio e entregou-lhe a folha.

Camila- Por que não escreve os nomes primeiro e depois ela lê?

Carmem- Ela pediu e entreguei!

Após esse evento, seguido de um rápido momento de descontração, o humor de Rebeca mudou e ela passou sorrir mais e interagir melhor com as colegas.

Rebeca- Quem é o Questionador? Você é o questionador? Não sou eu

o Questionador?

Carmem- Não, ela (Camila) falou que você era Líder

Rebeca-Mas sou eu pergunto sempre!

Carmem e Camila- Ah! Não... vai assim mesmo!

Enquanto terminavam de discutir sobre as funções no grupo, o professor fazia um comentário geral para todos os alunos, orientando como deveria ser feita uma etapa do exercício. A reação de Carmem ao ouvi-lo foi de por as mãos no rosto como quem estava em desespero.

\section{2-Início da atividade (0.16.30)}

Carmem iniciou a leitura do exercício, primeiramente para o grupo, e depois para si mesma. As outras alunas demonstraram dificuldade para compreender o que estava sendo pedido no exercício, de tal forma que a folha com o enunciado do mesmo 
começou a circular entre elas, na tentativa de alguém entender. Durante essa movimentação da folha, Rebeca disse brincando, para exercer a sua função de Líder:

Rebeca- Olha o tempo! Olha o tempo!

Logo em seguida, Carmem começou a reclamar de tudo, a começar pela Física, em seguida do exercício afirmando que não entendia nada e tudo lhe parecia muito difícil, portanto, não conseguiria realizar a tarefa. Concluiu sua reclamação abrindo o livro e dizendo com ênfase que não gostava daquilo.

Carmem- Eu não gosto, não dá!

Rebeca- Eu gosto, pena que eu sou burrinha

Carmem- Mas eu não sei, não dá!

Camila- Fala isso com o professor de Física, ele tá ali!

Em seguida, elas ficaram ainda tentando entender o enunciado da questão, de tal forma que enquanto Rebeca mantinha a folha em suas mãos para lê-la, as demais folheavam o livro para encontrar alguma solução ou exercício semelhante para ajudálas. Nesse ínterim, Rebeca apanhou outra folha, com anotações suas e rabiscos, na qual tentara resolver outro em exercício enquanto estudava em sua casa. Ela mostrou a Carmem, que parecia mais desesperada e lhe disse:

Rebeca- Olha, eu to estudando!

Carmem- Você estuda, heim?!

Rebeca- Bonito, né? Fiquei brava, e daí eu comecei a rabiscar tudo... é que eu fico nervosa, dai eu perco o controle das coisas...

Carmem- Por que você fica nervosa? (oscila entre conversar com a colega e se concentrar na tarefa)

Rebeca- Eu fico nervosa porque eu tento, tento e dá errado! Eu fico nervosa (fala com mais ênfase), é incrivel!

Camila- Por que vocês não param de falar e resolvem?

Rebeca- Eu to procurando.

Rebeca foi a última a buscar o livro para procurar alguma solução e ajudar as colegas.

\section{3-Momentos de dispersão e intervenção do pesquisador (0.19.00)}

Depois que Camila pediu que parassem de falar, Rebeca e Carmem ficaram em silêncio, cada uma tentando fazer alguma coisa, estando ambas com os seus livros abertos, até que Carmem fez um comentário com Camila e as duas começaram a cochichar. Rebeca ficou curiosa para saber o que as colegas comentavam e porque tinha que ser em sigilo. Quando ia contar-lhe o que cochichavam, Camila lembrou que estava 
sendo filmada e escreveu num pedaço de papel o que ela queria dizer para Rebeca. Enquanto Camila escrevia, Carmem olhava algumas vezes para filmadora e foi então que ela viu o professor com outros alunos e comentou:

Carmem- Ó, o professor tá explicando para eles essa questão então ele vai explicar para nós também!

Rebeca- Vamo chamar ele! (aponta para o pesquisador)

Quando Rebeca se referiu ao pesquisador como alguém para ajudar-lhes, Carmem se mostrou envergonhada, mas mesmo assim a primeira o chamou até o grupo.

Camila ainda estava escrevendo aquele bilhete para Rebeca, cujo conteúdo devia ser o que se cochichava, quando o pesquisador chegou ao grupo. Esse fato foi motivo de risos entre as alunas, porque Camila foi surpreendida com chegada dele. Quem tomou a frente para lhe falar foi Rebeca:

Rebeca- A gente não entendeu! (risos entre elas, pois estavam acanhadas)

Pesq.- Não entendeu o quê? (risos da Camila e da Carmem)

Rebeca- Assim... como a gente vai começar a fazer?

Camila- Ah! Com lápis! (fala ironizando com a colega)

Rebeca- Não! To falando...

Então, o pesquisador tentou explicar-lhes, indicando como deveriam proceder com aquele item através de exemplos. Inicialmente ele falou somente com Rebeca, quem o chamou, mas Carmem também entrou na conversa. Por fim, ele perguntou se estava tudo certo e se elas haviam entendido e se pôs a disposição para novamente ajudá-las, se elas precisassem. 


\section{4-Estimando o valor do trabalho $(\mathbf{0 . 2 2 . 4 5})$}

Após a saída do pesquisador, as alunas começaram a procurar mais coisas referentes ao exercício no livro. Elas se mantiveram alguns instantes nessa empreitada, até que Rebeca lhes dirige a palavra:

Rebeca- Para a gente dar uma estimativa do trabalho, a gente tem que ver o que é trabalho! O que é trabalho para vocês?

Carmem- Pera aí rapidinho! (responde enquanto resolvia um outro assunto com Camila)

Como ninguém lhe deu atenção, pois estavam tratando de outra parte da atividade, Rebeca olhou a hora (ela era a Líder, responsável pelo controle do tempo) e tentou entender sozinha, se concentrando na leitura do seu livro. Até que novamente, depois de um tempo de leitura, ela tentou explicar para as colegas ele havia entendido sobre aquele tema:

Rebeca- Então, trabalho é a força num espaço... que num... eu vou daqui até ali, qual o trabalho que eu tenho? ... eu acho

Camila- É! (responde sem muito interesse)

Carmem e Camila não deram atenção a Rebeca porque estavam muito envolvidas com outra parte da atividade. Essa situação permaneceu assim até que a mesma aluna insistiu com o que ela estava lendo sobre trabalho e mais uma vez leu a sua definição para outra duas alunas. Após essa tentativa, obteve uma resposta que não lhe fora tão indiferente envolvendo as colegas e as três passaram a discutir o mesmo assunto trazido pela Rebeca. Elas permaneceram discutindo, na tentativa de estimar um valor para o trabalho, ainda que não chegassem a resposta alguma.

Rebeca- A gente tem que estimar um valor da força...

Camila- Âh?

Rebeca- ... um valor do espaço e um valor do cosseno, multiplicar tudo pra gente ter uma estimativa do trabalho.

Camila- Por quê? ... Por que isso aqui? (aponta para o livro)

Rebeca- Porque segundo aqui (também se refere ao livro) tá o trabalho é a força vezes a variação do espaço, vezes o cosseno.

Carmem- O problema é o valor do cosseno!

Camila- Não depende, aqui é o trabalho é constante.

Rebeca-Aqui é variável.... é estranho a gente ter que definir trabalho

Carmem- Muito estranho ( faz um sinal de negação com a cabeça)

Depois disso, surgiu um momento de silêncio no grupo, pois elas não tinham a resposta e nem sabiam muito bem como alcançá-la. Camila, enquanto grupo silenciava, 
parecia que tentava achar uma solução, pois fazia contas mexendo os seus dedos e falava baixo como quem pensava consigo mesma. Com o passar do tempo, elas começaram a ficar mais impacientes e reclamavam dessa situação que vivenciavam. Uma das reclamações era que o professor estava demorando para passar no grupo delas e quem a fez foi Camila. Logo em seguida, Rebeca leu mais uma vez o enunciado do exercício e mais uma vez falou ao grupo:

Rebeca- Mas como a gente acha o valor da força?

Carmem- Ãh?

Rebeca- Como a gente acha o valor da força?

Carmem- Estimando!

Rebeca- Tá, ... mas como?

Carmem então tentou dar uma resposta para a sua colega, mas não conseguiu, demonstrando também estar em dúvida sobre o assunto. Ela mostrava, porém, que sua dúvida era maior ainda, pois não sabia o que era força, pois perguntava se o valor de $500 \mathrm{Kg}$ era força ou não.

O grupo então passou a vivenciar um estado de ansiedade gerado pela dúvida que se estabelecera e a demora do professor. Era perceptível a impaciência da Camila com a situação gerada e parecia que aumentava à medida que Rebeca e Carmem demonstravam estar mais perdidas ainda:

Carmem- É tem a força também ... se aqui é $500 \mathrm{~kg}$ (no livro) a força tem que ser maior, não é? A força que puxa não é de tração?

Rebeca- Depende da força também, não é? ... No caso do elevador é a tração de um cabo ... aqui só tá a força, mas tem zilhões de forças. Tá muito vago isso pra mim! To falando sério, tem uma coisa pra cada... ( $n$ ão completa a frase).

Mesmo estando impaciente com a situação, Camila, que somente acompanhava as colegas, entrou na discussão para tentar achar uma solução para o problema, que passou a ser das três. Contudo, tinha uma entrada parcial no ataque ao problema:

Rebeca-Trabalho de uma força constante... (segue lendo o livro)

Camila- Então é isso, ... é pera aí que eu to aqui pensando (risos), quebrando a cabeça... por que isso aqui, trabalho de uma força constante? Então agente tava vendo isso?!

As três passaram a discutir possíveis soluções e estimar valores para o deslocamento, pois no problema havia um elevador que subia do quinto para o nono andar, cujas distâncias entre os andares deveria ser estimada. A discussão mudou para o deslocamento, saindo de foco o trabalho. 


\section{5-Estimando o valor do deslocamento (0.29.00)}

O grupo passou a discutir sobre o valor do deslocamento do elevador, o que marcou um novo momento a partir do qual as três alunas tinham voz nas discussões. Essa mudança ocorreu, sem que o tema trabalho estivesse resolvido.

Rebeca- Ele tá parado aí (se refere ao elavador do exercício)

Carmem- Não ... (responde com incerteza) ... faça uma estimativa ... (rele o problema).

Camila- (depois da releitura de Carmem) Para levar ... em acho que tava no quinto parado, ... para levar duas pessoas do quinto ao nono andar.

Rebeca- Então o deslocamento é do quinto ao nono andar! Quanto... que distância você acha que tem (fala mais para Camila do que para Carmem)

Camila- São quatro andares!

Rebeca- Então... uns 30 metros.

Carmem- É muito!! (Camila concorda)

Rebeca- Uns 10 metros então?

Carmem- Não, 10 metros?

Camila- Muito!

Rebeca- 2 metros!

Carmem- Um!?

Rebeca-Dois!

Camila- É porque aí da 2 metros para cada andar (fala para Carmem)

Rebeca- É, dois! Então, dois metros cada andar? Do nove ao cinco, ... quatro,... oito metros.

Contudo, após encontrarem um valor a celeuma continuou e Carmem pediu que chamassem o professor e indicou o que deveria ser mostrado quando ele chegasse ao grupo.

Carmem- A gente não tá conseguindo entrar num acordo...

Camila- Num acordo com os cálculos!

Rebeca- Então, a gente já sabe o deslocamento! ... a gente já estimou o deslocamento.

Carmem- Eu vou por pelo menos o deslocamento (ao dizer isso pega a folha da mesa da Camila para escrever o que havia dito).

Carmem-Vamos chamar o professor e falar com ele que a gente estipulou a força... (fala com voz baixa)

Rebeca-Ele falou que a gente pode estipular... que a gente não sabe quanto tem!

Carmem e Camila- Quem disse? 
Carmem- E quanto mais ou menos então? É difícil!

Rebeca- Então...

Carmem-Será que a gente pode usar a fórmula?

Camila- Então, é isso que eu não sei!... pergunta pra ele (se refere ao pesquisador).

Carmem- Vamos chamar o professor, vamos chamar ele ali (se refere ao pesquisador) e falar com ele que a gente não conseguiu estipular a força (fala em voz baixa, como quem está cochichando para esconder o que está falando)

Camila propôs que perguntasse ao pesquisador também em voz baixa, como quem não queria ser ouvida. Sua posição no grupo era tal que ficava de costas para a filmadora quase todo o tempo da aula. Vale lembrar que esta aluna no início da aula foi a que mais se mostrou indisposta com o fato de elas serem filmadas e disse que ficaria de costas.

\section{6-O professor chega ao grupo $(\mathbf{0 . 3 1 . 0 8})$}

Quando o professor chegou ao grupo ele se sentou numa cadeira indicando que permaneceria ali com elas por algum tempo. As alunas não reagem inicialmente à sua presença, dando continuidade ao que estavam discutindo que era sobre o valor da força.

Prof- Demorei, mas cheguei!

Carmem- Ah! Que bom!

Rebeca- A força é o que, tração, normal?

Carmem- Não, pelo menos é de tração, né?

Rebeca-Por que vocês não perguntam... (fala baixando a voz)

Camila- Por que não pergunta logo?

Rebeca-Professor, a gente tá com dificuldade, aqui!

Camila- Dificuldade de até levantar o lápis para escrever! (risos)

Com o professor no grupo, Camila se manteve totalmente de costas para filmadora e de frente para o professor. Este, ao ouvir que as alunas estavam com dificuldades antes de responder olhou rapidamente para a filmadora, pois nesse momento o pesquisador estava manuseando-a. Em geral, o aparelho ficava perto do grupo sem que o pesquisador a operasse sempre. Ao relatarem para o professor que estavam com dificuldades, uma esperava que a outra dissesse qual era a dúvida, e quem tomou a iniciativa foi a Rebeca:

Rebeca- A gente não tá conseguindo...

Camila- ... entender... 
Rebeca-... ter uma noção básica do que é o trabalho e a força, a gente tá esbarrando na força.

Camila-Simplesmente a gente não entendeu o primeiro exercício! Pronto, não é mais fácil? Porque a gente não entendeu mesmo!

Rebeca-Não, a gente entendeu, porque, porque a gente calculou, estipulou a força...

Camila- (interrompe a colega) Mas a gente não sabe se tá dando certo o que a gente tá falando... a gente tá indo por uma noção.

Rebeca-Mas é o que está escrito aí!

Camila- Tá, explica professor!

Prof. O que vocês chegaram de conclusão? Mesmo que vocês não acham que seja a conclusão certa. O que vocês descobriram aí?

Quando Rebeca disse que haviam entendido e estipulado se referia ao deslocamento e à força, porque era o que faziam antes de o professor chegar ao grupo. E Camila, ao expressar que o grupo estava indo por uma noção, também se referia ao deslocamento.

$\mathrm{O}$ professor se manteve interagindo com as alunas, fazendo perguntas a fim de conduzí-las a compreensão do problema. A cada pergunta que fazia uma aluna diferente lhe respondia de tal modo que todas participavam desse momento, indicando uma fluidez na comunicação. E quando ninguém lhe respondia, ele então fazia outra pergunta para que elas concluíssem a questão.

À medida que ele procedia dessa forma com as alunas, era possível fazer uma avaliação do quanto e como elas estavam entendendo e aprendendo o conteúdo em questão. Nesse processo, foi possível perceber que o grupo tinha dificuldades ainda sobre a diferenciação entre peso e massa. Então, o professor interveio no sentido de ajudá-las com esse tema, pois era pré-requisito para esse exercício (precisava determinar o peso do elevador):

Prof- Qual o peso do elevador?

Rebeca- Você quer em Newtons?

Prof. Não, quero o peso! ... Qual a diferença entre o peso e massa?

Tem alguma diferença?

Rebeca-Tem!

Camila- Tem (desvia o olhar do professor) Qual é a diferença? (se pergunta em meio a risos)

Rebeca- Ah! Eu sei que massa é quilograma e que Newton... que peso é Newton!

Prof.- Já é um bom começo!

Todas- Aee! (comemoram) 
Prof. -É! Mas o que mais? Isso ainda não é o suficiente ... para saber o que é peso!

Cris- Nossa!?

Regina- Não?

(Silêncio)

Prof.- Qual é a sua massa? (pergunta para Rebeca)

Camila- Quanto você pesa? (também pergunta a colega)

Carmem-Massa é o que ... é o que a gente se pesa, né?

Prof.- É, massa é o que o a gente olha em peso, né?

(risos)

Rebeca- Não sei!

Prof.- Qual a sua massa?

Rebeca- 57 quilogramas!

Prof.- Isso! E o peso?

Camila- Tem que multiplicar por 10 ?

Prof.- (acena que sim com a cabeça)

Camila- Ah! É!

Rebeca- 570?

Prof.- E por que 10? (pergunta a Camila)

Camila- Por causa da gravidade?

Carmem- É!

Camila- É, tá certo!

Prof.- Por causa da aceleração da gravidade da Terra!

Rebeca- Eu peso 570?

Camila- Quando a gente que encontrar o peso, lembra? (fala para Regina)

Regina não ouviu o que Camila lhe disse, pois estava interessada na estética corporal:

Regina- Você pesa mais do que eu Carmem?

Carmem- Não, então vamos para a balança!

Camila- Não, pera ai, voltando ao exercício... lembra quando a gente queria encontrar o peso? A gente fazia peso iguam a massa vezes a gravidade, então vai ficar ... vai ficar seis mil? É seis mil!

Prof.- Seis mil o quê? ( e aponta para Regina)

Camila e Carmem- Newtons

Prof.- Newntons!

Camila- Agora a gente entendeu!

Rebeca não respondeu ao professor e nem comentou a conclusão da colega. Contudo, determinar o peso do exercício não era o objetivo final daquele exercício e por isso o professor lançou mais uma pergunta, a fim de levá-las a compreensão do que se pedia: 
Prof.- Então, quanto tem que ser a tração pelo menos?

Carmem- Pelo menos seis mil!

Camila- Seis mil!

Rebeca-Mas esse valor alto assim, seis mil? Não tem como baixar um pouquinho?

Camila- Não tem como baixar!

Rebeca- Não tem como baixar (parece se conformar)

Prof. - Vocês acharam a força de tração! Uma das informações necessárias para vocês fazerem uma estimativa do trabalho.

Com essa colocação do professor, iniciou-se no grupo um novo ciclo e então Carmem expõe a sua dúvida sobre esse conteúdo.

Carmem- $O$ trabalho é quando eu gasto energia?

Prof.- Aí é outra conversa! O que é trabalho?

Ao dizer isso, o professor se posicionou na cadeira, mudando sua posição para indicar que estava disposto para esse novo ciclo, já que antes disso ele estava mais debruçado sobre a cadeira.

Observa-se dessa forma que o tema do trabalho, que era o conteúdo do exercício que resolviam, foi menos explorado do que o anterior (peso e massa) e a forma de abordá-lo também foi diferenciada. Aqui, o professor fazia as perguntas, mas não esperava as respostas das alunas para deixar que elas chegassem à conclusão, como acontecera com Camila anteriormente. Logo em seguida, com a conclusão feita pelo professor, eles (professor e as alunas) passaram para a discussão da estimativa do deslocamento, que era o tema que as alunas discutiam minutos antes de falarem sobre a força cuja última fala delas foi "não conseguimos chegar a um acordo sobre um valor!".

Quando entraram nesse tema, o professor teve uma atuação semelhante quando tratavam do peso e massa, pois ele fazia perguntas, sem dar as respostas para deixá-las concluir. Além disso, parece-nos que o professor assumia as funções que as alunas deveriam exercer durante a resolução do exercício e realçava aquela que era menos compreendida e, portanto, não exercida. Com essa postura era como se estivesse mostrando as alunas como deveriam proceder com as funções.

Prof.- Vocês sabem o quanto o elevador vai se movimentar, ou não sabem?

Rebeca-Sabemos (...) a gente falou que cada andar tem 2 metros.

Prof. Dois metros! (faz que concorda)

Rebeca- É, vai andar do oito metros! 
Prof.- Você concorda que tem dois metros? (pergunta para Camila, que escrevia durante a fala anterior)

Camila- (silêncio) Desculpa, eu não estava prestando a atenção! (risos)

As suas colegas lhe explicaram o que estava ocorrendo, até que todas se envolveram novamente no processo de discussão e esse ciclo foi encerrado quando o grupo percebeu que não haviam estimado um bom valor para o deslocamento encontrando outro mais satisfatório.

O último tema que o grupo discutiu com o professor nessa sua intervenção foi sobre o ângulo na expressão matemática do trabalho, que também já haviam encontrado dificuldades anteriormente. A forma como o professor conduz o grupo nesse momento é semelhante a como fez quando trataram sobre trabalho e quem concluiu foi ele próprio:

Prof.- Esse ângulo ali na formula é o ângulo entre a força $e$ o deslocamento. Acho que é informação o suficiente já!

Todas- É!

Prof.- Vocês estão fazendo na folha aqui (se refere a folha do grupo)

Camila- Não, não, é que eu to anotando só as informações aqui.

Prof. - Bom, veja o quanto vocês vão agora!

Rebeca- Tá! Obrigada, professor!

\section{7-Após a saída do professor (0.41.38)}

Após a saída do professor, Camila e Carmem escreviam em suas folhas sendo que Carmem tinha a folha do grupo, já que era Anotadora. Regina, que se posicionava de frente para as colegas, inicialmente lhes falou do tempo que restava, apressando as colegas (era sua função como Líder controlar o tempo). Em seguida, ela reclamou que era única que não escrevia nada e, passados alguns instantes, auxiliou as outras duas pesquisando no livro o valor do cosseno de zero.

Surgiu um assunto sobre matemática logo que Regina lhes falou o resultado que ela encontrou. Elas comentavam a dificuldade com essa disciplina e suas notas nas provas e sua evolução ao longo do ano, mas ao chegarem o resultado final do exercício esse assunto logo mudou.

Com o término do exercício, o grupo encontrou uma dúvida em relação à unidade de medida que deveriam usar para o trabalho:

Camila- É Newtons por metro ou metro por Newtons?

Regina- É Newton por metro, fica mais bonito! ... Será que existe isso? 


\section{Camila- Professor!}

Após a chamada de Camila pelo professor, elas ficaram em silêncio enquanto o aguardavam. Regina o chamou mais uma vez, mas percebeu que estava em outro grupo e que não iria até elas naquele momento, então Carmem sugeriu chamar o pesquisador para ajudá-las. Ao propor que ele fosse chamado, elas ficaram constrangidas e começaram a rir e como Regina não sabia o nome dele, Carmem teve de lhe falar, o que a deixou mais envergonhada.

\section{8-Rápida intervenção do pesquisador $(0.31 .08)$}

Assim que o pesquisador chegou, Regina foi a primeira a lhe dirigir a palavra, já que as outras duas estavam tímidas:

Regina- É ... como fica aqui?

Camila- É Newtons por metro ou metro por Newton?

Pesquisador- $O$ quê?

Carmem the mostrou na folha de resolução o que era a dúvida delas, e o pesquisador explicou, tentando conduzi-las a conclusão por si mesmas. Assim foi até que ao apontar no livro para elas, conseguiram a resposta:

Rebeca- Joule?

Pesquisador-Joule!

(comemoração pela resposta)

Camila- Ah! Obrigada! A inteligência das garotas, assim... impressionante!

Quando o pesquisador deixou o grupo elas ainda riram da situação e fizeram alguns comentários, e por fim concluíram o primeiro exercício.

\section{9-O outro problema $(\mathbf{0 . 4 8 . 3 0 )}$}

Rebeca mais uma vez olhou o relógio e apressou as colegas dizendo que o tempo estava acabando e que ainda tinham que fazer os exercícios seguintes. Então, Carmem iniciou a leitura do outro problema e à medida que lia Camila e Rebeca davam risos irônicos devido à dificuldade que teriam em resolvê-lo.

A postura de Rebeca, no entanto, era diferente das outras, por mais que também achasse difícil, pois ela indicava possibilidades de resolução acalmando assim as colegas. Porém, diante de uma dúvida mais geral, o grupo paralisou e Carmem mais uma vez sugeriu que chamassem o pesquisador. Rebeca então lhe respondeu: 
Carmem- Não, espera aí então! O que a gente via falar para ele?

Rebeca- Ah! Já chamei! (risos),,

Camila- A gente que saber o quê??

Rebeca-Vamos tentar sozinhas!

Carmem- Como?

Rebeca- Se a gente errar, apaga e faz de novo!

(Silêncio)

Rebeca- Não vou nem insistir porque vocês não concordam (reclama frustrada)

Rebeca, mesmo não sendo correspondida, insistia que o exercício era simples e que bastava utilizar regra de três e porcentagem. Entretanto, as colegas não lhe deram atenção e na seqüência Camila encontrou no livro algo que poderia ajudá-las chamando os membros do grupo para que ouvissem o que ela estava lendo. Elas passavam por um novo momento de dúvida coletiva e permaneceram assim até o professor retornasse.

\subsection{0-O professor no grupo (0.51.46)}

Assim que o professor chegou ao grupo, Rebeca foi prontamente perguntando se o que ela havia proposto ao grupo era o correto a ser feito. Ao ouvir a reposta do professor confirmando seu pensamento, imediatamente falou com as colegas, gerando um clima mais tenso entre ela e Camila.

Rebeca- Tá vendo, eu estava falando com vocês, mas vocês não me escutam!

Camila- Tá bom! (encerra o assunto com Carmem)... Não que a gente não te escute, só que a gente falou: 'vamos ver outras coisas antes!'

Rebeca- Não me escuta!!

Camila- Ah! (responde irritada) ... Então vai! (fala para Rebeca)

Rebeca- Vai Carmem, faz!

Enquanto as duas dialogavam, o professor somente as observava e Carmem iniciou uma crise de tosse coincidindo com a chegada do professor. Quando Rebeca lhe disse para fazer, ela estava tossindo muito e o grupo (incluindo o professor) silenciou ainda num estado de tensão e Camila que estava ao seu lado tentava lhe acudir. Ainda enquanto Carmem tossia o professor começou a falar:

Prof.- O papel do Líder também é ... (pausa para pensar) se certificar de que o grupo vai fazer as coisas e chamar o professor quando o grupo tiver problema. Então nesse caso quem chamou o professor foi a Rebeca.

Rebeca- É, eu chamo todo mundo! Só eu que chamo! 
Passado a crise de tosse de Carmem, Rebeca perguntou ao professor se elas estavam atrasadas em relação à turma. Este lhe respondeu que se preocupasse com o tempo e não com a turma, ele também as tranqüilizou, indicando que poderiam terminar o exercício depois, desde que a o motivo do atraso não fosse devido à dispersão com conversas sobre outros assuntos. Rebeca então logo disse que o grupo não estava fazendo isso e que a prova de que ela falava a verdade era a filmadora que registrava tudo.

O professor permaneceu no grupo, mas não interagiu como da outra vez, porque a dúvida que lhe fora apresentada era simples e logo foi resolvida. Então, ele se manteve observando-as, Carmem já tinha passado sua crise de tosse e resolvia o exercício com o auxílio de Camila que estava ao seu lado, até que ele perguntou ao grupo sobre a função do Questionador:

Prof.- A Questionadora é a Camila, não é?

Carmem- É!

Prof.- E ela questionou aí com vocês por que 72 é 100\% (se refere aos valores do exercício).

Carmem- (que estava com a folha de resolução e mais próxima ao professor) Questionou por que Joule...

Ao ouvir que Camila questionara o porquê Joule, Rebeca reagiu dizendo que não concordava com que a colega havia feito isso. Segundo Rebeca, ela própria teria questionado o significado dessa unidade e terminou dizendo que ela deveria ser a Questionadora, como já havia dito no início da aula. O professor lhe respondeu que a vez dela chegaria.

O professor, então, assumiu essa função e perguntava cada etapa da resolução do exercício indicando com essa sua postura como deveria ser feito por elas, até que chegaram à conclusão de que estavam resolvendo o exercício de forma errada. Quando perceberam no que consistia o erro, reclamaram um pouco, mas aceitaram recomeçar o exercício, tendo o envolvimento das três. Enquanto elas resolviam novamente o mesmo problema, o professou saiu do grupo sem elas o notassem.

\subsection{1-Após a saída do professor $(0.56 .20)$}

Durante a resolução do problema, Camila e Rebeca eram quem mais se envolviam enquanto que Carmem tinha uma postura mais de executar o que as outras duas falavam. Porém, depois da Anotadora quem mais tinha acesso à folha de resolução 
do grupo era Camila, que estava ao seu lado. Rebeca nem sempre via o que as duas resolviam.

O enquadre do grupo permanecera assim até encontrarem uma nova barreira, que era a dificuldade em operar um cálculo matemático. Elas tentaram algumas vezes e não conseguiam a resposta e ainda se assustavam com o valor que encontravam, por isso achavam que não era o resultado. Então Rebeca se manifestou ao grupo:

Rebeca- Acho que tá muito absurdo esse valor, hein? ... Vamos fazer esse aqui primeiro, porque isso não pode ficar tão grande assim!

Camila- $O$ que é esse aí?

Rebeca-Aquele lá eu falei ... (segue lendo o exercício)

O grupo então aceitou a idéia de Rebeca e passaram a resolver o exercício que ela sugeriu, e assim foram até que se deram conta de que este também era complicado, segundo elas e voltaram para o anterior. Após refazerem as contas, as alunas esbarraram no mesmo problema anterior e a folha de resolução do grupo começou a circular entre elas, para cada uma tentar conferir o resultado.

Em alguns momentos de discussão, parece-nos que Camila assumia a sua função de Questionadora, sobre tudo em relação a Rebeca. Esses momentos de interação entre as duas costumavam ser tensos, como podemos ver a seguir:

Rebeca- Nossa, daqui a pouco vai começar Watt!

Carmem- Aí meu Deus!

Camila- Ah! Mas acho que já tudo aqui (se refere ao tema de potencia)

Rebeca- É nada!

Camila- Claro que é! (não olha para Regina ao falar)

Rebeca- Cadê Watt aqui? ... Nossa, resposta vai ser em Watt, será?

Camila- Acho que sim! ... Peso total é igual a Watt (lê no livro o símbolo P e associa ao peso).

Carmem- Vai gente, o que vamos fazer então?

Carmem não participou das discussões entre as colegas porque estava cumprindo a sua função de Anotadora. Contudo, essa sua postura era recorrente, pois ela sempre estava escrevendo quando Rebeca e Camila discutiam um assunto (com ou sem tensão) e solicitava as colegas para que lhe dissessem o que tinham que fazer.

As alunas tinham por objetivo calcular a potência total, que tinha referência àquele exercício do elevador no qual calcularam o trabalho estimado do elevador ao se deslocar do quinto ao nono andar com duas pessoas dentro. E para o exercício atual, que 
havia dado a resposta certa foi Rebeca, que acabou sofrendo resistências das colegas. Ao encontrar no livro a forma de resolvê-lo, disse ao grupo:

Rebeca-Tem aqui, total... a gente quer saber a total, não é? Olha aqui (pede a atenção), a energia total é igual a útil mais a dissipada! Carmem- $A$ dissipada?

Rebeca- A dissipada... é a forma de energia fornecida pela maquina (...) (segue lendo no livro)

Carmem- A gente faz uma conta para descobrir a total e depois a gente vai para isso.

Rebeca- Então, total é isso aqui, ó! A útil mais a dissipada!

Carmem- Então, vamos descobrir a total e depois a gente faz isso

Rebeca- Então, para descobrir a total a gente tem que fazer isso aqui!

(Silêncio)

Ao término do diálogo com Rebeca, Carmem não mostrava mais disposição para continuar, pois ao insistir com sua idéia pela última vez, não mais olhava para a colega, e já escrevia algo na folha do grupo. Enquanto as duas dialogavam, Camila não interveio em momento algum, pois estava fazendo os cálculos do exercício anterior, o qual tinham abandonado e depois retornado. Passados alguns minutos, Carmem, que tentava resolver como tinha dito a Rebeca, não conseguia e sugeriu mais uma vez chamar o professor.

\subsection{2-O grupo em busca de uma resposta (1.06.48)}

O grupo se configurava em subgrupos em momentos que tentavam resolver o exercício: Carmem e Camila tinham a folha do grupo e não obtinham sucesso, julgando, portanto, ser impossível a sua resolução; Rebeca permanecia tentando encontrar uma solução e para isso manuseava o livro na esperança de encontrar algo que lhe ajudasse. Nesses momentos de subgrupo, o mote do grupo passava a ser a busca por uma resposta a todo custo. E como não conseguiam tão facilmente, Carmem sempre sugeria que pedissem a ajuda ao professor ou ao pesquisador.

Ao encontrar algo que poderia ser útil para a resolução, Rebeca comunicava ao grupo, e conseguia chamar a atenção das colegas para que tentassem junto com ela e assim as três participavam das discussões. O que as animou um pouco mais, foi quando Camila percebeu que um outro grupo estava com dúvidas no mesmo exercício que elas. E a sugestão de resolução vem de fora do grupo, quando elas ouviram como que esse grupo tentava resolver a questão. 


\subsection{3-O professor retorna ao grupo (1.12.16)}

Assim que o professor chegou ao grupo, não houve muitos rodeios como da primeira vez para fazer as perguntas. Logo lhe dirigiram a palavra:

Camila- Professor, num sai!

Rebeca- Professor, tem que achar a aceleração, velocidade, alguma coisa assim nesse exercício? Porque aqui está falando de tempo, de não sei o quê! Tem alguma a coisa ver, não tem?

Camila- A gente estava olhando a folha e não sabe se é mesma que a gente vai usar (aponta a fórmula no livro)

Carmem- A gente tentou calcular a dissipada

Ao ouvir cada uma, o professor pediu para ver o que elas tinham feito e lhes indicou uma solução (regra de três) que Rebeca já tinha sugerido anteriormente e se alegrou ao ouvir a resposta do professor. Em seguida, Camila mostrou o que ela tentou fazer e Carmem reclamou do valor absurdo (segundo elas) que estavam encontrando. $\mathrm{O}$ professor pediu que elas refizessem os cálculos para ajudá-las no processo, dando dicas das operações matemáticas. Ao encontrarem o resultado, o professor permite que o configurem usando a calculadora:

Prof.- Agora você pode fazer na calculadora, para ver se errou alguma coisa (fala para Cris)

Rebeca- Ai, imagina se agente tiver errada... eu... (não completa a frase)

Prof.- Se tiver errada, corrige, faz parte errar também.

Rebeca- Eu sei que faz parte, mas é horrível, é horrível!

Prof. É horrível, mas vocês têm aprender $a, a \ldots$

Rebeca- Nossa em casa eu começo a errar e saio quebrando tudo!

Quando conferem o resultado, encontram algumas diferenças devido ao arredondamento do valor que fizeram na operação anterior. Rebeca era a mais ansiosa para verificar o resultado. Após esse evento, o professor mostrou às alunas outra forma de resolver aquela operação:

Prof.- Me empresta um rascunho! ... Oh! Oh! (arregaça as mangas da sua blusa)

Rebeca-Agora o professor acaba com a gente!

Camila- É acaba com a gente!

Prof.- Não, não, eu não vou fazer a conta!

(risos) 


\subsection{4-O professor ainda no grupo: intervenção presencial (1.22.20)}

Quando o professor terminou de explicar-lhes a outra maneira de fazer aquela operação matemática, ele retomou o assunto sobre errar que havia mencionado anteriormente. A seguir, enquanto as meninas refaziam o exercício, houve um silêncio, o que possibilitou o professor entrar no assunto:

Prof.- Outra coisa: vocês, vocês (pausa para pensar o que ia dizer)

Prof.- Vocês precisam aprender a lidar com erro também, porque ele faz parte do processo pra aprender.

Camila- É que vai e volta, vai e volta!

Prof.- É impossivel aprender sem errar... se você ficar muito preocupada... ele é necessário pra aprender. Se você ficar muito preocupado em não errar, não errar, não errar ... ele faz parte do processo! Você não vai conseguir escapar dele!

Inicialmente quem correspondia ao professor era Camila, pois as outras duas estavam encerrando as atividades ainda referentes àquela operação: Regina terminava de verificar na calculadora e Carmem a escrevia na folha do grupo. Porém, quando o professor a segunda parte da sua fala, quem lhe correspondia era Rebeca, pois esse era um assunto de seu interesse.

Rebeca- O problema não é errar, é que a gente fica lá 40 ou 50 minutos em cima de um exercício e quando vê errou uma vírgula, faltou um zero, aí errou tudo. Nossa! Que nervoso que dá!

Prof.- Faz parte! (fala calmamente)

Nesse momento, Camila interrompeu e perguntou a Rebeca sobre o exercício, para confirmar se o valor encontrado era o que elas estavam procurando ou ainda tinham que fazer outra coisa. O professor em seguida prosseguiu e trouxe um exemplo de um outro aluno da sala (Tim) comentando- ele diminuiu o volume de sua voz enquanto falava- sobre o processo nas provas de Física e comentou sobre uma questão em que ele havia feito tudo correto, mas quando foi calcular a força peso, não multiplicou pela gravidade. Ao concluir, professor disse:

Prof.- Isso faz parte, eu sei que isso faz parte. São fases que a pessoal passa. Primeiro não sabe nada, Depois a gente começa a entender uma coisinha, mas mesmo já é muita.

Carmem e Camila entraram na conversa quando foi falado sobre nota e então cada uma delas comentou a sua evolução ao longo do ano e as três disseram o mesmo: no início tiveram um rendimento melhor e que no bimestre em que estavam $\left(3^{\circ}\right)$ houve uma queda. O professor buscava orientá-las dando exemplo de si mesmo, de como ele 
fazia para estudar, quais eram suas estratégias, etc. E como exemplos mais gerais ele comentava caso de outros alunos de como esses conseguiam aos poucos bons resultados. Quem mais expunha ao professor suas dificuldades para estudar era Rebeca enquanto que as outras comentavam uma com a outra.

Com o passar do tempo, Camila se mostrava mais impaciente com aquele assunto, demonstrando estar mais interessada em resolver o exercício e ao perceber uma brecha na fala do professor logo lhe perguntou algo sobre o exercício:

Camila- Professor, a gente vai ter que fazer essa agora sobre potência máxima?

Prof.- Vai! ... E aí? Agora vocês vão acertar ou errar?

Camila- Vamos ver, né? (risos)

Rebeca- Agora eu vou acertar!

Prof.- Vocês têm que pensar assim. Depende, seu eu já compreendo mesmo, eu vou acertar. Se eu errar é porque falta alguma coisa, e aí vou atrás do que falta.

Camila- É! Que nem eu, se eu já sei explicar os mais difíceis, porque os mais fácies eu já sei fazer em casa, para ver se eu consigo fazer [os mais difíceis]. Porque se eu não for bem na prova, não sei nem o que vai acontecer comigo!

Rebeca- Quer dizer, que é assim, a gente vê uma coisa fácil, e aí a gente fala: 'não é isso, não pode ser!' Porque Física é difícil! Então a gente vê uma coisa muito fácil ou a gente tá entendendo, fala que é difícil, não pode ser, Física é difícil. Aí a gente vai procurar outra coisa, mais complicada ainda!

Prof.- Porque é assim: quando você acha que uma coisa é fácil é porque você entendeu. E quando você acha que a coisa é difícil é porque ainda precisa de umas coisinhas a mais para entender. A partir do momento em que você entender, não via achar aquilo tão difícil mais. Você que dosa o que é fácil e difícil, dependendo do que você já conhece.

Rebeca- Na prova, quando a gente está resolvendo a prova e a gente diz: 'não pode ser isso, tá muito fácil!' Mas às vezes é isso, 'mas por que vou colocar, isso é muito fácil'.

O professor continuou estimulando esta aluna a ter confiança em seus estudos e ainda conversavam sobre assuntos do gênero, até que Camila e Carmem, que estavam mais atentas ao exercício do que o professor, levaram-lhe uma dúvida. A partir daí, as três passaram a resolver juntas a atividade, com poucas intervenções do professor que confirmava quando elas acertavam. Essa configuração permaneceu assim, inclusive após a saída do professor que nem fora notada pelas alunas. 


\subsection{5-Após a saída do professor e momentos finais (1.36.40)}

A configuração anterior se manteve por algum tempo após a saída do professor, mas começou a modificar para uma estrutura tal que era possível observar a formação de subgrupos, como anteriormente: Camila e Carmem estavam com a folha da resolução e interagiam mais entre as elas enquanto Rebeca parecia assumir a função da colega de Questionadora, pois sempre "o que é?" para tudo que as colegas falavam, mesmo o que era discutido entre elas.

Em vários momentos Rebeca expunha alguma idéia que não era nem mesmo ouvida pelo grupo e à medida que a aula se aproximava do término este evento se tornava mais recorrente, evidenciando-se aquela tensão entre Rebeca e Camila. O grupo nessas discussões próximo ao fim da aula estava patinando devido a uma outra dúvida surgida. É possível exemplificar essa situação:

Camila- $F$ mais $T$ é igual ao $P$ (fala para Carmem)

Rebeca- Gente, onde é que está isso que vocês estão falando?

Camila- Como que é? É 5 a força? (responde à Camila)

Camila- Força de 72 Newtons! (se refere a tensão do cabo de elevador)

Rebeca- O que é o T? ( pergunta para Camila)

Camila- É não, não é o T? (fala para Carmem)

Carmem- Ãh!

Camila- É! Tração no cabo...

Rebeca- E o que é T?

Carmem- Mas não é 11000?

Camila- O peso dele é de 11000, Carmem (fala com ênfase)

Rebeca- Pera aí, qual é a força de tração no cabo?

Camila- E aqui tem 72000! A tração no cabo devido à força peso! (continua explicando para Carmem)

Carmem- Tá!?

Rebeca-Mas no outro exercício, qual que é o valor de tração, 600 Newtons?

Camila- Âh? (agora responde Rebeca)

Rebeca- $O$ valor da tração é 600 Newtons?

Camila- É o mesmo! (fala com ênfase)

Carmem- Aonde você está vendo isso?

Camila- A força, Carmem! A força, Carmem!

Carmem- Tá! E depois?

Camila- A potência útil do motor é dada por ... (segue lendo livro)

Rebeca- A gente quer descobrir o peso? 
Carmem- Calma aí, o que é para fazer?

Rebeca- A gente quer descobrir o peso? A gente não quer descobrir a força, a potência?

Quando Rebeca disse isso, as duas colegas olharam para ela, mas continuaram a sua empreitada na qual Camila explicava para Carmem o que deveria ser feito. $\mathrm{Na}$ sequiência os eventos foram semelhantes aos anteriores em que Rebeca parecia ser excluída, não tendo suas perguntas ouvidas. Contudo, houve uma situação em que Rebeca expôs a sua idéia e esta parecia desmontar o esquema de resolução das outras duas, e mais uma vez foi possível perceber uma telê de tensão entre as alunas. $\mathrm{O}$ silêncio gerado, quando Rebeca dizia alguma coisa, passou a ser uma constante no grupo.

Houve um clímax dessa tensão entre Rebeca e Camila quando a primeira lançou uma idéia para resolução do exercício em questão e que parecia fazer sentido. Como reação Camila se mostrava insegura com relação à nova idéia dizendo não ter certeza sobre o que fazer. Rebeca então prosseguiu:

Rebeca- Então vamos fazer isso!

(Silêncio)

Carmem nesse momento olhou para Camila para saber se seguia Rebeca ou não. Camila não olhava para ninguém e manifestava-se resistente. Antes de Rebeca continuar ela olhou para Camila, sem levantar a cabeça, e continuou:

\section{Rebeca- Potência útil...}

Camila- Eu não sei! ... Pergunta para ele, ele falou que era isso! (se refere ao professor)

Rebeca- Oi?

Carmem- Se ele falou que isso, é!

Rebeca inicialmente não entendeu qual era o motivo de resistência de Camila, porque ela não percebera o momento em que ela havia perguntado ao professor sobre a fórmula que deveria ser usada. Quando finalmente entendeu, disse:

Rebeca- Então se ele disse...

Camila-Mas não sei em qual, se é só essa ou em todas (se refere as questões)

Rebeca-Pera aí, a gente tem que ver qual são os dados que a gente tem. O que o exercício está pedindo? A potência? 
Quando Rebeca disse isso, ninguém lhe deu atenção e continuaram discutindo qual fórmula deveria ser usada, uma vez que o professor tinha indicado uma delas. Mais uma vez Rebeca pediu a atenção do grupo:

Rebeca- Gente, rapidinho, eu acho que é essa aqui ó! É tudo junto, potencia útil...

Carmem e Camila não lhe deram atenção e, além disso, enquanto Rebeca falava Camila já estava falando sobre um outro assunto para Carmem que mudava o tom da discussão.

Rebeca- Vocês entenderam o que eu quis dizer?

Carmem e Camila- Não!

Rebeca lhes explicou novamente e quando terminou o grupo ficou em silêncio, que foi quebrado por Camila:

Camila- Não entendo!

Rebeca-Camila, se você acha que não é assim, vamos fazer a outra!

Camila- Não, é ... eu acho que é! É que eu to pensando de onde ele tirou isso aqui (se refere a um dado do exercício)

Rebeca- Isso é o " $n$ ", o nosso rendimento, que agente descobriu no exercício anterior, não é?

Camila- Nossa! ... Meu Deus! (risos irônicos) Rendimento?

Nesse momento o professor passou nos grupos recolhendo as folhas de resolução, não importando como que estavam, elas deveriam ser entregues e continuariam na aula seguinte porque a aula já havia terminado.

Ao ouvirem o professor, o grupo silenciou novamente e as alunas pareciam frustradas com o resultado, que não fora alcançado como esperavam. A folha do grupo que estava com a Camila foi dada por ela mesma a Rebeca para esta deixasse com o professor. Camila foi a primeira a deixar o grupo e sua feição indicava descontentamento; ela saiu dali e foi direto para fora da sala de aula. Em seguida, Rebeca saiu para entregar a folha ao professor.

\subsection{4-Análise da aula 12}

O início do grupo se caracteriza pela presença de alguns emergentes que merecem a nossa a atenção e nos parecem importantes para a nossa hipótese interpretativa sobre este grupo, tanto nessa aula como na seguinte. Dessa forma, aquilo 
que surgiu no grupo nesse período foi: a rejeição do aparelho de filmagem e a relação das alunas com a Física (conteúdos, exercícios, etc.).

O rechaço para com a filmadora ocorreu neste e no grupo 2, no qual se manteve por todas a aulas vídeo-gravadas, conduzindo-nos a pensar que ambos tinham algo que não poderia ser revelado pela câmara: um segredo grupal. No episódio 12.1, Carmem e Camila usam as palavras "desligar" e "não aparecer" que transmitem a idéia de que queriam conservar algo em sigilo. Essas mesmas palavras ainda nos sugerem que havia uma aliança (inconsciente) entre essas duas alunas: as duas se manifestaram contrárias ao aparelho e usaram palavras sinônimas para se expressar. Nos episódios seguintes veremos que as duas formaram um subgrupo para excluir Rebeca que não compactuava com elas.

O segredo que não podia aparecer ao pesquisador, que estaria de longe observando, estava relacionado ao não saber Física. Essa relação com o conteúdo físico emergia com frequiência neste período inicial da formação grupal e podemos sustentar a nossa idéia sobre o segredo considerando que Carmem falava a Camila sobre não saber Física em voz baixa, como quem estava confidenciando algo a sua colega. Ao perguntar quem seria a Líder, alterou o tom de voz, expressando a legitimidade do que ela dizia neste momento. Contudo, o que era então sigilo ficava cada vez mais explícito à medida que adentravam na atividade com os outros comentários de Carmem e também de Rebeca, que se disse "burrinha" e que sempre ficava nervosa nas vezes em que não conseguia resolver um exercício ou quando errava após longo tempo de resolução.

Podemos entender melhor a relação com a Física quando buscamos uma visão geral dessas alunas na classe, que segundo os relatos do professor bem como algumas outras filmagens que focalizam toda a classe, nos indicam que elas quase nunca participavam das aulas (que em geral eram expositivas) e que suas notas nas avaliações não eram muito altas. Torna-se visível também, quando as alunas interagiam com o professor no episódio 12.6 em que algumas dificuldades emergiram devidas à falta de domínio do conteúdo, como foi a questão da relação peso e massa.

Contudo, a reação de repudia para com a filmadora somente ocorreu nesta aula. Na seguinte, a 16, o grupo só não reagiu como se mostrou mais disposto, sobre tudo, quando o pesquisador solicitou que elas testassem o microfone e todas o fizeram em 
meio a brincadeiras e risos. Devemos lembrar que entre as aulas 12 e 16 houve outras em que o domínio do conteúdo pôde ser aprimorado.

No episódio 12.2, as alunas iniciaram a atividade, no entanto, não entendiam o que pedia o enunciado do exercício por causa disto, as conseqüências foram circulação da folha do grupo por cada aluna, as reclamações de Carmem e as auto-declarações de incapacidades. Esse momento é expressivo e importante, porque revela a passagem do grupo pela pré-tarefa em que operavam movidas pelas ansiedades de básica de medo e de ataque. O grupo passava por um posição esquizoparanóide, "em que o objeto de conhecimento é vivenciado como perigoso e é adotada uma atitude de desconfiança ou hostilidade ou, então, há uma reação direta com a ansiedade correspondente." (BLEGER, 2001, p. 86).

Em seguida, surgiu no grupo um sistema de comunicação divergente quando Camila pediu que as colegas parassem de falar e resolvessem o exercício. Ela neste momento assumiu o papel de porta-voz porque trouxe para o nível do explícito aquele estado de ansiedade que o grupo vivenciava. Podemos inferir que o sentido de "param de falar e resolvem" era uma forma das alunas não saírem daquela situação, ou seja, parar de falar e resolver mantinha o grupo no "como se" estivessem realizando a tarefa explícita.

Acreditamos que as situações geradas no grupo são frutos da forma como as alunas se relacionam com a disciplina e a partir dessa relação do grupo com a Física buscamos compreender a sua relação com o professor de Física, que a nosso ver é de dependência. A nossa hipótese é que o professor se tornou depositário do grupo cujo conteúdo depositado era o "não saber Física" e que nesse evento se funda o vínculo do grupo com professor, tendo como porta-voz dessa vinculação Carmem que sempre sugeria ao grupo de chamar o professor para explicá-las nos momentos de dúvida.

Encontramos uma referência em Pichon-Rivière (1994) que ilumina a nossa idéia suscitada no parágrafo anterior: "quando deposita sobre outro sujeito mediante o mecanismo de (...) projeção, um determinado objeto interno, estabelece com ele um vínculo fictício, como o é, por exemplo, o vínculo transferencial” (p. 51). Isto é, o não saber Física é o vinculo transferencial deslocado do grupo para o professor.

Por outro lado, o vínculo que o grupo teria criado com o pesquisador é diferente do professor, pois o primeiro foi quem introduziu a filmadora no grupo, tornando-se 
aquele revelaria os seus segredos, enquanto que o outro era quem supria a demanda das alunas de não saber Física. Essa vinculação com o pesquisador pode explicar o motivo dos risos envergonhados das alunas quando ele esteve no grupo e a timidez de Carmem sempre quando ela ou Rebeca sugeria que o chamasse. Mas por que elas insistiam em chamar o pesquisador dado que o descrevemos acima ocorria no grupo? Não seria contraditório com idéia anterior?

Respondemos que não! Não nos parece uma contradição, pois aquele vínculo transferencial também era deslocado para o pesquisador uma vez que ele fora apresentado à turma com alguém que poderia ajudá-los tanto com a resolução dos exercícios quanto no uso das funções. Essas duas imagens do pesquisador, que ficaria de longe a observar o grupo e o comparsa do professor, por ora se sobre punham e provocam essa dualidade no grupo $1 .{ }^{21}$

O episódio 12.4 foi marcado pela tentativa das alunas de resolverem o exercício gerando momentos de silêncio ou trocas de informações entre elas cuja rede de comunicação era difusa. Contudo, percebemos que ocorria com muita freqüência um rechaço do grupo para com Rebeca, pois nas vezes em que se dirigia às colegas para alguma proposição, comentário ou elaboração de perguntas não era sempre correspondida, como podemos observar nas falas que deste episódio.

Entendemos que o motivo dessa repulsão era devido a uma tentativa dela romper com aquele vínculo transferencial com professor em quem fora depositado a demanda de não saber Física: as colocações de Rebeca pareciam romper com essa regra gerada no grupo. Quando tentou estimular uma discussão no grupo sobre o que era trabalho ela perguntou as colegas- “o que é trabalho para vocês?"- e não obteve resposta. Em seguida manifestou a sua opinião a cerca do que tinha lido sobre o mesmo assunto, sem que ninguém se interessasse; obteve alguma resposta após uma terceira tentativa, quando Carmem lhe correspondeu. À medida que esta interagia com a Rebeca demonstrava suas dificuldades com o conteúdo, como foi o caso em que não sabia distinguir a massa da força.

Rebeca demonstrava que tinha uma relação com a Física diferenciada das demais, e, portanto, algumas vezes ela tinha informações importantes para a resolução

\footnotetext{
${ }^{21}$ Nos outros grupos o fato do pesquisador ser o comparsa do professor tinha significados diferentes para cada um. Por exemplo, para o grupo 2 ele representava uma ameaça, pois revelaria que fingiam que faziam os exercícios. Para o grupo 3, ele era visto como professor, porque era solicitado em vários momentos e ao chamá-lo, algumas vezes, externavam quando diziam: "professor, pode vir aqui!"
} 
do exercício. Porém, isso não poderia ser tolerado pelo grupo, pois era somente o professor, que na visão delas, quem deveria saber Física. Logo, aceitar o que Rebeca trazia para o grupo era romper com o professor. O relacionamento de Carmem e Camila com a colega fica mais evidente nos momentos finais da aula, quando vemos explicitamente um boicote ao que Rebeca tentava colocar no grupo.

A dinâmica do grupo se manteve assim, o que as levou a reviver aquele posição esquizoparanóide: estimar o valor do trabalho se tornou o objeto de conhecimento hostil e fonte de ansiedades no grupo. As falas desconexas umas das outras indicam a experiência que o grupo vivenciava, pois as três repetiam o que já havia sido falado por alguém. Essa repetição é uma atitude semelhante a da circulação da folha do grupo, pois com isto era "como se" estivessem resolvendo a tarefa.

Como estimar o trabalho tornara-se perigoso para grupo (posição esquizoparanóide), as alunas vivenciaram uma aversão ao objeto de conhecimento ao se distanciarem dele, fugindo-se ao contato ou à aproximação do mesmo. Segundo Bleger (2001), essa atitude é típica quando o grupo vivencia um momento fóbico. Desse modo, por não suportarem tal situação, deslocaram o problema e passaram a estimar o valor do deslocamento sem que tivessem resolvido o outro.

Nessa nova situação, a configuração do grupo se transformou no sistema de comunicação difuso, o que implicou na entrada de Rebeca no grupo novamente, ou seja, suas colocações eram aceitas pelas outras alunas, pois não se opunham às regras que haviam sido estabelecidas. Além do que, tratar sobre o deslocamento lhes parecia mais fácil do que sobre trabalho.

É importante perceber que depois desse momento de interações (vide falas) o grupo chegou a uma conclusão, nos indicando assim que parte da tarefa explicita fora resolvida sem mesmo que o professor viesse lhes ajudar. Podemos dizer que inicialmente, Rebeca assumiu o papel de sabotadora da tarefa, pois foi ela quem propôs a mudança de exercício, por não conseguir resolvê-lo e tão pouco manter um nível de ansiedade ótimo. Entretanto, o grupo aceitou a sua proposta, e ela passou a atuar como líder progressivo, porque ajudava o grupo a superar aqueles momentos de maior ansiedade fazendo proposições e traçando estratégias para o grupo "transformar a árvore em canoa". Esse papel teve a aceitação das demais alunas porque foi Rebeca quem 
propôs que deixassem de resolver o primeiro problema, pois aquele lhes parecia impossível e, por conseguinte não seria possível controlar a ansiedade do grupo.

Um dos motivos para que o grupo tenha chegado a uma conclusão é que, o tema que tratavam era mais próximo de seus cotidianos e, portanto lhes parecia menos abstrato. É nesse sentido também, que acreditamos que Camila disse "a gente tá indo por uma noção" porque nesse assunto, elas podiam conduzir o exercício por uma “noção", quase no sentido de uma intuição. E ainda, Rebeca assumiu aquele papel de líder, pois não precisava perguntar ao grupo “o que é deslocamento?”, como o fizera com outro tema, quando ela colocava a questão, "O que é trabalho para vocês?", corroborando para o aumento de ansiedade, uma vez que estimar o valor do trabalho havia se tornado hostil ao grupo.

Contudo, a obtenção de um resultado sem a ajuda do professor significava uma emancipação do grupo, a qual não foi aceita. Carmem, como porta-voz da dependência do professor logo disse ao grupo: "A gente não tá conseguindo entrar num acordo" e Camila, com quem compactuava, reforçou a reclamação da Carmem. Mas como não haviam chegado a um acordo, se já tinham um valor estimado para o deslocamento? Parece que Rebeca se fez essa mesma indagação e, sendo categórica, disse que o grupo tinha conseguido: "Então, a gente (...) estimou o deslocamento".

Parece-nos então, que foi nesse momento que o grupo, ou o subgrupo Carmem e Camila, explicitou a sua relação de dependência para com o professor, porque diante da fala da Rebeca afirmando que elas tinham chegado num acordo, Carmem imediatamente propôs que o professor fosse chamado. Ainda assim, Rebeca insistiu que o resultado era lícito, pois o próprio professor havia pedido que fizesse tal como elas fizeram e surpresas, as outras duas perguntam: "Quem disse?"

Ao perguntarem a Rebeca "quem disse" que podia fazer aquilo, era como se elas dissessem: "Nós estamos fazendo o que o professor nos pediu, isto é muito difícil e, portanto, não podemos resolver sem ajuda dele. Se conseguimos é porque não é para ser assim!" Então, Rebeca não foi mais ouvida pelas colegas.

Chamar o pesquisador passou a ser uma das possibilidades para resolver aquele problema delas, que passou a ser visto nesse momento como o comparsa do professor, já que este indicava que demoraria muito tempo. É interessante notar que as duas alunas falaram em voz baixa, como um cochicho uma para outra, ao sugerirem que pesquisador 
fosse ajudá-las, o que corrobora a nossa hipótese de que o pesquisador é o mesmo tempo quem fica de longe as observando, tentando extrair o seu segredo e o ajudante do professor em sala (vide também episódio 12.8-9)

Quando o professor, finalmente, chegou ao grupo disse, "demorei, mas cheguei!" sendo correspondido somente por Carmem enquanto que as outras alunas continuaram discutindo entre si o assunto anterior. Esse evento pode vir a confirmar a nossa hipótese de que Carmem era a porta-voz da dependência que o (sub) grupo tinha em relação ao professor.

Nas falas seguintes, Rebeca insistiu com suas colegas para que elas externassem ao professor as dúvidas, o que pode nos indicar que esta aluna não compactuava com as demais a dependência em relação ao professor e sua pergunta, "por que não perguntam vocês?", pode então significar, "por que não perguntam já que eram vocês quem o queriam no grupo?". Vale lembrar que Rebeca em alguns momentos antes havia sido rechaçada pelas alunas quando ela tentava resolver o exercício propondo algumas soluções para o mesmo.

Mesmo assim, foi Rebeca quem fez a primeira pergunta e ao explicitar a dúvida trouxe o tema da primeira dificuldade delas, o qual não fora solucionado. Porém, Camila revelou nesse momento ao professor o não saber Física que o grupo possuía. Torna-se mais claro então que o professor se tornara o depositário do grupo cuja demanda era sua insuficiência com a Física, logo com os exercícios e atividades dessa disciplina.

Parece-nos que Rebeca e Camila representavam lideranças antagônicas dentro do grupo, pois a primeira insistia que o grupo não estava com dificuldades de entender o exercício e haviam feito como o professor havia solicitado (estimando o valor do deslocamento), enquanto que Camila era enfática ao dizer que não compreendiam e nem mesmo deixava a colega falar. Os papéis de uma e outra, respectivamente, dá-nos indícios de ser sabotador e líder.

Rebeca era vista como sabotadora do subgrupo Camila-Carmem, porque demonstrava romper com aquela dependência. Já Camila, assumia o papel de líder (do subgrupo) por tentar zelar por aquele pacto (implícito) assumido por estas duas alunas de que o professor era quem poderia ajudá-las a lidar com não saber Física. Podemos ainda dizer, que essa liderança era autocrática, pois ela interrompeu a colega para dizer 
que não era aquilo que Rebeca falava e por fim, encerrou a sua comunicação de forma abrupta, sem dar margem para uma contra-resposta ao falar: "Tá, explica professor!".

A partir de uma outra perspectiva desse evento que marcou a chegada do professor, é possível corroborar a nossa idéia sobre a abstração necessária para cada tema: quando Camila disse que o grupo resolvia por uma "noção" o item para a estimativa do valor do deslocamento, revelava sua dificuldade com o tópico sobre trabalho que não se podia ir por uma "noção", motivo pelo qual o teriam abandonado em prol do deslocamento.

Caracterizamos como sendo uma intervenção presencial a que ocorreu no episódio 12.6, pois a partir do momento em que o professor iniciou sua fala às alunas, o fez de tal forma que perturbou aquela rede de comunicação e conseguiu trazer todas as alunas para a discussão. Ao proceder assim, foi possível identificar e abordar algumas dificuldades em relação ao tema, o que significa dizer que o professor aceitou aquele depósito do não saber Física e trabalhou temas que nem mesmo estavam diretamente envolvidos com a resolução do exercício, como na questão peso e massa.

Podemos ainda verificar que a intervenção do professor seguia ciclos que ele buscava fechar a partir das conclusões feitas pelas alunas. Quando ele abordava o tema peso e massa procedia dessa forma e quem chegou a uma conclusão foi Camila, ao fazer conexões associativas sobre o assunto. Em outras palavras, o grupo que atuava sob as ansiedades básicas de medo e ataque (medo de perder a dependência do professor e ataque de Rebeca contra essa dependência) superou a fase esquizoparanóide e entrou num posição depressiva, pois com o auxilio do professor, "os diferentes aspectos do objeto de conhecimento foram introjetados, procedendo-se, ou pelo menos tentando proceder, à sua elaboração" (BLEGER, 2001, p. 87).

Essa atitude do grupo ocorria em vários outros momentos, como mostram os episódios 12.12-13 e 12.14-15 quando o professor atuava de forma presencial tratando de outros temas fora do conteúdo a fim de ajudar o grupo a superar a tarefa implícita, $a$ qual podemos dizer que era o medo de tentar resolver o exercício, errar e perder o apoio do professor.

A passagem de um momento ao outro implica a entrada do grupo num processo de pensar sobre o problema cuja conseqüência é equivalente ao abandono de um marco 
de segurança e ver-se lançado numa corrente de possibilidades (BLEGER, 2001). Essa passagem foi auxiliada por aquela intervenção presencial do professor, dado que:

"Para poder pensar é preciso haver chegado a um nível no qual seja possível admitir e tolerar certo volume de ansiedade, provocada pelo aparecimento da espiral, com a conseqüente abertura de possibilidades e perda de estereotipias, ou seja, de controles seguros e fixos" (ibid, p. 74)

Camila então concluiu esse ciclo dizendo: “agora a gente entendeu!". Se antes ela tinha se tornado porta-voz do posição esquizoparanóide do grupo ao dizer, "a gente não entendeu mesmo!", agora se tornara porta-voz do posição depressiva, indicando que o objeto de conhecimento não era mais hostil. Contudo, não podemos negligenciar o fato de que, quem havia ou não entendido foi Camila, mas entendemos que o papel assumido se constitui como uma conjugação entre a sua verticalidade e a horizontalidade produzida no grupo. Ainda nas palavras de Pichon-Rivière (2005), temos:

"As relações intra-subjetivas, ou estruturas vinculares internalizadas, articuladas num mundo interno, condicionarão as características da aprendizagem da realidade. (...) $\mathrm{O}$ mundo interno defini-se como um sistema, no qual interagem relações e objetos, numa mútua realimentação. Em síntese, a inter-relação intra-sistêmica é permanente, enquanto se mantém a interação com o meio." (p. 6; grifo nosso).

O ciclo seguinte tratava sobre trabalho, iniciado por Carmem perguntando o seu significado ao professor. A sua resposta pode corroborar a idéia que já lançamos anteriormente: trata-se de outra conversa porque esse tema não é tão simples quanto o primeiro. Verificamos a partir daí, uma mudança na forma do professor atuar no grupo sendo ele mesmo quem concluiu o tema. Essa mesma postura o professor manteve quando ele explicou sobre o cosseno do ângulo que compõe a expressão matemática do trabalho.

Podemos inferir essa sua fala -“aí é outra conversa!”- como um indicativo de que o professor assumira a ansiedade o grupo de enfrentar um novo ciclo. Era como se ele percebesse que as alunas poderiam não entender tão facilmente quanto o outro tema, e já que elas haviam saltado de um momento ao outro, ao introduzi-las em um outro processo de pensar estava incluído o temor de passar por novas ansiedades e confusões e ficar encerrado nelas sem poder sair (BLEGER, 2001). Parece-nos, então, que ele 
assumiu o papel de porta-voz da ansiedade do grupo por achar que não se conseguiriam suportar a passagem de um momento para outro (como antes) ao introduzir o grupo a outra conversa.

O professor tornava-se nesse momento membro do grupo, tanto no que diz respeito à assunção de papéis como no exercício das funções. Notamos mais explicitamente esta quando, já quase no fim de sua intervenção, ele assumiu a função de Questionador, para averiguar se todas concordavam com o valor estimado do deslocamento. Entendemos, assim, que essa foi a maneira que buscou para explicar-lhes como as alunas deveriam proceder, dado que era a primeira aula que atuavam segundo aquelas funções.

O professor encerrou sua participação com uma intervenção institucional quando perguntou sobre a folha do grupo e como estavam fazendo, o que no fundo significa perguntar sobre a função do Anotador. Além disso, as suas duas falas finais- "acho que é informação o suficiente já" e "veja o quanto vocês vão agora!"- indicam, respectivamente, que ele aceitou o que lhe fora depositado pelo grupo e autorizou a sua autonomia.

No episódio 12.10, após a passagem do pesquisador pelo grupo, elas iniciaram outro problema e sua reação foi de crer ser impossível a resolução. Nesse momento é interessante perceber a postura de Rebeca que inicialmente entrou em ressonância com a histeria do grupo, mas logo em seguida buscou soluções para tentar resolver, assumindo mais uma vez o papel de líder.

As alunas novamente não aceitaram a liderança de Rebeca e assumiram que o professor era quem deveria auxiliá-las a resolver sua dúvida, tendo desta vez, Camila como porta-voz. Aquela contraposição antagônica dos papéis de Rebeca e Camila foi transferida para a relação da primeira com o professor, a que apareceu mais explicitamente nesse evento: o grupo não podia tentar sozinho, pois isso significava uma emancipação da dependência do professor, ainda que ele tenha autorizado a proceder assim. O silêncio gerado no grupo e a fala final de Rebeca revelam essa postura do grupo diante dela (sabotadora) e do professor (líder).

Diante de uma nova intervenção do professor (episódio 12.11), Rebeca foi quem primeiro lhe dirigiu a palavra, pois seu interesse era mostrar ao grupo que sua proposta estava correta e que ademais, podiam resolver a tarefa sem o auxilio do professor. Após 
a confirmação positiva do professor, Rebeca explicitou o que ocorria no grupo, ao denunciar que ela não era escutada pelas colegas, aumentando o clima de tensão entre ela e Camila. Essa tensão entre as duas alunas passou a ser a tarefa implícita que o grupo tinha que resolver a qual obstruía a sua rede de comunicação.

A atuação do professor nesse episódio parece que reforçou os papéis antagônicos entre aquelas duas alunas, pois ele perguntou quem estava na função de Líder dando instruções de como deveria proceder tendo feito o mesmo para função de Questionador. Isso de fato reforçou a disputa de Rebeca e Camila dentro do grupo, dizendo que a primeira procedia de forma correta enquanto que a outra deveria fazer como ele a indicara.

Nos eventos do episódio 12.16, o grupo deixou mais claro o conflito que vivenciava: Rebeca de um lado demonstrava conhecimento sobre o assunto e tentava puxar o grupo para a resolução do exercício e Camila e Carmem do outro, mantendo-se fiel ao que "ele disse", mesmo que isto lhes parecesse incoerente. Rebeca fora rechaçada pelas colegas, porque representava uma ameaça à estabilidade do grupo que era justamente manter-se dependente do professor. As suas propostas ao grupo forçariam as alunas a entrarem num processo de pensar, o que poderia gerar maiores ansiedades e confusões, como já foi apontado anteriormente.

A luta do grupo era entre a tentativa de sair e manter-se no "como se" resolvessem a tarefa. De um lado Rebeca que buscava a mudança, e que inclusive recebeu o respaldo do professor, pois como Líder do grupo deveria chamá-lo quando que precisassem (12.11). Do outro, Camila e Carmem que não queriam aceitar o fato de poderiam seguir adiante, mesmo com tudo o que o professor lhes dissera durante a conversa com elas (12.6).

Por fim, vemos que o grupo encerrou a aula com a sua tarefa implícita não resolvida, e em clima de tensão e frustração das alunas pelo cumprimento da tarefa explicita, que necessitava da outra. Rebeca representava a mudança enquanto Camila representava a não mudança, pois manter-se na posição esquizoparanóide, em que o conhecimento da Física era hostil, era o que manteria o grupo ligado ao professor. $\mathrm{O}$ grupo como um todo não experimentou um salto qualitativo, permanecendo na prétarefa. 
CAPÍTULO 5 


\section{5-ANÁLISE DAS AULAS DO GRUPO 2}

\section{1-O grupo do Gomes: a resistência}

O grupo era composto por quatro alunos, cujos nomes fictícios são: Leandro, Tim, Gomes e Alan, sendo o único que permaneceu sem que saísse ou entrasse alguém. Para a análise do seu processo escolhemos três aulas, 10, 14 e 17, todas no segundo semestre. Na primeira aula, no entanto, as funções não haviam sido outorgadas aos alunos.

$\mathrm{Na}$ aula 10, o início das atividades de grupo foi marcado pelo destaque que o professor deu ao Gomes quando se referiu aos alunos como o "grupo do Gomes". É bem verdade que houve uma tentativa se retratar com a fala seguinte- "não que o grupo seja do Gomes"-que nos pareceu frustrada. Com este evento, percebemos que se torna importante pensar qual o significado dessa fala tanto do ponto de vista do professor quanto do grupo e qual a sua consequiência para o desenvolvimento do processo grupal.

Gomes é um aluno que tinha notas boas em Física ${ }^{22}$ e facilidade para lidar com esta disciplina. Na turma era reconhecido como o "sabichão" e em geral era a ele que os seus colegas recorriam para pedir ajuda com alguns exercícios. É bem provável que seu gosto tenha sido influência de seu pai que era professor de Física nessa mesma escola. Sua fama de "sabichão" também pode ser observada entre os alunos "do seu grupo", já que durante a realização das atividades os colegas o viam como aquele que poderia ajudá-los. Por outro lado, Gomes exercia uma liderança autocrática dentro do grupo, pois em algumas atividades era ele quem as fazia, sem ajuda dos colegas, ou então, dizia o que deveria ser feito a um dos seus colegas que estivesse na função de Anotador ou ainda ignorava os pedidos de ajuda de alguns membros de grupo (vide aulas 14 e 17).

O professor já havia observado algumas dessas posturas de Gomes ainda no primeiro semestre, quando ele assistia à fita de uma das aulas. A solução que ele buscou foi a inserção das funções somente neste grupo para forçar a rotatividade dos papéis, ou seja, o professor esperava que quando um outro aluno assumisse a função de Líder, por exemplo, teria um efeito de "anular" a forte influência de Gomes. Porém, essa medida não obteve sucesso, e ainda causou um desconforto aos alunos, sobretudo ao Gomes,

\footnotetext{
${ }^{22}$ Gomes entrou para o curso de Física da USP em 2007.
} 
quando o uso das funções foi outorgado a todos os grupos da classe, em meados do segundo semestre letivo daquele ano (vide aula 14).

É importante salientarmos ainda que, Gomes era filho dos diretores, que são também os donos da escola. O seu pai além de professor de Física era também um dos donos. Mesmo assim, explicitamente, Gomes não deixava transparecer isso e não aparentava ter suas posturas baseadas em pensamentos do tipo "eu sou o filho do diretor!" E ademais, tinha a simpatia dos colegas de turma e de alguns de outras classes. Considerando isso, a sua figura passa a ser importante na análise do grupo 2 , tanto é que o professor o convocou como "o grupo do Gomes".

\section{2-Aula 10 em episódios (26/08/2004)}

Tal como procedemos com a análise da aula 12 do grupo 1, utilizamos a descrição dividindo as aulas 10, 14 e 17 em episódios cujas marcações se referem ao número da aula que ser refere a uma ordem cronológica da mesma. Acrescentamos junto ao título dos episódios uma marcação de horas, minutos, segundos, nesta ordem, a fim de oferecer uma noção temporal dos eventos.

\section{$10.1^{23}$-Momentos Iniciais}

O conteúdo sobre o qual os alunos discutiam nesta aula era sobre Mecânica Newtoniana, com foco nos diagramas de força no plano inclinado. Os alunos tinham que resolver os exercícios usando a decomposição de vetores através de noções básicas das relações trigonométricas de seno e cosseno.

A atividade em grupos foi iniciada logo após a aula expositiva. Enquanto a câmara ia sendo posicionada, Gomes se levantou para ajudar o professor a arrumar as cadeiras onde os alunos deste grupo se sentariam. Contudo, os outros componentes do grupo se manifestaram contrários quando descobriram que eles seriam os filmados e quem se demonstrou mais insatisfeito foi Tim, ainda que seus comentários parecessem ser em tom de brincadeira.

O professor então convocou este grupo para que se formasse no local indicado:

Prof-Oh! O grupo do Gomes!

\footnotetext{
${ }^{23}$ É válida a mesma regra usada nos episódios das aulas dos outros dois grupos.
} 
Quando ele disse isso, as meninas do outro grupo comemoram, pois elas não seriam filmadas. Em paralelo, quando foi dito "o grupo do Gomes", surgiu um pequeno comentário entre os alunos e então o professor tentou se retratar dizendo:

Prof- Não que grupo seja do Gomes!!!

Nesse momento inicial, os outros alunos não se prontificaram na organização das cadeiras para se juntaram nos grupos, sendo necessária uma outra convocação do professor para tal finalidade. Entretanto, foram os alunos do grupo 3 que tomaram a iniciativa, já que o grupo 1 estava sob os comandos do professor para que se sentasse em uma posição tal que ficasse no campo de visão da filmadora. O objetivo dessa localização do grupo 1 era permitir que a filmadora registrasse dois grupos, embora tendo o som de apenas um deles: o do grupo 2.

\section{2-Grupo 2 já formado para a atividade (0.04.04)}

Temos a partir de agora o grupo já formado para a realização da atividade daquele dia. $\mathrm{O}$ assunto que eles estavam discutindo, no entanto, nada tinha a ver com os exercícios propostos pelo professor: contavam piadas e falavam sobre jogos de baralhos. O mais animado com esse evento era Tim, que tendo a companhia de Leandro e Alan. Já Gomes, manuseava o seu livro para se localizar em relação ao exercício e se mostrava mais preocupado com a filmadora do que os demais, pois com freqüência ele olhava em direção à câmara. Em meio à conversação dos colegas, Gomes então falou ao grupo:

Gomes- Vamos logo que o professor tá pegando nós... câmera de um lado, microfone do outro...

A preocupação de Gomes com o aparato de pesquisa também se deu no cuidado com o microfone, pois ele advertia algumas vezes Leandro para que ficasse atento ao instrumento. Gomes também advertia o colega para que ele iniciasse a atividade e que ficasse mais atento no que o grupo ia fazer. Os outros alunos ainda estavam envolvidos naqueles assuntos.

\section{3-Grupo na resolução da atividade $(0.05 .29)$}

Os alunos iniciaram a resolução da atividade a partir do momento em que Tim começou a leitura do enunciado de um exercício que compunha a tarefa e, aos poucos, foram trocando a conversa pela resolução do exercício. Porém, a leitura de Tim foi superada pela de Gomes que também leu em voz alta o mesmo exercício. 
Quando terminaram a leitura o primeiro que se manifestou foi Alan:

Alan- É fácil!...

Gomes- Faz então!

Alan- Eu faço o cosseno e você o seno... eu faço o cosseno e vocês calculam!

Tim- Vou desenhar para fazer tudo certinho!

Ao se dirigir ao grupo pela primeira vez nesta aula, Alan fez uma divisão do que cada um deveria fazer. No entanto, na divisão não há uma menção ao Leandro, nem explícita, nem implicitamente, pois quando Alan falou não olhou em direção a ele, mas somente para Gomes e para Tim. O resultado foi a entrada do grupo na resolução da atividade, permanecendo cada um fazendo a sua parte, com poucas interações. Leandro, mesmo não recebendo uma "designação", se envolveu na resolução do exercício em questão.

\section{4- Primeira passagem do professor chega pelo grupo $(0.06 .34)$}

Ao se aproximar do grupo, o professor percebeu que os alunos estavam cada um fazendo uma parte do exercício, conforme Alan tinha sugerido. Contudo, eles estavam com uma atenção maior para o desenho que Tim se propusera a fazer. $\mathrm{O}$ primeiro comentário que surgiu ao professor foi de Gomes (0.06.47) e nada teve a ver com o tema do exercício:

Gomes- Tu tá de olho em nós, heim professor! Câmera de um lado, microfone do outro... fazer exercícios! (neste momento fala voltandose para o seu caderno)

Leandro- Big Dumont Brasil! Big Dumont Brasil! (faz um comentário de brincadeira, usando o nome do colégio)

Então o professor saiu do grupo (0.07.15) não falando nada com os alunos. E ao sair, os alunos se encontravam de tal forma que: Tim estava fazendo o que se propôsdesenhando (o plano inclinado); Alan o ajudava; Gomes fazia a sua parte sozinho e Leandro somente observava a todos eles. Ele ainda tentou uma conversa paralela com Tim, que não lhe deu atenção, pois neste momento estava envolvido com a resolução do exercício.

\section{5-Grupo em discussão após a saída do professor $(0.09 .00)$}

Os alunos se envolveram em uma discussão que estava relacionada com o cálculo do valor do seno do ângulo dado no exercício. Gomes então se prontificou a fazer o calculo enquanto Tim insistiu em utilizar a calculadora. Entretanto, Gomes é 
enfático em resolver e, pegando a folha da resolução que estava com Tim, fez o cálculo à sua maneira. Alan nesse momento teve uma participação periférica, enquanto Leandro apenas observava tudo, não se envolvendo no processo.

Ao perceber que todos faziam algo, Leandro tentou interagir com os demais lhes perguntando sobre um dos valores que estava em questão naquele momento:

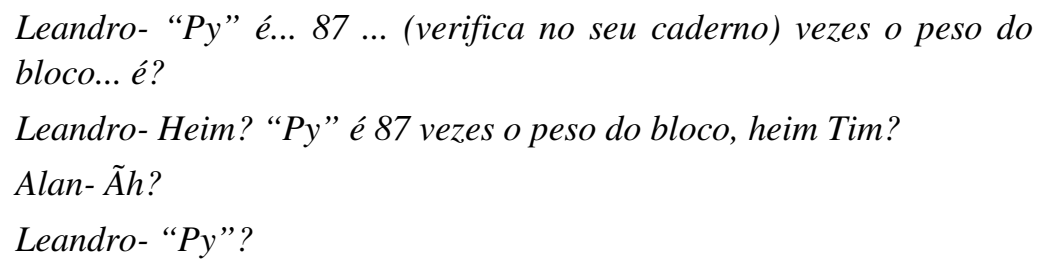

Quando ele falou pela primeira vez ninguém lhe deu atenção, então Leandro insistiu mais uma vez e não obteve reposta; por fim, quando já ia desistindo, Alan lhe respondeu, mas não estabeleceu um diálogo com ele. Após esse evento, Leandro permaneceu quieto novamente, observando os demais. A conclusão deste episódio se deu quando Tim teve uma dúvida sobre o que ele fez estava certo ou não e então ele chamou o professor para conferir.

\section{6-Professor novamente no grupo $(\mathbf{0 . 1 0 . 1 0})$}

Quando o professor se aproximou do grupo, Tim logo lhe pediu para conferir sua resposta, mas o professor não lhe respondeu prontamente; antes, fez uma cobrança ao grupo por intermédio de Tim:

Tim- Professor, vê se eu fiz certo aqui?

Prof- Fez sozinho? O grupo fez junto? Cada um tá fazendo individual aí?

Gomes- Tá pensando aê... cada um na sua!

Tim- Não, não, tava pensando cada um, mas se algum errar então a gente corrige... (responde ao professor tentando dar uma desculpa).

Tim- Então, tá certo? (pergunta logo em seguida ao que tinha dito, mostrando-se interessado somente na resposta do professor).

Então, o professor respondeu inicialmente ao Tim, mas em seguida se voltou para os outros alunos:

Prof- Tá quase! (responde ao Tim) Tem uma coisinha aí que não tá certo!... Que tem a ver com o peso!

Gomes- Peso é 50N! (ao falar volta a resolver o seu exercício) 
Ao ouvir o que Gomes falou, Tim se espantou com o valor do peso, pois ele usou o valor da massa (sem multiplicar pelo valor da aceleração da gravidade). Então se estabeleceu um diálogo entre Tim e o professor:

Tim- 50, não é 5? (verifica isto a partir da fala de Gomes, porém não se sente convencido)

Tim- 50N!?

Prof.- Você tem $5 \mathrm{Kg}$, né? Mas acontece que você tem que usar o peso e não a massa! (fala para Tim).

Alan- Em Newton!

Tim- Em Newton? (tenta se convencer)

Prof.- Assim, ó! ( mostra para Tim como fazer)

Prof. - Peso é igual a massa vezes a gravidade, que é 5 vezes 10. (escreveu na lousa para mostrar a Tim)

Tim- $A h !$ Tá

Prof. - Lembra que é sempre peso! Se ele já te deu o peso, beleza, é direto. Mas se ele te deu a massa, aí tem que calcular.

Logo em seguida, Alan comentou com o professor sobre o curso técnico que ele cursava à noite, na mesma escola, dizendo como que ele fazia exercícios semelhantes a estes no seu curso noturno. Em seguida, mostrou o apêndice do livro, indicando as grandezas físicas e suas respectivas unidades que já havia estudado. Ele comentava tudo isso com bastante entusiasmo, até que foi interrompido por Tim que solicitou ao professor sua ajuda, pois estava com dificuldades de compreender o significado de um símbolo matemático. Nesse momento, Leandro também entrou na conversa. E por fim, Alan voltou a mostrar ao professor o apêndice do livro, como fazia antes.

Passado esse evento, quem chamou o professor foi Leandro:

Leandro- Professor, então ó, hipotenusa é sempre na frente do ângulo de $90^{\circ}$ ?

O professor lhe respondeu apenas com um sinal positivo com cabeça. Quem falou algo para Leandro foi Gomes:

Gomes - Só você ver o quanto aqui ó...

Mas Leandro insistiu com o professor:

Leandro- Cosseno ... (olha para os valores na folha de Tim) é o oposto?

Então, o professor explicou para ele, enquanto os outros três discutiam um tema diferente dos primeiros. Logo em seguida o professor saiu do grupo. 


\section{7-Após a saída do professor}

Logo após a saída do professor, Leandro tentou resolver o exercício e recebeu incentivos de Gomes. Este, além de incentivá-lo, advertiu os demais para que esperassem por Leandro. Nesse instante, Gomes parou o que fazia para ajudar o colega mostrando-lhe o que e como tinha que ser feito o exercício, usando a própria resolução como exemplo.

No momento em que Gomes pediu que todos esperassem por Leandro, a única resposta que surgiu foi de Tim, que disse que só terminaria o que estava fazendo para então esperar e ajudar Leandro.

\section{8-Formação de subgrupos}

Passado o episódio, que ocorrera logo após a saída do professor, o enquadre que se estabeleceu no grupo foi o surgimento de subgrupos: Tim e Alan; Leandro e Gomes. O que cada subgrupo resolvia era independente um do outro. Porém, na medida em que os dois primeiros tinham alguma dúvida pediam ajuda a Gomes, sendo que quem verbalizava este pedido de ajuda era em geral Tim. Quando este não conseguia a ajuda de Gomes chamava o professor (e o fazia com insistência). Tim se encaminhava até o professor nas vezes em que não era atendido de imediato.

Gomes e Leandro terminaram o exercício que estavam fazendo.

\section{9-Professor retorna ao grupo}

O professor chegou ao grupo a pedido do Tim, e este como da outra vez, logo lhe perguntou se o que ele fez estava certo ou não. A resposta que o professor deu não foi diretamente para Tim, mas para os demais alunos: ele lhes perguntou se todos concordavam com o resultado que Tim havia encontrado. Gomes só ameaçou uma resposta porque ele não sabia muito bem do que o professor falava e, além disso, ele não participou da resolução do problema em questão, pois ele resolveu outro com Leandro, já que ninguém o esperou.

Nessa intervenção o professor reforçou aqueles subgrupos que se formaram anteriormente, pois depois da resposta de Gomes, ele passou interagir com Tim e Alan. Enquanto que Leandro e Gomes não só não participavam, mas cada um parecia resolver o seu exercício. 
Terminada a explicação do professor para Tim e Alan, ele ainda permaneceu um tempo parado em silêncio perto do grupo, até que ele resolveu iniciar uma conversa com Leandro. Este, ao ser questionado no que estava pensando, respondeu que viajava nas suas idéias, na sequiência o professor lhe perguntou em quais idéias viajava. O professor parecia estar interessado em inseri-lo no grupo ao "puxar papo" com esse aluno. Leandro trouxe então para o grupo outro assunto; Tim e Alan se envolveram nessa conversa do Leandro com o professor.

Gomes, enquanto resolvia o seu exercício, olhava com freqüência para a filmadora. Porém, houve um momento em que ele se manteve olhando para o aparelho, transparecendo estar incomodado com a presença da câmara. Então, depois de alguns segundos ele se voltou para seu caderno e fez um gesto com sua cabeça como quem pensava: “Ah! Vou esquecer que tem uma filmadora ali!”. Ele retornou então para o seu exercício.

Quando ia deixando o grupo, o professor pediu ao Leandro para acompanhar os outros alunos, isto é, para fazer os mesmos problemas que eles, pois a dúvida que Leandro tinha era mais geral, ou seja, não se tratava de dúvidas relativas ao conteúdo ou ao exercício específico. Leandro lhe perguntara sobre as relações trigonométricas de seno e cosseno.

\subsection{0-Saída do professor}

Após a saída do professor, Gomes pediu aos outros colegas que esperassem por Leandro, para que todos resolvessem juntos o exercício seguinte.

Logo em seguida, Gomes foi único que tomou a iniciativa para fazer algo em relação à atividade. Tim nesse momento estava ausente do grupo enquanto que Leandro e Alan observavam o que o primeiro fazia. Assim foi, até que Gomes falou com mais ênfase para Leandro resolver o exercício, porque os demais esperariam por ele. Esse comando de Gomes foi acatado pelo grupo, pois os outros pararam de resolver os exercícios.

Leandro- Não sei nem por onde começar, cara!

Gomes- Primeiro você desenha!

Enquanto Leandro tentava resolver o exercício em questão, surgiram comentários e piadinhas entre Gomes, Tim e Alan. Em seguida, Gomes olhou para a 
filmadora mais uma vez e parou de conversar, talvez numa tentativa de disfarçar a sua dispersão.

\subsection{1-Momento de dispersão dos alunos (0.33.40)}

Aqueles mesmos três alunos mantiveram a conversa paralela, enquanto Leandro oscilava entre fazer o seu exercício e conversar com os demais. Os três alunos estavam dispersos porque, segundo eles, esperavam Leandro resolver o seu exercício para que todos seguissem juntos. Contudo, Gomes alternava entre a conversa com Tim e Alan e a ajuda a Leandro.

\subsection{2-Nova entrada do professor no grupo $(0.37 .47)$}

Quando o professor chegou ao grupo a primeira reação dos alunos foi parar de falar e tentar pegar o caderno para dar uma idéia de que estavam trabalhando.

Tim- Professor.. (ia mostrar algo ao professor para tentar disfarçar)

Prof.- Só a hora que eu venho aqui que vocês resolvem os exercícios?!?!

Gomes- Não, não, professor, estamos esperando o Leandro!

Leandro- Tá ensinando eu fazer!

Com a presença do professor, uma nova configuração de subgrupo foi gerada: Leandro e Gomes; Alan, Tim e professor. No primeiro, Gomes explicava como resolver o exercício para o seu colega. Enquanto que os outros dois alunos interagiam com o professor sobre o exercício que Tim lhe mostrara. Porém, Tim era quem estava mais interessado na interação com o professor sendo para ele que o professor se direcionava enquanto falava. Alan se mostrava indisposto e se mexia muitas vezes na cadeira, olhava para os lados e algumas vezes tentava prestar atenção na interação dos dois.

\subsection{3-Final da aula}

A atividade é interrompida devido ao final da aula e isto se deu de forma repentina, ou seja, os alunos não esperavam pela sua interrupção. Dessa forma, o grupo não preparava uma síntese do que foi feito ou algo gênero. No momento que em soou o sinal indicando que a aula terminara, todos os alunos se levantaram e saíram da sala para o intervalo. Eles não se preocuparam como estava o exercício ou quem tinha feito o que para que fosse apresentado ao professor. 


\subsection{1-Análise da aula 10}

A nossa hipótese inicial é o que grupo nessa aula, se caracteriza por permanecer na pré-tarefa, pois havia uma fragmentação do vínculo entre os alunos, destes com a tarefa e com professor, fatores que marcam esta fase do desenvolvimento grupal. E de uma forma mais geral, podemos dizer que se trata de um grupo de resistência à mudança, tendo como líder desta resistência o próprio Gomes.

O professor ao convocar os alunos para resolução da atividade o faz por meio de uma intervenção institucional por se tratar de uma medida normativa: formar o grupo para resolução da tarefa. Como nesse momento o professor interveio normativamente, entendemos que ao se referir ao grupo 2 como sendo do Gomes os alunos receberiam isso como uma norma a ser seguida. O que queremos dizer é que o grupo vai se assumir de alguma forma como sendo do Gomes já que isso foi dito numa situação normativa do professor para com os alunos. Vamos verificar essa nossa hipótese em algumas recorrências da aula 10 descrita anteriormente em especial no episódio 10.10.

No episódio 10.2, vemos que Gomes teve a iniciativa para resolver a atividade, pois era o único que manuseava o livro. É nesse momento inicial que Gomes vai revelar a sua relação com a filmadora, com o pesquisador e com o próprio professor ao chamar os seus colegas para iniciar o exercício: sentia-se ameaçado. Ele revelou isso ao dizer que o professor estava "pegando eles" de todos os lados. A sua preocupação com a filmadora estará presente em vários momentos desta aula bem como nas outras duas que vamos apresentar a seguir.

Ainda no episódio 10.2, depois de convocar a todos para fazerem a atividade, Gomes insistiu especialmente com Leandro para que ele iniciasse o exercício. Essa relação com este colega se deve ao fato de que são primos e que ele estaria assumindo o papel da instituição de zelar por Leandro, uma vez que ele fora reprovado no ano anterior e tinha um histórico complicado, tanto no âmbito escolar quanto no familiar. Leandro estava matriculado nessa escola devido a uma tentativa de sua tia, mãe de Gomes e dona da escola, de ajudá-lo. Ou seja, Gomes era o depositário da instituição o que fazia com que ele tivesse essa postura perante o primo: Gomes é o depositário das ansiedades do grupo instituição, assumindo o papel de porta-voz deste grupo. 
A partir dessa idéia, podemos justificar o porquê Gomes se sentia ameaçado com a presença da filmadora e do pesquisador, pois eles poderiam revelar o "segredo" da instituição do qual era depositário. A sua relação com o professor vai se estabelecer também nesse sentido, de ameaça, porque ele é o responsável por introduzir a pesquisa na sala de aula.

Um outro evento que corrobora com essa nossa interpretação diz respeito à postura da diretora da escola nas vezes em que ia à sala de aula para dar algum aviso no momento em que ocorriam as filmagens: nessas situações ela sempre solicitava que a câmara fosse desligada enquanto ela falava. Essa sua relação com o aparelho é semelhante à de Gomes, com a diferença de que ele não pode solicitar que a filmadora fosse desligada e, justamente por isso, se portava sempre reagindo a ela durante esta aula (e nas aulas 14 e 17 também).

A ameaça que o professor representava ao Gomes se mostrou na sua fala no episódio 10.4 ao dizer "tú ta de olho em nós". Além disso, ele também encarava a tarefa como uma ameaça, pois ele encerrou sua fala com "fazer exercícios" como uma forma de o professor estar de olho neles. A essas duas expressões se junta outra que ele usou “pegando nós", no episódio 10.2. Leandro complementou a fala de Gomes, no episódio 10.4, fazendo referência a um programa de TV do tipo Reality Show em que todos os participantes são filmados e monitorados. Entendemos essa postura dele como sendo uma afirmação de uma aliança (inconsciente) com Gomes, que é o representante da instituição que o acolhe.

Podemos inferir desses eventos envolvendo Gomes e Leandro que eles formavam um tipo de grupo, isto é, nas situações em que se formavam subgrupos entre os quatro alunos, estes dois sempre estavam juntos. Podemos ainda pensar que a tarefa desse (sub)grupo seria preservar o segredo da instituição e deste ponto de vista, ao professor é atribuído o papel de sabotador.

O episódio 10.3, quando Tim iniciou a leitura de enunciado de um exercício da atividade, marcou o primeiro momento da entrado do grupo na resolução da tarefa explícita que havia sido proposta pelo professor. Porém, Gomes interrompeu o seu colega e continuou a leitura do mesmo enunciado que Tim fazia. Isso pode ser uma indicação de que ele queria mostrar que o grupo era dele, como disse o professor no início da aula, entretanto, foi com a fala de Alan que o grupo alavancou nesse momento. 
Alan assumiu o papel de líder quando estabeleceu para o grupo uma estratégia de resolução, gerando uma comunicação divergente dele para com os colegas. Observamos um encaixe entre o papel assumido e o necessitado, pois sua ação foi, aparentemente, aceita sem conflitos com os demais membros, inclusive o Gomes.

Se os alunos mantivessem essa dinâmica poderíamos observar a entrada na pertinência e cooperação. $O$ que observamos na sequiência, contudo, não foi um aprimoramento da estratégia com a circulação dos papéis e a abertura dos canais de comunicação, desfazendo aquela configuração divergente. Ao indicar a sua estratégia, cada um fazendo a sua parte, Alan introduziu uma forma de se trabalhar em grupo, que diz respeito à fragmentação da tarefa explícita e, por conseguinte, a fragmentação do vínculo entre os alunos.

A fragmentação ocorrida no grupo pode sinalizar uma representação destes alunos do que seja trabalhar em grupo, a qual traz uma resistência implícita para um trabalho operativo e cooperativo, como apontam Anzieu \& Martin (1971) indicando algumas de ordem psicológicas e sociológicas para o trabalho coletivo.

Para esses autores, o que passa com as pessoas é que elas têm uma concepção de que os grupos são frutos de uma causalidade como conseqüência das relações interindividuais espontâneas. Sob essa ótica, um grupo seria fruto de vinculações entre pessoas com empatias entre si, reduzindo-se a questões pessoais. No entanto, tais autores afirmam que estar em grupo requer um esforço individual, que consiste em mudança diante do outro e do novo. Então, para evitar pensar essa situação que levaria o sujeito a um outro marco de referência, criam-se resistências (epistemológicas) à noção de grupo.

O narcisismo e a condição contemporânea individualista do ser humano ainda seriam obstáculos para uma noção epistemológica de grupo, para os mesmos autores. Acrescenta-se aí a concepção de que o grupo se apresenta a cada um dos membros como uma barreira para obtenção privilegiada com o líder ou com outro membro, de acordo com os processos de múltiplas transferências.

No grupo em questão, essa forma de proceder pode ser entendida como uma fantasia dos alunos para se trabalhar em grupo, segundo o que apresentamos acima. No entanto, a sustentação dessa fantasia, como veremos nos episódios seguintes, se 
transforma em uma resistência à mudança e se converterá em obstáculo para a aprendizagem do grupo, caracterizando a fase da pré-tarefa

Assim, aquela estratégia de Alan deveria ajudar o grupo a superar essa fase passa atuar como obstáculo epistemológico, já que na leitura da realidade "estabelecese uma distância entre o real o fantasiado" (PICHON-RIVIÈRE, 2005, p. 34). Como marca dessa fase, o grupo vive momentos de pouca interação e de silêncio entre eles, como descrevemos no episódio 10.3 , característicos da afiliação.

O episódio 10.5 nos mostra dois fatos que nos parecem interessantes: a insistência de Gomes em operar a conta matemática na calculadora e a fala de Leandro perguntando aos seus colegas como se calculava " $\mathrm{P}_{\mathrm{y}}$ ". A primeira, quando Gomes tirou a folha da resolução das mãos de Tim, pode estar relacionada ainda àquele momento em que o professor se referiu a este grupo como "grupo do Gomes". Então, essa sua postura seria uma forma de afirmação daquela fala do professor, que caracterizamos como uma intervenção institucional. E a outra, mostra, de um lado, Leandro numa tentativa de se comunicar com o grupo e, por outro, o descaso dos demais colegas para com ele.

Os dois fatos ocorreram em um momento em que os alunos iniciaram uma discussão mais aprofundada sobre o plano inclinado, que era tema do exercício em questão. Como parte natural desse processo, Leandro tentava interagir com os demais lhes fazendo perguntas sobre aquilo que nos parece ser o mesmo assunto. A não correspondência dos demais nos dá mais um indício de que o grupo estava fragmentado e individualizado, e nessa situação Leandro assume o papel de porta-voz dessa fragmentação.

Sustentamos essa idéia, pois as perguntas que Leandro fazia estavam deslocadas daquilo que os demais resolviam, por mais que a noção de " $\mathrm{P}_{\mathrm{y}}$ " estivesse relacionada com o exercício. O grupo não percebeu o conteúdo implícito da fala de Leandro e optou por rejeitar o colega do processo de discussão (vide fala de Alan). Ele então passou a observar o que os outros faziam e algumas vezes tentava fazer algo em seu caderno.

O episódio 10.6 é iniciado com a chegada do professor no grupo e com uma intervenção institucional, porque ele questionou se todos estavam fazendo o exercício juntos. Entendemos essa cobrança como um enquadre normativo para o grupo, por isso trata-se de uma intervenção institucional. Ressaltamos que o professor tinha uma preocupação particular para com esse grupo em saber se todos participavam da 
resolução do exercício, pois desde o primeiro semestre ele já havia percebido a predominância de um aluno nas ações do grupo e isso o incomodava.

Devido a isso, percebemos o professor rondando o grupo, ou seja, se aproximando dos alunos, mas sem lhes falar nada. Ou ainda, quando um dos alunos do grupo lhe apresentava uma dúvida sobre o exercício, suas respostas eram curtas. Podemos inferir a partir daí que o professor percebia que o grupo estava fragmentado, porém as suas intervenções não conseguiram resolver isso.

É possível compreender as intervenções do professor sob dois aspectos: desde como ele enxergava o grupo e como o grupo lhe enxergava. E essa dualidade constitui um ponto essencial da análise: o professor ao mesmo tempo em que é o coordenador do grupo não está isento das múltiplas transferências aí ocorridas, e sobre ele são depositados os conteúdos latentes do grupo, cuja conseqüência é atribuição de papéis a ele.

Se então considerarmos o professor como um membro do grupo, podemos dizer que ele se torna porta-voz dessa fragmentação ao se aproximar dos alunos e lhes dirigir perguntas como: “O grupo fez junto? Cada um tá fazendo individual aí?”. Contudo, é possível dizer, devido à reação dos alunos, que lhe fora atribuído o papel de sabotador, porque que não coopera para a ação do grupo em manter-se fragmentado.

Desse ponto de vista que estamos oferecendo, não ocorreu no grupo aquele acoplamento entre o papel assumido e o necessitado. Isso implica dizer que, nessa fase em que grupo se encontrava era preciso que o professor atuasse nem tanto de forma institucional, mas presencial, ou seja, assinalando e interpretando os feitos do grupo.

A intervenção presencial poderia ajudar o grupo a desbloquear os canais de comunicação entre os alunos e entre estes e o professor, de tal forma que a fragmentação, conteúdo implícito do grupo, se tornasse explícita num processo de elaboração: trata-se, portanto, da resolução da tarefa implícita que o grupo deveria cumprir para experimentar um salto qualitativo e assim dar conta da tarefa objetiva, que era a resolução do exercício.

As ações do professor, na seqüência, parecem contradizer a nossa interpretação explicitada no parágrafo anterior, pois ele permaneceu no grupo, conversando com os alunos. Inicialmente com Tim cujo tema era o próprio exercício e depois com Alan, que estava empolgado em lhe contar sobre o seu curso noturno. Porém, mesmo ele 
permanecendo no grupo, ele atuou de forma a reforçar aquela fragmentação já existente porque sua intervenção era sempre direcionada somente a um aluno, e todos eles estavam fazendo coisas diferentes, enquanto que o professor conversava com um deles.

Há ainda neste episódio 10.6 um fato que merece nossa atenção: Leandro chamou o professor para lhe fazer uma pergunta. O interessante aqui é notar que o tema da dúvida desse estudante é periférico em relação ao exercício. Tratava-se de uma dúvida mais geral: trigonometria. Entendemos que nesta chamada, havia mais do que uma dúvida, havia um pedido de ajuda. Era como se Leandro estivesse tentando mostrar ao professor que ele estava no grupo, já que os outros membros em geral não o faziam. Sendo assim, a pergunta de Leandro era pretexto para chamar a atenção do professor. Gomes, seu primo, tentou ajudá-lo, mas ele queria que o professor lhe explicasse, reforçando assim a nossa interpretação. Gomes teria reagido daquela forma, tentando ajudá-lo antes mesmo do professor, pois era "missão" dele zelar por Leandro e, como salientamos, esta missão lhe fora depositada pela própria instituição.

O mais importante do que ressaltamos acima é a percepção de que $a$ inclusão do Leandro no grupo é parte da tarefa implícita do grupo que deveria ser resolvida a fim de que se estabelecessem indicativos de mudança.

A não inclusão de Leandro nas ações do grupo pode ser interpretada desde um outro ponto de vista: Alan e Tim não assumiram a missão de Gomes de zelar por aquele aluno. Se pensarmos assim, entendemos a reação do grupo mediante o pedido de Gomes para que todos esperassem por Leandro, ou seja, aqueles dois estudantes seguem com suas atividades, como indicou Tim, dizendo que terminaria o que estava fazendo para então esperar pelo colega (episódio 10.7).

Com a saída do professor, vemos a formação do mesmo subgrupo. Agora nos é mais evidente, todavia, o porquê desta configuração: Gomes está exercendo seu papel de cuidar de Leandro formando um subgrupo enquanto os dois alunos seguem no esquema que o próprio grupo se instituiu no começo que é cada um fazendo a sua parte. Resgatamos aqui a idéia do início desta análise sobre a aliança entre Leandro e Gomes que condicionava a formação deste subgrupo, dando mais significado a nossa interpretação.

Novamente o professor foi chamado por Tim para ir até o grupo, pois era este aluno que estava com dúvidas, marcando assim o início do episódio 10.9. Como da 
outra vez, o professor não respondeu diretamente àquele aluno, mas retornou para todos os demais questionando se havia concordância no resultado encontrado por Tim. Essa postura do professor pode confirmar a nossa interpretação já apresentada anteriormente: ele percebia que o grupo estava fragmentado, porém intervinha de tal forma que não conseguia romper com a fragmentação que se estabelecera entre os estudantes.

Vemos na seqüência o mesmo movimento do professor em relação ao grupo, ele permaneceu com os alunos, mas não atuou de forma a desfragmentá-los e oferecer-lhes condições para um salto qualitativo em seu processo enquanto grupo. Contudo, o professor passou a "viajar" nas idéias de Leandro, tendo sido este motivado a falar o que pensava. Essa sua ação para com este aluno nos indica a tentativa de incluí-lo no grupo, ou então de responder aquela chamada de atenção the fora solicitada por esse mesmo aluno por meio de uma dúvida mais geral (episódio 10.6).

Um evento neste episódio pode nos dar indícios de que o professor tentou incluir Leandro ao "viajar" nas suas idéias. Antes de ele deixar o grupo ele pediu a este aluno que acompanhasse o que outros estavam fazendo. Logo, se fora pedido isso a Leandro era porque o professor percebera que este aluno estava alheio ao que se passava no grupo. Ao pedir isso, o professor atuou de forma institucional em relação a todo grupo, ou seja, fora pedido para Leandro se interar com o grupo e para o grupo aceitá-lo.

Essa intervenção foi correspondida por Gomes, que a reproduziu aos colegas, pedindo-lhes, com autoridade, para que esperassem por Leandro, como vemos no início do episódio 10.10. Gomes nesse momento assumiu o papel de líder autocrático, mas foi atendido pelos outros colegas.

É interessante notar que houve um acoplamento entre o papel assumido e necessitado, indicando assim que o professor não tinha controle sobre esse grupo, ou então, que quando ele atuava de forma institucional obtinha efeitos dependendo da colaboração de Gomes. Este atuou de forma autocrática, reproduzindo a norma que o professor deixou ao grupo e foi atendido. Gomes, para o grupo, ocupa o lugar institucional do professor.

O único que ajudou Leandro foi o próprio Gomes enquanto que os outros se dispersavam com assuntos diversos (episódio 10.11). E ainda, atribuíram o papel de bode-expiatório a Leandro pelo não cumprimento da tarefa, como observamos nas falas do episódio 10.12. Novamente aqui há um acoplamento de papéis, pois Leandro aceitou 
ser o bode-expiatório do grupo. Parece, então, que esta foi a maneira pela qual este aluno foi incluído no grupo.

Ainda no episódio 10.12, vemos aquela configuração dos subgrupos, Leandro e Gomes; Alan e Tim. Estes dois últimos se mantiveram interagindo com o professor enquanto os outros dois interagiam entre eles. $\mathrm{O}$ fato de Gomes em geral não interagir com o professor durante a sua estadia no grupo nos parece ser consequiência daquela primeira fala: "O grupo do Gomes". Desde então, este aluno vê no professor um concorrente e uma ameaça constante (“Tu tá de olho em nós, hein professor!” - episódio 10.4). Ou seja, o lugar institucional do professor no grupo é ocupado por Gomes, e os alunos aceitam essa condição, dado que o professor autorizou isso com aquela primeira fala.

Ao invocarmos o referencial que estamos usando para tentar entender o estancamento da tarefa e da comunicação entre os alunos e o professor, damos-nos conta de que o ruído em todo esse processo do grupo nesta aula é a própria instituição. Gomes, como depositário desta, passa atuar de forma a não revelar o segredo diante da filmadora (por isso ele olha com freqüência para o aparelho demonstrando estar incomodado com a mesma) e interpreta as ações do professor como ameaças a ele e a instituição. O obstáculo (epistemológico) do grupo está nessa relação truncada entre Gomes e o professor que interfere em todo sistema de comunicação dos alunos.

Concluímos então que, do ponto de vista do processo grupal esperado tanto pelo professor quanto pelo pesquisador, este grupo nesta aula não experimentou uma mudança que o deslocaria da fase da pré-tarefa. Os alunos não conseguiram superar a fragmentação, que seria parte da tarefa implícita a ser resolvida, o que gerou um estancamento da tarefa objetiva, como é possível observar no episódio 10.13. Ao término da aula, os alunos desfizeram a configuração de grupo e não manifestaram nenhuma preocupação com a tarefa: era como se sentissem aliviados pelo fim da aula. 


\section{3-Aula 14: os episódios (30/09/2004)}

\section{1-Momentos iniciais}

A aula foi iniciada com uma exposição do professor sobre o conteúdo em questão e após esta parte os grupos foram formados. Nos momentos seguintes à parte expositiva, enquanto os alunos se organizavam nos grupos, o professor entregou trabalhos, testes e provas corrigidos com as notas. Isso causou uma confusão na turma que tardou o início das atividades dos grupos de tal forma que foi necessário o professor pedir aos alunos que se organizassem. Como havia aquele alvoroço na classe o professor foi mais enfático em seu pedido:

Prof- O que vocês estão esperando pra juntar? (e faz um sinal com a mão indicando que era para se juntarem em grupos)

Após o pedido do professor, o primeiro grupo a se organizar foi o grupo 1, sendo seguido pelo grupo 3. Os alunos do grupo 2 apresentaram uma lentidão para se juntarem, pois estavam dispersos pela sala de aula. Quando começaram a se formar, Gomes foi o último que se agregou aos demais colegas. Enquanto os grupos se organizavam, foi possível ouvir as falas iniciais deles. De modo geral, tratavam das divisões das funções entre eles, como por exemplo, "hoje eu sou o Líder" ou então "hoje eu sou Questionador".

Com a filmadora já voltada para o grupo 2, registramos os seus primeiros atos, que não diferem daquilo que os grupos também faziam, que era dividir as funções. Alan se manifestou em alta voz dizendo que seria o Questionador. Logo depois da divisão das funções, iniciou-se no grupo um movimento contrário a filmagem através de comentários sendo que Gomes foi quem tomou a iniciativa, ainda que o fizesse em tom de brincadeira No que diz respeito à atividade, os alunos não pareciam muito dispostos para realizá-la, pois tinham os seus cadernos fechados e conversavam sobre outros assuntos.

\section{2-Primeira chegada do professor no grupo $(0.10 .00)$}

Quando o professor chegou ao grupo ele logo falou:

Prof- Ó, eu to preocupado com vocês!

(Silêncio de expectativa)

Alan- Preocupado com quem, professor? (quebra o silêncio) 
Após sua fala, o professor entregou alguns exercícios antigos que ele corrigiu, fez alguns comentários sobre os mesmos e pediu que os alunos explicassem o que eles tinham feito na resolução. Gomes e Alan se prontificaram para tal e o quadro que se estabeleceu foi o professor interagindo com estes dois alunos enquanto os outros dois tinham uma participação mais periférica.

Na conversa com o professor Alan, que demonstrava preocupação com as notas (e era o único neste grupo), lhe perguntou quanto valiam os exercícios que eles sempre resolviam nas aulas. Dois fatos podemos destacar dessa fala de Alan:

- foi a primeira vez que alguém perguntou ao professor o valor das notas das atividades de aula;

- ao se referir aos trabalhos que eram feitos durantes as aulas, ele os nomeou como "atividades de aula" e não como "atividades de grupo". Este evento terminou com a saída do professor que lhes pediu para iniciar a atividade daquela aula.

\section{3-Saída do professor e recusa à pesquisa $(0.12 .20)$}

Assim que o professor saiu do grupo Alan foi o primeiro a abrir o livro e, embora tenha reclamado da quantidade de exercícios, ele se mostrava disposto a fazêlos e a interagir com os demais alunos. Ele, então, pediu ao Gomes que pegasse a folha na qual seriam escritas as anotações do grupo para então dar-se início aos trabalhos de grupo. Alan se frustrou quando Gomes não lhe correspondeu.

Alan- Que página que é pra fazer?

Leandro- Página 77

Alan- Vai, Gomes, pega o folha ae, do caderno!

Gomes- Pô! Cada um tem que ler o seu!

Alan- Não! (responde com certo espanto)

Gomes- Isso é!

Alan- É?

Gomes- É!

Alan-Você tem certeza? (pergunta a Gomes ainda desconfiado da resposta do colega).

Gomes- Tenho!

Em seguida, os alunos manifestaram um tipo de recusa à pesquisa quando Gomes tomou a iniciativa de desligar o microfone e em seguida ligá-lo. A partir disso Alan se empenhou em atrapalhar a filmagem golpeando com chutes no pedestal do 
microfone, dificultando a captura do som. Ele continuou fazendo isso um longo período até que ou se distraiu com outra coisa ou ele se cansou chutar o pedestal. Em seguida, Tim se questionou quando terminaria a pesquisa do professor, para não serem mais filmados.

Tim- Ou, este trabalho do professor que filma nós, não tá terminando não?

Gomes- Vai até o final do ano! (fala se mostrando desanimado com esta situação)

Alan- Até nós saí do primeiro!

Gomes- Chega ano que vem junta tudo de novo!

\section{4-Gomes recusa a tarefa $(0.15 .10)$}

Quem demonstrava interesse em resolver a atividade era Alan. Ao iniciar a leitura de um dos exercícios ele encontrou dificuldades e foi pedir a ajuda de Gomes. Sua dúvida não estava relacionada com o assunto da aula, mas algo que era um prérequisito. Gomes estava envolvido numa conversa e brincadeiras com Tim e com os alunos do grupo 3 e não correspondeu ao colega.

Alan- Meu irmão! Meu irmão (chama por Gomes) Onde está aquele bagulho de atrito que você falou para mim

Alan insiste com Gomes, ainda assim:

Alan- Onde tá o bagulho?

Gomes- Vê a pagina lá, ajuda! (aponta para a lousa)

Alan- Qual? ... Não!... atrito lá que você me falou!

Alan mais uma vez não obteve sucesso nas suas tentativas de diálogo com Gomes, o qual estava totalmente distraído e aparentava desinteresse pelo exercício a fazer. Mas Alan tenta novamente a ajuda de seu colega:

Alan- Onde tá aquele sobre gravidade, que você falou do plano inclinado... ô Gomes! (Gomes nem olha para Alan)

Alan- Ô Gomes! (então aí é que ele olha para Alan)... brigado viu! (fala decepcionado)

Alan- Gomes!

Alan- Ei! Aquele bagulho do... do... do atrito, que página que é?

Gomes- Vai procurando aí que você acha! (mais uma vez ignora Alan)

Alan mesmo não tendo sido correspondido pelo colega por quem chamava ainda tentou fazer alguma coisa em relação à atividade, mas também se envolveu na conversa com os demais colegas do grupo. 
Depois de alguns minutos, Gomes encerrou a sua conversa com os colegas e se voltou para o seu caderno. Neste momento, Alan tentou mais uma vez a ajuda de Gomes e lhe fez uma pergunta:

Alan- Gomes, você não vai me ensinar?

(...)

Alan- Qual é a diferença entre atrito estático e atrito dinâmica? Atrito estático é parado...

Gomes- Atrito estático é quando não tem velocidade, pronto! Alan-Beleza! (fala frustrado) ...que página que é? 77?

Gomes respondeu para Alan mostrando indisposição para com ele e em seguida se voltou para o seu caderno, indicando que ia resolver algo. Alan era quem demonstrava até então maior interesse pela a tarefa, dando indícios de que estava ao menos tentando resolvê-la.

Os alunos estavam dispostos de tal forma que gerava algumas dificuldades técnicas para a captação de som e imagem. Alan estava em uma posição tal que ficava de costas para a filmadora (quase de frente para Gomes); Gomes estava próximo ao aparelho, mas de costas e os outros dois estavam mais distantes e lado. Essa formação se manteve assim até quase o final da aula.

\section{5-Passagens do professor pelo grupo $(0.22 .20)$}

Ao perceberem que o professor estava passando pelo grupo, Tim e Lucas mudaram suas posturas e se voltaram para os seus cadernos para simular que estavam fazendo a atividade.

O professor enquanto esteve no grupo não falou nada aos alunos nem mesmo fez cobranças sobre a tarefa ou sobre as funções, mas foi questionado por Alan que queria saber sobre a matéria que cairia na prova e lhe perguntou ainda o resultado de uma operação matemática que estava resolvendo.

É interessante notar a postura de alguns enquanto que o professor estava presente no grupo: havia uma tentativa mais evidente de resolver os exercícios e de interação entre eles e deles com o professor; Alan lia em voz alta o enunciado de um exercício e Leandro o acompanhava; Tim fazia uma leitura silenciosa e depois perguntava ao professor. Porém, ele não lhes respondia nada e logo em seguida saiu de perto do grupo. 
Aquela operação matemática em que Alan estava interessado virou tema de debate entre os alunos que se mobilizaram para resolvê-la, com exceção de Gomes que naquele momento estava interessado em procurar a sua borracha que havia sumido. Ao perceber que estava fora da discussão dos outros alunos, ele perguntou, então, para Alan:

Gomes- Vocês estão calculando o quê?

E depois ele falou para o grupo:

Gomes- Opa! É comigo mesmo!

Durantes esses eventos, Gomes aparentava ainda estar incomodado com o microfone da pesquisa que estava perto dele.

O que se seguiu depois deste episódio foi uma fragmentação do grupo: Leandro e Alan resolviam o exercício, embora o primeiro observasse mais do fazia. Tim se mantinha um pouco mais afastado dos seus colegas enquanto resolvia, porém se dispersava com muita facilidade com outros assuntos que ele mesmo trazia, e que em geral contribuía para a dispersão dos outros também; Gomes se mantinha sozinho resolvendo o seu exercício e quando se manifestava ao grupo fazia comentários contrários à filmagem ou de recusa da tarefa.

Como nas situações anteriores, Alan tentava aqui também a ajuda de Gomes para a resolução do exercício, mas as repostas que recebia eram sempre caracterizadas com a indiferença de seu colega:

Alan- Ô Gomes, como é que acha a força resultante? ... Trabalho resultante?

Gomes- Trabalho de um mais o trabalho do outro! (responde com um pouco de demora)

O setting grupal se manteve dessa forma mesmo com algumas passagens do professor que somente se aproximava dos alunos. Ele os observava e saia sem lhes falar nada. Nesses momentos, se Tim estivesse disperso, voltava a fazer o seu exercício. Essa configuração que durou cerca de dez minutos é marcada ainda pelo silêncio e pela falta de interação entre eles quando pareciam resolver a tarefa.

Entre algumas das interações que surgiam quebrando os momentos de silêncio, destacamos uma que nos parece importante envolvendo Leandro, Gomes e Alan. O assunto foi gerado por uma dúvida que Leandro trouxe para o grupo:

Leandro- Um milhão tem quantos zeros (pergunta para Gomes) 
Gomes- seis zeros (pensa antes de dar a reposta)

Leandro- Seis?

Alan- Ah! Não falei! (fala para Leandro)

Leandro- Cem mil é quanto?

Gomes- Cem mil? ... Três zeros!

Ao ouvir a reposta de Gomes, Leandro ainda permaneceu desconfiado e foi tentar conferir consigo próprio, escrevendo os valores no seu caderno para fazer a verificação. Ele recebeu ajuda de Gomes, que lhe explicou com mais detalhes. Essa paciência de Gomes para com Leandro foi observada também na aula 10.

\section{6-Presença do professor no grupo (0.34.48)}

Inicialmente o professor interagiu com Gomes e, Tim que observava os dois, também entrou na conversa. Por fim, Alan também se interou do assunto com os outros três. Os temas das perguntas passaram a ser a prova que teriam que fazer e quem estava mais preocupado era Alan. Então, iniciou-se um momento de diálogo entre todos do grupo cujo tema era a prova e como estudar.

Alan-Professor, na prova tem as fórmulas todas ou não?

Prof.- (responde que não com a cabeça)

Alan- Não!?

Tim- Professor!? (também fala espantado com a reposta do professor)

Alan- Não dá para saber todas, têm tantas!

Prof- Do jeito que vocês estudam não dá mesmo! O problema está nos exercícios!

Em seguida desse momento em que professor tentava incentivá-los a estudar de uma forma diferente daquelas que estavam acostumados, ele se manteve conversando com Tim, enquanto que Leandro e Gomes também ouviam a conversa e Alan tentava resolver o exercício. Também nesses momentos, Alan pedia auxílio a Gomes que lhe dava repostas curtas e indiretas como todas as outras vezes.

Depois de uns cinco minutos dialogando com os alunos, o professor os deixou e a configuração que se estabelecera foi a mesma que estava antes, a de fragmentação. Há, entretanto, uma diferença aqui, pois os alunos quebravam o silêncio para confirmar com alguém o seu resultado. 


\section{7-Momentos finais da aula $(0.41 .50)$}

Leandro, que antes acompanhava Alan, na resolução da tarefa, passou a acompanhar Tim no que ele fazia. Surgiu então um comentário dele para Tim e Gomes que nos pareceu interessante:

Leandro- você finge que está fazendo, só pra quando o professor assistir a fita pensar que a gente tá fazendo.

Motivados por isso, os alunos então fizeram mais alguns comentários sobre a filmadora. Alan era o único que fazia o exercício e sempre que chegava a algum resultado pedia a Gomes que confirmasse a sua reposta.

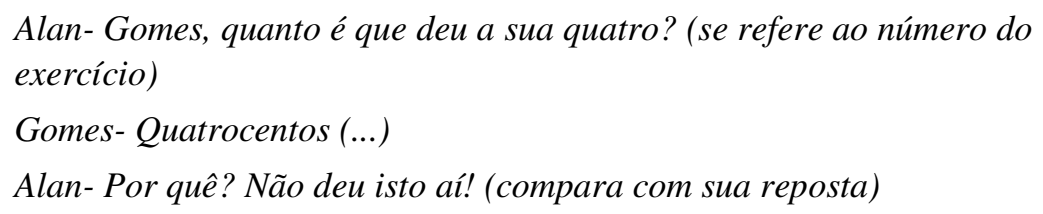

Alan ao ouvir do colega a sua reposta, prontamente questionou o resultado dele, afirmando haver algo de errado, pois as duas respostas não estavam compatíveis. Mesmo assim, Gomes encerrou suas atividades antes dos outros e Tim, que se dispersou por vários momentos pegou o caderno de uma colega de outro grupo para copiar as respostas. Seguindo o primeiro, o grupo todo encerrou por conta própria os exercícios de Física, buscando atividades de outras disciplinas, antes mesmo de soar o sinal de término da aula.

\subsection{1-Análise da aula 14}

As funções de Líder, Anotador e Questionador já haviam sido outorgadas aos grupos e como indicamos no capítulo do referencial teórico, elas atuaram como uma intervenção institucional, pois exerceram um papel normativo e organizacional nos

grupos. É perceptível isso no início da aula, pois os alunos iniciaram suas atividades decidindo quem ia assumir o quê. Em 14.1, reparamos no grupo 2 que Alan se intitulou como sendo o Questionador.

Ainda no episódio 14.1, encontramos uma outra intervenção institucional do professor, quando ele solicitou à classe que se dividisse nos grupos. Podemos dizer que sempre as atividades de grupo serão iniciadas por meio dessa intervenção, mas nesta aula os alunos estavam agitados devido aos seus resultados e à proximidade da prova bimestral. 
Em seguida, há uma movimentação dos alunos do G2 em criticar a presença da filmadora, iniciada por Gomes. Vemos aqui um fato que será comum nesta aula, que é a reclamação dos alunos por serem filmados. Além disso, a liderança de Gomes nas reclamações corrobora a nossa hipótese de que ele estaria se sentindo mais ameaçado que os demais com a pesquisa, porque ele seria o depositário das ansiedades da instituição.

Por esses motivos, e alguns outros que vamos ainda apresentar, já podemos afirmar que este grupo poderia ser classificado como o grupo da resistência à mudança e da estereotipia dos papéis. Resistem, assim, ao professor, à tarefa e ao pesquisador, que passou a ser visto como um "comparsa" do primeiro. Nesse processo de resistência, parece que o grupo assumiu outra tarefa, que eles próprios se autorizaram a cumprir: passar o tempo enquanto estão juntos com outras atividades e manter o grupo unido em torno do Gomes que representa a instituição e é o guardião do seu segredo.

A primeira intervenção direta do professor no grupo (episódio 14.2) é institucional por dois motivos:

- porque se relacionava aos aspectos burocráticos da aula, notas e correção de exercício;

- $\quad$ porque a fala do professor teve um tom normativo.

A mensagem enviada pelo professor poderia ser "traduzida" em: "Vocês não estão fazendo o que eu estou pedindo nos exercícios, alguma coisa está acontecendo com vocês!”. O silêncio inicial que se formou entre os alunos, imediatamente após o professor falar, pode nos indicar que ele teria tocado num ponto nevrálgico do grupo, indicando para eles que o professor estava de alguma forma percebendo a resistência deles em resolver os exercícios e entrar na fase da tarefa. Era como se o professor (quase) percebesse que eles elegeram uma outra tarefa para ser cumprida, que não era a mesma que ele havia deixado.

Podemos recorrer àquela Teoria dos 3D (PICHON-RIVIÈRE, 1994), que foi apresentada no capítulo sobre o referencial teórico, para tentar entender melhor a situação gerada no grupo com essa intervenção: ele depositou a sua preocupação e desconfiança no grupo e Alan foi quem se fez depositário dessa intervenção, pois logo em seguida ao momento de silêncio, foi ele o único que lhe correspondeu, demonstrando-se interessado em saber com quem o professor estava preocupado. 
Então, a pergunta neste momento é: por que Alan se fez depositário? Podemos respondê-la assumindo nossa concepção pichoneana de grupo, em que o sujeito é produzido numa práxis, ou seja, o sujeito é produzido no grupo. Isso significa que estava em jogo tanto a verticalidade de Alan, quanto a horizontalidade do grupo, a sua necessidade e a necessidade do grupo.

Quanto ao primeiro aspecto, Alan se preocupou com as notas, com o quanto valiam os exercícios que faziam em aula porque precisava obter notas boas e quando o professor disse que estava preocupado, ele logo se manifestou como quem estava dizendo: "é comigo professor?". Trata-se da sua necessidade.

Mas por outro lado, é possível dizer que ele se assumiu o papel de porta-voz do grupo, vigorando a necessidade coletiva que consistia em saber qual era a preocupação efetiva do professor em relação ao grupo, ou seja, a pergunta de Alan pode ser entendida como um tipo de verificação (do grupo por meio dele) se o professor percebera ou não que o grupo havia assumido outra tarefa. Do ponto de vista dos alunos, o professor podia "estar jogando um verde" para descobrir o que se passava no grupo, dado que os resultados, em termos de notas e do processo grupal, não eram os esperados.

Parece-nos razoável pensar assim, porque embora apresentemos neste trabalho apenas três aulas para análise, os encontros eram semanais e o professor tinha um controle relativo do encaminhamento do grupo e contava ainda com um retorno que o pesquisador lhe dava a cada aula.

A partir daí, Alan passou a atuar de forma ambígua no grupo, exercendo ora a o papel de líder da tarefa que o professor outorgara, ora como sabotador da mesma tarefa quando assumia, junto com os demais, a tarefa do grupo. Quando ele exercia o primeiro papel estava prestando contas ao professor, de quem se fez depositário; e exercia o outro quando passava o tempo juntando-se aos demais em outras atividades, entre elas recusar a pesquisa golpeando o pedestal do microfone.

Ainda no episódio 14. 2, percebemos que quem interagia com o professor eram Alan e Gomes, que lhe explicava os exercícios anteriores. Sua atuação pode ser entendida como uma maneira de mostrar ao professor que o grupo estava fazendo o que ele solicitava, e que não havia motivos para aquela preocupação manifestada no início do episódio. Além disso, é significativo o fato de que tenham sido esses dois alunos a 
dar as explicações, pois Alan se fez depositário da preocupação do professor e Gomes precisava mostrar que acompanhava o grupo fazendo os exercícios nas aulas.

A telê do grupo enquanto o professor se manteve com eles foi institucional, desde sua fala inicial até quando ele os deixou, solicitando que os alunos fizessem a atividade daquela aula. Classificamos assim porque não houve uma intervenção presencial, no sentido do favorecimento da circulação dos papéis e das múltiplas transferências, sobre tudo entre professor e aluno e tão pouco o professor assinalou ou explicou porque estava preocupado, não dando um retorno ao grupo.

A última ação do professor no episódio 14.2 foi outra intervenção institucional, ao solicitar que o grupo iniciasse a atividade da aula em questão. Esse pedido do professor nos leva a pensar que ele não estava totalmente convencido das explicações que recebera dos alunos. Acrescentamos ainda que o professor já acompanhava este grupo desde o primeiro semestre e em conversas informais com o pesquisador dizia-se preocupado $^{24}$, pois tinha a impressão de que o grupo não funcionava (como esperado).

No episódio 14.3, vemos Alan numa tentativa de resolver os exercícios, ao tomar a iniciativa de abrir o seu livro e chamar os colegas para acompanhá-lo na resolução da atividade que o professor tinha pedido para aquela aula, inclusive reforçando o pedido ao sair do grupo. Ao fazer isso, ele assumiu o papel de líder já que ele se fez depositário daquela primeira intervenção e acatou o pedido do professor de resolver a tarefa que ele lhes deixou.

Alan iniciou sua empreitada chamando Gomes para ajudá-lo e assim resolverem juntos a atividade. Mas para a sua surpresa, este o rechaçou neste momento inicial da atividade e manteve-se com esta postura por quase toda a aula, dando a entender que ele não iria resolver a mesma tarefa que o primeiro.

O diálogo entre esses dois alunos se apresenta como um emergente da situação grupal, cujo conteúdo implícito pode significar o seguinte: "cada um fará o seu, pois se fizermos juntos vamos ter que abrir mão da nossa tarefa, que é passar o tempo fazendo outras atividades!". E quanto ao fato que "cada um tem que ter o seu”, Gomes tinha certeza, como expressou na sua fala no episódio 14.3.

\footnotetext{
${ }^{24} \mathrm{O}$ professor em uma das aulas, ao notar que o grupo não atuava como esperado, deu-lhe uma atividade exclusiva, que consistia em um exercício aberto cuja solução os alunos teriam que apresentar ao longo das aulas. O intuito, segundo revelou o professor, era fazer com os alunos trabalhassem juntos, ainda que fora da escola, na esperança de que teria algum efeito na sala de aula.
} 
Gomes o teria rechaçado, pois para ele Alan atuava como sabotador, não da tarefa do professor, mas da tarefa que o grupo assumiu e só deixaria de ser visto assim pelo colega, se passasse atuar como sabotador do professor. Nesse episódio é que os conflitos de Alan se iniciaram devido à ambigüidade de papéis que ele vivenciou nesta aula.

O evento seguinte ao diálogo entre esses dois alunos pode reforçar nossa interpretação: Gomes brincou com o microfone, desligando e ligando-o algumas vezes sucessivas. Entendemos que isso faz parte de uma das atividades de "passar o tempo". Os demais alunos se mostraram ativos nessa tarefa deles, pois cada um assumiu uma etapa: um teve a idéia chutar o pedestal do microfone, outro a executou, um terceiro desligava o microfone e um outro ainda se manteve chutando o pedestal.

É possível dizer que o grupo vivenciou um momento cujos vetores são a cooperação e pertinência, pois havia de certa forma, uma complementação dos papéis assumidos pelos alunos. Isso nos leva a dizer que quanto mais o grupo fugia da tarefa que o professor lhes deixou, mais operativo ele se tornava na tarefa que assumiu para si.

Quanto à insatisfação de Tim, questionando o professor por meio da filmadora sobre o período em que eles estariam sujeitos a câmara, nos indica um outro emergente grupal: a insatisfação do grupo de não estar totalmente livre para executar a sua tarefa. Nesse momento, Tim assumiu o papel de porta-voz, cujo conteúdo implícito é justamente essa insatisfação. Além disso, é possível dizer também que houve um encaixe entre os papéis assumido e necessitado, pois ele assumiu o papel de líder da tarefa do grupo, propondo aos colegas outras atividades para passar o tempo (esta sua postura será mais evidente na aula 17).

Chamam-nos atenção no episódio 14.4 as tentativas de Alan em se comunicar com Gomes para que este lhe ajudasse com os exercícios do livro. Esse fenômeno nos indica que Alan de fato vive uma ambigüidade dentro do grupo, como já apontamos anteriormente, de ora buscar dar conta da demanda do professor da qual ele se fez depositário, ora compactuar com o grupo no cumprimento de outra tarefa. Parece-nos curioso também o fato de que Alan sempre chamava o mesmo colega para ajudá-lo, e nunca um outro, sendo insistente, mesmo recebendo reposta que nos pareciam 
grosseiras. Então, nos perguntamos: por que Alan insistia somente com Gomes e não chamava os outros colegas para ajudá-lo?

Podemos buscar uma possível resposta ao tentar interpretar uma fala de Alan a Gomes, no episódio 14.4: “o atrito lá que você me falou!”. Falou quando? Onde? Embora não podemos afirmar categoricamente, inferimos que Gomes não podia ajudar o colega no setting do grupo, mas fora sim; e pela fala de Alan parece que era comum os dois estudarem juntos. Já durante a aula, enquanto estavam em grupo havia um tipo de pacto, motivo pelo qual estavam juntos, que não permitia que Gomes o ajudasse. $\mathrm{O}$ fato de serem filmados reforçava essa situação, pois havia a possibilidade de "entregarem o ouro ao bandido", o que significa que o professor poderia descobrir que havia uma outra tarefa assumida pelo grupo.

O evento envolvendo uma operação matemática com a calculadora e algumas passagens do professor pelo grupo marcaram o episódio 14.5. Essas passagens se caracterizam somente pela proximidade do professor, sem lhes perguntar ou falar nada. A reação de Tim e Leandro era simular que estavam resolvendo os exercícios.

Vemos nesse episódio um exemplo da intervenção virtual em que a presença do professor representa um ruído na comunicação entre os alunos. Parece-nos razoável afirmar que a ação dos alunos em simular (ou até mesmo resolver) a atividade quando ele se aproximava do grupo é como aquela conversa no telefone entre duas pessoas que começam a falar em códigos porque suspeitam a presença de um terceiro. Dessa maneira, o grupo resolvia a tarefa que o professor lhe pediu para que ele não percebesse que havia uma outra assumida pelo grupo: resolver os exercícios quando o professor estava próximo era o código que escondia a outra tarefa por eles assumida.

A idéia lançada acima se completa ao inferirmos que as passagens do professor próximo ao grupo eram no sentido de sondar os alunos para verificar o que de fato eles faziam. Isso faz mais sentido ainda, quando admitimos que aquela preocupação expressa por ele no começo da aula era uma explicitação de sua desconfiança de que algo que lhe fugia o controle no grupo. Dizemos assim, que estando o professor preocupado com os alunos ele passou a intervir virtualmente a fim de descobrir o que estava ocorrendo. Como conseqüência, os alunos reagiram codificando a comunicação entre eles. 
Ainda no episódio 14.5, vemos que o grupo sofreu uma fragmentação cuja causa atribuímos a essa intervenção virtual. Assim, de um lado estavam Alan e Leandro e do outro Tim e Gomes. Os dois primeiros demonstravam mais disposição em resolver os exercícios de Física, enquanto que os outros dois não pareciam tão preocupados assim, demonstrando que estavam tratando da outra tarefa do grupo: passar o tempo.

É possível entender essa fragmentação como mais uma estratégia dos alunos em manter escondido o que de fato eles assumiram como tarefa, sobre tudo Tim e Gomes. Alan, que assumira o pedido do professor, se juntou com Leandro para tentar dar conta dos exercícios. Estes eram os que não tinham notas boas em Física. Já os outros dois, que tinham notas boas, se juntaram para passar o tempo. Parece-nos razoável pensar que o grupo mostrava (ao professor), através dessa configuração, que resolviam o que lhes havia pedido e ao mesmo tempo cumpriam a tarefa que assumiram para si.

O silêncio que se formava no grupo era bem comum, sendo quebrado por algumas poucas interações entre os alunos durante as vezes em que resolviam algum exercício. Isso se torna significativo ao percebemos que os alunos procediam assim quando (quase sempre) estavam envolvidos com a atividade do professor e não a tarefa deles. O sentido para tal feito pode ser uma tentativa deles de manterem em sigilo a respeito da tarefa deles.

Um das poucas discussões entre os alunos ocorreu no final do episódio 14.5 quando Alan, Leandro e Gomes discutiam sobre quantos zeros tem um milhão. Porém, o que nos chama a atenção é a presença de Gomes no subgrupo Alan-Leandro e a sua paciência para com o primo, Leandro, ao explicar-lhe o que não havia entendido. Essa sua postura para com o primo é bem diferente da que ele tinha com Alan. Podemos evocar a interpretação que fizemos da aula 10, em que admitimos que esse zelo de Gomes para com Leandro, além de uma relação parental, expressava o zelo institucional pelo mesmo.

No episódio seguinte, 10.6, o professor saiu da virtualidade se fazendo presente no grupo, sem que inicialmente se estabelecesse uma interação presencial propriamente dita. Porém, aquelas mesmas perguntas que Alan fazia ao professor sobre notas e correções de exercícios no episódio 14.5, quando ele apenas passava pelo grupo, agora são respondidas. Parece mesmo que a preocupação de Alan era com a nota e por isso se mantivera quase toda aula tentando resolver os exercícios e chamando aquele que 
achava que poderia lhe ajudar, Gomes. Assim, quando o professor estava presente no grupo, aquela atuação ambígua de Alan era suspensa, pois o grupo não poderia cumprir a outra tarefa diante do professor.

A fala do professor para os alunos- "do jeito que vocês estudam não dá mesmo!"-pode nos indicar que, depois daquela sondagem, ele teria captado, de alguma forma, que o grupo não atuava de maneira a realizar os exercícios e quando o faziam, era por meio de decoreba de fórmulas com o interesse de utilizá-las para sair logo da aula. Ainda preocupado com o grupo, a intervenção do professor se concentrou não somente na resolução da atividade, mas em assuntos de interesse mais imediato ao grupo: a maneira mais eficaz de se estudar física.

Nesse momento em que o professor estava no grupo, caracterizou-se uma intervenção presencial propriamente dita: ele atendia os chamados que lhe faziam, atuando contratransferencialmente em relação aos alunos; assinalava-lhes o que estava ocorrendo em relação à resolução dos exercícios tanto os da aula quanto os mais gerais e buscava acalmá-los em relação à prova. Além disso, parece-nos que ao tratar do tema estudar física, o professor buscava elaborar com o grupo o que seria parte de sua tarefa implícita. Esta consistia em superar a ansiedade gerada pela iminência da prova. No entanto, após a sua saída, os alunos voltaram para a configuração anterior com a formação em subgrupos.

No episódio final, Leandro se torna o porta-voz ao revelar qual era o pacto que grupo estabelecera. Mais uma vez aqui houve um acoplamento dos papéis, pois este aluno tornou-se o líder da tarefa grupo. Esta era fingir que faziam os exercícios e driblar o professor. Com essa afirmação de Leandro, parece fazer mais sentido aquela nossa interpretação de que o grupo assumira outra tarefa, diferente da que o professor lhes deixou.

Alan, ao término da aula, ainda vivenciava o conflito de sua atuação ambígua, pois demonstrava interesse pela tarefa do professor e era rechaçado por Gomes. Este aluno foi quem encerrou a atividade do grupo e agiu tal como quem conferia autorização aos demais para proceder da mesma forma que ele. A aula acabou para eles antes dos outros grupos e antes mesmo do professor dispensá-los. Esse evento nos dá indícios para pensar que o professor não tinha controle sobre este grupo e que quem 
ocupava o seu lugar institucional era o próprio Gomes, tal como já dissemos na análise da aula 10.

Concluímos nesta análise que não houve aquele salto qualitativo, em relação à tarefa que o professor lhe outorgara, e tão pouco houve um sistema de comunicação difuso, o que indicaria fluidez na comunicação e na elaboração das ansiedades básicas de medo e de ataque. Isso se torna mais claro após a intervenção presencial do professor em que o grupo não reajustou a sua rede de comunicação, permanecendo na mesma configuração de subgrupos.

A explicitação da preocupação do professor no início da aula teria despertado os alunos para camuflarem ainda mais a tarefa deles de passar o tempo e como disse Leandro, de fingir que faziam alguma coisa. O professor ainda preocupado teria sondado os alunos a fim de captar o que eles estavam fazendo e, quando resolveu entrar no grupo não conseguiu promover um salto qualitativo. Logo, o grupo se manteve na pré-tarefa.

Por outro lado, quanto à execução da tarefa deles, o grupo vivenciou uma circulação de papéis e criação de estratégias distintas para cumpri-la. Poderíamos dizer que houve uma operatividade em relação a essa tarefa de passar o tempo juntos e que eles atingiram a fase da tarefa. A nossa conclusão desta aula é que, quanto mais resistiam à mudança que o professor desejava, mais se tornavam operativos em relação a sua tarefa de passar o tempo.

\section{4-Episódios: aula 17 (11/11/2004)}

\section{1-Momentos Iniciais}

O conteúdo sobre o qual os alunos discutiam nesta aula é sobre Mecânica Newtoniana, cujos temas específicos são quantidade de movimento e impulso de uma força.

O início da formação do grupo nesta aula foi marcada por uma relação dos alunos com o microfone posicionado entre eles. Primeiramente, Tim e Leandro simularam um show de rap, cantando algumas rimas deste gênero musical. Em seguida, Gomes simulou desligar o microfone; e por fim, Alan, ficava batendo o seu lápis no pedestal do aparelho, como na aula anterior, provocando assim um ruído que dificultava a captação do som. Essa sua atitude se repetiu com frequiência durante esta aula. 
O que mais aparentava estar insatisfeito com a presença da câmara e do aparato de pesquisa era Gomes. Ele permaneceu o tempo de todo de costas para a filmadora e diversas vezes durante a atividade fazia algum tipo de comentário sobre a pesquisa. Nos momentos em que Gomes parecia que se lembrava do microfone era quando Alan iniciava o bater do lápis no pedestal.

Superado aquele momento do show de rap surgiu entre os alunos, ainda neste momento inicial, a discussão de qual função cada um deveria assumir, e aquela que nenhum deles queria era a de Anotador, que começava a ser jogada de um para o outro. Devido a essa discussão, Alan e Tim se lembraram de um episódio antigo e cobraram de Gomes e Leandro um exercício que eles não fizeram. Mas a função de Anotador ficou para Alan, pois todos o forçaram a isto. Contudo, Leandro salientou que na próxima aula esta divisão seria feita por sorteio.

\section{2-Início da Atividade (0.06.20)}

Logo após a escolha das funções, Gomes e Alan iniciaram a atividade. Gomes já tinha o exercício que o professor havia preparado- diferentemente da aula 14 a atividade não era um conjunto de exercícios do livro. Ele lia para Alan enquanto este escrevia os dados na folha de resolução do grupo. Essa postura de Gomes era bem característica em toda a atividade não somente para a leitura do enunciado do exercício, mas também para a resolução do exercício, ou seja, Gomes ditava para o Anotador a resolução enquanto esses dois alunos faziam o exercício, os outros dois estavam dispersos envolvidos com outro assunto.

Durante este período inicial, o professor se aproximou do grupo uma vez e a reação dos alunos foi silenciar. Sua intervenção foi no sentido de pedir que cada um anotasse em seu caderno o enunciado do exercício para que tentassem resolver sozinhos em casa. Logo após a saída do professor, os alunos se mobilizaram para fazer o que ele havia solicitado.

Os alunos então se envolveram em uma discussão sobre o exercício, pois havia uma discordância de Alan a respeito do que Gomes lhe falara. O que observamos foi a entrada de Tim e Leandro nessa discussão: Tim também não concordava com Gomes e Leandro tentava explicar para Alan e Tim o que Gomes lhes havia dito. Contudo, Alan anotou o que Gomes lhe falou mesmo sem concordar com ele. A situação permaneceu assim até que Gomes percebeu que de fato havia algo de errado no que ele falava, 
mesmo sem detectar o seu erro. A reação de Alan foi imediata exclamando: "Eu to falando que tem algo de errado!”. Tim imediatamente chamou o professor para ajudálos.

Observamos ainda em alguns momentos a formação de subgrupos: Tim e Leandro, que oscilavam entre o trabalho e a dispersão com outros assuntos - nestes momentos de dispersão às vezes envolviam os outros também. No outro subgrupo, os dois alunos faziam a atividade: Gomes indicava o que Alan deveria escrever.

\section{3-À espera do professor (0.17.42)}

Enquanto esperavam o professor, os alunos se dispersaram até que Tim fez um comentário do qual se envergonhou, porque se lembrou de que tudo estava sendo gravado. Então ele falou diretamente ao microfone, pedindo desculpas ao professor. E nesse momento os alunos fizeram mais uma reclamação do microfone, sendo que Gomes o fazia com mais ênfase.

Passado esse momento, enquanto esperavam o professor, os alunos mais uma vez promoveram um show de "rap", onde Tim e Leandro eram os protagonistas. Alan e Gomes se deitaram em suas carteiras à espera do professor. Por fim, Tim fez uma reclamação da demora do professor.

\section{4-Passagem do professor pelo grupo (0.21.35)}

Quando o professor chegou ao grupo todos comemoraram, mas quem tomou a iniciativa de falar com o professor foi o Tim, explicando-lhe a dúvida do grupo. Enquanto o professor ia explicando, Gomes ouvia atentamente. À medida que o professor falava, Alan comemorava, pois era o que ele tinha falado e Gomes aceitara. Leandro também interagia com o professor. Logo em seguida, o professor se retirou do grupo.

\section{5-Saída do professor $(0.22 .40)$}

Após a saída do professor, Leandro e Tim releram o exercício que era o motivo da dúvida deles, mas não demorou muito, Leandro levou outro assunto para o grupo e todos se envolveram com ele.

Quem chamou os alunos para voltarem para o exercício foi Tim:

Tim- Coloca aí, quantidade é a massa vezes a velocidade ... coloca aí! 
Tim oscilava entre esses momentos de dedicação ao exercício e de dispersão, pois ele sempre iniciava o seu show de rap. A configuração do grupo a partir daí era da seguinte maneira: Tim fazia os exercícios em alguns momentos e tentava ainda interagir com os seus colegas, lendo em voz alta para que eles o escutassem e também exercia a função do Anotador, que estava atribuída ao Alan. Concomitantemente, Gomes nada falava, mas resolvia o exercício em seu caderno e pouco interagia com outros alunos, nem mesmo quando era solicitado, por exemplo, por Tim que sempre tentava mostrar ao colega o seu resultado.

Uma situação concorrente a esta é a de silêncio que ocorria entre os alunos, que se caracterizava por estarem ou resolvendo cada um o seu ou detraídos com outras coisas. Esse silêncio era quebrado quando Tim se comunicava com Gomes ou quando ele chamava o professor, que sempre passava por perto do grupo, nas vezes em que ele não conseguia o retorno do colega.

Outro evento recorrente naqueles momentos de silêncio era o "ataque" de Alan à pesquisa, golpeando o pedestal do microfone ora com o lápis, ora com o pé. Ele permanecia batendo até que se cansasse ou esquecesse. E depois de algum tempo iniciava a sua empreitada.

\section{6-Professor no grupo $(\mathbf{0 . 3 0 . 0 0})$}

Como foi Tim quem chamou o professor, foi ele quem primeiro lhe dirigiu a palavra. Leandro tentava interromper nas vezes cruzando a conversa dos dois com algumas respostas truncadas às perguntas feitas ao outro colega. Contudo o que Leandro falava não era considerado pelos dois.

Tim- Eu tô fazendo assim ó: eu peguei o impulso que foi...(falava ao professor)

Leandro- ...que foi ...velocidade inicial vezes... terminal...(tentava cruzar a conversa)

Tim- ...que é igual " $q$ " final menos " $q$ " inicial...

O que seguiu após este episódio foi a formação de dois subgrupos: Tim e o professor, que tentavam resolver o que estava errado; e os outros alunos, Gomes, Leandro e Alan. A situação durou até que Gomes anunciou que haviam conseguido a resposta e daí em diante, o professor passou a interagir com todos no grupo e os ajudou na resolução do problema em questão. 


\section{7-Professor se retira do grupo $(0.32 .20)$}

Assim que o professor saiu do grupo o enquadre que se estabeleceu foi de silêncio, ou seja, não havia interação entre eles, no sentido da realização da atividade, o que não significava necessariamente que eles estavam dispersos . Em seguida, esse silêncio foi quebrado quando Leandro chamou Tim para conversar envolvendo os demais e iniciando um momento de dispersão que logo gerou uma outra situação de subgrupos: Tim- Leandro e Alan- Gomes. Os dois primeiros conversavam sobre outros assuntos e os outros dois resolviam o exercício: como antes, Gomes falava para Alan o que deveria ser escrito. A coexistência destes dois subgrupos permaneceu por um tempo considerável. Em alguns momentos Tim e Leandro ficavam algumas vezes quietos observando os outros dois, mas logo voltavam a conversar.

\section{8-Dissociação dos subgrupos (0.39.47)}

Em dado momento, Tim resolveu entrar no processo de resolução dos outros dois, ao ler o enunciado do exercício que Gomes e Alan estavam resolvendo, e dando ênfase para a palavra "energia cinética", começou a perguntar:

Tim- O que é energia cinética?

(Silêncio)

Gomes- Energia cinética?(Gomes então relê o exercício para Alan e não responde ao Tim)

Tim- Ou, como era a fórmula de Torricelli mesmo? ... do começo do ano!?!

Gomes- Você não lembra?

Alan-Velocidade ao quadrado...

Gomes interrompeu Alan e falou o restante da equação matemática de Torricelli. Porém, Tim não acreditou nele e procurou no livro a confirmação da reposta que o colega lhe deu. Com isso voltou a situação de subgrupos tal como minutos antes. Neste meio tempo Alan falou:

Alan- $O$ que vamos fazer agora?

Gomes indicou então o exercício que deveria ser feito o qual envolvia a noção de energia cinética e por este motivo Tim insistiu:

Tim- $O$ que é a energia cinética que não lembro? (ele pergunta isto enquanto procura no livro)

Alan e Gomes tentaram esboçar uma reposta para Tim, mas o grupo logo se dispersou novamente, pois outros assuntos eram concorrentes mais fortes do que a 
explicação da energia cinética e todos os alunos se envolveram com eles, com a exceção de Gomes que oscilava entre exercício e dispersão. Passados estes momentos o grupo passou por mais um momento de silêncio.

\section{9-“Ataque” ao pesquisador (0.43.00)}

Num dado momento, Leandro fez um comentário sobre o pesquisador, que foi advertido por Gomes devido à presença do microfone e da filmadora entre eles. Então, Leandro olhou para a filmadora por uns instantes, parecendo estar encarando-a e depois retornou a conversar com o colega.

Passados alguns minutos, surgiu no grupo uma dúvida sobre a unidade da energia cinética. Alan deu a resposta correta, mas ninguém acreditou nele e então resolveram perguntar ao pesquisador, que estava localizado próximo ao grupo. Ele confirmou a resposta do outro aluno. Em seguida, os alunos continuaram falando do pesquisador e se voltaram para o microfone e começaram a falar como se estivesse conversando com o pesquisador por meio do aparelho.

O grupo então se dividiu da seguinte forma: Gomes resolvia o exercício, e os demais dispersos com outros assuntos. Este quadro permaneceu até que o professor chegasse novamente ao grupo.

\subsection{0-Passagem do professor pelo grupo $(0.49 .15)$}

Esta é a primeira vez que o professor foi até o grupo sem que fosse chamado pelos alunos. Ao chegar, ele perguntou ao grupo:

Prof.- E aí, onde vocês estão?

Tim- Na ... " $h$ ” (se referindo ao item do exercício)

(Silêncio)

Tim- Como assim velocidade relativa entre os dois corpos? (faz esta pergunta ao professor)

A partir deste diálogo inicial, Leandro teve uma participação mais ativa perguntando e respondendo ao professor e aos colegas. Tim e Alan também se envolveram na discussão com o professor enquanto Gomes se manteve fazendo o seu exercício de forma independente e não participou desse momento, mesmo com o professor entre eles.

Nesse ínterim, surgiu o assunto sobre fórmula 1 que tinha uma relação com o tema do exercício. O professor se aproveitou dele para fazer algumas explicações e logo 
saiu do grupo. Porém, Tim e Leandro ficaram mais entusiasmados com o assunto e continuaram conversando sobre ele. E o que se observou foi, mais uma vez, a configuração de subgrupos: Tim-Leandro, conversando sobre o fórmula 1; Alan-Gomes, resolvendo os seus exercícios, de forma independente um do outro. A interação que ocorria entre estes era quando Gomes entregava a sua resolução para que Alan, como Anotador, a registrasse na folha do grupo.

Essa configuração ainda foi caracterizada pelo silêncio, de todos eles, até que Gomes falou para Tim:

Gomes- Fala com o professor que nós já quase acabamos, só falta terminar a ultima.

(Silêncio)

Gomes- Acabou, né, Alan?

Tim- Vamo cair fora! Vamo da fuga

E em clima de descontração Gomes chamou o professor:

Gomes- Professor, acabamos!

\subsection{1-Momentos finais: idas e vindas do professor $(\mathbf{0 . 5 9 . 3 0})$}

O professor foi até o grupo para fazer uma verificação dos exercícios. O que aconteceu foi que ele apontou um pequeno erro para Gomes, que logo em seguida se juntou com Alan para tentar resolvê-lo. E mais uma vez, os alunos estavam divididos naqueles subgrupos anteriores (Tim- Leandro e Gomes- Alan).

Quando os alunos pensaram que tinham encerrado a atividade, chamaram o professor para se certificarem que estava tudo correto, mas este logo notou algo no exercício que não lhe parecia correto:

Prof- a energia cinética mudou, né?

Alan- mudou... um pouco mas mudou

(Explicação do professor)

Prof- Mas a energia aumentou?

Alan- Aumentou, por que, teria que diminuir?

$\mathrm{O}$ professor interagia mais com Alan e Gomes, Tim às vezes se apresentava e às vezes fazia algumas operações matemáticas que o exercício pedia enquanto Leandro observava todos. E quando o erro foi finalmente identificado, o professor mais vez deixou o grupo e Gomes e Alan assumiram a resolução. 
Antes que eles terminassem de fazer as correções, o professor indicou (para todos os alunos da turma) que entregaria mais outra folha de exercícios que deveria ser feita em casa. Como conseqüência, se desencadearam os comentários a seguir:

Gomes- Ele vai trazer outra folhinha para nós! (olhou no relógio)

Tim- Ahaha! (fingiu rir) Mato ele!

(Gomes atira a folha de resolução do grupo para Tim)

Gomes- Pode levar!

Tim- Não quero!

Leandro- Ou! Vamos dormir todo mundo! (Fala repentinamente)

Alan-Vamos encostar a cabeça aí tudo mundo!

Tim- Quando o professor vier entregar, vai estar todo mundo dormindo (falou rindo)

Todos concordaram com o Leandro e deitaram sobre as suas carteiras e ficaram assim. Tim, não se agüentando de curiosidade, olhou para ver onde o professor estava e disse:

Tim- Ó, o professor viu!

(Professor chega ao grupo)

Prof- Ó, para vocês aqui! ... Uma tarefa para casa (ignorou o fato de que todos estavam "dormindo")

Todos resmungaram enquanto iam se levantando como se estivessem acordando depois de um cochilo.

Prof- Tenta resolver em casa. O terceiro item é uma atividade que vocês vão me entregar na próxima aula (...) Isto vai ser valendo ponto para a prova! ...

Prof- Só que vocês perceberam que não adianta fazer este exercício aqui ... copiando e depois tira nota na prova... tem que tentar entender para depois conseguir fazer outra coisa. Vou entregar esta folha aqui para vocês!

Alan- É para fazer em dupla

Prof- Não, individual!

Alan -Ah! Professor! ... A gente fica até mais tarde aqui pra todo mundo... (tentar resolver-fala provável dele para Gomes)

Tim- Me dá o meu aí! (fala ao professor)

Alan- Ô Gomes, a gente fica depois da aula para tentar fazer em dupla! (não obteve resposta do colega)

Tim- Professor! Professor! Uma para mim, professor!

Gomes- Não, é um para dois!

Prof- Só tem duas!

Gomes- Ah! Só tem dois! 
Alan- Depois da aula nós faz em grupo (insistiu com todos os seus colegas, mas ninguém the respondeu)

Prof- Copia! ... é o dois e o três ... copia ou ... sugiro que para vocês estudarem para a prova façam o um também! (comentou sobre os exercícios que ele estava entregando. Como só tinha duas folhas, alguém teria que copiar os enunciados)

Alan- Ô Gomes, vai copiar? (mostrou-lhe a folha com exercícios) Dá pra gente fazer em dupla também... depois da aula, uns cinco minutos... (guardou uma cópia com ele)

Como resposta Gomes apenas indicou com a cabeça que não.

Tim- Professor, deixa nós saí aí!

Alan- Prof, posso comer meu lanchinho?

Tim- Professor, deixa nós saí aî! Em professor, deixa nós saí.

À medida que ele insistia, ia se levantando, o que incentiva os outros também a fazerem o mesmo. Quando começaram a sair da configuração de grupo, ainda sem a autorização do professor, Leandro, ao passar pelo microfone o desligou, feito que teve a aprovação de Gomes. Os alunos do grupo 2 foram os únicos que se dispersaram pela sala antes da aula acabar. Além disso, a filmagem ficou sem som por alguns minutos.

\subsection{1-Análise da aula 17}

Esta aula é a terceira que analisamos, em uma seqüência cronológica, cujas datas estão indicadas no início das descrições dos episódios. A aula 17 ocorreu quase no fim do ano letivo, o que nos autoriza a pensá-la como um encerramento, como uma etapa final de um processo que o grupo vivenciou. Ou seja, buscamos interpretar os fatos da presente aula relacionando-os com um todo, que nos possibilita uma coerência na história do G2 ao longo do ano letivo.

A nossa interpretação das aulas anteriores pode ser reforçada aqui. Dissemos que o grupo 2 se configurou como um grupo de resistência à mudança e, por conseguinte, ao professor por ser o agente desta mudança. Também dissemos que os alunos assumiram outra tarefa para si: passar o tempo juntos. Nesta aula, essa mesma característica se manteve: o grupo estava reunido para realizar a sua tarefa e não a que o professor lhes pediu.

Logo no início da aula, vemos que havia uma relação diferente dos alunos com o microfone. Isso teria ocorrido, possivelmente, porque o aparelho estava posicionado 
entre os alunos, de forma mais invasiva, no centro do grupo enquanto que nas aulas anteriores sempre se encontrava num lugar mais periférico ao grupo.

A relação entre os alunos e o microfone se deu essencialmente de três maneiras:

- como forma de passar o tempo;

- como forma de "atacar" a pesquisa;

- como forma de se relacionar com o professor (ou com o pesquisador).

Quanto a primeira que destacamos, a forma mais evidente e recorrente era promovendo as apresentações de rap, tendo seus principais artistas Tim e Leandro.

Se admitirmos a hipótese de que o grupo tem um "segredo", que de alguma forma está relacionado à instituição por causa de Gomes que a representa no grupo e que também está relacionado à outra tarefa do grupo, sobre a qual o professor não poderia saber, o "ataque" a pesquisa e ao pesquisador ocorreu por se sentirem ameaçados com a presença do microfone tão dentro do grupo. Durante a aula o desligaliga do aparelho foi freqüente e no final da aula Leandro o desligou deixando-o assim, fato que só foi percebido pelo pesquisador posteriormente ao assistir o vídeo.

Essa atitude dos alunos que estamos chamando de ataque, ainda pôde ser percebida nas vezes em que Alan golpeava o pedestal do microfone, tendo sido muito recorrente ao longo da aula. É bem verdade que na aula 14 isso já acontecia, o que nos indica que essa relação com o microfone (e com a pesquisa) não é novidade desta aula, tornando-se apenas mais intensa.

Já no episódio 17.1, percebemos a articulação dos alunos entre si, como na aula anterior, para o "ataque" ao microfone: nos momentos de pausa dos shows da rap, Gomes ameaçava a desligar o aparelho, Alan seguia com sua empreitada de golpear ora com o lápis, ora com seu pé o pedestal em que estava suportado o microfone, dificultando assim a captação do som.

Tal articulação entre eles pode ser considerada como uma configuração grupal organizada e operativa, pois havia uma complementação dos papéis e formação de estratégias para a realização desse feito, que são características dos vetores de pertinência e cooperação. $O$ grupo vivia uma ambigüidade que se tornou uma característica dos seus alunos nesta aula, pois eles oscilavam entre a realização de sua tarefa e a resistência da atividade do professor. 
Se por um lado os alunos se articulavam para a realização da tarefa deles, por outro, ainda no episódio 17.1, percebemos que eles também se articularam para discutir sobre a função que cada um deveria exercer. Vemos, novamente, que as funções têm um aspecto normativo, que direciona as primeiras discussões do grupo para a execução da atividade que o professor lhes deixou. É interessante notar como eles percebiam cada função, por exemplo, o Anotador era a que menos gostavam de assumir, porque em sua concepção esta era a única em que de fato se trabalhava; ainda na visão deles, o Líder mandava e os Questionadores não tinham que fazer muita coisa, senão nada.

A partir da divisão das funções, iniciou-se um período de realização do exercício proposto pelo professor, sendo os mais atuantes Alan e Gomes. Este assumiu o papel de líder autocrático, que o seu colega aceitou, passando a atuar sujeito aos comandos dele. Essa sua postura para com Alan e às vezes para com o grupo ocorreu em diversos momentos desta aula: Gomes ditava o que o colega deveria escrever na folha do grupo.

A relação entre esses dois alunos, Gomes e Alan, era diferente da aula 14, quando o primeiro rechaçava o colega sempre que era solicitado. Uma possível explicação era a posição diferenciada que Alan ocupava no grupo nesta aula (17). Aqui ele não atuava como depositário daquela preocupação do professor e, portanto não era visto por Gomes como sabotador da tarefa do grupo. A aceitação da liderança autocrática pode ainda indicar uma tentativa de não reviver aquela experiência da aula 14. Contudo, não podemos afirmar completamente isso, pois entre as aulas 14 e 17 ocorreram outras duas sobre as quais não temos informações precisas.

O início da atividade de grupo (episódio 17.2) é marcado por uma intervenção institucional do professor, ao solicitar que cada um copiasse em seu caderno o enunciado do exercício que deveria ser feito em grupo durante a aula. Contudo, damos destaque para a reação dos alunos devido à chegada do professor no grupo, que foi silenciar. Essa postura dos estudantes é algo muito recorrente, sobretudo nesta aula, o que nos indica ser um emergente do grupo, justamente por ser algo repetitivo. Isso nos dá margem para pensar que o silêncio nos parece um código de comunicação dos alunos, cujo sentido é não revelar ao professor o que eles estão (ou não) fazendo. É possível pensar assim, mesmo com a presença da filmadora, que revelaria tudo, porque havia momentos em que eles se esqueciam da presença do aparelho (episódio 17.3). 
Quando observamos a forma como o professor fez as suas primeiras intervenções nas três aulas notamos uma recorrência, a intervenção institucional. A primeira aula foi marcada pela fala do professor, "o grupo do Gomes!"; a seguinte ele se apresenta ao grupo dizendo, "estou preocupado com vocês!". Nesta, o professor se aproximou pedindo que cada um copiasse em seu caderno a questão que tinha que ser resolvida em grupo, para depois tentarem resolver novamente sozinhos, dando assim o caráter institucional à sua intervenção.

O professor, ao atuar assim nas três aulas, não conseguiu promover os saltos qualitativos para que o grupo iniciasse um processo de mudança para a fase da tarefa. Uma das causas pode estar no fato de Gomes cumprir algumas vezes esse papel institucional dentro do grupo, como quem ocupava o lugar do professor, encontrando ressonância entre os alunos na maioria das vezes. Gomes nesses momentos assumia a liderança do grupo, ainda que à moda dele, e os alunos aceitavam desde suas falas em relação aos exercícios até a autorização do encerramento da atividade. Isso funcionou como um obstáculo ao processo de mudança do grupo.

No entanto, aquela primeira intervenção do professor no grupo nesta aula, nos parece que teve um desfecho diferenciado em relação às outras. Os alunos acataram o seu pedido e iniciaram a resolução do exercício, o que gerou um momento de discussão em torno do mesmo. Isso nos indica que de certa forma aquela intervenção institucional foi capaz de mobilizar os alunos para a resolução dos exercícios. Vimos então, os alunos se deslocarem de sua tarefa de passar o tempo, para atender ao pedido do professor, o que por outro lado, poderia significar uma forma de eles não revelarem ao professor que possuíam outra tarefa. Ou ainda, resolver o exercício teria se tornado outra forma de passar o tempo.

A relação entre os alunos enquanto discutiam o exercício foi tal que Gomes ainda atuava como líder autocrático, e os demais se tornavam depositários dessa liderança, pois mesmo discordando de Gomes, Alan escrevia na folha do grupo o que ele lhe dizia; Tim e Leandro não atuavam nas suas funções de Questionadores e aceitavam o que Gomes colocava para grupo. Podemos inferir disso, que Gomes representava no grupo a instituição e de alguma forma, representava também o próprio professor, já que este também tinha uma função institucional junto aos alunos. Encontramos nesse fato uma explicação do porque eles se tornaram o grupo da resistência, ao professor e a tarefa: estes competiam com Gomes e com a tarefa 
escolhida pelo grupo. E ainda, podemos dizer que Gomes se tornou o líder da resistência à tarefa e ao professor.

Uma conclusão imediata desse evento é que as funções não foram compreendidas pelos alunos como esperávamos, dando a entender que o uso delas como recurso normativo, por si só, não garante o interjogo de papéis. O seu sucesso depende de outros fatores como o vínculo entre os membros, a história do grupo, de fatores externos (instituição) e a relação com o professor.

Mesmo assim, nos momentos em que o grupo discutia, encontramos situações em que a configuração gerada era de um sistema de comunicação difusa, quando ocorria uma fluidez da comunicação e a circulação dos papéis, como no episódio 17.2. Porém, após um tempo assim funcionando, o grupo esbarrou numa dúvida no exercício interrompendo esse sistema difuso e chamaram o professor. Ao esperá-lo, ocuparam-se de passar o tempo. Em contra partida, chamar o professor pode significar superar a liderança de Gomes, que atuava com autoridade no grupo, mesmo que estivessem experimentando aquela configuração. Essa atitude do grupo pode ser considerada em mais uma ambigüidade: a aceitação e a recusa da liderança de Gomes.

A terceira forma dos alunos se vincularem com o microfone foi utilizando-o como meio de se relacionarem com o professor. Logo no início de 17.3, Tim usava o microfone para pedir desculpas ao professor por algo que falou e que the parecia “pesado". Para os alunos, em especial Tim (e Gomes), o professor é representado pelo microfone, ou melhor, o professor é o microfone.

Assim, falar pelo microfone é falar com o professor, ainda mais, repudiar o aparelho (como Alan costumava fazer ao golpear o pedestal) é repudiar o professor que invade o grupo. Porém, logo em seguida ao evento acima, essa relação com o microfone mudou, e iniciava-se a apresentação de rap tendo Tim e Leandro como os artistas principais, o que conferia uma vez mais o caráter de ambíguo ao grupo.

No episódio 17.4 o professor fez uma passagem rápida não se caracterizando numa intervenção presencial propriamente dita. Ele permaneceu o tempo de responder uma dúvida, que foi externada por Tim, e em seguida saiu. E tal como ocorreu em 17.2, os alunos tiveram um envolvimento com o exercício, que não foi duradouro. De uma maneira geral, o professor pouco ia ao grupo e quando aí estava, permanecia pouco tempo (vide minutagem ao lado dos títulos dos episódios). 
No episódio 17.5 notamos que Tim tem uma participação que nos parece ambígua, tornando-se o porta-voz do comportamento ambíguo do grupo. Nesse episódio, e algumas outras situações desta aula, ora ele se direcionava para a resolução dos exercícios- quando isso ocorria, em geral, era ele quem chamava o grupo para resolução-, ora ele atuava como rapper, promovendo suas apresentações, envolvendo os demais colegas.

Essa ambigüidade nos parece ter alguma semelhança com aquela que Alan vivenciava na aula 14. Naquela situação ele estava preocupado em atender a demanda do professor e do grupo, ao mesmo tempo. No caso de Tim essa ocorrência é semelhante se pensamos que fazia o mesmo movimento de Alan, oscilando entre atender o professor e o grupo. E ainda, quando nos atentamos para a relação de Gomes e Tim, percebemos uma semelhança com aquela que Gomes tinha com Alan na aula 14, de rechaço, como nos episódios 17.5 (e 17.8).

Por outro lado, podemos inferir que Tim estava somente passando o tempo e a resolução do exercício seria parte dessa atividade. Isso pode indicar que o grupo estaria encarando a atividade do professor de forma semelhante a Tim.

Ainda no episódio 17.5, o silêncio gerado pelo grupo pode caracterizar uma estratégia de resistência do grupo e uma forma de manutenção do seu segredo. Ou seja, não se comunicar verbalmente poderia ajudar a manter em sigilo que os alunos haviam assumido outra tarefa. Nesse mesmo sentido, o silêncio de Gomes diante de Alan, na aula 14 e de Tim nesta aula pode conter o mesmo significado, uma vez que ele atuava como o líder da resistência.

A resistência de Gomes pode ser observada também pela sua disposição física no grupo, pois nas duas aulas (14 e 17) ele se encontrava de lado para os colegas, enquanto todos estavam um de frente para o outro e de costas para a filmadora. E, diferentemente dos outros alunos, Gomes não parecia atuar no grupo segundo uma ambigüidade, como os outros alunos, pois para ele havia uma só tarefa.

Ao analisarmos o episódio 17.6, vemos que a atuação de Leandro não era diferente das outras aulas, nas vezes em que o professor estava no grupo. Nesses momentos, era como se estivesse tentando dizer ou mostrar para o professor e para o grupo que ele também podia ajudar na resolução do exercício, que ele estava presente 
no grupo, numa tentativa de se incluir. Esses ocorridos se caracterizam como mais um emergente do grupo.

Recordamos a nossa interpretação da aula 10 sobre a relação de Leandro e a instituição para nos ajudar a compreender aquelas situações. Ele fora acolhido pela escola, numa tentativa de ser ajudado, pois vinha apresentando um mau histórico escolar onde estudava antes. Porém, ele não correspondia, aparentemente, a essas expectativas que lhe foram depositadas, tendo repetido a série em que estava ( $1^{\mathrm{a}}$ do Ensino Médio) e mesmo naquele ano não tinha um bom rendimento escolar, e não apresentava indícios de melhoras.

O comportamento de Leandro diante do professor quando ele ia ao grupo é no sentido de tentar mostrá-lo que está ali e pode contribuir. O professor ainda revelou em conversas informais com o pesquisador que ele sempre buscava conversar com este aluno para tentar extrair alguma informação a fim de auxiliá-lo, mas que somente ficou sabendo que o aluno sentia dor de cabeça durante as aulas. Isso justifica os vários momentos que esse aluno se encontrava prostrado em sua mesa na sala. Também em conversas informais com a diretora da escola foi possível detectar a sua insatisfação diante do rendimento de Leandro. Ela dizia que não sabia como proceder nesse caso, visto que tinha um complicador a mais que era o vínculo familiar.

Leandro, diante de tantas pressões, parecia assumir o papel de porta-voz de algo que é o "sinal de um processo grupal, que até esse momento permanecera latente, como escondido no interior da totalidade do grupo" (PICHON-RIVIÈRE, 2005, p.257). O grupo pode ser entendido aqui também a instituição de quem se torna depositário de uma demanda de sucesso.

Esse algo que Leandro anunciava ao professor é o tipo de vínculo que se estabelecia entre os membros do grupo e ele:

- $\quad$ seja de fragmentação (vide aula 10);

- seja de amparo sobre ele, isto é, o grupo reproduzia sobre ele os "sentimentos" da instituição;

- seja na atribuição do papel de bode-expiatório como forma de incluí-lo no grupo (vide aula 14);

- seja de depositário da demanda de sucesso. 
No episódio 17.8, Tim teve a iniciativa de resolver o exercício e tentou abrir canais de comunicação com o subgrupo Alan-Gomes, que estavam direcionados para o mesmo exercício. E como já apontamos, a reação de Gomes foi de rechaçar o colega. Podemos pensar em algumas possíveis causas para essa reação de Gomes:

- Como ele tinha um domínio maior do conteúdo em relação aos demais, então é como se ele pensasse da seguinte forma: "Eles não sabem nada, não estudam e ficam aqui me pedindo para explicar-lhes tudo! Eu não sou obrigado a ajudá-los!"

- Resolver a atividade em grupo significava se expor diante da filmadora, o que poderia revelar os tais "segredos" do grupo, que como já apontamos., Em última instância, são os segredos da instituição. Nesse sentido é que Gomes não ajudava os colegas, com exceção de Leandro, que era ajudado pela escola, logo por Gomes também.

Em 17.9, temos o que chamamos de "ataque" ao pesquisador, pois Leandro fazia comentários nesse sentido e que prontamente fora advertido por Gomes sobre a presença da filmadora. Em seguida, os alunos mais uma vez se relacionaram com o microfone como se estivesse falando com o pesquisador, ainda que em tom de "ataque", portanto, dizemos que nesse momento o microfone para o grupo é o próprio pesquisador com quem conversavam e se relacionavam. Nesse sentido foi possível dar um significado a outro emergente do grupo: os golpes com os pés e lápis no pedestal do microfone. Se tal aparato é o professor ou o pesquisador, trata-se de um intruso no grupo, alguém que não deveria estar ali, porque para eles atuaria como um denunciante do que ocorria no grupo.

No episódio seguinte, 17.10, o professor, pela primeira vez, se aproximou do grupo sem ter sido chamado pelos alunos, intervindo de forma institucional. Tim lhe respondeu e depois todos se silenciaram. Entendemos que esse silêncio ocorreu porque o grupo atuava na outra tarefa, e assim não podiam responder diretamente ao professor que parte do exercício eles estavam fazendo e tão pouco podiam dizer que não faziam o que lhes fora solicitado.

Na sequiência, Tim conseguiu responder ao professor e, após o momento de silêncio, iniciou uma conversa com ele. Contudo, nos parece mais uma estratégia de Tim para não deixar transparecer que o grupo não resolvia os exercícios do que 
interesse em sanar a alguma dúvida. Afirmamos isso com base em alguns outros momentos do grupo, por exemplo, nas vezes em que o professor se aproximava dos alunos quando Tim promovia seus shows de rap em que, ou ele iniciava uma conversa com o professor sobre o exercício, simulando uma dúvida, ou então simplesmente parava de cantar e se voltava para o caderno, fingindo resolver os exercícios.

O fato que nos pareceu mais marcante desta aula ocorreu no episódio 17.11, já nos momentos finais, quando Leandro propôs ao grupo outra forma de passar o tempo, dizendo aos colegas: "Vamos dormir todo mundo!". Observando o contexto em que surge essa fala repentina de Leandro na conversa entre eles, percebemos que fazia parte de um tema geral que os alunos tratavam: eles buscavam uma forma de não fazer mais uma tarefa que o professor lhe pedira. Então, Leandro é extremamente criativo ao propor que todos fingissem que estavam dormindo e torna-se um líder do grupo, ao ter a sua idéia rapidamente aceita e executada. Isto é, tornou-se líder ao considerarmos a tarefa dos alunos e não a do professor.

Parece-nos interessante o movimento que Leandro tem no grupo ao olharmos as três aulas: na primeira vimos que tentava se envolver com os exercícios e como era tutorado por Gomes e ainda na primeira aula, atribuíram-lhe o papel de bodeexpiatório quando o grupo se justificou ao professor que não faziam a atividade porque esperavam pelo colega; na aula seguinte, ele não se demonstrava tão interessado pela resolução do exercício, mas quando o professor estava no grupo, ele tentava, segundo a nossa interpretação, chamar a sua atenção e no fim dessa mesma aula ele disse para que todos fingissem que estavam escrevendo e fazendo o exercício; na presente aula, ele atuava junto com Tim na promoção dos shows de rap e no fim propôs que todos dormissem para evitar que o professor não lhes deixasse nenhuma outra tarefa.

A trajetória de Leandro no grupo parece ser ambígua no sentido de que ora atuava porta-voz do grupo, explicitando a forma com o grupo se vinculava com ele, ora líder propondo ações para a tarefa do grupo. Ou seja, quando se tratava da atividade do professor ele não tinha presença marcante, mas para a tarefa de passar o tempo ele atuava como líder. E em uma análise mais geral, essa ambigüidade parece ser a sina do grupo.

A postura do professor diante da ação dos alunos "dormindo" também nos parece interessante, pois ele simplesmente ignorou tal fato e entregou-lhes mais um 
exercício que deveria ser feito em outro momento. Ademais, o que ele falou para os alunos nos dá a entender que ele percebeu que os alunos não fizeram quase nada do exercício desta aula -"Só que vocês perceberam que não adianta fazer este exercício aqui ... copiando e depois tirar nota na prova”. Nesse momento ele captou qual era a regra do grupo para resolver o exercício o que nos faz entender aquela sua preocupação, cuja causa não fora revelada naquela aula, senão agora.

Antes dos alunos desfazerem o grupo, Alan insistiu com Gomes para que resolvessem os dois juntos o novo exercício que o professor lhes deu. Diante disso, Gomes se portava da mesma forma que na aula 14, recusando firmemente o pedido de Alan, diferenciando-se de como se portara em relação ao colega durante a aula, quando chegaram a formar subgrupo para resolverem o exercício. A justificativa para essa postura de Gomes já foi descrita anteriormente.

Por fim, os alunos promoveram uma série de eventos indicando mais uma vez que eles não estavam reunidos para resolverem a tarefa do professor. As perguntas do Tim e Alan nos mostram claramente isso, bem como sua ação de ir deixando o grupo mesmo enquanto perguntavam. $\mathrm{O}$ grupo, então, terminou reforçando sua resistência ao professor e ao pesquisador e indicando quanto o professor não tinha o controle sobre eles. E quando Leandro desligou o microfone, sem ligá-lo novamente, explicitou a relação do grupo com a pesquisa. 
CAPÍTULO 6 


\section{6-CONSIDERAÇÕES FINAIS}

Em nosso trabalho fizemos uma análise de três grupos de uma mesma classe. Nossa primeira conclusão, e um tanto óbvia, é que os ambientes de ensino e aprendizagem são, naturalmente, marcados pela diversidade, independente da quantidade de alunos que a compõe. Particularmente, encontramos o grupo da mudança, da resistência e da dependência. A introdução dos trabalhos em grupos e sua investigação sistematizada evidenciaram esse aspecto de uma sala de aula.

Do total de aulas filmadas, analisamos sete, número considerado suficiente para os objetivos deste trabalho. Buscamos também selecioná-las tendo como marco de referência a instituição das funções, para bem avaliarmos os seus efeitos nos alunos e no professor. Essas proporcionaram uma diferenciação na atuação dos estudantes, percebida, por exemplo, no início de cada aula quando eles discutiam quem assumiria qual função, ainda que não as cumprissem corretamente; e também do professor, quando ele assumia alguma função a fim de ensinar-lhes como deveriam proceder.

Se de um lado temos as funções que modificaram a dinâmica das aulas, por outro, dissemos que a própria utilização dos grupos como recurso didático altera significativamente, por si só, a rotina de um ambiente de ensino-aprendizagem. Os desdobramentos do professor perante os alunos são diferenciados de quando atua de maneira expositiva ou atendendo individualmente seus alunos. Logo, entendemos que os objetivos do professor são deslocados para o processo grupal e para os alunos enquanto agentes deste processo.

A razão para essas diferenciações ocorre, pois durante uma intervenção nos pequenos grupos o professor está diante de uma pluralidade cujas ações psíquicas se distinguem das individuais (ANZIEU \& MARTIN, 1971). Essa afirmação, então, nos leva a pensar que o professor está sempre diante de uma pluralidade: a classe. Torna-se evidente que as ações do professor durante as suas aulas, para lidar com a diversidade aí existente, podem ser enriquecidas se em sua formação encontra-se o conhecimento sobre os grupos: trata-se de uma segunda conclusão de nosso trabalho.

Cada grupo investigado apresentou características bem peculiares, permitindonos uma discussão muito rica sobre o uso desses dispositivos nas aulas de Física, cujos fatores que consideramos mais importantes para os efeitos do processo são: o próprio 
grupo, enquanto organização; as intervenções do professor e as funções introduzidas para direcionar os trabalhos; e a tarefa explícita, que revelava a relação dos estudantes com o conhecimento Físico.

\section{1-Os grupos}

O grupo 3 apresentou uma mudança operativa, ou seja, os alunos apresentaram indícios de que saiam da fase da pré-tarefa. Foram características marcantes neste grupo o problema da liderança, o lugar do líder e a aspiração que todos tinham por ocupá-lo, cujas falas dos alunos e professor bem como os eventos ocorridos nos possibilitaram esta interpretação. A associação entre saber Física e assumir a liderança era outra marca deste grupo.

A aula 8 foi fortemente marcada pela liderança do professor e de Tito, a quem o grupo estava "de mão dadas" e por isso era ele que podia ocupar o lugar do líder. Tito se tornou o depositário da liderança, pois de um lado ele sabia Física (fazia o que todos não faziam) e por outro o professor o legitimou para assumir esse papel. Consideramos que esses eventos contribuíram para a permanência dos alunos na fase da pré-tarefa.

A presença de Hernam parece que perturbava a ordem já estabelecida pelos próprios alunos, o qual sofreu ataque dos colegas por indicar uma mudança na rotina do grupo e cuja adjudicação do papel de bode-expiatório era para que se mantivesse a liderança de Tito. Essa postura dos alunos nos mostra uma contradição, pois se de um lado eles aspiravam ao lugar do líder, por outro não queria que Tito o desocupasse. Após algumas intervenções do professor, a aula foi encerrada sem que os alunos resolvessem sua tarefa implícita, que era "soltar a mão de Tito".

Já na aula 13, a situação parece ter sido bem diferente, pois as funções introduziram uma nova rotina no grupo em que a principal conseqüência foi $a$ percepção por parte dos alunos que o lugar do líder poderia ser ocupado por outros. Desse forma, parece-nos que os alunos cortaram a árvore e iniciaram a construção da canoa: todos queriam estar no lugar do líder e buscavam fazê-lo se envolvendo com a resolução da atividade. Porém, ocupar esse lugar tinha uma exigência que era saber Física, e por este motivo dissemos que como efeito colateral dessa busca pela liderança, os alunos aprendiam Física, ou pelo menos se empenhavam para tal. E como 
mostramos, nos momentos finais da aula Ricardo havia assumido o papel de líder progressivo do grupo.

As nossas observações extra-filmagem nos mostraram que Valentim e Ricardo foram os que mais renderam com as atividades em grupo, pois os ouvimos dizer, com entusiasmo, em uma conversa com o professor durante a aula que suas notas haviam dobrado, mesmo que não estivesse dentro da média exigida pela escola. Certamente, não podemos afirmar categoricamente que esse rendimento dos alunos se deveu somente as atividades em grupo e a atribuição das funções, mas nos parece razoável estabelecer uma associação entre tais eventos.

$\mathrm{Na}$ aula 5 do grupo 1, em que houve uma apresentação das alunas sobre Segunda Lei de Newton, foi possível extrair informações importantes para a construção da análise do processo grupal, embora não corresponda à forma habitual adotada para as atividades. Apareceram nessa aula o papel de líder autocrático e laissez-faire, assumidos por Janaína.

No momento em que o grupo vivenciava o ataque da turma por não saber a resposta da pergunta do professor, o objeto de conhecimento, a Física, parecia-lhes totalmente hostil, e as ansiedades básicas passaram a operar. Ele, então, atuou como líder progressivo, ao conduzir o grupo para a saída do posição esquizoparanóide. Esse drama do grupo chegou ao fim de forma que os papéis estivessem estereotipados e dando indícios de ser um grupo da dependência, de Janaína e do professor.

A aula 12 foi muita extensa e de uma riqueza de informações sobre o grupo e suas relações interpessoais, cujo principal evento neste sentido foi a tensão estabelecida entre Rebeca e Camila. De um lado, Rebeca dava indícios de não querer depender tanto do professor, e do outro, Camila parecia reforçar que só o professor poderia auxiliá-las com os exercícios.

Mas antes desses eventos, Carmem se autodeclarou incapaz de resolver qualquer exercício e, talvez por conta disso, era quem mais propunha às demais colegas que chamassem o professor ou pesquisador para ajudá-las. Foi a partir desse momento inicial que admitimos que o segredo do grupo era o de não saber Física e somente o professor estava autorizado suprir essa demanda, por isso a dependência. Nas vezes em que Rebeca demonstrava romper, ao demonstrar ter um mínimo conhecimento sobre 
o conteúdo, o grupo não a aceitava e rechaçava todos os seus comentários, porque do contrário, deixariam de depender do professor.

A outra aula deste grupo $^{25}, 16$, foi usada somente para ampliar o nosso conhecimento sobre o grupo 1 e corroborar a nossa interpretação. Os principais eventos que ocorreram no grupo foram as vindas e idas do professor e a exclusão completa, inclusive por este, de Eugênia que era recém ingressa na escola. Por conta da constante presença do professor entre elas, o sentimento de desamparo, que haviam experimentado na aula 12 , não ocorrera e a telê era de muita alegria, com risos de tudo que acontecia.

O grupo da resistência foi o que mais nos chamou a atenção, pois os alunos seguiram para uma direção jamais por nós imaginada. Podemos dizer que o grupo experimentou uma mudança, mas não no sentido pichoneano, quando inferimos que $o s$ alunos assumiram outra tarefa para si que era passar o tempo juntos. A forma que encontraram para resolvê-la, por assim dizer, foi se tornando mais completa e sofisticada a cada aula, com atitudes criativas dos alunos, culminando nas apresentações de rap de Tim e Leandro.

Por outro lado, a presença de Gomes nos parece importante na trama do grupo 2, já que o próprio professor o nomeou como sendo deste aluno. A nossa interpretação consiste em atribuir a ele um papel institucional, dado a sua relação parental com os diretores e donos da escola. Um desses aspectos institucionais foi a transferência da missão que a escola tinha de zelar por Leandro que ele fizera para si. Na aula 10, esse processo se tornava mais claro quando ele pedia que o grupo esperasse por Leandro e quando, nessa mesma situação, se predispunha a explicar-lhe o exercício.

A conseqüência foi a resistência do grupo frente ao professor e a tarefa que ele lhes pedia, pois não podia haver no grupo outro representante da instituição, ou seja, Gomes assumia o lugar institucional de forma que as intervenções institucionais do professor não tinham efeito. Os sintomas eram a não aceitação das funções, ainda que isso ocorresse implicitamente, e o ataque à pesquisa e ao pesquisador.

A presença do aparato de pesquisa interrompia o grupo de passar o tempo juntos, sem fazer a tarefa do professor e ao mesmo tempo em que revelava os conflitos implícitos da instituição, que constituía o segredo de Gomes, e, por conseguinte, do

\footnotetext{
${ }^{25}$ Vide apêndice III.
} 
grupo. A estratégia que o grupo usava era o fingimento e a burla da tarefa do professor, como nos revelou Leandro nas aulas 14 e 17. O seu significado era manter-se estável com, cada qual com os seus papéis, e assegurar por outro lado a estabilidade do papel de Gomes como líder, quem cumpria o papel do professor.

O conflito de Gomes, por assim dizer, consistia no fato de que ele não podia não fazer os exercícios que o professor solicitava, mas também não podia fazê-los como ele gostaria. Numa inferência mais geral sobre Gomes dizemos que para ele aceitar o professor, e suas explicações, significava matar, em um sentido metafórico, o pai, que também era professor desta mesma disciplina. Logo, a Física tinha um valor simbólico mais forte, pois representava o seu pai.

Em suma, o grupo se manteve na pré-tarefa, tendo os papéis estereotipados e evitando a mudança oferecida pelo professor. Este por sua vez, evitava os conflitos com Gomes, e suas intervenções eram no sentido de uma manutenção do status quo da situação. Porém, o grupo se tornou operativo em sua tarefa de passar o tempo, com estratégias sofisticadas e criativas, cujo ápice foi na aula 17 quando Leandro propôs que todos dormissem e, ao fim da aula, desligou o microfone deixando-o assim até o fim da filmagem.

A partir dos episódios dos grupos, identificamos alguns eventos que são comuns nos três grupos, que são a assunção e adjudicação do papel do líder, a presença do novo e o atravessamento institucional nos grupos.

O papel do líder cumpre funções distintas dentro do grupo, podendo ter efeitos estruturantes, sugestivos ou organizadores enquanto que no campo do imaginário atua como sendo suporte de identificações, projeções e transferências de situações primárias de quem o torna depositário.

Nesse sentido, segundo uma concepção mais geral, a noção de líder é intrínseca ao grupo, ou seja, sempre quando um certo número de pessoas se reúnem, estarão sob a influência de um chefe: é como um rebanho que não poderia viver sem o seu senhor, pois possui o anseio de obediência. Ainda nessa perspectiva, o líder se faz notado por meio das idéias em que ele próprio acredita, por vezes, fanaticamente ${ }^{26}$. No pensamento

\footnotetext{
${ }^{26}$ Freud em "Psicologia dos grupos e análise do ego" cita Le Bon para então tecer seus comentários sobre os grupos. Ele inicia seu texto dizendo: "Em vez de partir de uma definição, parece mais proveitoso começar com alguma indicação do campo de ação dos fenômenos em exame e selecionar dentre eles
} 
de Lewin a atuação da liderança é um fator decisivo para a atmosfera do grupo, o qual poderá conduzir à solução dos conflitos (sociais) desde que adote um estilo favorável ao equilíbrio das tensões (SILVA, 2000).

Há nessa forma de pensar uma concepção dual, em que o líder surge em contraposição ao agrupamento (massa ou multidão) no qual os membros remetem seus interesses a ele; isto significa que o interesse do líder passa a ser o das pessoas reunidas em torno dele. Então, no líder, externo ao grupo, está depositado o ideal dos indivíduos que se unem em torno dessa personagem.

Na formulação pichoneana, o líder não é esse sujeito externo; ele está no interior do grupo, como um membro, cujo surgimento depende do momento vivenciado pelos sujeitos em situação; ele deve mudar dentro da organização grupal, promovendo estágios de mudança. O líder é alguém que se faz depositário dos aspectos positivos do grupo, tornando-se funcional para alavancá-lo nos momentos de conflitos, por isto é possível considerar que o professor também tinha o papel de líder atribuído pelos alunos.

Sobre a presença do novo na rotina do grupo, trata-se sempre um momento de ansiedade, no caso do grupo 3, quando Hernam estava nesta condição, os alunos lhe atribuíram o papel de bode-expiatório, como forma de se fecharem e manterem a liderança. Já com de Eugênia, novata no grupo 1, não foi permitida a sua participação, dado que isso significaria partilhar a cobertura que o professor lhes dava na aula 16. Os dois alunos que eram novos se encontraram na mesma situação: a exclusão.

Quando o grupo está diante de nova uma situação, isto implicará a exigência de uma adaptação ativa à realidade: uma reestruturação dos vínculos e das formas adaptativas dos sujeitos (PICHON-RIVIÈRE, 2005). Então, diante dessa exigência são disparadas as ansiedades básicas de medo e de ataque: "temor da perda dos vínculos anteriores e temor do ataque da nova situação, na qual o sujeito não se sente instrumentado" (ibid, p. 224). A exclusão, nos casos apresentados, transforma-se em um meio para evitar esse processo de mudança.

Contudo, a mudança é inevitável com a presença de um outro que se incide sobre uma rede de relações já estabelecida, porque este recém chegado projeta sobre os apresentada no parágrafo sobre o qual comentamos nesta nota e o seguinte, está nessa obra de Freud. 
demais suas fantasias inconscientes, transformando a si e o próprio grupo. A partir dessa idéia, torna-se possível pensar numa relação entre o professor e a classe já que ele pode atuar como esse elemento novo para este grupo-classe. Isso explicaria, ainda que de forma restrita, alguns conflitos que ocorrem entre esses sujeitos, culminando, algumas vezes, na rejeição do professor.

Por fim, identificamos o atravessamento institucional nos grupos, estando mais evidente no grupo2. Sobre isso encontramos uma referência que pode nos ser útil para entender melhor esse mecanismo:

"Os conflitos de ordem institucional transcendem de forma implícita, e aparecem como distorções do próprio ensino. Os conflitos não explicitados nem resolvidos no nível da organização institucional canalizam-se nos níveis mais inferiores, de tal maneira que o estudante se torna uma espécie de recipiente no qual os conflitos poderão cair ou causar impacto" (BLEGER, 2001, p. 67)

No grupo 2, Gomes era o depositário dos conflitos da instituição, que o levou a assumir um papel com o mesmo caráter, institucional, diante dos colegas e do professor, com quem competia para manter-se nesse papel. A demanda que estava sobre Gomes era zelar por Leandro, tal como a escola fazia e, portanto, este também possuía uma característica institucional. Leandro e Gomes formavam um subgrupo importante no grupo 2, cujo pacto era fingir, para que o professor pensasse que estavam cumprindo as atividades.

A indagação sobre os atravessamentos institucionais e sociais presentes no grupo se faz importante na compreensão das relações entre os sujeitos do processo grupal, que em nosso caso trata-se, fundamentalmente, da relação professor-aluno durante as aulas de Física. Essa relação é marcada também por formas de intervenções que se pretendem ser eficazes no manejo do processo de ensino-aprendizagem quando os seus atores (professor e alunos) estão assim reunidos.

Assumir que um grupo é perpassado por múltiplos atravessamentos implica uma negação do modelo que o trata como um mediador entre o individual e o coletivo. $\mathrm{O}$ modelo dual seria fruto de um "pensamento ocidental que costuma articular como lógicas binárias hierarquizantes antinomias tais como: material-ideal, alma-corpo, serter, objetivo-subjetivo, público-privado, as quais são abarcadas desde o ponto de vista da filosofia, da política e da ciência” (FERNADEZ, 2006, p.49). 
Então, podemos representar o nosso entendimento sobre o grupo como um sistema complexo, psíquico e social, cujos símbolos e códigos por seus membros partilhados devem ser re-significados na medida em que a verticalidade do sujeito cruza com a horizontalidade do grupo. Um possível modelo ilustrativo dos atravessamentos de vários níveis é apresentado na figura a seguir.

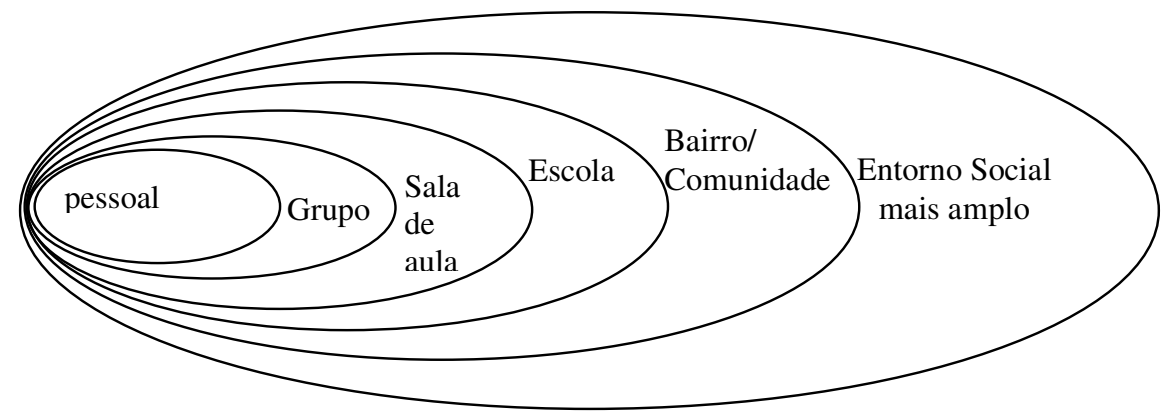

Fig. 20- As formas de grupalidade que foram descritas em termos daqueles níveis têm uma relação complexa entre si. O grupo não é necessariamente visto como uma mediação entre indivíduo e sociedade.

Como exemplo, podemos (re)pensar a sala de aula tendo como base esses elementos relacionais dos vários níveis, isto é, os alunos reunidos configuram uma forma de grupalidade que pode vir a ser um grupo primário ${ }^{27}$. Esta é parte de um grupo secundário, a Escola (Instituição), que estabelece normas e regras a serem seguidas, sendo que ela está imersa em um bairro ou comunidade que determina em certo sentido as suas regras (num caso de uma escola particular os pais podem exercer certo tipo de pressão, deixando-a condicionada aos seus interesses). Tudo isso está envolvido por um contexto social mais amplo, sujeitando a Escola às políticas do poder público, sendo mais direta essa relação para o caso de uma escola estatal (VALADARES, 2002).

\section{2-As intervenções: o professor e o pesquisador}

\subsection{1-O professor}

Consideramos como aspecto importante de nosso trabalho as intervenções do professor no processo dos grupos. Optamos por uma classificação destas ações a fim de nos auxiliar na análise, mas sabemos que os três tipos que destacamos não se esgotam em si mesmos, senão, nos ajudam a pensar na atuação do professor junto aos alunos em grupo.

\footnotetext{
${ }^{27}$ Sobre as formas de grupalidade, vide apêndice 2.
} 
Entendemos que o professor não está isento das múltiplas transferências que ocorrem no grupo, tornando-se ele membro interino. Assim sendo, as intervenções institucional, presencial e virtual dizem respeito à forma como o professor se faz presente no processo grupal dos alunos, obtendo deles reações diferenciadas para cada tipo de intervenção. Uma vez que o professor é uma figura essencial no processo de ensino-aprendizagem, analisar as suas ações e os efeitos torna-se fundamentalmente importante.

$\mathrm{Na}$ técnica terapêutica de grupos operativos, o coordenador tem a função estabelecer o enquadre do grupo - intervenção institucional - bem como sua manutenção, ao promover a comunicação entre os membros, assinalar e interpretar os eventos do grupo - intervenção presencial. Em outras palavras, quando o grupo se encontra naquele momento entre a não árvore e a não canoa, sente-se fragilizado e ameaçado por uma nova situação, o coordenador deve atuar no sentido de ajudá-los nessa passagem. A cura ocorre na medida em que os papéis são intercambiáveis entre os membros do grupo, como se deu no episódio do hospital de Lãs Mercês, disparador do pensamento de Pichon-Rivière sobre essa técnica.

Num grupo de ensino-aprendizagem a cura não é tanto a sua finalidade, mas o processo é semelhante, pois a aprendizagem ocorre quando os papéis deixam de ser estereotipados. Logo, as intervenções do professor constituem-se uma etapa importante no processo grupal, contudo, somente a instituição de um enquadre não garante o sucesso do grupo, ou seja, não é suficiente agrupar os alunos, atribuir-lhes uma tarefa e esperar que eles a resolvam por si mesmos: promover a autonomia dos alunos significa intervir diretamente no grupo.

No trabalho de Silva et al (2005) há um caso analisado que ilustra o que apontamos no parágrafo anterior: trata-se de um grupo de monitores discentes que se reunia com o professor semanalmente para discutirem suas atividades. Na reunião que foi analisada e apresentada pelos autores o professor pediu que os monitores resolvessem um exercício de Física, envolvendo os temas de circuitos elétricos, após eles relatarem sua dificuldade com este problema.

Assim que o professor apresentou o problema, os alunos disseram que não sabiam fazer, exceto uma monitora que já havia resolvido, que assumiu, por conta disto, uma posição de destaque. Em seguida, o professor deixou a sala onde estavam reunidos, 
com a intenção de que os monitores promovessem um ambiente de cooperação, como fora revelado em entrevista realizada com ele. Além disso, o professor delegou a liderança àquela monitora, para que assim, os alunos não dependessem dele.

O desfecho do grupo não foi, porém, como o esperado pelo professor. Após a sua a saída os alunos entraram num posição esquizoparanóide, por não saberem resolver o exercício, e não conseguiram superá-lo até que procuraram o pesquisadora que os acompanhava a uma certa distância. Parece-nos plausível afirmar que o grupo precisa de uma intervenção presencial do professor para ajudá-los na superação daquele momento. A delegação de líder para a monitora que sabia também não foi uma estratégia com muito sucesso, pois ela não aceitou tornar-se depositária da liderança. É a procura pela pesquisadora, então, que nos indica que os alunos estavam precisando do professor, a quem lhe atribuíram o papel de suposto saber.

Estamos afirmando, a partir do relatado, que o professor precisa estar no grupo e que promover intervenções não significa impossibilitar que os alunos atinjam a fase do projeto. Colocamos, então, a seguinte questão: qual é o lugar do professor?

O lugar do professor, de certa forma, está onde os alunos o colocam, o que significa uma relativização do mesmo e implica em uma aceitação por parte do professor. Trata-se de um jogo transferencial que ocorre entre alunos e professor: $\mathrm{o}$ grupo da mudança põe o professor no lugar do líder, porque somente poderia ocupar tal posição quem apresentasse o domínio do conteúdo. Logo, o professor nessa condição é visto como suposto saber:

- o grupo da dependência atribui ao professor esse mesmo papel, suposto saber, porém o vínculo transferencial que se estabelece é de dependência, porque somente ele poderia suprir a demanda do não saber Física;

- o grupo da resistência põe o professor no lugar de inimigo contra o qual devem lutar para a não mudança, já que o lugar institucional do grupo era ocupado por Gomes.

- o representante de duas instituições, a Escola e a Física.

Parece-nos razoável associar o sucesso de uma intervenção quando o professor aceita o lugar que o grupo o põe, ou seja, quando ele consegue promover a elaboração da tarefa implícita e reorganizar a rede de comunicação do grupo sem, no entanto, gerar uma dependência. Entendemos que o professor deve estar atento ao processo 
transferencial e explorá-lo em suas intervenções nos pequenos grupos, quando for este o caso, ou na classe como um todo, dado que também esta se constitui uma forma de grupalidade, aliás, é a situação mais comum nos ambientes de ensino-aprendizagem. Essa situação nos remete ao setting analítico.

Dessa forma, cabe outra questão: "O professor de Ciências é como um analista?". A pergunta de Villani (1999) foi colocada em um artigo no qual o autor buscou explorar a "analogia entre a estrutura de mudança de um sujeito num processo psicanalítico e num processo de aprendizagem de Ciências (...), focalizando alguns pontos interessantes na formação de um analista os quais podem dar sugestões para a formação de um professor".

A questão fundamental da analogia está na perspectiva de um confronto do sujeito (do saber) com a sua falta radical, porque, de um lado, o professor precisa ajudar o estudante a suportar a sua angústia gerada a partir da percepção de seus limites e sua impotência e, do outro, a movimentá-lo em sua busca (sem fim) de sua verdade subjetiva. "Confronto do sujeito com seus limites no campo do conhecimento e busca sem fim do saber que se engancha com sua própria verdade subjetiva parecem-nos a finalidade principal do ensino de ciência" (ibid).

Segundo o referido autor, as duas grandes tarefas do professor consistem, na perspectiva da analogia, na colaboração, ativa, para que o estudante entre no processo de aprendizagem e na sustentação do mesmo para que o sujeito atinja aquilo que puder alcançar. Será então na realização dessa tarefa que ocorrerá a relação pedagógica transferencial, termo usado pelo mesmo autor para designar, de um lado, a aceitação do estudante do saber científico e didático do professor, dispondo-se a segui-lo e do outro, a flexibilidade do professor em acreditar na potencialidade daquele, dispondo-se a orientá-lo. Nessa direção, reiteramos que o enquadre ajudará o grupo a entrar no processo, mas são as intervenções presenciais que deverão mantê-lo em processo.

Abordar o problema por essa perspectiva indica ser importante e um tanto diferente das abordagens encontradas na literatura, pois o nosso foco da análise consiste na busca de sentido para a experiência de aprendizagem ou da paralisação do processo. Em outras palavras, é possível atribuir significados para os sucessos e fracassos tanto do professor quanto dos alunos. Salientamos, contudo, que toda analogia feita deve ser 
considerada, guardando os devidos limites entre o que acontece em um campo e no outro.

Dissemos que o lugar do professor sofreu uma relativização, pois a nossa referência para tal eram os grupos primários. Entendemos, portanto, que o seu lugar se deve ainda a outros grupos, tipo secundário (Escola, Física). Então, a primeira pergunta pode ser refeita: qual o lugar do professor na instituição? Qual o lugar do professor em relação à Física? As respostas para essas questões nos parecem complexas, as quais apontamos como perspectivas futuras desse trabalho. Contudo, ressaltamos que o professor sempre terá o lugar mais essencial no processo de ensino-aprendizagem: do suposto saber ou do saber suposto.

\subsection{2-O pesquisador}

O pesquisador aparece em vários momentos como coadjuvante do professor em algumas atividades que aconteciam durante as aulas. Sua presença causava a curiosidade dos alunos, porque além de manejar a câmara sempre escrevia as suas notas de campo. Devido a isso, não raro, algum estudante brincava com a filmadora, colocando-se como um câmera-man ou perguntava-lhe sobre conteúdo e motivo das anotações.

Ao pesquisador está associado o aparato de pesquisa, microfone e câmara, que provocava diversas reações dos alunos e também do professor. A presença da filmadora provocava uma atitude narcisista dos sujeitos, sobre tudo nos momentos iniciais das gravações, pois se demonstravam preocupados com suas imagens, em como apareceriam diante do aparelho.

Pode-se pensar também no lugar do pesquisador, tal como fizemos com o professor, porém com algumas diferenciações, a começar que o primeiro não tinha a regência da classe, por conseguinte, não tinha um papel institucional. Quando ele fora apresentado pelo professor aos alunos ficou mais ou menos claro para a turma que ele atuaria algumas vezes como seu ajudante. Observamos isso nas primeiras atividades quando os grupos ficavam ressabiados de procurar o pesquisador para auxiliá-los com as dúvidas. O mais interessante é que nesses momentos, os alunos não sabiam nem mesmo como chamá-lo, ora por professor, ora por um gesto com o braço ou ainda pelo nome, quando lembravam. 
O grupo 3 foi o que manteve uma relação mais direta com o pesquisador e desde as primeiras aulas sempre o requisitavam para ajudá-los na resolução -isso talvez explique o lapso do pesquisador em obter mais filmagens deste grupo. O lugar do pesquisador para esse grupo era o do professor, como suposto saber.

As alunas do grupo 1 tinham uma relação ambígua com o pesquisador pois ora o colocavam no lugar do professor, de suposto saber, ora como um intruso, que ficava à distância espreitando-as a fim de roubar-lhes o segredo, que pôde ser observado na aula 12, em especial Carmem.

Para o grupo 2, essa o lugar do pesquisador era o mesma do professor, de inimigo. Ele foi o responsável pela introdução do aparato de pesquisa, que invadia o grupo e os pegava de todos os lados, como indicaram Gomes e Leandro. As intervenções do pesquisador nesse grupo praticamente não ocorreram, e foram alguns destes alunos que perguntaram sobre as anotações que eram feitas. Podemos inferir que grupo o via como comparsa do professor, por isso inimigo.

Contudo, do ponto de vista da pesquisa o lugar do pesquisador é outro, diferente de todos esses que inferimos que lhe foram atribuídos: ele operou no trabalho interpretativo. Aquilo que circulava no plano discursivo, gestual, os momentos de silêncio, a organização do espaço e tempo do grupo foi interpretado desde uma particular teoria cujos eventos seriam uma expressão de um sentido oculto ou latente da totalidade grupal.

Essa posição foi nomeada como o lugar de coordenação-oráculo por Fernández (2006), pois na medida em o pesquisador, "no ato interpretante, desvelava o oculto do grupo, instituía-se em um novo lugar de saber-poder", ou seja, é ele quem sabe o que acontece com grupo (p. 115). Segundo a mesma autora, embora esse tipo de "intervenção" não se trata de uma ação efetiva no grupo- como as intervenções do professor- institui-se em outra forma de liderança: "ele sabe o grupo diz quando seus integrantes falam" (ibid). 
Em outro momento de seu texto, a referida autora comenta sobre o lugar do pesquisador $^{28}$ :

"Ao ressituar a função interpretante, do lugar desvelador de verdades profundas para a pontuação interrogante, a outra cena já não é uma cena escondida; estava ali o tempo todo, lateja, insiste, e mesmo assim sua presença muitas vezes permanece denegada. Isso certamente redefine um certo lugar de 'poder' do" pesquisador $^{29}$ (p. 196)

O grupo, completa Fernández (2006), é perpassado por atravessamentos de múltiplos sentidos que sempre excederão aqueles que a inferência permite apontar, porque o pesquisador só poderá pontuar um ou outro sentido, interrogar-se sobre uma ou outra estranheza, ressaltar um paradoxo, portanto, não será mais quem descobre a verdade do que acontece no grupo.

Assim, ressaltamos que toda a produção interpretativa que consta em nosso trabalho tem o caráter de hipótese, que foi corroborada por um outro evento ocorrido no grupo. Para tanto, afirmamos que a nossa interpretação é incompleta no sentido que não se esgota em si mesmo, porém é plausível tudo o que escrevemos: "se não é verdade é bem provável!".

\section{3-Uma tarefa cumprimos...}

Uma tarefa cumprimos e nela nos conhecemos. Sei quem você é para mim trabalhando nesta tarefa. Sei que você será diferente trabalhando outra tarefa ... Você era para mim, diferente do que é hoje. Hoje conheço você, junto com o conhecimento que em CON-JUNTO conseguimos.

... Hoje conheço você mais do que ontem $e$, seguramente, menos do que amanha $\tilde{a}^{30} \ldots$

Um aspecto importante é a tarefa explícita, porque se constitui como um “organizador dos processos de pensamento, de comunicação e de ação que ocorrem na

\footnotetext{
${ }^{28}$ No seu texto a autora não usa o termos pesquisador, mas sim coordenador, pois ela se refere aos dispositivos de grupos para fins terapêuticos. Contudo, associamos a figura do pesquisador, por entendermos que ao promover as interpretações contidas neste trabalho, atua de forma semelhante, guardadas as devidas proporções.

${ }_{29}$ Idem à nota anterior.

${ }^{30}$ Trecho do poema citado no capítulo 3 , que se repetirá em outras partes deste capítulo cujo texto completo se encontra no apêndice I.
} 
situação de grupo" (FERNANDES, 2003, p.197). No caso do ensino da Física a tarefa apresenta uma característica muito peculiar que está relacionada ao fato de que a resposta a ser alcançada é fixada a priori e assim haverá um resultado certo (ou errado). Esse fator favorece que em um exercício de Física haja uma polarização para aquele aluno que domina mais o conteúdo e, por conseguinte, apresenta alguma habilidade para resolvê-lo; como conseqüência também é favorecida uma estereotipia dos papéis. A partir daí podemos pensar a função que a Física, enquanto objeto do conhecimento, cumpria para cada grupo.

Para o primeiro grupo que analisamos, inicialmente podemos dizer que na aula 8 as intervenções do professor não equilibraram a tendência à polarização da tarefa, senão reforçaram a estereotipia do papel do líder enquanto o detentor do saber. Já na outra aula, tanto a estratégia institucional (inserção das funções) quanto as intervenções que o professor realizou presencialmente tenderam a formar uma situação de equilíbrio, no sentido contrário àquela polarização. Resumidamente, saber Física é poder ser líder.

No grupo 1, havia um sentimento de incapacidade perante o conhecimento da Física, cuja manifestação foi feita por Carmem na aula 12 quando dizia que não sabia fazer, e que nem tentaria. Por outro lado, esse não saber Física é a forma como se vinculam com o professor, detentor do conhecimento. Portanto, para as alunas, o único capaz de ajudá-las, ou seja, saber Física é deixar de depender do professor.

Enquanto que no grupo 2, o conhecimento físico é marcado por atravessamentos institucionais. Em especial para Gomes, a Física representa o pai, mas como o grupo é dele, podemos inferir que essa relação é transferida para o grupal, no sentido da sua relação com o professor. Em outras palavras, o grupo resistia à atividade, que era necessário a Física para resolvê-la, por causa de Gomes que assim o fazia, cuja consequiência foi a recusa do professor também portador do conhecimento. Para o grupo do Gomes, saber Física é manter o vínculo com o pai. 
Por fim, resgatamos uma fala da Rebeca com o professor durante aula 12 que pode nos dar indícios da relação dos estudantes, de um modo geral, com conhecimento da Física.

"Quer dizer, que é assim, a gente vê uma coisa fácil, e aí a gente fala: 'não é isso, não pode ser!' Porque Física é difícil! Então a gente vê uma coisa muito fácil ou a gente tá entendendo, fala que é difícil, não pode ser, Física é difícil. Aí a gente vai procurar outra coisa, mais complicada ainda!” (Rebeca, aula 12-episódio 12.15).

Por outro lado, "a tarefa de aprender e o tema correspondente canalizam a atenção direta do grupo e de seu coordenador; mas (...) o que fundamentalmente nos interessa são os seres humanos nela implicados, de tal maneira que (...), uma boa tarefa é simultânea à integração e à aprendizagem grupal" (BLEGER, 2001; p81). É preciso, então, que a tarefa desperte no aluno um montante de ansiedade, mantendo uma distância com o objeto de conhecimento, de tal forma que a ansiedade seja como um sinal de alarme. Isso significa que deve haver uma "distância ótima, que corresponde a uma ansiedade ótima, acima ou abaixo da qual a aprendizagem fica prejudica” (ibid, p83).

A tarefa explícita deve ser foco da atenção dos professores que se aventurarem com trabalhos com grupo, pois ela tem uma relação direta com o objeto de conhecimento. Então, que tipo de atividades, exercícios ou problemas poderão ser usados como tarefa para um grupo de ensino-aprendizagem? Trata-se de uma questão que nos põe na perspectiva futura que pretendemos com esta dissertação de mestrado.

\section{4-O final}

$$
\begin{array}{r}
\text { A criação surge como um manancial } \\
\text { nesta modalidade, } \\
\text { onde produtores produzem } \\
\text { e gozam de sua produção. } \\
\text { O produto nunca é final, } \\
\text { ainda que uma etapa seja finalizada, } \\
\text { mas está em permanente } \\
\text { PRINCÍPIO E FINAL... }
\end{array}
$$

Este trabalho tem duas características fundamentais: a investigação sobre os grupos durante as aulas de Física e o uso de um referencial embasado na psicanálise. Esta tem se apresentado como uma importante contribuição para o campo educacional 
na medida em que se torna possível a percepção de situações nos processos de ensinoaprendizagem, as quais poderão ter um desfecho diferenciado.

A esse propósito, encontramos um trabalho em que os autores investigaram alguns impasses no processo de ensino-aprendizagem de Física em três situações distintas- um curso de Mecânica Analítica para uma pós-graduação, um curso de formação continuada para professores de Física e um grupo numa aula de Física do Ensino Médio. Foi detectado que em todos eles havia o desconhecimento por parte dos condutores do processo dos efeitos do impasse (VILLANI et al, 2004). A suposição dos autores é que a psicanálise, ao propor questões de ordem subjetivas, pode ajudar os professores a focalizar o núcleo desses impasses e possibilitar mudanças no processo.

A nossa suposição básica está nessa mesma direção, em que o conhecimento sobre o processo grupal- os conflitos, a latência, as projeções e múltiplas transferências, os medos básicos, os papéis e comunicação entre os membros- torna-se importante para o manejo, com relativo sucesso, dos pequenos grupos, quando for o caso, ou da própria dinâmica da sala. Sucesso não significa necessariamente que todos os grupos obtenham os resultados esperados, senão o reconhecimento das situações tipo impasse, por parte do professor, e a busca por novas (outras) formas de conduzir o seu trabalho com os alunos.

Se assumirmos uma prática que favoreça os trabalhos com grupo, surgem outras questões que podemos chamá-las de ordem prática: como realizamos tais atividades em uma classe com 40 alunos? Como avaliamos os grupos: com provas individuais ou coletivas? Se a prova aplicada for coletiva, quais seus critérios de correção? Deve ser considerada a mesma nota para todos os membros do grupo ou será calculada a partir de uma combinação com as observações dos alunos nos grupos? Que tipo de tarefa deve ser usada para favorecer o processo grupal? Contudo a pergunta principal é: qual é o lugar dos grupos nas instituições de ensino-aprendizagem?

Se o uso dos grupos durante as aulas é difícil, uma proposta para sua efetivação está nas aulas reservadas para reforço ou plantão de dúvidas ou então, no processo de recuperação continuada, que devem ser oferecida pelas instituições aos alunos que não conseguiram alcançar a nota mínima tanto no fim de cada bimestre ou trimestre quanto no fim do ano. Na perspectiva dos grupos operativos, a recuperação (de conteúdo ou de nota) pode ser re-significada e ampliada para uma recuperação do sujeito; uma nota 
baixa com muita recorrência pode ser um sintoma de que algo no aluno não está bem. Segundo Bleger (2001) no "ensino grupal deve-se procurar caminhar para o desconhecido, para indagação daquilo que ainda não está suficientemente elucidado" (p.67). Aquilo que não é elucidado poder ser a causa de algo que não está bem. Um outro espaço oportuno são os laboratórios de Física, cuja estrutura prevê a organização dos grupos para as atividades (BAROLLI, 1998; BARROS et al, 2007). Contudo, é preciso deixar claro que, com essas proposições, não é nossa intenção transformar as aulas em formas de terapias em grupo, senão aproveitar os potenciais dessas técnicas terapêuticas para as situações de sala de aula. Sobre o ensino grupal, Bleger (2001) ainda afirma que:

"O desconhecido é perigoso (persecutório) e pode desorganizar as defesas do grupo, que se vê, então invadido pelo tema. [Em uma outra situação] deve-se fazer com que o cotidiano e comum, o já conhecido, torne-se 'estranho', quer dizer, mostrá-lo sob aspectos diferentes dos estereotipados" (p. 84).

Em resumo, podemos dizer que conhecer os resultados do processo de aprendizagem nos grupos dos alunos constitui uma informação importante para o professor poder regular as atividades de sala de aula e modificar suas intervenções. Quando o professor optar por uma dinâmica que envolve grupos, o conhecimento das situações que ali acontecem e do processo de desenvolvimento dos grupos é muito importante para que as intervenções alcancem a meta visada. Pelo que pudemos notar em nossos casos, o ponto fundamental que deveria constituir objeto especial de análise do professor é a circulação ou não dos papéis, a comunicação e a elaboração da tarefa, tanto dos alunos quanto do professor. Assim, por um lado, o professor deveria tentar explorar a relação de transferência que os alunos vivenciam em relação a ele para favorecer a circulação dos papéis nos grupos. Por outro lado, a relação de dependência dos alunos em relação ao professor, por ser demasiadamente intensa, não permite que surjam lideranças entre eles. Neste caso o professor deveria explorar os vínculos entre os alunos, reforçando-os para diminuir a dependência inicial.

Todas essas considerações nos remetem a um questionamento da opinião bastante compartilhada na área de Ensino de Ciências de que trabalhar com pequenos grupos é uma estratégia docente vitoriosa. O resultado de nossa e de pesquisas anteriores (BARROS, 2002) sugerem que a exploração de grupos de aprendizagem em sala de aula de ciências deve ser realizada quando o professor consegue ter um controle 
(relativo), cognitivo e afetivo, sobre os mesmos, ou seja, quando ele consegue entender o que ocorre nós vários grupos e, sobretudo, explorar a transferência pedagógica em favor do desenvolvimento dos mesmos. Sem essa noção mínima, os resultados podem ser mais insatisfatórios do que a modalidade de instrução tradicional.

Em virtude do exposto, recorremos à letra da música $O$ anjo mais velho, do grupo $O$ teatro mágico, que providencialmente diz:

Enquanto houver você do outro lado Aqui do outro eu consigo me orientar A cena repete a cena se inverte enchendo a minha alma d'aquilo que outrora eu deixei de acreditar tua palavra, tua história tua verdade fazendo escola e tua ausência fazendo silêncio em todo lugar metade de mim agora é assim de um lado a poesia o verbo a saudade do outro a luta, a força e a coragem pra chegar no fim

e o fim é belo incerto... depende de como você vê o novo, o credo, a fé que você deposita em você e só

Só enquanto eu respirar ...Vou me lembrar de você! 
CAPÍTULO 7 


\section{7-REFERENCIAS BIBLIOGRÁFICAS}

ABDUCH, C., Grupos Operativos com Adolescentes. Cadernos da juventude 2004. Disponível em http://www.adolec.br/bvs/adolec/P/cadernos/capitulo/cap28/cap28.htm

ANZIEU, D.; MARTIN, J. Y. La dinámica de los grupos pequeños. Buenos Aires: Kapelusz, 1971.

ARRUDA, S. M, Entre a inércia e a busca: reflexões sobre a formação em serviço de professores de física do ensino médio. 230f. Tese (Doutorado em Educação)Faculdade de Educação, Universidade de São Paulo, São Paulo, 2001.

BARROS, J. A., SILVA, G. S. F., TAGLiATI, J. R., REMOLD, J. Engajamento Interativo no curso de Física da UFJF. Revista Brasileira de Ensino de Física. SBF, v 26, n 1, p 63-69, 2004.

BARROS, M A. Análise de experiências didáticas com grupos de aprendizagem num curso de Física. 107f+anexos. Tese (Doutorado em Educação)-Faculdade de Educação, Universidade de São Paulo, São Paulo, 2002.

BARROS, M A \& VILLANI, A. A dinâmica de grupos de aprendizagem de física no ensino médio: um enfoque psicanalítico. Investigações em Ensino de Ciências. Porto Alegre, v 9, n 2, 2004.

BARROS, M. A, LABURÚ, C. E., ROCHA, Z. F. D. C. Análise do vínculo entre grupo e professor numa aula de ciências do ensino fundamental. Ciência e Educação. Bauru, v 13, n 2, p 235-251, 2007.

BAROLLI, E. Reflexões sobre o trabalho dos estudantes no laboratório didático. Tese (Doutorado em Educação)- Faculdade de Educação, Universidade de São Paulo, São Paulo, 1998.

BAROLLI, E., VILLANI, A., Laboratório Didático e Subjetividade. Investigações em Ens. de Ciências. Porto Alegre, v 3, n 3, 1998.

BAROLLI, E. VALADARES, J. M., VILLANI, A. Explicitando uma metodologia de pesquisa: a experiência de uma professora de Física revisitada. Ciência e Educação. Bauru, v 13, n 2, p 253-271, 2007.

BLEGER, J.,Grupos operativos no ensino, In: Temas de Psicologia, entrevistas e grupos. $2^{\mathrm{a}}$ ed.(2 $2^{\mathrm{a}}$ tiragem) São Paulo: Martins Fontes, 2001.

BRASIL, Parâmetros Curriculares Nacional: ensino médio. Secretaria de Educação e Tecnológica. Brasília: MEC, SENTEC, 2002.

BROWN, J S; COLLINS, A \& DUGUID, P. Situated cognition and the culture of learning. Educational Researcher, v 1, n1, p 32-42, 1989.

CABRAL, T. C. B. Contribuições da psicanálise à educação matemática: a lógica da intervenção nos processos de aprendizagem. 233f. Tese (Doutorado em Educação)Faculdade de Educação, Universidade de São Paulo, São Paulo, 1998.

CARVALHO, A. M. P. Uma metodologia de pesquisa para estudar os processos de ensino e aprendizagem em salas de aula. In: SANTOS, F. M. T.; GRECA, I (orgs). A pesquisa em ensino de ciências no Brasil e suas metodologias. Ijuí-RS: Unijuí, 2006. p. 13-48. 
CIAMPONE, M.H.T, Grupo Operativo: construindo as bases para o ensino e a prática da Enfermagem Tese (Livre Docência)- Escola de Enfermagem, Universidade de São Paulo, São Paulo, 1998

COLL, C. Os conteúdos na reforma. Porto Alegre: Arte Médicas, 2000.

DUSCHL, R. Más allá del conocimiento: los desafios epistemológicos sociales de la enseñanza mediante el cambio conceptual. Enseñanza de las Ciências, v. 13, n 1, 1995.

FERNANDES, L. M. Um olhar winicottiano sobre a relação dos estudantes com o próprio processo de aprendizagem. 112f. Dissertação (Mestrado em Ensino de Ciências- modalidade Física)- Instituto de Física, Faculdade de Educação, Universidade de São Paulo, São Paulo, 2007.

FERNANDES, M. I A. De como emerge a questão do narcisismo e da alteridade no grupo operativo. Tese (Doutorado em Psicologia)-Instituto de Psicologia, Universidade de São Paulo, São Paulo, 1989.

FERNADES, W. J et al (Orgs). Grupos e configurações vinculares. Porto Alegre: Artes Médicas, 2003.

FERNÁNDEZ, A. M. O campo grupal: notas para uma genealogia. São Paulo: Martins Fontes, 2006.

FERREIRA, M. P.P. Análise e Interpretação de um curso de segundo grau sobre as Leis de Newton. Dissertação (Mestrado em Ensino de Ciências-modalidade Física)Instituto de Física/ Faculdade de Educação, Universidade de São Paulo, São Paulo 1997.

FILHO, J. C. S. \& GAMBOA, S. S. (Orgs). Pesquisa educacional: quantidadequalidade. Questões de nossa época. $2^{a}$ edição. São Paulo: Cortez, 1997.

FRANZONI, M. Os pontos de ressonância entre os convites docentes e a construção de saberes na formação inicial de professores. 153f. Tese (Doutorado em Educação)Faculdade de Educação, Universidade de São Paulo, São Paulo, 2004.

GIDDENS, A. As consequiências da modernidade. São Paulo: Ed. Unesp, 1991.

GIORDAN, M. Algumas questões técnicas e metodológicas sobre o registro da ação na sala de aula: captação e armazenamento digitais. In: SANTOS, F. M. T.; GRECA, I (orgs). A pesquisa em ensino de ciências no Brasil e suas metodologias. Ijuí-RS: Unijuí, 2006. p. 213-238.

HAKE, R. Interactive- engagement vs traditional methods: A six- thousand- student survey of mechanics test data for introductory physics courses. Am. J. Phy, v. 66, n 1 p 64-74, 1998.

HELLER, P. et al., Teaching problem solving through cooperative grouping. Am. J. Phy. v 60, n 7, p 627 -644, 1992.

HELLER, P., et al, Cooperative Group Problem Solving in Physics, University of Minnesota, 1999. Disponível em http://www.ph12sics.umn.edu/groups/ph12sed

JULIO J. \& VAZ, A., O professor de Física como "co-pensor" de grupos operativos de alunos do Ensino Médio. In: ENCONTRO DE PESQUISA EM ENSINO DE CIÊNCIAS, 5, 2005, Bauru. Anais... Bauru: ABRAPEC, 2005. 1 CD-ROM.

KIRSCHNER, P. A. Epistemology, practical work and academic skills in science education. Science \& Education. v 1, p. 273-299, 1992. 
KUPFER, M. C. Freud e a educação: o mestre do impossível. São Paulo: Scipione, 1989.

LABURÚ, C E; SILVA, D \& CARVALHO, A M P. Analisando uma situação de aula de termologia com o auxílio do vídeo. Revista Brasileira de Ensino de Física. SBF, v 22, n 1, 2000.

LAPLANCHE, I. \& PONTALIS, J-B. Vocabulário de Psicanálise. São Paulo: Martins Fontes, 1988.

LOPES, E. M. T. (org) A psicanálise escuta a educação. Belo Horizonte: Autêntica, 1998.

LÜDKE, M., ANDRÉ, M. E. D. A. Pesquisa em educação: abordagens qualitativas. Temas básicos da educação e ensino. São Paulo-SP: EPU, 1986

MARTINS, S. T. F., Educação científica e atividade grupal na perspectiva sóciohistórica. Ciência \& Educação. Bauru, v 8, n 2, p. 227-235, 2002.

MIZUKAMI, M. G. N. Ensino: as abordagens do processo. Temas básicos da educação e ensino. São Paulo: EPU, 1986.

MOREIRA, M. A., Pesquisa em Ensino: O Vê Epistemológico de Gowin. Temas Básicos de Educação e Ensino. São Paulo: EPU, 1990.

PICHON-RIVIÈRE, E. O Processo Grupal. $7^{\circ}$ edição. São Paulo: Martins Fontes, 2005.

PICHON-RIVIÈRE, E. Teoria do Vínculo. 5a edição. São Paulo: Martins Fontes, 1994.

ROCHA, Z. F. D. C, Análise da Dinâmica de um Grupo de Aprendizagem em Ciências no Ensino Fundamental, Dissertação (Mestrado em Ensino de Ciências e Educação Matemática)-Departamento de Física, Universidade Estadual de Londrina, Londrina, 2005.

SANCHEZ, R. U., Grupos Operativos de aprendizagem: uma perspectiva de mudança para a relação ensino-aprendizagem. Dissertação (Mestrado em Ensino de Ciências-modalidade Física)-Instituto de Física/ Faculdade de Educação, Universidade de São Paulo, São Paulo, 2002.

SANTOS, A. C. S. O processo grupal na sala de aula- emergência do mundo interno nos relatórios vivenciais. Dissertação (Mestrado em Psicologia)-Instituto de Psicologia, Universidade de São Paulo, São Paulo, 2004.

SANTOS, F. M. T.; GRECA (Orgs). A pesquisa em ensino de ciências no Brasil e suas metodologias. Ijuí-RS: Unijuí, 2006. p. 213-238.

SILVA, C. A. Teorias de grupo em pauta: contribuições ao campo educacional. $195 f$. Dissertação (Mestrado em Educação)-Faculdade de Educação, Universidade de São Paulo. São Paulo, 2000.

SILVA, G. S. F., GUIMARÃES, L. F., VILLANI, A. Grupos de aprendizagem: o papel das intervenções do professor. In: ENCONTRO DE PESQUISA EM ENSINO DE CIÊNCIAS, 5, 2005, Bauru. Anais... Bauru: ABRAPEC, 2005. 1 CD-ROM.

SILVA, S. F. G, VILLANI, A. A construção de intersubjetividades nas aulas de Física: como e por que um grupo funciona? In: ENCONTRO DE PESQUISADORES EM ENSINO DE FÍSICA, 10, 2006, Londrina. Anais... Londrina: SBF, 2006. 1 CD-ROM 
SILVA, S. F. G, VILLANI, A. Grupos de aprendizagem nas aulas de Física: as interações entre professor aluno. Ciência \& Educação. Bauru, (a aparecer), 2008.

SOUTO M. Hacia una didática de lo grupal. Buenos Aires, Ed. Miño y Dávila, 1993.

SOUTO, M. (org). Grupos y dispositivos de formación. 1ª edição. Buenos Aires: Ediciones Novedades Educativas, 1999. 
VALADARES, J.M., As formas e a construção da subjetividade em um grupo de professores: análise de uma prática e seus discursos. Dissertação (Mestrado em Ensino de Ciências-modalidade Física)-Instituto de Física/Faculdade de Educação,Universidade de São Paulo. São Paulo, 2002.

VALADARES, J. M. \& VILLANI, A, Crise, mudança e intermediário: o papel do professor de ciências na constituição das relações intersubjetivas em um grupo de professores. Ensaio-Pesquisa em Ensino de Ciências. Belo Horizonte, v 6, n 1, 2004.

VILLANI, A. \& CABRAL, T. C. B., Mudança Conceitual, Subjetividade e Psicanálise, Investigações em Ensino de Ciências. Porto Alegre, v 2, n 1, 1997.

VILLANI, A. O professor de ciências é como um analista? Ensaio-Pesquisa em Ensino de Ciências. Belo Horizonte, v 1, n 1, p 1-27, 1999.

VILLANI, A., BARROS, M. A., ARRUDA, S. M. Impasses na sala de aula de ciências: a psicanálise pode auxiliar? Revista Brasileira de Pesquisa em Ensino de Ciências. Bauru, v 4, p 1-12, 2004.

VILLANI, A et al. Contribuições da Psicanálise para uma Metodologia de Pesquisa em Educação em Ciências In: SANTOS, F. M T \& GRECA I M (Orgs). A Pesquisa em Ensino de Ciências no Brasil e suas Metodologias, Ijuí: Ed. Unijui, 2006. p 323-390.

ZIMERMAN, D. Fundamentos Básicos das Grupoterapias. Porto Alegre: Artes Médicas, 1993. 


\section{APÊNDICE I}

Estava pensando nos grupos e de repente me dei conta:

como é difícil manter-se em situação.

Muitos querem tirar-nos dela. São aqueles que se mantém em confusão.

Porque seguro estou ... de por ela termos de passar (a confusão)

porque é o primeiro momento que todo grupo atravessa a caminho de sua organização.

Conta-nos Sartre, e outros também, que os grupos primeiro se formam do coletivo (série) tentando sair. Reúnem-se aqueles que conseguiram com o OUTRO falar ...

e, nesse momento, não mais eu, com você, quero falar!

Falando já estamos, companheiro, mas falta algo mais ...

Com quem você veio?

Com um amigo, e talvez mais! ...

Eu também tenho um, e outros mais. Pois adiante, quando nos reunimos?

E assim há de começar ...

uma, duas e mais reuniões também. É um momento de FUSÃO.

O denominador é a CON-FUSÃO.

Mas, seguramente ...

deste momento há que sair, porque o homem em SITUAÇÃO não pode permanecer na confusão, embora, por ela, sempre tenha que passar:

esse é o caminho do viver.

Não vem quem não passa pela confusão.

Não vem quem fica na confusão.

Porque é um momento do todo em sua totalidade ...
Mas não há de ser a totalidade do todo.

Na primeira reunião, Já se falou de TAREFA.

Só se a anunciou ...

mas o grupo se centrou.

Porque não há grupo sem tarefa.

Essa é uma realidade:

explícita ou latente, sempre ela existe.

Ao passar pelo momento da fusão, dois caminhos hão de sobrar:

um, cego e sem rumo, sustém a confusão ... Não consegue outra coisa do que manter o terror e a violência. É o caminho do JURAMENTO Quem sabe ... um dos mais comuns da atualidade.

Um líder forte e autocrático as normas há de impor e o resto terá de aceitar dele, sua autoridade.

É um gênio! dizem alguns e assim o grupo toca e dança uma só canção ... Empobrece-se a criação e o que sobra é: só estar ...

Alguém há de desertar por já não mais agüentar esta situação, que sitia o homem, e o não o deixa em SITUAÇÃo estar...

TRAIDOR !!!

Escutar-se-á, e a violência há de imperar, - Há que castigar o traidor!!! e este, muito longe há de estar para não arrebentar ... Às vezes passa o tempo e ... o perdão ...

Já não chateia mais ... Triste caminho estes grupos percorrem, 
sem se separar da serialidade a ela voltaram através de sua organização.

Só um dirige

e a hierarquia há de imperar ...

Tornaram-se estranhos

uns aos outros.

Por já não mais "Com você falar"

Só podem, uns e outros

CONSPIRAR ...

Selam seu diálogo

com a conjura ...

e tristes se entregam

à sua solidão ...

Aprendem a atuar

com presteza e decisão,

mas não podem decidir ...

Só a hierarquia

pode pensar e decidir,

e a ela querem chegar.

Mas, para isso,

ao outro devem superar.

Um se converte no rival do outro.

Já não mais: COM VOCÊ FALAR ...

Só, com você: DEVO LUTAR!!!

Pode esta situação

por muito tempo perdurar.

Há grupos que do juramento

fazem sua devoção.

Mas tudo pode mudar encontrando o caminho que saída permanente nos dá.

Passo agora a contar

sobre o outro caminho

o da LIBERDADE.

Os homens em situação, terão de passar pela confusão que é o caminho da fusão Dele sairão

com normas a comunicar EM PERMANENTE E DIALÉTICA COMUNICAÇÃO.

Todos entram na normatização e as normas saem da totalidade. Uma autoridade há que existir para que essas normas faça cumprir, e esta autoridade será:

Um grupo especial.

Sua LIDERANÇA, MÚTIPLA será:

vários a exercerão.

Cumprir-se-á a FUNÇÃO

que por isso foi chamada: LIDERANÇA

FUNCIONAL.

A organização não está organizada, mas em permanente organização.

Os sujeitos não são hoje

o que foram ontem

e o que serão amanhã.

De sua mudança são responsáveis

e juntamente com os demais, a

produzem.

Porque não há coisa mais linda

do que sermos produtores de NOSSA

PRODUÇÃO.

Os outros nos mostram nossas

mudanças,

nós lhes mostramos as suas.

Porque este é o momento da

AVALIAÇÃO.

É de nOVo RECOMEÇAR.

Porque tornar a começar (ou

recomeçar)

não é o mesmo que o começo.

Já na avaliação, diferentes nos vimos

e apesar de podermos ser os

mesmos,

ESTAMOS DIFERENTES. SOMOS

DIFERENTES.

Uma tarefa cumprimos

e nela nos conhecemos.

Sei quem você é para mim

trabalhando nesta tarefa.

Sei que você será diferente

trabalhando outra tarefa ...

Você era para mim, diferente do que

é hoje.

Hoje conheço você, junto com o

conhecimento

que em CON-JUNTO conseguimos.

... Hoje conheço você mais do que

ontem

e, seguramente, menos do que

amanhã ...

Já estou propondo

FALAR COM VOCÊ. 
Traz um amigo, e outro mais.

Há que recomeçar!!!

De novo a fusão,

a con-fusão

e esses dois caminhos ...

De novo a organização,

Olho no juramento!

Seguramente iremos roçá-lo

porque não há coisa mais tentadora

do que estar juramentados.

Os líderes sempre prontos estão ... e aqui me ponho e me EXPONHO para que vocês também se exponham ... e já pondo e expondo estamos !!!

Se só um é líder, olho no juramento!!! Se são muitos mais,

(Carlos Alberto Guerín) liderança múltipla e funcional, em um momento da tarefa, só um funciona, em sua liderança funcional. Os outros CO-OPERAM e prontos já estão para em outro momento liderar.

Que coisa mais linda a da liderança múltipla e funcional. A criação surge como um manancial nesta modalidade, onde produtores produzem e gozam de sua produção. O produto nunca é final, ainda que uma etapa seja finalizada, mas está em permanente PRINCÍPIO E FINAL 


\section{APÊNDICE II}

\section{II.1-Aspecto epistêmico, o campo teórico}

Se antes nos preocupamos com o "ser" do grupo, no sentido etimológico, agora apontaremos para o campo teórico, isto é, como se constroem os conhecimentos sobre o campo grupal. Iniciamos com a seguinte citação:

“As pesquisas (...) apresentam muitas vezes o grupo pensado
como tendo um lugar no psiquismo do individual e, outras vezes
apresentam o grupo pensado como realidade sociológica. Mais
adiante o vemos sendo colocado como o objeto' a ser
investigado, sem que se tenha, contudo, o mínimo de acordo
sobre o que ele representa. E, outras vezes, colocado como
espaço intermediário entre o sujeito e a sociedade, como um
campo de produções ou como campo de revelações. E, de outro
lado, um dispositivo de intervenções" (FERNANDES, 1989, p19-
20, grifo nosso)

O que temos acima é uma visão geral da produção teórica sobre os grupos e vemos que o campo da teoria é um tanto confuso no sentido de que há muitas produções teóricas que são de natureza distinta, isto é, dizem respeito a diferentes áreas da ciência como, por exemplo, a Psicologia e a Sociologia. O nosso esforço nesta seção será desmembrá-las indicando como o grupo é concebido em cada uma delas. Não pretendemos fazer uma discussão muito aprofundada de cada uma das áreas que investigam os grupos, vamos apenas tangenciá-las descrevendo os seus principais aspectos. Optamos por fazer este caminho de elucidação sobre o campo grupal a fim de justificar a nossa escolha pelo modelo dos grupos operativos, pois acreditamos que assim o localizamos com mais precisão dentro do campo teórico.

Começamos pela Sociologia que vai tratar os grupos como sistemas de interação social, como unidades fundamentais da estrutura social. A Sociologia vai ainda criar modelos para tentar explicar as posições e funções desses grupos dentro da organização social incluindo-se aí desde as grandes massas até os pequenos coletivos nos quais o número de pessoas é restrito. Trata-se de uma "tradição externalista", pois ela vai olhar para os grupos como parte da organização social pensando sua função dentro dela, ou seja, a Sociologia vai estudar a sociedade como grupos, e não os grupos em suas características específicas. 
A Psicologia, que pode ser considerada como "tradição internalista", vai pensar os grupos como sociedades e se preocupar com o comportamento individual dos sujeitos nestas sociedades tornando os grupos um ambiente importante para observação do comportamento individual. Ao pensá-los desde seu interior, a Psicologia centrar-se-á nas funções e papéis que cada sujeito exerce neste ambiente coletivo. Por esse motivo, há uma opção preferencial para os pequenos grupos sem, contudo, descartar estudos com as grandes massas.

Cada uma dessas tradições de pesquisa contribui com uma definição de grupo. Sendo assim:

"Na tradição sociológica o grupo é definido como um número de pessoas, grande ou pequeno, com relações mútuas, o qual é possível ser visto como um conjunto dentro da estrutura social. Na psicológica, o grupo é uma entidade dinâmica constituída por indivíduos com vínculos entre si, com percepção coletiva de unidade e de pertença ao grupo" (SOUTO, 1999, p. 37; grifo e tradução nossos).

Em ambas as definiçõoes são evidentes as relações entre os membros do grupo, mas com perspectivas diferentes que percebemos no uso dos termos "relações mútuas" e "vínculos" O que nos parece é que o segundo focaliza o sujeito que se relaciona e se vincula e não somente suas relações.

As duas tradições marcam o inicio de uma sistematização de teorias sobre o campo grupal. Ao olharmos para o nosso pequeno levantamento histórico veremos que o grupo não existia como representação e como objeto de conhecimento. Esse termo passa a ser usado na época renascentista e passa designar uma reunião de pessoas a partir do século XVIII. Desde então e até o final do século XIX o grupo é tratado como objeto de investigação de forma quase especulativa sendo somente a partir do início do século passado que ganham mais notoriedade os estudos sobre esse assunto.

Porém, é com surgimento da Psicologia Social (PS), que constitui o campo teórico de interface entre a Sociologia e a Psicologia, que o estudo dos grupos ganha força, marcando um momento de maior produção de teorias, técnicas e investigação. Alguns investigadores ${ }^{31}$ daquela época, advindos das duas tradições de pesquisa, defendiam que os dispositivos grupais enquanto espaço de interações e representações

\footnotetext{
${ }^{31}$ Pensadores como Durkheim, da sociologia, Freud da psicanálise e também G. Mead são alguns dos investigadores que fazem menção sobre o estudo dos grupos em um campo específico de interface entre a sociologia e a psicologia (Souto, 1999)
} 
sociais são melhores estudados nessa "região" de interface, pois a PS "ao ocupar-se da natureza social do indivíduo e dos espaços interpessoais, permite o estudo científico dos grupos como lugar privilegiado para a interação" (SOUTO, 1999, p 37, tradução nossa).

Na PS um nome importante é o de Kurt Lewin quem afirmava que a "Psicologia aprendeu a dar-se conta da extraordinária importância dos fatores sociais em praticamente toda espécie de comportamento (...), pois desde o primeiro dia de sua vida, a criança faz parte de um grupo e morrerá se o grupo não cuidar dela" (LEWIN 1970, p.87-88). Psicólogo da Escola de Berlim, Lewin, em meados da década de 30 do século passado, introduziu entre os psicólogos a noção de dinâmica de grupo, a qual se dá nos dispositivos grupais devido a um jogo de forças antagônicas em que por um lado constituem as partes de um todo, ou seja, "o grupo é um todo cujas propriedades são diferentes da soma das partes e por outro, as forças que tendem a desintegrar o conjunto" (FERNÁNDEZ, 2006 p.66). Logo, os problemas que serão mais amplamente abordados por Lewin e seus colaboradores dizem respeito à unidade do grupo e à sua permanência como uma totalidade dinâmica.

A noção de grupo para Lewin vai se estabelecendo a partir dos seus resultados encontrados, como em uma das suas experiências com crianças ${ }^{32}$ na qual se montam grupos com duas atmosferas sociais diferentes, uma autoritária e outra democrática, cujo objetivo era montar uma estrutura em que possibilitaria compreender a dinâmica subjacente do grupo. Mais tarde, realizou-se outra experiência com outros sujeitos numa terceira atmosfera, a de laissez-faire. Sua conclusão consiste na idéia de que os climas sociais determinam em certa medida o comportamento e atitudes dos indivíduos nos grupos, e as atmosferas são determinadas pelo tipo de liderança que se estabelece no ambiente grupal. A partir daí Lewin (1970) vai afirmar que :

"O clima social em que vive uma criança é, para ela, tão importante quanto o ar que respira. $\mathrm{O}$ grupo a que ela pertence é o solo em que pisa. Sua relação com esse grupo e sua posição nele constituem os fatores mais importantes do seu sentimento de

\footnotetext{
${ }^{32}$ Em 1938, foram montados dois grupos de crianças de dez e onze anos de idade provenientes de duas diferentes classes de uma mesma escola para formarem um clube de fabricação de máscaras. Houve onze reuniões, sendo que o grupo democrático se reunia dois dias antes do autocrático. Como características gerais, o democrático escolhia livremente suas atividades, enquanto que o outro sempre recebia ordens. Buscava-se manter tudo com o máximo de similaridade entre os grupos, com exceção da atmosfera. $\mathrm{O}$ líder nos dois casos era um estudante adulto que tentava criar as atmosferas utilizando algumas técnicas, como por exemplo, os planos de ação. No caso do grupo democrático são resultados das discussões do grupo e são encorajados pelo líder. No outro grupo, a tomada de decisões se dá sempre pelo líder (LEWIN, 1970).
} 
segurança ou insegurança. Não admira que o grupo de que a pessoa faz parte, e a cultura em que vive, determinem em grande parte seu comportamento e caráter. Esses fatores sociais determinam o espaço de movimento livre de que dispõe, e até que ponto ela pode prever, com alguma clareza, o seu próprio futuro" (p. 97-98). Logo, "O grupo a que pertence o indivíduo constitui a base de suas percepções, ações e sentimentos e a liderança é o determinante da atmosfera do grupo" (p. 7).

Kurt Lewin se esforçava para que a Psicologia (Social) fosse reconhecida como ciência, por isto, foi pioneiro ao introduzir uma metodologia experimental com a criação de grupos artificiais ou grupos-controle, de pequena dimensão com tarefas semelhante às dos grupos reais onde o pesquisador deveria estar imerso no seu ambiente de pesquisa. Isso consistia uma novidade metodológica, conhecida por investigação ativa ou action-research (FERNÁNDEZ, 2006).

Seus estudos e suas práticas metodológicas possibilitaram que um conjunto de investigadores se preocupasse com os fenômenos que se produzem especificamente nos pequenos grupos: a coesão dos membros, o conflito, a moral própria, as regras, o clima que se estabelece no grupo, a liderança, os papéis, e a comunicação. As técnicas associadas aos grupos acompanham este refinamento, como conseqüência, surge dentro desse panorama um novo tipo de profissional que é o coordenador (animador, instrutor, monitor ou moderador) do grupo. E o seu papel passa a ser pensado de forma mais específica para dar conta de uma nova demanda: a terapia de grupo que é utilizada mais amplamente a partir das décadas de 50 e 60 do século passado.

Ao mesmo tempo em que surgia a terapia de grupo, essa forma de intervenção também ganhava importância sendo cada vez mais sofisticada com a entrada de outros pontos de vista, como a Psicanálise ${ }^{33}$, no trabalho e na teorização sobre o grupal. As primeiras contribuições nesse sentido foram de orientação anglo-saxã introduzindo conceitos e técnicas psicanalíticas para a compreensão dos grupos humanos as quais foram usadas em seguida para a formação de coordenadores de grupo e nas intervenções institucionais (ibidem).

A Psicanálise, que tem como método básico a interpretação, ao se voltar para grupos passa a se preocupar com as relações interpessoais tendo em vista os processos

\footnotetext{
${ }^{33}$ Psicanálise foi termo criado por Freud para designar um método para investigação de processos mentais de outro modo quase inacessíveis que baseado nessa investigação é usado no tratamento de desordens neuróticas. Por meio das associações livres do sujeito criam interpretações que conduzirá o paciente á tomada de consciência do conteúdo psíquico nele recalcado (LAPLANCHE \& PONTALIS, 1988).
} 
inconscientes ocorridos nas transferências e contratransferências vividos pelos os atores do processo grupal. Então, quando se introduziu essa abordagem dos grupos logo surgiu uma questão importante entre os autores dessa corrente: interpretar quem? Pois era possível ter o foco ou no sujeito que compõem grupo ou no grupo como uma totalidade. Essa mirada dependerá de como os autores entendiam o setting grupo-analítico. Entre os estes damos destaque para Bion e Folkes da escola inglesa; Anzieu e Kaës (este mais contemporâneo) na França e Pichon-Rivière na Argentina.

Concluímos que a noção do que é um grupo e como abordá-lo está relacionado com o "corte epistemológico" feito dentro do campo teórico, isto é, a noção de grupo para Sociologia difere em alguns aspectos da Psicologia e da Psicanálise. A consequiência está nas técnicas de grupo que estão apoiadas em uma teoria para que tenham uma eficácia satisfatória. Logo, não é possível dizer que é um grupo sem conjugar os dois aspectos, o etimológico e o epistemológico. O primeiro diz respeito ao "ser" do grupo enquanto o segundo trata de como se constroem os conhecimentos sobre o grupal.

\section{II.2-Ajustes de terminologias sobre a grupalidade}

A necessidade de se pensar o grupo surge da percepção de que "as ações de um grupo se distinguem das ações individuais, porque se relacionam com a pluralidade ou com um aglomerado de indivíduos" (ANZIEU, 1971, p.22, tradução nossa). Damos-nos conta, então, de que há várias possibilidades de ocorrer essa pluralidade. Em nossos estudos estamos tratando todas como grupo. Contudo, essa reunião de indivíduos pode adotar diferentes formas, tornando necessárias denominações específicas para identificá-los devidamente. Procuraremos ajustar a nossa terminologia ao tratarmos as diferentes formas de grupalidade, bem como explicitar qual delas estamos abordando neste trabalho.

O termo "campo grupal" que está associado de forma abrangente aos fenômenos que são próprios da grupalidade ou coletividade humana, especificamente, no que diz respeito à diferenciação de ações no nível do individual, tratando das relações interpessoais e sociais dos sujeitos. Estão compreendidos no campo grupal desde as grandes massas e multidões até o grupo familiar, passando pelas instituições e os pequenos grupos, tendo cada um diferentes níveis de vinculação entre os sujeitos, que vão caracterizar as diferentes formas de coletividades. Em outras palavras, as diversas formas de os sujeitos se vincularem vão determinar um tipo de organização 
entre eles. Adotamos as definições de Anzieu (1971) na classificação que faremos a seguir, distinguindo algumas organizações que compõem o campo grupal: massa, os bandos, o agrupamento, o grupo primário e o grupo secundário.

A massa ou multidão é composta por um grande número de pessoas reunidas no mesmo lugar, sem, no entanto, haver uma combinação explícita para tal. Nesse caso, cada um busca uma satisfação individual simultaneamente, o que gera a grande concentração na qual encontramos falas do tipo "buscamos segurança", "procuramos por comida", "buscamos melhores condições de moradias", "queremos ver o Papa", entre outras. Esses encontros de massa podem ser convencionais- hora e local previamente marcados- ou espontâneos- causados por uma casualidade com reações imprevisíveis. São exemplos dessa forma de grupalidade: passeatas, manifestações políticas, torcidas de futebol, peregrinação, soldados recrutados, população revoltada contra um incidente de violência, etc. Constituem-se características dessa forma de grupalidade:

- A passividade das pessoas reunidas, no sentido de uma realização imediata de sua motivação individual;

- Ausência ou baixo nível de contato social e de relacionamento interpessoal;

- Contágio das emoções e rápida propagação para o conjunto como um todo de uma agitação surgida em um ponto;

- Estímulo latente produzido pela presença das demais pessoas em dose massiva, que pode ser um estímulo de ações coletivas passageiras, com ou sem violência.

Se uma multidão é marcada pela simultaneidade e pela solidão dos indivíduos, os bandos $^{34}$ são caracterizados pela semelhança de seus membros. Na primeira, como as pessoas estão em grande quantidade, as interações e as formas de comunicação entre elas são restritas e muito pontuais, como na estação de metrô da Sé em São Paulo às 18h, horário de muito movimento. Nessa situação, é como se as pessoas estivessem sozinhas naquela grande multidão de gente, se não fosse pelos os empurrões que são dados quando o trem pára na plataforma ou as reações no caso em que se quebrem as

${ }^{34} \mathrm{O}$ termo bando está sendo usado para designar aqueles grupos que são comumente chamados pela sociedade como tribos, pois partilham as mesmas ideologias, tendo os indivíduos os mesmos comportamentos, roupas e formas de falar. Os alunos de uma classe que são indisciplinados podem nos servir de exemplos. 
regras estabelecidas implicitamente desse coletivo humano. Já nos bandos, os indivíduos se reúnem pelo prazer de estar juntos, pela busca de pessoas que compartilham os mesmo ideais: buscam os semelhantes.

Entre os bandos, os mais comum são compostos por crianças ou adolescentes (clube da Luluzinha, clube do Bolinha, gangues, etc.), podendo ser os componentes delinqüentes ou não. Anzieu (1971), explica que os adolescentes se agregam mais facilmente dessa forma, visto que:

“(...) o prazer de formar partes dos bandos provém da superação ou da suspensão da exigência de adaptar-se, ao preço de uma tensão psíquica penosa, a um universo adulto ou social e a suas regras de pensamento e conduta" (p 25).

Essa grupalidade ainda se caracteriza pela segurança que um membro tem devido à presença do outro e do suporte afetivo de que careçam. Como estão em conjunto, a atitude de um é respaldada por outro, que só o faz porque está na presença dos seus semelhantes, ou seja, não o faria se estivesse sozinho. Encontramos situações como essas na sala de aula com alguns alunos indisciplinados que quando estão distante de seu grupo de apoio se transformam em bons estudantes.

Os bandos são caracterizados pelo número reduzido de pessoas cujas atividades que fazem em comum não são o principal objetivo, pois "fazer algo junto é uma ocasião, um meio para provar intensamente que são semelhantes" (ibid). Constitui-se ainda em um coletivo efêmero, porque a semelhança que os une pode se desfazer facilmente. No caso de um grupo de alunos de uma classe (seja os indisciplinados ou não) que se conheceram na escola, pode ser desfeito por ocasião da formatura quando cada um seguirá caminhos diferentes. No entanto, se um grupo secundário se faz durável pode se transformar em um grupo primário, que será descrito a seguir.

A forma seguinte de grupalidade é o agrupamento, que nas palavras de Anzieu (1971) ocorre "quando as pessoas se reúnem em um número pequeno, médio ou elevado, com freqüência de reuniões mais ou menos alta, com uma relativa permanência dos objetivos nos intervalos das reuniões" (p. 26).

O seu objetivo diz respeito a um interesse comum de seus membros, que podem ou não estar cientes da coletividade de interesses, pois o remetem aos dirigentes, ou seja, o interesse do dirigente é visto como o de todos. Caracterizam-se por não haver interação entre os membros fora do objetivo em torno do qual se reúnem. Dependendo 
da situação, os agrupamentos podem se aproximar ou mesmo se tornar outra forma de grupalidade, como numa multidão ou um bando.

Finalmente, o conceito de grupalidade que melhor se ajusta ao nosso trabalho diz respeito aos grupos primários ou pequenos grupos que, segundo o autor em questão, o mesmo autor, são caracterizados por:

- Número reduzido de pessoas de tal forma que possa haver uma percepção individualizada de um para com o outro;

- Uma produção de comunicação maior, tanto verbal quanto gestual;

- Busca dos objetivos de maneira mais ativa por seus membros, que são assumidos como sendo do grupo;

- As relações afetivas podem chegar a ser mais intensas (simpatias ou antipatias) e podem formar subgrupos de afinidade;

- Interdependência e sentimento de solidariedade de cooperação tanto no setting da realização dos objetivos quanto fora da reunião;

- Há uma diferenciação dos papéis entre os membros;

- Surgimento de normas, regras, crenças, signos próprios do grupo que são compartilhados pelos seus membros.

Em um grupo assim definido desenvolve-se na sua manutenção e conservação como realidade física e como imagem ideal. As condutas de progressão do grupo provocam as seguintes transformações:

- das relações entre os membros;

- da organização interna;

- do setor da realidade física ou social em que grupo está inserido (ANZIEU, 1971).

São nas transformações insistirão os terapeutas que trabalham com alguma técnica de grupo para a terapia, que pode ser estendida para grupos de ensinoaprendizagem. 
Por fim, a última forma de grupalidade que o mesmo autor nos indica é o grupo secundário, ou organização que é um "sistema social regido por instituições (econômicas, jurídicas, políticas) dentro de um segmento particular da realidade social (administrativo, comunidade científica, mercado)" (ibid, p. 30). Por organização se entende um conjunto de pessoas que cumprem finalidades específicas, complementares ou não, assemelhando-se a um agrupamento. Essas pessoas estão em uma estrutura de funcionamento que regem suas relações, determinando em certo sentido, os seus papéis e funções nessa instituição. Há um caráter mais formal nas relações dos sujeitos, podendo às vezes ser frias e impessoais. Como exemplos desses possíveis relacionamentos mencionam-se: chefe-subordinado, professor-aluno, diretor-professor, etc.

Valendo-se das figuras de linguagem, podemos lançar mão das metáforas para exemplificar o grupo primário que pode ser visto como um organismo vivo em que as relações entre os sujeitos são vistas, por analogia, como a interdependência dos tecidos e órgãos do corpo humano: o grupo será dito como um "indivíduo" composto por partes (tecidos e órgãos). Por exemplo, quando dizemos "o grupo sentiu-se abandonado pelo professor" significa que a relação entre os alunos no grupo é tal que a comunicação entre eles (verbal ou gestual) indica este estado de abandono.

Vimos então que, os coletivos humanos assumem diferentes formas que variam de acordo com a situação em que são congregados (ou se congregam). Essa diversidade é devida, sobretudo, às diferentes formações de nó (vinculação) que são geradas pelos sujeitos que ali se encontram, devido às circunstâncias. Vale ressaltar que o mais importante dessa classificação é a explicitação daquilo que entendemos por grupo, precisando a nossa terminologia e dando clareza ao que estamos tratando. Dadas essas formas de grupalidade, nos perguntamos:

"Não começaria o grupo com a presença de um terceiro em um casal ou em um par e com os fenômenos consecutivos de coesão, de rejeição, de maioria e minoria? Melhor ainda, os fenômenos de grupo não se manifestariam plenamente somente a partir de quatro membros, número a partir do qual as possibilidades de relações dois a dois superam a quantidade de membros?" (ANZIER, 1971, p.22, tradução nossa).

O que chamamos de grupo é a forma de grupalidade que se assemelha ao grupo primário. Não pretendemos, no entanto, cristalizar o nosso trabalho com as 
classificações, uma vez que se tratam de estruturas complexas, não sendo possível separá-las totalmente.

Vale ressaltar que as classificações são estruturas complexas, não sendo possível separa-las totalmente. Dessa forma, um grupo primário sempre sofre influências da instituição onde está localizado, havendo possibilidades de se transformar num agrupamento, dependendo das ações que são realizadas no seu interior, e assim por diante. 


\section{APÊNDICE III}

\section{Grupo 1-Aula $16(21 / 10 / 2004)$}

\section{1-Momentos Iniciais $(\mathbf{0 . 5 5 . 0 5})$}

Quando o grupo estava reunido para iniciar a atividade o pesquisador pediu que alguém testasse o microfone. Então, todo o grupo se mobilizou para fazê-lo e o evento foi motivo de risos entre elas, isso demonstra uma boa relação com o microfone e com o aparato de pesquisa. As alunas estavam dispostas de tal forma que uma está frente para outra e em par.

As primeiras ações do grupo foram no sentido de atribuir a funções e Carmem perguntou qual seria a dela e Rebeca lhe disse que seria a vez dela ser a Líder. Camila fez uma revisão de quem exerceu essa função nas ultimas aulas a fim de se certificar que estavam cumprindo o rodízio pedido pelo professor. Após essa verificação, Camila então confirmou a função de Líder para Carmem, para ela e Rebeca a função de Questionadoras e Eugênia como Anotadora. Rebeca ficou satisfeita com a função dela porque ela se considera "perguntadora", adjetivo que usou para si nesta aula. Na aula anterior, ela comentou algo semelhante quando foram distribuir as funções.

O professor passou pelo grupo sem permanecer com elas, não lhes falou nada e as alunas nem o notaram. Enquanto isso, elas se preparavam para iniciar a atividade, cada uma tinha o exercício consigo, pois o professor o entregou em uma folhinha separada. Porém, à medida que iam lendo os exercícios as primeiras dúvidas surgiam, e uma perguntava a outra o que era isso ou aquilo. Essa troca de informações se concentrava somente entre Camila, Rebeca e Carmem. Eugenia escrevia na folha do grupo e se comunicava com as colegas para saber seus números do diário, de modo que não interagia como as outras.

\section{2-Os primeiros embates do grupo $(0.59 .05)$}

O primeiro embate do grupo surgiu entre Rebeca e Camila, as duas questionadoras, para saber como determinava o tempo a partir da equação da velocidade, tendo a velocidade e o espaço percorrido. Rebeca afirmava que tinha que dividir um pelo outro enquanto Camila afirmava que tinha que multiplicar, e nenhuma e 
nem outra cedia. Carmem ao perceber a celeuma entre as duas perguntou o que acontecia, e Camila the formulou o problema:

Camila- Pra achar o tempo, eu vou multiplicar ou continuar dividindo?

Rebeca-Divide!

Camila- Multiplica!

Rebeca- Divide! Pra achar o tempo tem que multiplicar? Tem que dividir o espaço pela velocidade!

Camila- (não deixa Rebeca falar) Porque, ó (mostra no livro) a velocidade não é delta "S" sobre delta " $t$ ",? Para achar o delta " $t$ " não vai fazer delta " $s$ " vezes velocidade?

(ambas falam para Carmem)

Rebeca- Lógico que não, pra achar o tempo tem que multiplicar. Pede o professor que sabe de tudo (fala aproximada)

Camila- Tá me chamando de burra?

Rebeca- Não! (significando sim)

Quando Rebeca falou para pedir ao professor, o áudio não estava claro devido ao ruído da classe, mas supomos que seja aquela fala, ou pele menos com esse mesmo conteúdo, devido a reação de Camila, inferindo que Rebeca dizia que ela não sabia o que estava falando. Carmem, para quem as duas falavam, quando ouviu o que Camila disse, fez uma expressão no seu rosto dizendo que não sabia e por tanto não podia ajudá-las.

Enquanto as duas discutiam, Eugenia parou de escrever na folha do grupo, e inicialmente ficou atenta na discussão, mas em seguida se dispersou com a câmara, e mais uma vez mexeu no microfone. Nesse momento ela olhou para Rebeca, esperando ser correspondida com algum comentário sobre a filmadora, mas não obteve nenhuma resposta. Eugenia havia entrado na turma na aula anterior, sendo esta a primeira vez que fora filmada, o que significa que ela não estava acostumada ao aparato de pesquisa.

Depois da discussão entre aquelas duas alunas, o grupo ficou em silêncio cujo clima era de tensão: Camila procurava no livro algo que lhe ajudasse; Carmem não dizia nada e nem mesmo conseguia ajudar no embate; Eugenia ainda estava preocupada com os dados que tinham que ser preenchidos na folha do grupo e Rebeca não fazia nada, até mesmo porque ela era quem estava certa na discussão.

Passados alguns minutos, a dúvida ainda não estava sanada, e a relação entre Camila e Rebeca era tensa. Carmem então tentou abrandar o clima apontando na lousa aquilo que poderia ser resposta e o fim do conflito: 
Carmem- Gente olha ali, (como as duas não the ouve, chama a atenção com as mãos e fala) Ali, velocidade igual $2 \pi r$ dividido por " $t$ " ou velocidade igual a $2 \pi r$ vezes " $f$ "

Carmem disse isso para tentar apaziguar a situação, pois ela fora eleita a juíza do embate anteriormente, e pensava com isso ajudar porque havia uma operação de divisão e outra de multiplicação na fórmula para a qual apontava. Como as duas não lhe ouviram numa primeira vez, ela insistiu indicando mais uma vez as fórmulas na lousa. A dúvida não foi resolvida e tão pouco o clima entre Camila e Rebeca se modificou. Esta lhe fez uma brincadeira com pose de Camila, que estava com o dedo indicador na cabeça. Rebeca imitou a colega provocando risos no grupo e então a outra explicou que estava assim porque pensava.

Uma outra dúvida sobre o exercício foi gerada no grupo e novamente as três ficam dando idéias para tentar resolver, mas sem chegar a nenhuma conclusão. Eugenia não participava desse processo, embora não mais escrevia na folha do grupo como antes, apenas observava as outras.

\section{3-O professor no grupo (1.05.00)}

Inicialmente quando o professor se aproximou ninguém lhe falou nada e as alunas debatiam sobre como resolver essa a questão. Então, ele pegou uma cadeira que estava próxima para permanecer sentado durante a sua intervenção no grupo e a partir daí Camila começou a relatar qual era a dúvida:

Camila- A fórmula que a gente tem usar na primeira, a gente não sabe se tem que usar a fórmula da velocidade média, delta "s" sobre delta " $t$ " ou aquela ali (se refere a mesma que Carmem indicou antes e que estava na lousa)

$\mathrm{O}$ professor interagia inicialmente com Camila e Rebeca e às vezes com Carmem quando esta lhe falava alguma coisa, mas aos poucos foi abrindo canais de comunicação com as outras integrantes. Quanto a dúvida que foi a geradora de tensão no grupo não foi levada diretamente ao professor, mas na medida em que o ele ia dialogando com o grupo o tema foi aparecendo, já que o discutiam sobre frequiência e período.

Camila teve umas de suas perguntas respondidas, e quando isso ocorreu o professor lhe ofereceu um novo exemplo a fim de verificar o entendimento delas e das outras alunas. O problema era saber qual era o período de um objeto que se dá 4 voltas em 1 segundo, ou seja, qual o tempo de uma volta. As que se mostraram mais à vontade 
com o tema foram Camila e Rebeca, e esta é quem dá a idéia correta para solução: ela disse que podia resolver por regra de três. A idéia surgiu num momento de silêncio e foi interpretada por Camila como um palpite cujo seu comentário foi: "A Rebeca e os chutes dela!”. Então professor pediu que Rebeca resolvesse e ainda explicou porque podia usar esse procedimento matemático e a relação entre frequiência e período. $\mathrm{O}$ professor antes de sair do grupo sugeriu que cada uma anotasse o que Rebeca fez e o que estava na lousa.

\section{4-Idas e vindas do professor $(0.59 .05)$}

O grupo acatou a sugestão do professor e cada uma escrevia em seus cadernos o que ele acabara de explicar e o que estava escrito na lousa, e por causa disso não interagiam entre si. Mas à medida que o tempo passava, as alunas quebravam o silêncio, pois as dúvidas surgiam e uma perguntava a outra, sendo Camila era quem mais explicava para as colegas. Eugenia tinha uma participação um pouco maior em relação ao momento anterior, mas ainda não estava incluída nas discussões mais gerais do grupo.

O professor retornou ao grupo um pouco depois (1.14.08) e inicialmente o grupo relaxou com comentários divertidos do professor e das alunas. Em seguida, iniciaram a discussão, mas o professor falava mais com a Camila, e as outras os ouviam. Assim foi até o professor percebeu que Eugenia quase não participava das discussões, e lhe dirigiu a palavras:

Prof.- E você, Eugenia, né? O que elas estão falando (se refere a Camila e Rebeca)

Eugenia- Não prestei a atenção!

Prof.- Então explica de novo! (fala para Camila)

Camila- Explicar o quê?

Prof.- $O$ que você precisa para achar a velocidade?

Camila iniciou a explicação e fora auxiliada por Rebeca, as outras duas estavam atentas. Ao terminarem, o professor colocou mais uma questão ao grupo, mas dessa vez estava mais direcionado para Eugenia, tentando inclui-la no processo (e no grupo):

Prof.- Como se fa para calcular a velocidade angular?

Como ninguém lhe respondeu, ele foi detalhando as informações sobre o que ele queria, para elas percebessem onde ele queria chegar. Embora quem mais falava era 
Camila, as outras alunas procuravam em seus livros algo que lhes ajudasse na resposta, com isso demonstravam participação nesse momento.

Passado esse momento, elas partiram para a resolução do exercício, ainda com o professor no grupo, e configuração era tal que cada uma estava fazendo em seu caderno sem que interagisse entre si. Contudo, em algumas vezes, o professor lhes comentava algo para ajuda-las ou então alguém fazia uma pergunta, a qual ele não respondia diretamente forçando assim que a pergunta fosse refeita a alguém do grupo. Assim se manteve até que ele deixou o grupo (1.20.11).

As alunas permaneceram na mesma dinâmica entre elas, oscilando entre momentos de silencio, pois cada uma resolvia em seu caderno, e momentos em que trocavam perguntas sobre como se resolvia uma questão ou para confirmar uma resposta. Nas vezes em que surgiam as dúvidas, Camila era a mais solicitada e quem mais a chamava era Carmem. Com essa configuração, não era possível perceber as funções, ou seja, elas não atuavam segunda estas, sobretudo Eugenia que pouco falava e somente escrevia. A função dela era de Anotadora, mas o que ela registrava não era fruto de um processo de discussão, mas sim um processo de observação do que as outras alunas debatiam, sem a participação dela.

O professor retornou ao grupo (1.23.10) e na medida em que se aproximava dizia:

\section{Prof.- Tem alguma coisa aí que está pegando?}

Ao dizer isso, como ele se localizava mais próximo da Camila, olhou para o que ela escrevia em seu caderno e lhe disse superficialmente do que se tratava a questão. E enquanto ele verificava com Camila, as demais se atentavam para o que eles diziam e em seguida conferiam em seus cadernos o que "não estava pegando".

Mais uma vez, as alunas resolviam o seu e o professor as observava e quando surgia alguma dúvida elas interagiam entre si ou às vezes ele intervinha, mesmo sem ter sido chamado. Nas suas intervenções, ele se comunicava mais com a Camila e Rebeca, enquanto Carmem e Eugenia oscilavam entre prestar a atenção nele e resolver o seu exercício. Houve um momento em que ele pediu que todas resolvessem uma operação matemática cuja aceitação foi imediata e assim que ele solicitou, foi interrompido por alguém de outro e mais vez deixou o grupo. 
Mesmo o professor tendo saído do grupo, as alunas continuaram fazendo e como elas estavam resolvendo separadamente, era comum os momentos de silêncio. Este era quebrado nas vezes em que Rebeca e Camila trocavam informações entre si. Depois de um tempo nessa dinâmica, Carmem trouxe uma dúvida que tinha que ao pronunciá-la envolveu o grupo, com exceção de Eugenia que se manteve resolvendo o seu. Sua forma de interação com as demais era observando o que elas diziam para tentar acompanhalas. O professor então retornou ao grupo para verificar se elas estavam fazendo que o lhes pediu anteriormente. Ele verificou o caderno de Camila, fez alguns apontamentos e se retirou novamente $(1.30 .20)$

\section{5-Rebeca e Carmem falam com Eugenia (1.31.36)}

Enquanto faziam aquilo que o professor havia pedido, Rebeca pervcebeu que Eugenia estava deslocada do grupo em relação ao exercício e chamou a colega para acompanha-las na resolução. Eugenia parece que atendeu a colega de grupo e passou a interagir com grupo, dando informações importantes para a resolução do exercício. Porém, essa configuração não foi duradoura estabelecendo-se como antes: Rebeca, Camila e Carmem discutiam enquanto que Eugenia somente as observava.

O professor passou pelo grupo a pedidos de Camila, que havia encontrado uma dúvida. Assim que ele chegou ela foi falando do que se tratava e para isso contou com a ajuda da Rebeca. Ao responder, o professor o fazia mais direcionado para essas duas alunas do que para todo o grupo de forma igual. Estando o professor ainda no grupo, Carmem encontrou uma dificuldade no exercício e chamou Camila para ajuda-la. Inicialmente o professor deixou que elas tentassem, mas logo interveio. Ao fazer isso, estava mais direcionado para o lado onde estavam Carmem e Eugenia, e em seguida deixou o grupo.

Assim que o professor saiu, Carmem trouxe outra dúvida ao grupo:

Carmem- Espera aí gente! Espaço não é esse aqui? Vai dar 6,2 vezes

0,5 ?

Rebeca- Vai dar 310!

Camila- É melhor resolver!

Carmem- Não vai dar esse valor!

Rebeca nesse momento olhou para Eugenia, que parecei perdida, e então Carmem também notou a situação e como ela estava ao seu lado lhe perguntou:

Carmem-Você tá entendo o que a gente ta fazendo? 
Como Eugenia indicou que não, Carmem lhe mostrou o seu caderno e explicou para a colega tudo o que faziam. O que ela explicava era o que o professor já tinha discutido com elas momentos antes. Contudo, sua interação foi muito curta, e logo voltou a buscar explicações com a Camila, que estava a sua frente. Carmem demonstrava um certo desespero para saber o que a colega fazia, dando a entender que perdera tempo explicando para Eugenia. Esta continuou perdida no grupo, e oscilava entre tentar fazer o exercício e observar o que as demais faziam e falavam.

\section{6-Outras idas e vindas do professor (1.38.05)}

Devido ao déficit que tinha em relação à Rebeca e Camila, Carmem começou a fazer perguntas às colegas insistentemente, porém Camila lhe respondia com pouca paciência. Foi exatamente neste momento em que o professor chegou ao grupo, que sem falar nada, apenas observava como Camila procedia.

Então, ele ironizou a situação e assinalou como Camila procedia com Carmem, gerando risos no grupo. As perguntas de Carmem continuavam e o Camila agia na mesma forma:

Camila- Ai, pela décima vez, Carmem!

Prof.- Calma! Calma! (risos)

Camila- Aqui você vai transformar os valores (se refere a unidades)

Prof.- Quando acontecer de uma não conseguir fazer a outra entender, chama o professor!

Como das outras vezes, o professor interagia com mais com Rebeca e Camila, e Eugenia ainda dava indícios de que estava perdida no grupo. Nas poucas vezes em que tentava interagir era para tira alguma dúvida sobre o exercício e sempre o fazia com Rebeca ou Carmem. Não interagia verbalmente com o professor, quando esta estava no grupo nem com Camila, sendo a recíproca verdadeira para ambos.

A partir daí, o clima que se estabelece entre Camila, Rebeca e Carmem é de descontração e muita alegria, pois davam muitas risadas. Inicialmente, já sem o professor no grupo (1.41.40), essas alunas comentaram mais vez o episódio da Camila e Carmem e deram risadas sobre isso. Nem mesmo nesses momentos Eugenia interagia com elas. Em seguida, tudo era motivo de risos para aquelas alunas, seus erros, suas dúvidas, etc. 
Camila se encontrava em dúvidas novamente e chamou o professor, que logo lhe explicou e permaneceu alguns instantes no grupo. As alunas estavam alegres, e riam mesmo sem motivos aparente, envolvendo professor nesse mesmo clima. Então ele revelou a elas:

Prof.- Por isso que eu gosto desse grupo!

Carmem- É divertido!

Prof.- Sempre dá risadas, sem mesmo saber o porquê!

Carmem- (em meio a risos) Olha a fita!

Em seguida o professor saiu do grupo e ao passar perto da filmadora, pediu que elas desse um aceno para câmara, então Carmem correspondeu ao pedido. Como nas vezes anteriores, Eugenia não era envolvida no clima e nem mesmo se envolvia com as reisadas das colegas.

\section{7-Clima de alegria e momentos finais (1.46.05)}

Na sequiência, na medida em que aula se caminhava para o final o clima de alegria foi aumentando, e tudo era motivo para risos. Contudo, elas se preocupavam em com exercício e ao resolve-lo trocavam informações entre elas, com exceção de Eugenia, quem parecia estar completamente perdida em meio as colegas e quando ela percebeu que todas guardavam o material ela perguntou:

Eugenia- Acabou?

Carmem- Acabou, o resto é para casa! (fala em meio a risos)

Camila- Agora você entrega ao professor!

Camila deu este comando a Eugenia porque esta era a Anotadora, então tudo o que ela resolveu estava na folha do grupo e por tanto era para ser entregue ao professor. Para entregar,ela chamou o professor que mais uma vez sentou-se junto ao grupo e pois percebeu que havia erros na resolução. O clima ainda era de alegria e muitos risos também dele. Nesse momento final, em que Eugenia não mais estava com a folha do grupo, ela também participou das risadas, mas mesmo assim, o grupo teve que refazer algumas coisas que ficaram pendentes. 